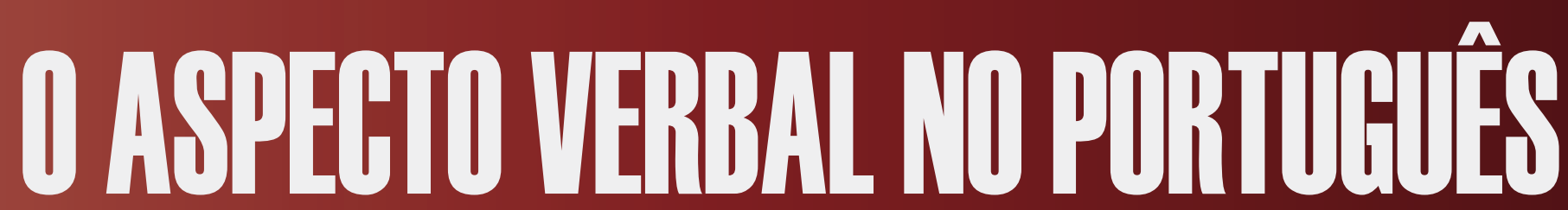 a categoria e sua expressão
}

LUIZ CARLOS TRAVAGLIA

$5^{a}$ edição 


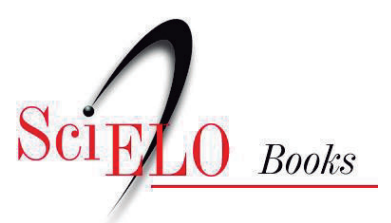

EDUFU

\title{
O aspecto verbal no Português a categoria e sua expressão
}

\author{
Luiz Carlos Travaglia
}

\section{SciELO Books / SciELO Livros / SciELO Libros}

TRAVAGLIA, L.C. O aspecto verbal no português: a categoria e sua expressão [online]. 5th ed. Uberlândia: EDUFU, 2016, 314 p. ISBN: 978-65-5824-014-3.

https://doi.org/10.7476/9786558240143.

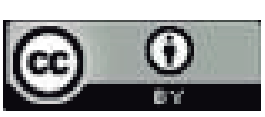

All the contents of this work, except where otherwise noted, is licensed under a Creative Commons Attribution 4.0 International license.

Todo o conteúdo deste trabalho, exceto quando houver ressalva, é publicado sob a licença Creative Commons Atribição 4.0.

Todo el contenido de esta obra, excepto donde se indique lo contrario, está bajo licencia de la licencia $\underline{\text { Creative Commons }}$ Reconocimento 4.0. 
O aspecto verbal no Português:

a categoria e sua expressão 
Luiz Carlos Travaglia

O aspecto verbal no Português a categoria e sua expressão

$5^{\mathrm{a}}$ edição

EDUFU 
(C) Luiz Carlos Travaglia, $1^{\text {a }}$ edição, 1981.

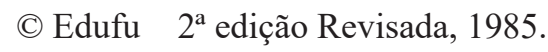

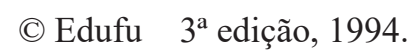

(C) Edufu $4^{\mathrm{a}}$ edição, 2006.

(C) Edufu $5^{\mathrm{a}}$ edição, 2014.

Todos os direitos desta edição reservados à Editora da Universidade Federal de Uberlândia. Nenhuma parte desta publicação pode ser reproduzida por qualquer meio sem a prévia autorização desta editora.

$\begin{aligned} & \text { Reitor } \text { Conselho Editorial } \\ & \text { Elmiro Santos Resende } \text { Adriana Pastorello Buim Arena } \\ & \text { Carlos Eugênio Pereira } \\ & \text { Vice-reitor } \text { Emerson Luiz Gelamo } \\ & \text { Fábio Figueiredo Camargo } \\ & \text { Hamilton Kikuti } \\ & \text { Diretora da Edufu } \text { Marcos Seizo Kishi } \\ & \text { Belchiolina Beatriz Fonseca } \text { Narciso Laranjeira Telles da Silva } \\ & \text { Reginaldo dos Santos Pedroso } \\ & \text { Sônia Maria dos Santos }\end{aligned}$

Equipe de realização

Editora de publicações Maria Amália Rocha

Revisão Aline Rodrigues Coelho

Revisão ABNT

Diagramação Bruno Madureira Ferreira

Capa Ivan Lima

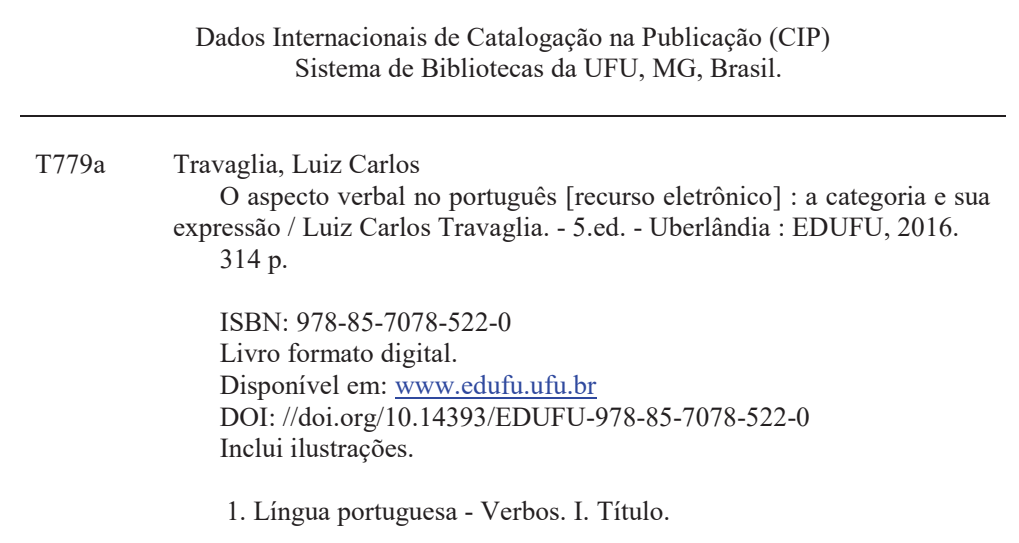

CDU: 806.90-25

Gerlaine Araujo Silva - CRB-6/1408
WUFU
Universidade
Federal de
Uberlândia

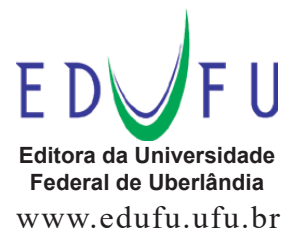
Av. João Naves de Ávila, 2121
Campus Santa Mônica - Bloco 1S
Cep 38408-100 | Uberlândia - MG
Tel: (34) 3239-4293 
à Neuza

a meus pais 


\section{SUMÁRIO}

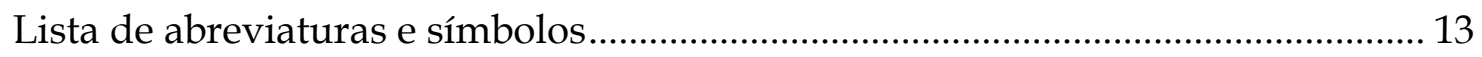

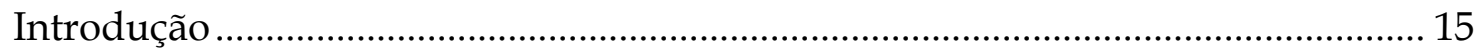

Parte I

1. - Colocações e estudos existentes sobre o aspecto no Português .......................... 19

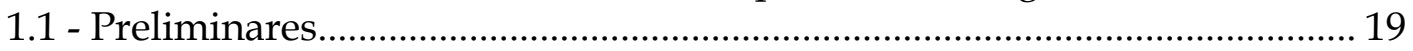

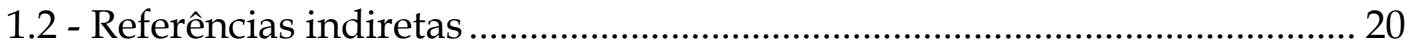

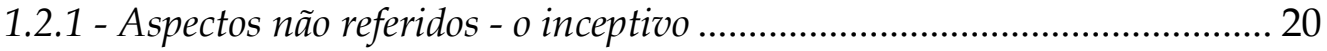

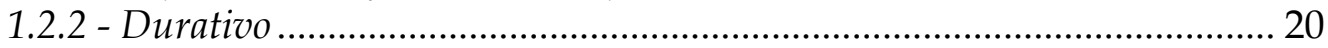

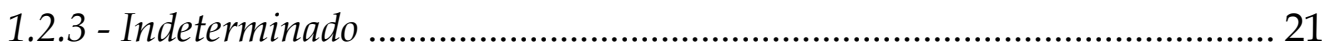

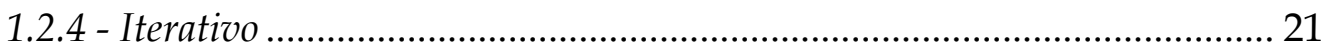

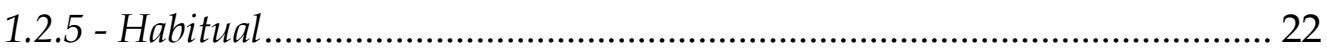

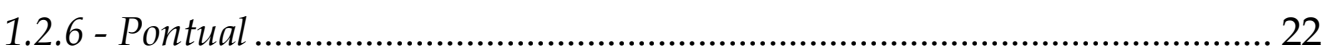

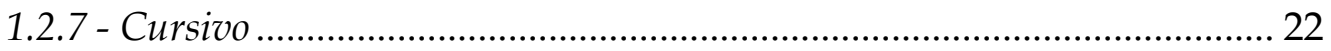

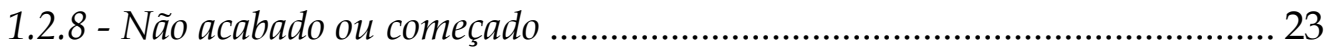

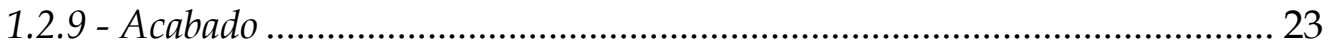

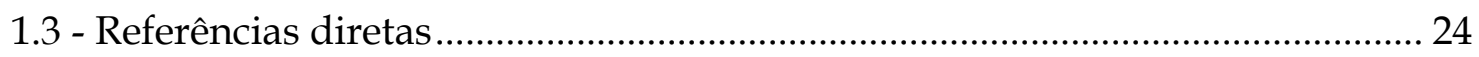

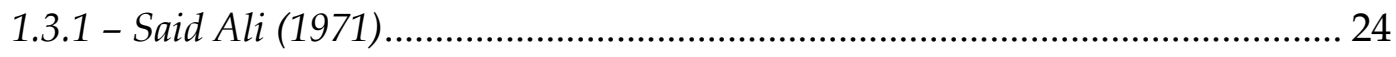

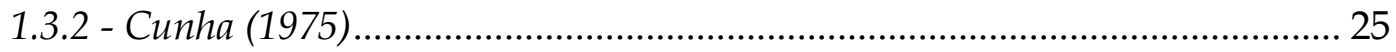

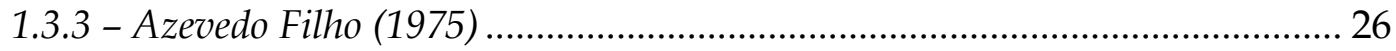

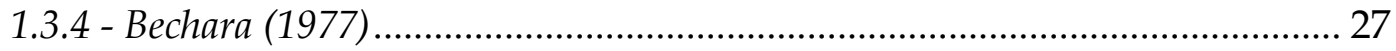

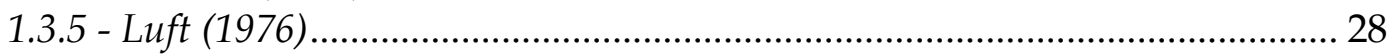

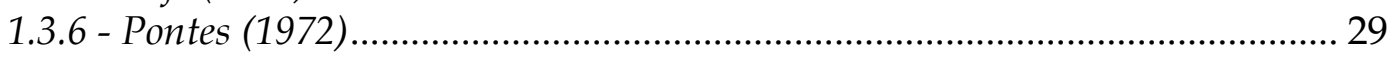

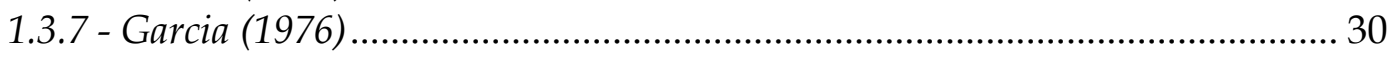

1.3.8 - Câmara Jr. (1970), Câmara Jr. (1974a, p.84-6) e

Câmara Jr. (1974b, p.140-8) ............................................................................ 32

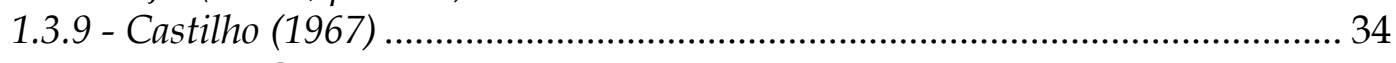

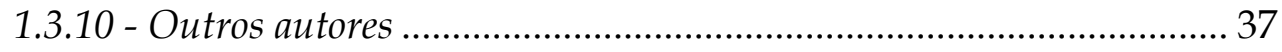

2 - O conceito de aspecto e as noções aspectuais....................................................... 39

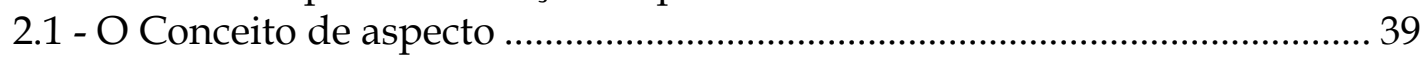

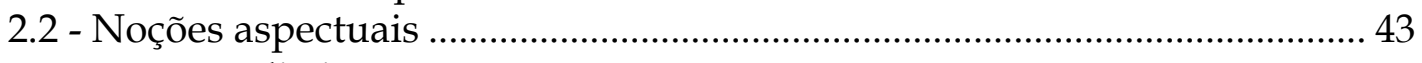

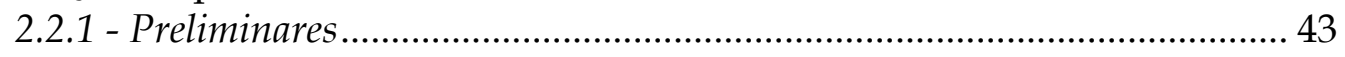

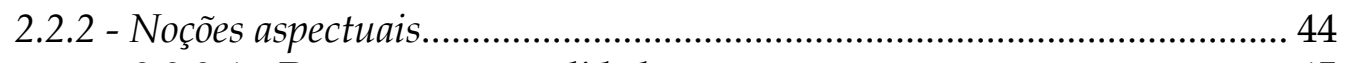

2.2.2.1 - Duração e pontualidade .......................................................... 45

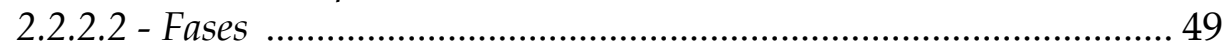

2.3 - Noções não aspectuais, mas geralmente ligadas ao aspecto ............................ 53

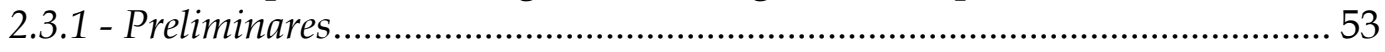

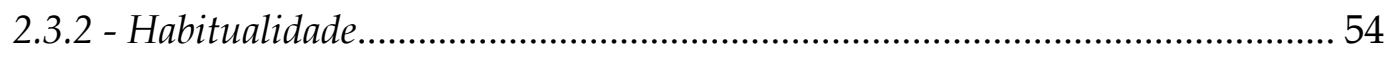

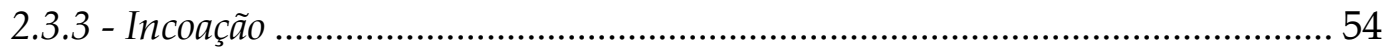


2.3.4 - Progressividade ....................................................................................... 55

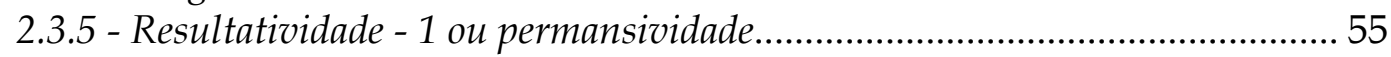

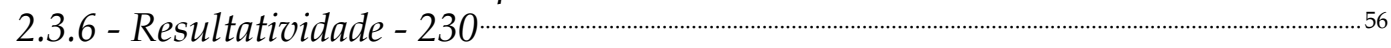

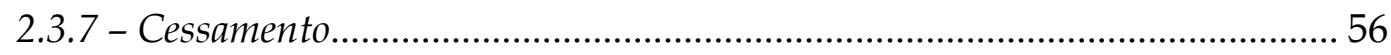

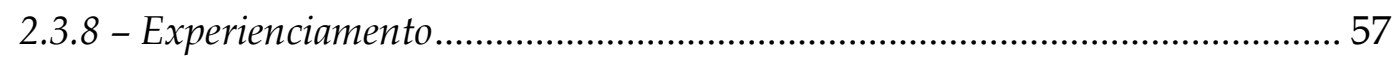

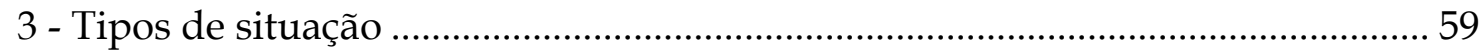

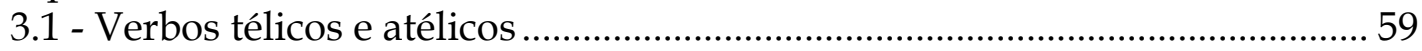

3.2 - Situação dinâmica e estática ......................................................................... 63

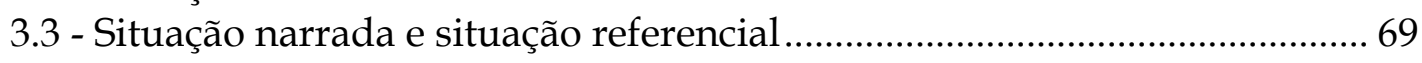

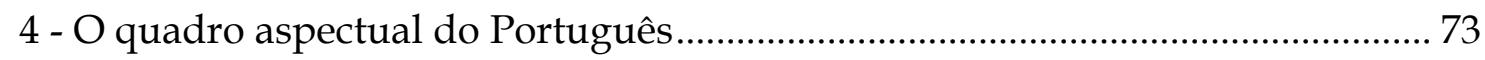

4.1 - Da impropriedade de um quadro de aspectos compostos.......................... 73

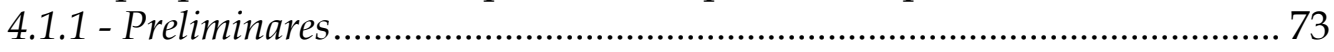

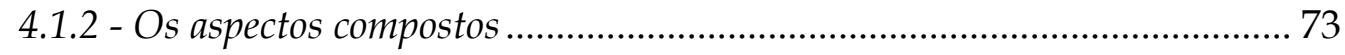

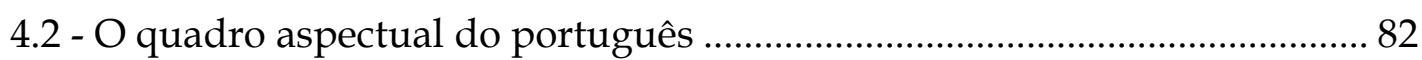

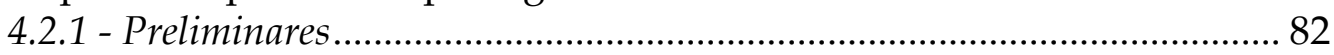

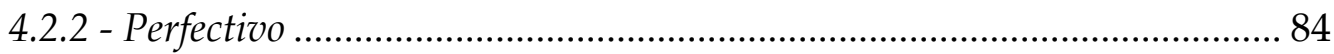

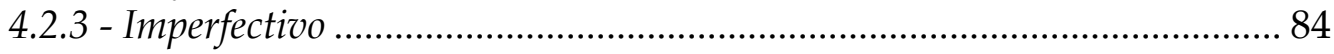

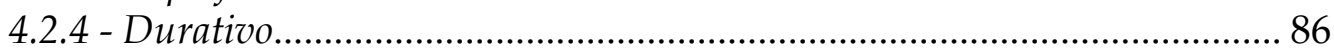

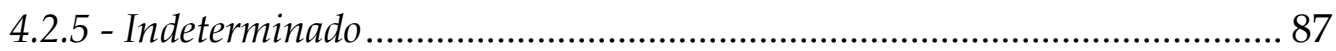

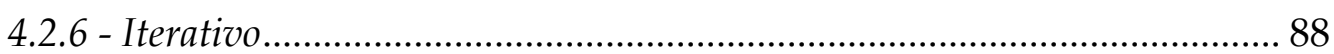

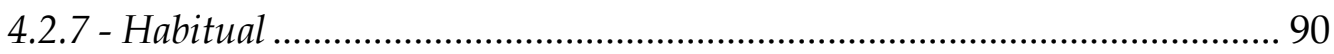

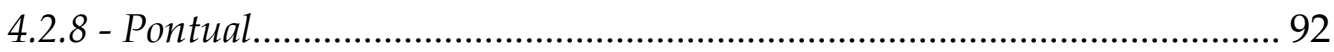

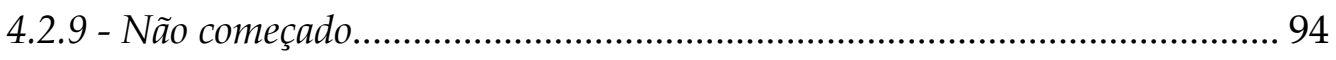

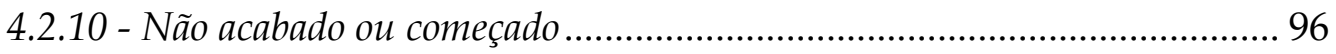

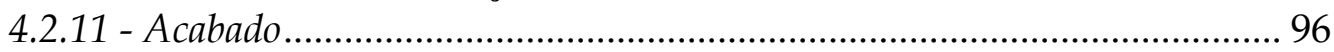

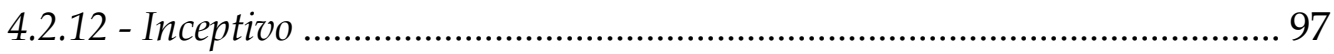

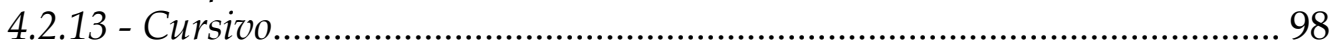

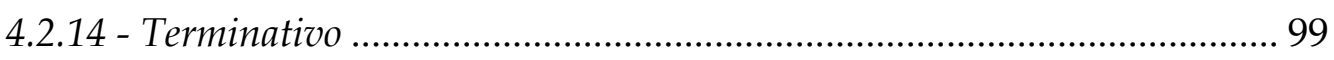

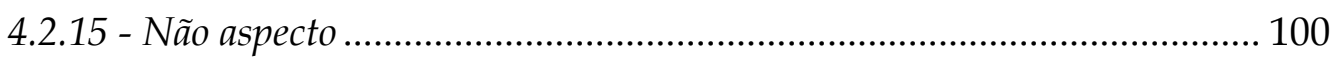

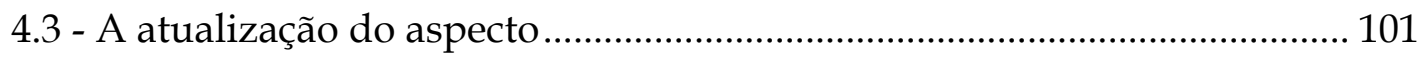

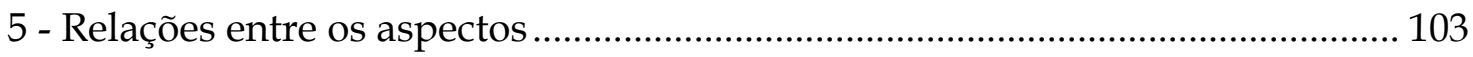

5.1 - Relações entre aspectos do mesmo grupo de distinções aspectuais ........ 103

5.2 - Relações entre aspectos de diferentes grupos de distinções aspectuais.. 104

5.2.1 - Imperfectivo e inceptivo, cursivo e terminativo........................................ 104

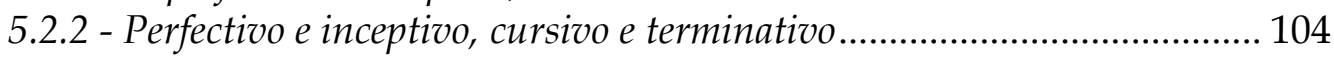

5.2.3 - Imperfectivo e não começado, começado e acabado ................................. 105

5.2.4 - Perfectivo e não começado, começado e acabado ...................................... 106

5.2.5 - Imperfectivo/perfectivo e os aspectos caracterizados pela duração e

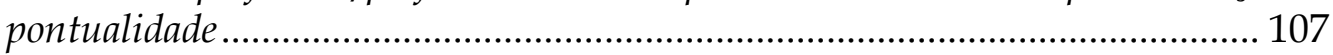

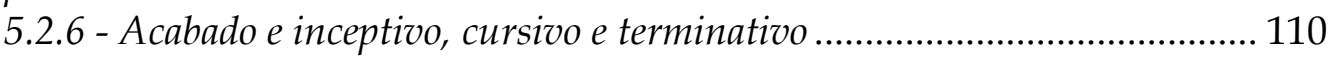

5.2.7 - Começado e inceptivo, cursivo e terminativo............................................ 111

5.2.8 - Não começado e inceptivo, cursivo e terminativo .................................... 111

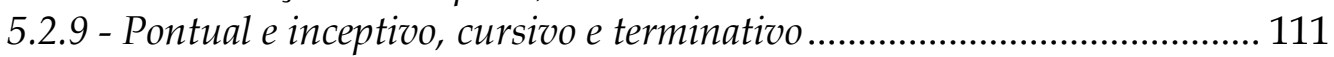

5.2.10 - Habitual e inceptivo, cursivo e terminativo............................................ 114

5.2.11 - Iterativo e inceptivo, cursivo e terminativo ............................................ 114

5.2.12 - Indeterminado e inceptivo, cursivo e terminativo ................................. 115 
5.2.13 - Durativo e inceptivo, cursivo e terminativo ..... 115

5.2.14 - Pontual e acabado, começado e não começado........................................ 116

5.2.15 - Habitual e acabado, começado e não começado ...................................... 116

5.2.16 - Iterativo e acabado, começado e não começado....................................... 118

5.2.17 - Indeterminado e acabado, começado e não começado ............................. 119

5.2.18 - Durativo e acabado, começado e não começado..................................... 120

5.3 - A distinção entre situação narrada e referencial e a análise aspectual.... 121

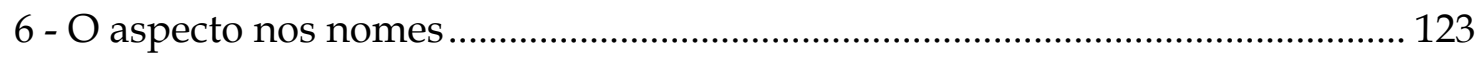

Parte II

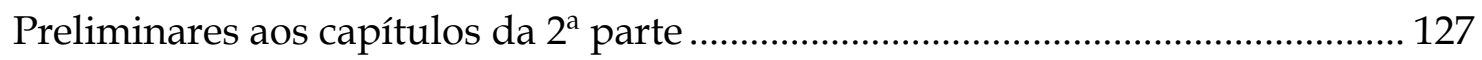

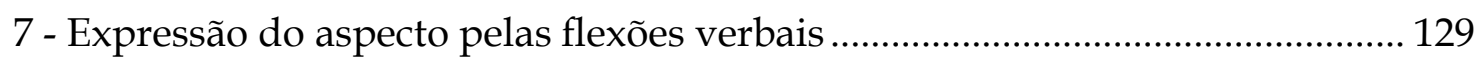

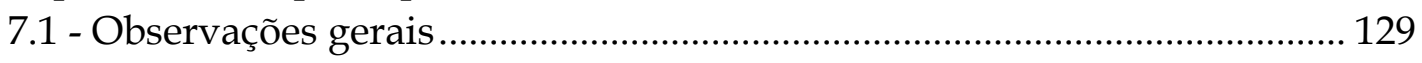

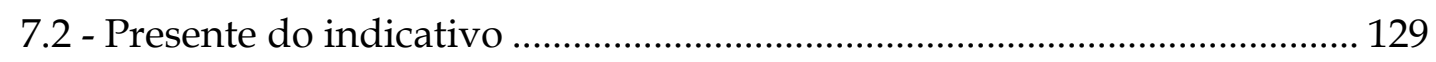

7.3 - Pretéritos imperfeito e perfeito do indicativo .............................................. 134

7.4 - Pretérito mais-que-perfeito do indicativo.................................................... 151

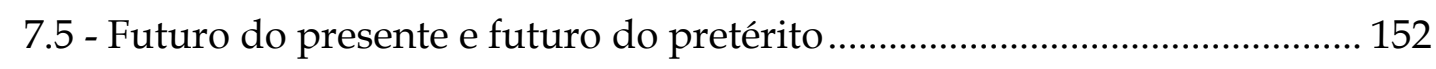

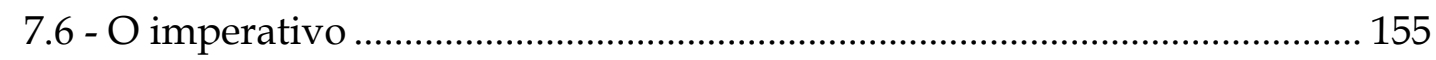

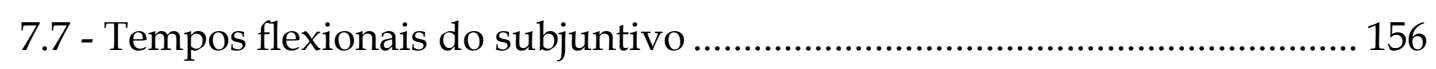

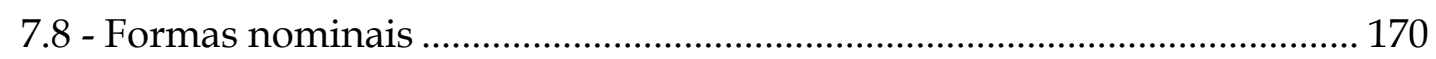

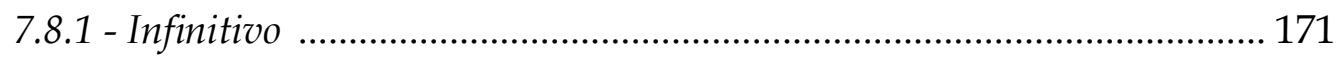

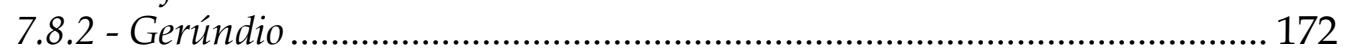

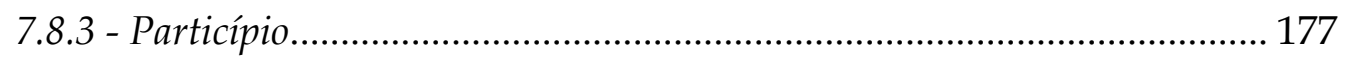

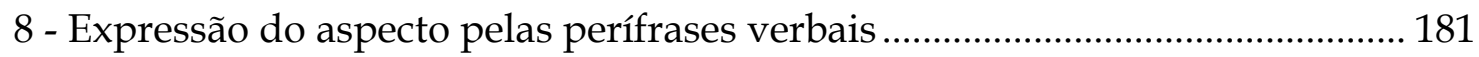

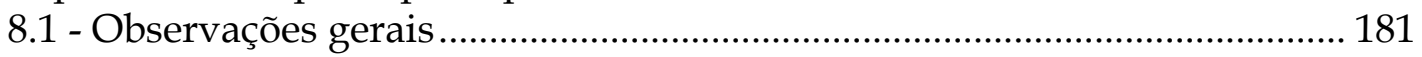

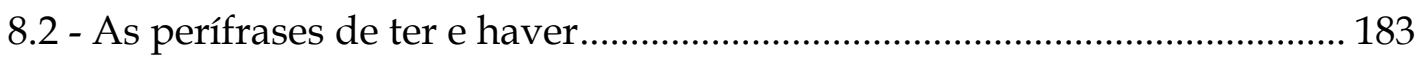

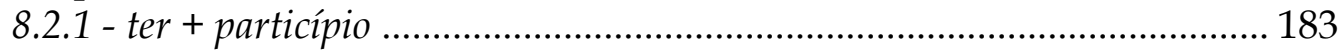

8.2.2 - haver + particípio ...................................................................... 188

8.2 .3 - ter + particípio variável .................................................................... 188

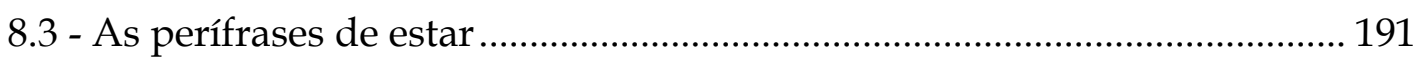

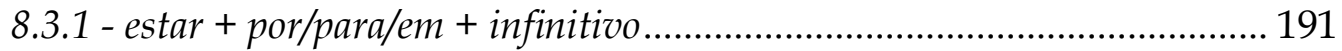

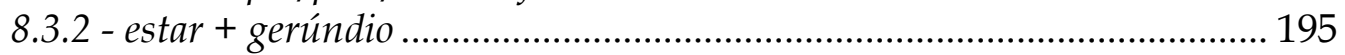

8.3 .3 - estar + particípio ............................................................................ 197

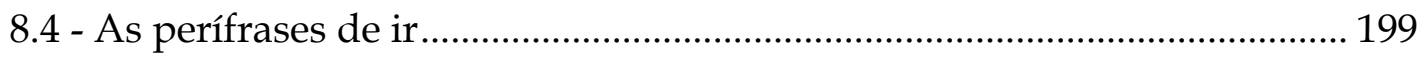

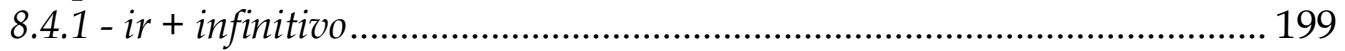

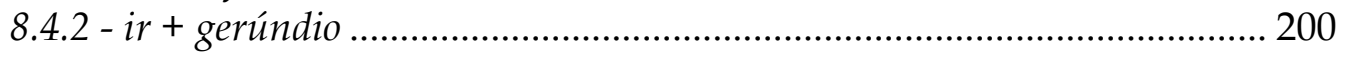

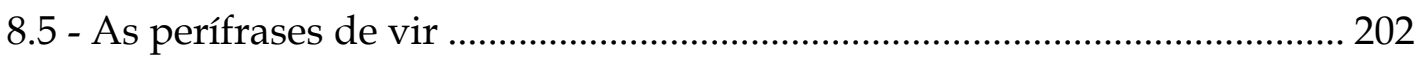

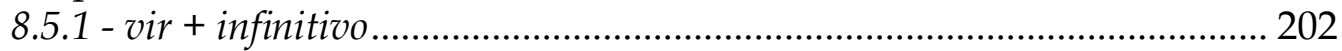

$8.5 .2-v i r+a+$ infinitivo.................................................................... 202

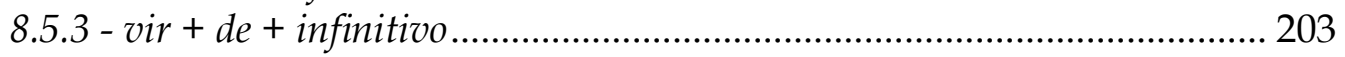

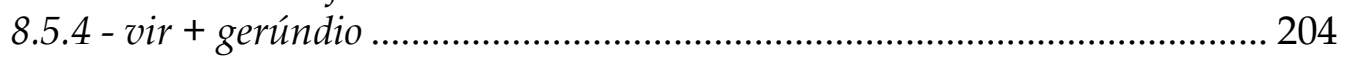

8.6 - As perífrases iterativas e habituais ............................................................. 206

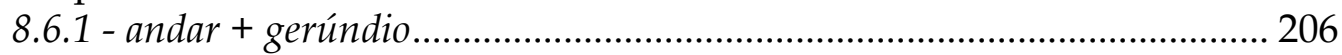

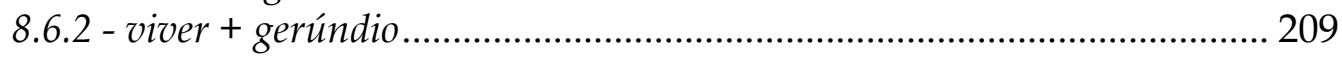




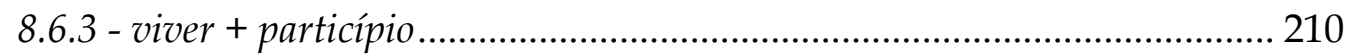

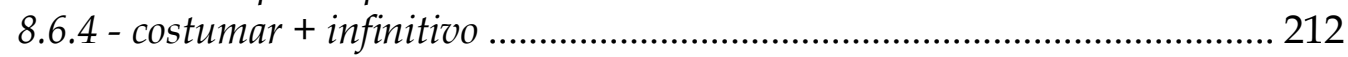

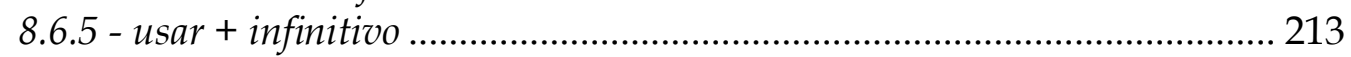

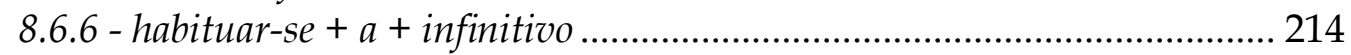

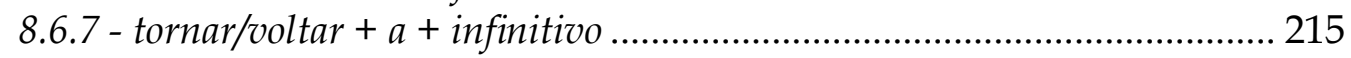

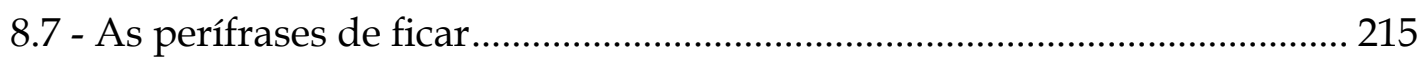

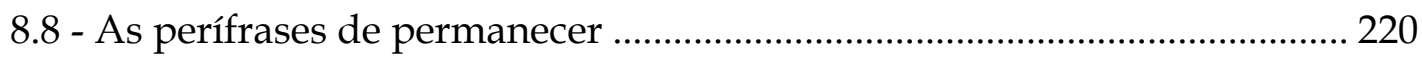

8.9 - As perífrases de continuar, prosseguir e seguir......................................... 221

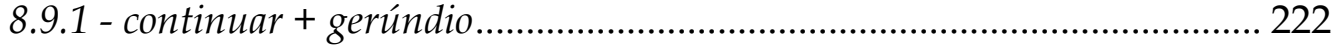

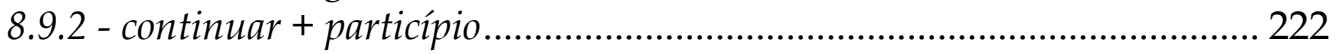

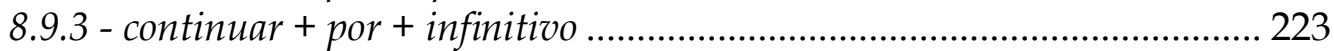

8.9.4 - prosseguir + gerúndio ................................................................... 224

8.9.5 - seguir + gerúndio ou a + infinitivo .................................................. 224

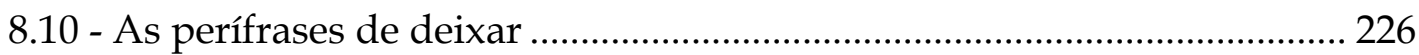

8.10 .1 - deixar + gerúndio/deixar $+a+$ infinitivo/deixar + infinitivo ............... 226

8.10 .2 - deixar + de + infinitivo ................................................................... 227

8.11 - As perífrases de cessar e parar ..................................................................... 229

8.12 - As perífrases de acabar............................................................................... 230

8.12.1 - acabar + gerúndio/acabar + por + infinitivo ...................................... 230

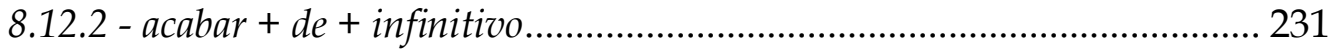

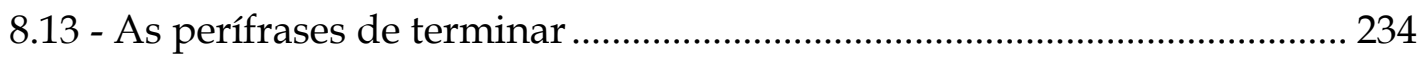

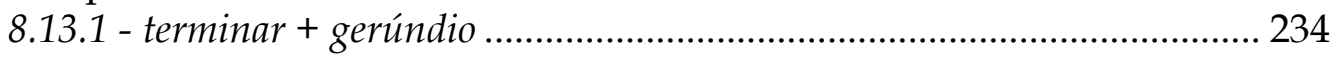

8.13 .2 - terminar + de + infinitivo ............................................................. 234

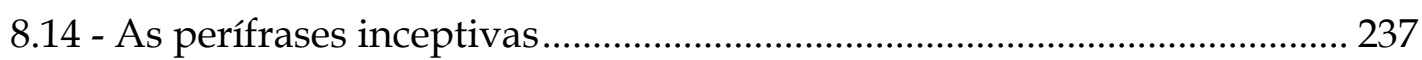

8.14.1 - As perífrases de começar e principiar ................................................. 237

8.14 .2 - A periffase de passar ......................................................................... 240

8.14 .3 - Outras perifrases inceptivas .............................................................. 242

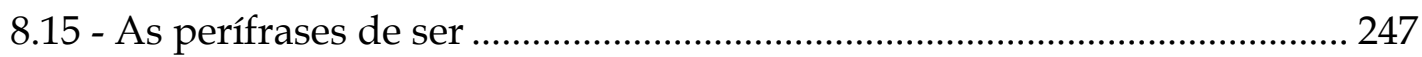

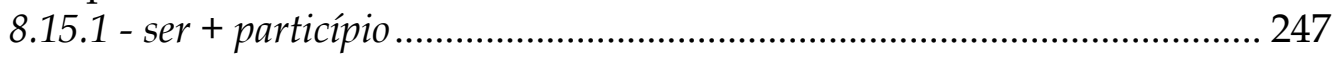

8.15 .2 - ser + particípio variável ..................................................................... 248

8.15 .3 - ser + de + infinitivo ........................................................................ 248

8.16 - Diferenças entre as perífrases que expressam o mesmo aspecto............ 249

9 - Outros recursos de expressão do aspecto ........................................................... 253

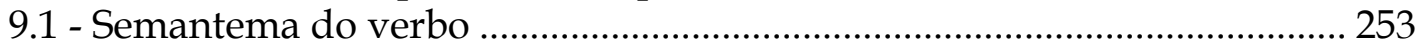

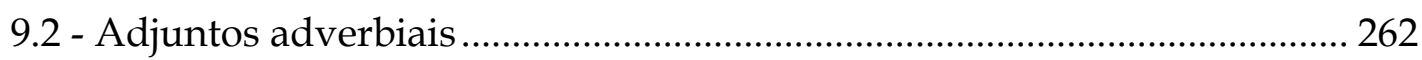

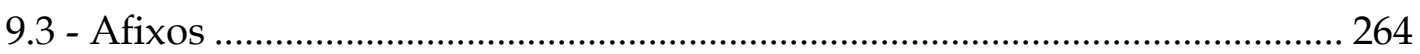

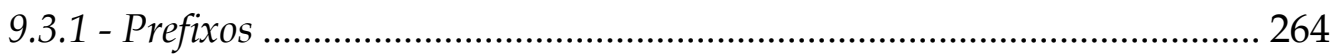

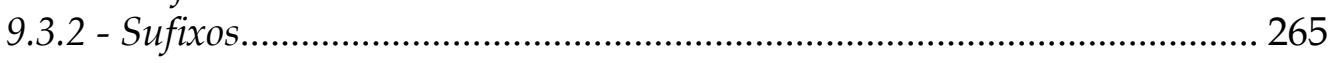

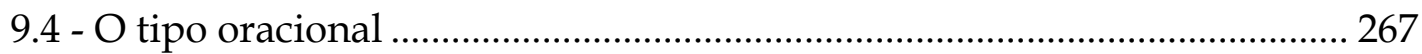

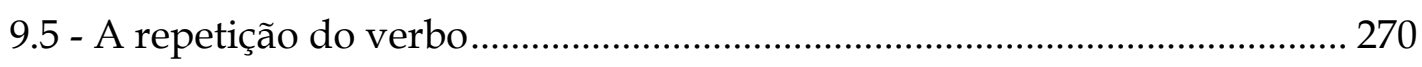

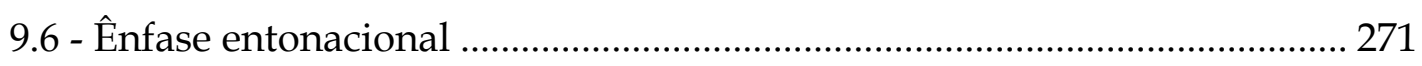

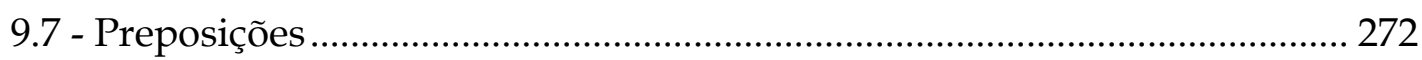

9.8 - O complemento e o sujeito do verbo ........................................................ 273 
10 - A relação do aspecto com a voz, o tempo e o modo verbal............................. 275

10.1 - Relação entre aspecto e voz ........................................................................ 275

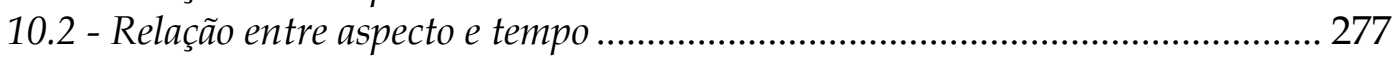

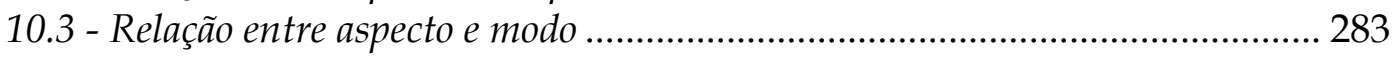

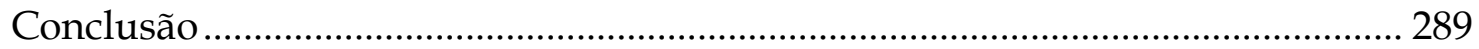

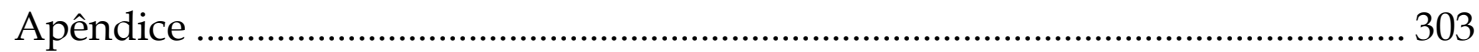

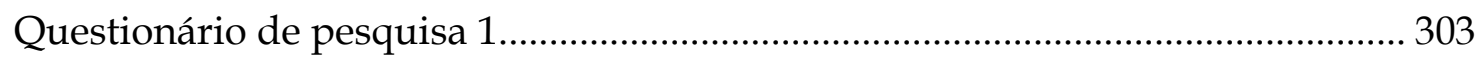

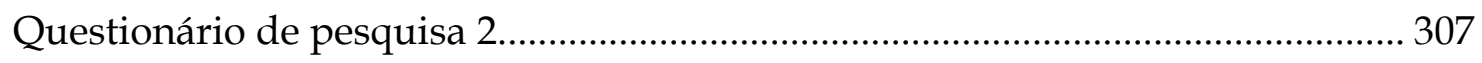

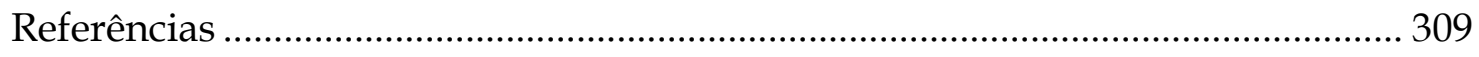

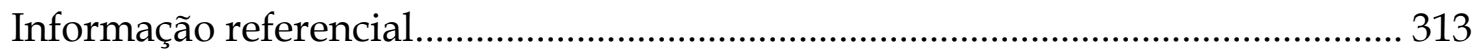




\section{LISTA DE ABREVIATURAS E SÍMBOLOS}

$\begin{array}{ll}\text { Adj. (s) } & \text { - Adjunto (s) } \\ \text { Adv. (s) } & \text { - Adverbial (adverbiais) } \\ \text { Atél. } & \text { - Atélico } \\ \text { C/ } & \text { - Com } \\ \text { Cap. (s) } & \text { - Capítulo (s) } \\ \text { Cf. } & \text { - Confronte } \\ \text { Ex. (s) } & \text { - Exemplo (s) } \\ \text { Fig. } & \text { - Figura } \\ \text { Freq. } & \text { - Frequência } \\ \text { Fut. } & \text { - Futuro } \\ \text { Imp. } & \text { - Imperfeito } \\ \text { Ind. } & \text { - Indicativo } \\ \text { Mais-q.-perf. } & \text { - Mais-que-perfeito } \\ \text { N. } & \text { - Número } \\ \text { Opos. } & \text { - Oposição } \\ \text { P. (pp). } & \text { - Página (páginas) } \\ \text { Perf. } & \text { - Perfeito } \\ \text { Pres. } & \text { - Presente } \\ \text { Pret. (s) } & \text { - Pretérito (s) } \\ \text { Subj. } & \text { - Subjuntivo } \\ \text { Tél. } & \text { - Télico } \\ \text { V. } & \text { - Ver, Veja } \\ \text { MS } & \text { - Os aspectos aparecem juntos para a mesma situação } \\ \text { MS? } & \text { - Pode-se dizer que o aspecto da horizontal aparece ao } \\ & \text { lado do da vertical para a mesma situação, mas não é } \\ \text { NJ } & \text { estritamente marcado. } \\ \text { SD } & \text { - Os aspectos não aparecem juntos em qualquer situação. } \\ & \text { - Os aspectos aparecem juntos para situações diferentes. } \\ & \end{array}$


S.N. $\quad$ - Situação narrada.

S.R. - Situação referencial.

- (No início da frase) Frase inaceitável ou agramatical

$?$

- (No início da frase) Frase estranha

$?^{*}$

- (No início da frase) Frase muito estranha, praticamente inaceitável

- Relacionamento normal entre os aspectos

- Maior tendência de relacionamento entre os aspectos

- A noção que caracteriza o aspecto da horizontal aparece bastante enfraquecida 


\section{Introdução}

No estudo do verbo no Português pouca atenção tem sido dada à categoria de aspecto (v. capítulo 1). Evidência disto é o fato de nossas gramáticas tradicionais, com raras exceções, quase não tratarem desta categoria. A sua não consideração criou uma lacuna na descrição do sistema verbal português cujo preenchimento, por si só, justifica a realização não só deste mas de muitos outros estudos sobre aspecto. Além disso a definição e descrição mais completa e exata do sistema verbal do Português fornece melhores subsídios à Linguística Aplicada na elaboração de planos e métodos para o ensino de nossa língua como língua materna e estrangeira e também nos trabalhos de tradução.

Nossos objetivos ao realizar este trabalho foram:

a. definir a categoria de aspecto;

b. estabelecer um quadro das noções aspectuais que se expressam no Português e um quadro correspondente de aspectos;

c. estudar noções semânticas que, embora não sejam aspectuais, se ligam ao aspecto de alguma forma;

d. determinar os tipos de situações indicadas pelos verbos que afetam atualização da categoria de aspecto e como o fazem;

e. determinar os meios de expressão do aspecto no Português, estudar como cada um atua e que aspectos expressa;

f. estudar a relação do aspecto com as categorias verbais de tempo, modo e voz;

g. verificar se o aspecto é uma categoria exclusivamente verbal ou se aparece também nos nomes;

h. registrar influências do aspecto na estruturação da frase, inclusive casos de agramaticalidade devidos à violação de restrições ligadas ao aspecto.

Todos estes objetivos se reúnem no objetivo geral de contribuir para a descrição do sistema verbal português.

Pela própria natureza do aspecto nosso trabalho se coloca basicamente dentro da Semântica, utilizando elementos da Sintaxe e da Morfologia e até 
da Fonologia no estudo da expressão do aspecto e da influência do mesmo na estruturação da frase.

O estudo se refere ao aspecto no Português contemporâneo do Brasil. Procuramos trabalhar dentro de uma visão de competência linguística, tentando estabelecer o todo das possibilidades aspectuais existentes no código linguístico do Português. Não nos ativemos, assim, a nenhum dialeto ou registro de qualquer dimensão. Isto, por vezes, nos deu elementos diferentes ou até mesmo contraditórios sobre um mesmo ponto o que criou dificuldades de sistematização. Quando tal aconteceu, normalmente especificamos a variante de língua em que cada fato ocorre.

Um dos grandes problemas do estudo do aspecto é a limitação do campo de trabalho. À primeira vista parece fácil fazê-lo: estudar-se-á uma categoria verbal e sua expressão. Acontece, porém, que o aspecto é uma categoria que, embora "localizada" no verbo, sofre influência dos mais diversos elementos presentes na frase e é impossível estudá-lo sem tratar de sua relação com tais elementos, o que, seguidamente, exige um estudo, . esquematização e posicionamento sobre os mesmos. No desenvolvimento deste trabalho o leitor terá oportunidade de constatar o que referimos aqui.

Outra dificuldade do estudo do aspecto se deve à sua dependência do contexto não só linguístico como também extralinguístico. A mesma frase pode ter diferentes valores aspectuais, dependendo da situação em que é utilizada ou do contexto linguístico em que se acha inserida. Assim, por exemplo, a frase: "Chove muito aqui" pode ter aspectos imperfectivo, cursivo, não acabado, durativo ou imperfectivo, não acabado, habitual conforme esteja ou não sendo usada em uma descrição simultânea (v. item 7.2). Vários casos semelhantes a este poderão ser observados no desenvolvimento do trabalho. É preciso estar atento, ainda, ao fato de que qualquer variação de significado do verbo em questão, ou na forma da frase pode acarretar modificações no aspecto atualizado; assim sendo, é preciso que o leitor esteja alerta para isto e considere que cada análise apresentada foi feita tendo em vista um conjunto de elementos que, se for alterado, pode levar a uma mudança na mesma.

Além disso, ao se estudar o aspecto atualizado em uma frase, deve-se "ver" a situação tal como é concebida pelo falante e apresentada na frase e não como é na realidade, pois se fôssemos pensar em termos de realidade jamais perceberíamos, por exemplo, que uma situação essencialmente pontual pode ser apresentada como durativa. Ruipérez ${ }^{1}$ faz alerta semelhante ao insistir "na necessidade de não mesclar sincronia e diacronia nem umas línguas e outras, e na subjetividade essencial da

${ }^{1}$ RUIPÉREZ, M. Sanchez. Estructura deI sistema de aspectos y tiempos deI verbo grieco antiguo: análisis funcional sincr6nico. Salamanca: CSIC, 1954. Apud ADRADOS (1954: 261) 
expressão linguística, que faz com que se tenha de considerar os processos sempre como são concebidos pelo falante e não como são".

Utilizamos como base estudos sobre o aspecto na Língua Portuguesa (principalmente o de Castilho (1967) que nos serviu de ponto de partida) e em outras línguas. Evitamos o reducionismo de simplesmente tentar encaixar o aspecto do Português em quadros aspectuais formulados para outras línguas, embora buscássemos verificar se fatos semelhantes ocorriam também no Português. O quadro proposto por Castilho que adotamos no início do estudo com algumas modificações foi depois substituído pelo quadro apresentado no item 4.2 pelas razões especificadas no item 4.1. Embora nossas conclusões quase sempre difiram das dos trabalhos que nos serviram de ponto de partida, só tecemos comparações quando estas se fazem estritamente necessárias. Frequentemente utilizamos exemplos extraídos de outros autores e, quando isto ocorre, especificamos no texto ou em nota. O uso de tais exemplos, entretanto, não significa que os trabalhos de onde foram tirados estejam falando sobre eles o mesmo que nós. Muitas vezes nem de aspecto eles estão tratando.

Para chegar aos resultados aqui expostos trabalhamos com um método misto de Onomasiologia e Semasiologia principalmente no estudo da expressão do aspecto. A Onomasiologia deve ser entendida aqui como o seguinte: tendo um determinado significado (no caso uma noção aspectual) buscam-se as formas linguísticas pelas quais ele pode ser expresso e as construções frasais em que ele está presente. Já a Semasiologia é o processo inverso: dada uma forma busca-se saber quais os significados (no caso quais as noções aspectuais) que ela pode expressar ou que podem estar presentes nela.

A partir de um quadro prévio buscamos analisar o maior número possível de exemplos. Esse quadro foi sendo reformulado à medida que se mostrava insuficiente para a análise aspectual das frases portuguesas e cada novo quadro era retestado em nova bateria de exemplos até chegarmos ao quadro aspectual do Português apresentado no item 4.2. No estudo da expressão dos aspectos verificávamos tanto que aspectos cada recurso podia expressar, bem como que recursos podiam expressar determinado aspecto. Cada tipo de frase era modificado através de substituições e/ou acréscimos de elementos formando o maior número de variações possíveis o que nos permitia verificar não só a ação de um dado meio na expressão do aspecto, mas também a ação conjunta de diferentes elementos que atuam na expressão do mesmo. Assim, por exemplo, construímos frases com o preso do indo de verbos indicadores de diferentes tipos de situações (v. capítulo 3), com ou sem adjuntos adverbiais, etc.; para verificar como este tempo flexional agia relativamente à expressão do aspecto com diferentes tipos de situações, e assim com cada flexão 
verbal. No estudo da expressão do aspecto pelas perífrases, para um outro exemplo, construímos nada menos de 4.700 frases a fim de verificar a atualização do aspecto feita pelas mesmas nas diferentes flexões verbais, nos diferentes modos, com a ação de adjuntos adverbiais e tipos oracionais e sem a ação destes; enfim dentro do maior número possível de variações frasais. Este método de trabalho se mostrou extremamente eficiente e profícuo fazendo com que inúmeros fatos relativos ao aspecto e sua expressão no Português pudessem ser observados.

Finalmente, vejamos algo sobre a estrutura do trabalho. Ele é constituído de duas partes. A primeira coloca o estado atual dos estudos sobre o aspecto no Português, conceitua aspecto, estabelece quais são as noções aspectuais, o correspondente quadro de aspectos e as relações possíveis entre os mesmos. Além disso, refere-se ao problema dos aspectos nos nomes, trata de várias noções semânticas não aspectuais, mas normalmente ligadas ao aspecto e fala dos tipos de situações cuja consideração normalmente é pertinente na análise aspectual. A segunda parte trata da expressão do aspecto e de sua relação com as categorias verbais de voz, modo e tempo. 


\section{Parte I}

\section{1 - Colocações e estudos existentes sobre o aspecto no Português}

\section{1 - Preliminares}

Para iniciar este trabalho julgamos pertinente fazer uma exposição ligeira do levantamento feito do que já se disse sobre a categoria do aspecto no Português. O que encontramos foi pouco, embora tenhamos encontrado pelo menos um trabalho de porte como é o de Castilho (1967).

Parece-nos válido expor aqui a síntese do que pudemos encontrar dito por vários estudiosos da Língua Portuguesa sobre a categoria de aspecto, já que isto nos serviu de ponto de partida e para que se tenha uma visão do que se disse e como se disse. Muitas vezes o que temos é uma superposição ao Português de quadros aspectuais criados por estudiosos de outras línguas, quase sempre não se define com clareza a categoria ou as noções enquadradas dentro dela que, com frequência, são simplesmente nomeadas.

Nas referências a aspecto que encontramos nos estudiosos podemos separar dois tipos:

a. Diretas: quando o autor fala explicitamente em aspecto, buscando conceituar a categoria, apresentar um quadro aspectual e, por vezes, especificar as formas de expressão da categoria;

b. Indiretas: quando o autor não se refere à categoria de aspecto, mas, ao estudar determinados fatos da língua, se refere a noções que, como se verá, são nitidamente aspectuais. Esse tipo de referência aparece principalmente quando os autores estão tratando do emprego dos tempos e modos verbais ou do valor das perífrases e verbos auxiliares. São, portanto, referências descaracterizadas. 
Passemos, pois, à exposição do que encontramos sobre o aspecto em Língua Portuguesa, esclarecendo ainda que, para facilidade de exposição e compreensão, agrupamos as referências indiretas pelo quadro aspectual que proporemos como final neste trabalho.

\section{2 - REFERÊNCIAS INDIRETAS}

\subsection{1 - ASPECTOS NÃO REFERIDOS - O INCEPTIVO}

Primeiramente convém observar que não há referências indiretas aos aspectos que em nosso quadro aspectual chamaremos de perfectivo, imperfectivo, terminativo e não começado.

Dias (1970, p.187-188 e p.247-248) faz uma referência indireta ao aspecto que chamaremos de inceptivo, quando diz que as perífrases no pretérito imperfeito do indicativo são usadas para falar de uma ação na qual só se deu o primeiro passo, significando que a ação começou mas não se realizou. Embora haja a referência à noção aspectual, como se poderá ver na parte relativa às perífrases no capítulo sobre a expressão do aspecto, a perífrase referida não exprime inceptividade nem no pretérito imperfeito do indicativo nem em outro tempo qualquer.

Referências indiretas podem ainda ser encontradas em relação aos aspectos que chamaremos de:

\subsection{2 - Durativo}

Said Ali (1971, p.310-322) e Said Ali (1964, p.161-162) se refere a este aspecto ao dizer que o presente do indicativo e principalmente o pretérito imperfeito denota ação durativa. É o mesmo que faz Bechara (1977, p.274) ao afirmar que o pretérito imperfeito do indicativo é o tempo da ação prolongada e Cunha $\left(1975\right.$, p.436) ${ }^{1}$, que ao diferenciá-lo do pretérito perfeito também diz que exprime ação durativa. Cunha (1975) ainda se refere indiretamente ao aspecto durativo, quando às páginas 380 e 382 fala do valor das perífrases ANDAR ou ESTAR ou FICAR + GERÚNDIO e quando, à página 463, diz que o gerúndio expressa uma ação durativa. Também Bechara (1977, p.274), ao dizer que o pretérito perfeito composto indica prolongamento de um fato até o momento em que se fala, e Dias (1970, p.274), ao dizer que as perífrases representam a ação como objeto de ocu-

\footnotetext{
${ }^{1}$ Consultamos não apenas Cunha (1975), mas também Cunha (1972), entretanto, como não há diferenças entre as duas obras, fazemos a citação apenas pela mais recente delas.
} 
pação prolongada, se referem indiretamente ao aspecto aqui tratado. Said Ali (196, p.183) diz que as perífrases de IR ou VIR + GERÚNDIO são usadas para significar melhor a duração do fato.

\subsection{3 - INDETERMINADO}

Said Ali (1971, p.310), Said Ali (1964, p.161) e Cunha (1975, p.430), quando falam sobre uso do presente que intitulam "presente durativo" e Dias (1970, p.184), quando fala do "presente Universal" que designa o que se dá em todo o tempo, estão indiretamente falando do que chamaremos de aspecto indeterminado. Também o fazem Cunha (1975, p.433), quando diz que o pretérito imperfeito do indicativo é usado "para designar fatos passados concebidos como contínuos ou permanentes", e Dias (1970), quando diz, à página 187, que o pretérito imperfeito do indicativo é usado para indicar genealogia e qualidades de um indivíduo ou que pode ser usado no lugar do presente universal em orações subordinadas a um pretérito; às páginas 188 e 189, quando diz que o pretérito perfeito do indicativo pode substituir o presente universal ${ }^{2}$ e às páginas 195 e 196, quando diz que se usa o futuro do pretérito para falar de uma coisa que pertence a todo o tempo.

\subsection{4 - ITERATIVO:}

O presente do indicativo e o pretérito imperfeito do indicativo são dados como tempos que apresentam o processo verbal como algo que se repete por Said Ali (1971, p.310-22), Said Ali (1964, p.161-162) (presente frequentativo), Bechara (1977, p.274) (só se refere ao pretérito imperfeito) e Dias (1970, p.184) (presente iterativo). Bechara (1977, p.274), Dias (1970, p.189) e Cunha (1975, p.435) dizem que o pretérito perfeito composto (presente do indicativo de TER + PARTICÍPIO) exprime a repetição de um fato, de uma ação até o momento presente. Cunha (1975) ainda se refere ao aspecto interativo à página 379 ao falar do valor das perífrases TER ou HAVER + PARTICÍPIO e à página 436, quando diz que o pretérito perfeito do indicativo só pode indicar iteração com o auxílio de adjuntos adverbiais. Said Ali (1964, p.183) diz que a perífrase ANDAR + GERÚNDIO é usada para significar melhor a repetição do fato.

\footnotetext{
${ }^{2}$ Não concordamos com isso, pois a nosso ver o pretérito perfeito do indicativo não pode expressar o aspecto indeterminado, mas antes serve para nos referirmos a uma aplicação específica do que é aplicável a todos os tempos ou é tido como uma verdade.
} 


\subsection{5 - HABITUAL}

Referência indireta ao aspecto habitual é feita por Said Ali (1971, p.310-22), Said Ali (1964, p.161-2) (presente frequentativo), Cunha (1975, p. 430, 432-3, 436) (presente do indicativo e pretérito imperfeito do indicativo habitual ou frequentativo), Bechara (1977, p.273) e Dias (1970, p.184) (presente iterativo), quando dizem que o presente do indicativo e o pretérito imperfeito do indicativo indicam, expressam um fato, uma ação que é costume, que acontece habitualmente. Bechara (1977, p.274) ainda se refere ao habitual ao dizer que o pretérito perfeito composto indica fato habitual.

\subsection{6 - PONTUAL}

Referência indireta ao aspecto que chamaremos de pontual só encontramos em Cunha (1975, p.436), quando na distinção b entre pretérito imperfeito e pretérito perfeito do indicativo, ele diz que o segundo expressa ação momentânea e em Dias (1970, p.188), quando diz que o pretérito perfeito apresenta os acontecimentos que se deram considerados como simples momentos históricos (perfeito histórico).

\subsection{7 - CURSIVO}

Ao falar do emprego e do valor do presente do indicativo, vários autores se referem indiretamente ao aspecto cursivo, quando dizem que este tempo enuncia ou expressa o fato, a ação como ocorrendo no momento em que se fala ou que tendo começado no passado se prolonga até o momento em que se fala. Estão neste caso: Said Ali (1971, p.310), Said Ali (1964, p.161), Cunha (1975, p.429) (presente momentâneo), Bechara (1977, p.273) e Dias (1970, p.183-184). Dias ainda esclarece que para indicar o que está se dando no momento em que se fala sem confusão com o que costuma acontecer devem-se usar, no presente do indicativo, as perífrases "estar + particípio presente (gerúndio) ou a + infinitivo". Said Ali (1971, p.160 § 819) também alude ao valor cursivo das perífrases acima e atribui o mesmo valor à perífrase "ir + gerúndio.

Cunha (1975, p.432) e Dias (1970, p.185-6) aludem ao que chamaremos de aspecto cursivo, quando dizem que, com o pretérito imperfeito do indicativo, expressamos o que se estava processando no passado, quando sobreveio outra ação ou fato; ou expressamos o que tendo começado, continuava ainda no tempo em que se deu um fato. Mais uma vez Dias (1970) observa que para expressar esta noção sem confusão com o que costumava acontecer é preciso usar a conjugação perifrástica acima referida no pretérito imperfeito do indicativo Cunha (1975, p.457 e 461) diz que o gerúndio apresenta o processo verbal em curso. 
Dias (1970) ainda se refere indiretamente ao aspecto cursivo em duas passagens: às páginas 186 e 187, quando diz que se usa o pretérito imperfeito do indicativo dos verbos "dicendi" em vez do pretérito perfeito do indicativo para representar o leitor ou o ouvinte como assistindo ao seguimento do discurso, e à página 189 , quando diz que o pretérito perfeito composto (para ele pretérito perfeito indefinido) exprime a continuação de uma ação desde certo momento até o momento em que falamos.

\subsection{8 - NÃO ACABADO OU COMEÇADO}

Cunha (1975, p.432 e 434) se refere a este aspecto ao dizer que o pretérito imperfeito do indicativo expressa fato passado mas não concluído, inacabado.

Bechara (1977, p.274) e Dias (1970, p.192 e 248) fazem referência ao aspecto começado ao dizer que as perífrases expressam de modo preciso a ação como começada.

\subsection{9 - ACABADO}

Cunha (1975, p.435) e Dias (1970, p.189) (pretérito absoluto) se referem indiretamente ao aspecto acabado, quando dizem que o pretérito perfeito do indicativo exprime uma ação concluída, um fato consumado.

Para Cunha (1975, p.464-465) e Said Ali (1971, p.159 § 809) o particípio encerra a noção definidora do aspecto acabado, uma vez que, para eles, essa forma nominal exprime o resultado de uma ação acabada o que levou vários autores a falarem em aspecto resultativo (ou permansivo). Já Dias (1970, p.246) diz que o particípio indica uma ação pretérita (= acabada, nesta passagem).

Cunha (1975, p.379 e 440 e ss.), Bechara (1977, p.111) e Dias (1970, p.1945) afirmam que os chamados tempos compostos (TER ou HAVER + PARTICÍPIO) exprimem a ação como acabada, concluída. Câmara Jr. (1974b, p.143) registra que Said Ali em Dificuldades da Língua Portuguesa afirma que estas formas indicam a "realização perfeita" (isto é conclusa) "até o presente, ou até determinado momento do passado ou do futuro".

Dias (1970, p.250) ainda se refere ao aspecto acabado, quando diz que SER + PARTICÍPIO passivo de verbos intransitivos ou tomados em sentido intransitivo é empregado para exprimir um ato consumado como em (1).

1. Somos chegados. 
Como se pode ver, não são poucas as referências feitas a noções aspectuais por autores que, às vezes, nem mesmo aludem diretamente à existência de uma categoria verbal de aspecto. Isto serve para demonstrar a importância do aspecto na semântica da frase, pois, mesmo sem referir explicitamente a existência da categoria, os estudiosos da língua comentam o uso de formas verbais em função desta categoria nas suas manifestações mais patentes pela frequência ou força semântica.

Passemos agora às referências diretas.

\section{3 - REFERÊNCIAS DIRETAS}

Fazem referência direta à categoria de aspecto os seguintes estudiosos da Língua Portuguesa:

$$
\text { 1.3.1 - SAID ALI (1971) }
$$

Nesta seção, falando de conjugação composta, Said Ali utiliza a palavra aspecto e fala de aspecto imperfectivo para se referir à conjugação simples e de aspecto perfectivo para se referir à conjugação composta com o verbo auxiliar TER e verbo principal no particípio. Parece-nos, pois, que estes termos estão se referindo mais à forma de conjugação do que a alguma noção semântica que defina uma categoria verbal ou alguma subdivisão desta categoria.

Em nenhum momento Said Ali define o que está chamando de aspecto, mas não cremos que com este termo ele esteja se referindo à categoria verbal objeto deste trabalho, uma vez que além de falar dos aspectos imperfectivo e perfectivo ele fala também de aspectos que nada têm a ver com a categoria verbal em questão, tais como o aspecto passivo para referir-se à conjugação de voz passiva (ser + particípio) e o aspecto necessitativo que semanticamente envolve uma modalidade (de necessidade, obrigação) para identificar a conjugação perifrástica TER+DE+INFINITIVO. Este autor fala ainda do aspecto do momento rigoroso, referindo-se à conjugação de ESTAR + GERÚNDIO, que ele diz ser a enunciação da "ação como se passando rigorosamente no momento em que se fala (presente) ou de que se fala (pretérito ou futuro)". Esta definição do aspecto do momento rigoroso é, possivelmente, uma das melhores definições que se poderia dar do que chamaremos de aspecto cursivo.

Pelo que Said Ali diz no parágrafo 831, ao introduzir o quadro da página 163 , vê-se claramente que ele não está falando da categoria verbal que nos propomos

\footnotetext{
${ }^{3}$ p. $161-3, \S \S 822$ a 831.
} 
estudar aqui, mas se refere apenas a tipos de "conjugação simples" e de "conjugação composta", aludindo a noções aspectuais que as perífrases comentadas expressam, como é natural ocorrer quando se fala do valor de tais perífrases.

Outro elemento que nos permite afirmar que Said Ali está preocupado em rotular apenas elementos formais é o fato de ele colocar, por exemplo, em seu quadro da página 63, no "aspecto imperfectivo", formas que reconhecidamente marcam o que chamaremos de aspecto perfectivo tais como o pretérito perfeito e o pretérito mais-que-perfeito do indicativo, o que só ocorre em consequência de estar ele preocupado apenas com a forma.

\subsection{2 - CUNHA $(1975)^{4}$}

À página 380, Celso Cunha diz que alguns verbos são usados como auxiliares para "indicar matizes de tempo ou para marcar certos aspectos do desenvolvimento da ação" tais como a progressividade, o firme propósito de realizar algo ou o resultado final da ação. ${ }^{5}$ Pelos aspectos do desenvolvimento anotados percebemos que Celso Cunha usa o termo "aspecto" num sentido geral e não no sentido especializado da categoria verbal objeto deste estudo.

À página 457, ao falar do valor do infinitivo e do gerúndio composto, Cunha apresenta o seguinte quadro:

\begin{tabular}{c|c|c}
\hline & $\begin{array}{c}\text { ASPECTO } \\
\text { NÃO CONCLUíDo }\end{array}$ & $\begin{array}{c}\text { ASPECTO } \\
\text { CONCLUÍDO }\end{array}$ \\
\hline Infinitivo & Escrever & Ter escrito \\
\hline Gerúndio & Escrevendo & Tendo escrito \\
\hline
\end{tabular}

Neste quadro o autor fala outra vez de aspecto e agora com referência a noções que estão entre aquelas que reputamos como pertencentes à categoria de aspecto: não concluído/concluído, que se identificam com os aspectos que chamaremos de não acabado/acabado. Também à página 463, ao falar do valor do gerúndio, diz que esta forma nominal tem aspecto inacabado, referindo-se, mais uma vez, a noção enquadrada na categoria de aspecto.

Ainda à página 463, Cunha diz que o gerúndio se combina com os verbos estar, andar, ir e vir para marcar diferentes aspectos da execução do processo

\footnotetext{
${ }^{4}$ Ver nota 2.

${ }^{5}$ Como veremos mais adiante, progressividade, firme propósito de realizar algo ou resultado final da ação não são aspectos de acordo com a definição que daremos da categoria.
} 
verbal e se refere a aspectos tais como do momento rigoroso, intensificação, reiteração, progressividade, progressividade até o momento presente, o que, como veremos, inclui elementos não aspectuais (progressividade, intensificação), levando-nos mais uma vez a pensar que o autor está usando o termo aspecto não no sentido específico de uma categoria verbal, mas num sentido geral. Outro elemento que nos leva a pensar assim é o fato do autor apresentar a duração das ações expressas pelo gerúndio (que como veremos é uma noção aspectual) à parte do que ele chama de aspecto.

Como se vê, Cunha se refere diretamente a aspecto, mas não o trata como uma categoria verbal, não busca conceituar aspecto ou estabelecer um quadro aspectual, definindo os aspectos. O que temos é uma utilização do termo aspecto sem qualquer preocupação de sistematizar algo sobre o assunto, sendo quase certo que o autor utilizou a palavra "aspecto" sem estar pensando na categoria que tem este nome.

\subsection{3 - AzEVEDo FiLHo (1975)}

Azevedo Filho, às páginas 63 e 64, define o aspecto como sendo "a duração do processo verbal ou o prisma sob o qual ele é apreciado". Como se pode ver, a segunda parte da definição ("o prisma sob o qual ele é apreciado") é muito vaga.

Este autor apresenta o seguinte quadro aspectual: "designando a duração, o processo verbal pode ser momentâneo ou durativo". Designando o aspecto propriamente dito, pode ser incoativo (começo de ação) em seu curso e inconcluso (aspecto inconcluso ou imperfeito) em seu fim já concluso (aspecto concluso ou perfeito), concluso, mas permanente em seus efeitos (aspectos permansivo). Fala ainda de aspecto frequentativo e de aspecto de ação iminente. Este último, como veremos, é uma noção temporal e não aspectual. $\mathrm{O}$ autor apresenta poucos exemplos.

Quanto aos meios de expressão do aspecto, reunindo o que o autor diz às páginas 63 e 64 e às páginas 79 e 86 , quando fala do emprego dos tempos e modos, temos o seguinte: $\mathrm{o}$ aspecto pode ser expresso pelos tempos verbais ou por locuções verbais em que figuram auxiliares chamados aspectuais. Em síntese tem-se: 


\begin{tabular}{l|l}
\hline ASPECTO & MEIO DE EXPRESSÃo \\
\hline Momentâneo & Presente do indicativo \\
\hline Durativo & $\begin{array}{l}\text { Presente do indicativo, pretérito imperfeito do indicativo (duração, } \\
\text { tempo linha), estar }+ \text { gerúndio. }\end{array}$ \\
\hline Incoativo & $\begin{array}{l}\text { Presente do indicativo (o único exemplo dado é de um verbo inco- } \\
\text { ativo: amanhecer), começar }+ \text { a }+\end{array}$ \\
\hline Inconcluso & Pretérito imperfeito do indicativo. \\
\hline Concluso & $\begin{array}{l}\text { Pretérito perfeito do indicativo, pretérito mais-que-perfeito do } \\
\text { indicativo, acabar }+ \text { de }+ \text { infinitivo. }\end{array}$ \\
\hline Permansivo & Pretérito perfeito composto do indicativo, presente do indicativo. ${ }^{6}$ \\
\hline Frequentativo & Presente do indicativo, costumar + infinitivo. \\
\hline Habitual & Presente do indicativo, pretérito imperfeito do indicativo. \\
\hline De ação iminente & Ir + infinitivo \\
\hline
\end{tabular}

O próprio autor reconhece que o assunto comporta discussão mais ampla e remete para o trabalho de Castilho (1967) que, como facilmente se poderá notar, difere do que apresenta Azevedo Filho já pelo quadro de aspectos.

\subsection{4 - BECHARA (1977)}

À página 110, Bechara diz que "muitas vezes o auxiliar empresta um matiz semântico ao verbo principal dando origem aos chamados aspectos do verbo".

À página 111, comentando as aplicações dos verbos auxiliares no Português, diz que os chamados "tempos compostos" formados de ter, haver (raramente) ou ser (mais raramente) exprimem que a ação verbal está concluída. Entretanto parece não apresentar o "concluído" como um aspecto do verbo, pois logo adiante à página 111 fala dos auxiliares acurativos que "se combinam com o infinitivo ou gerúndio do verbo principal para determinar com mais rigor os aspectos do momento da ação verbal que não se acham bem definidos na divisão geral de tempo presente, passado e futuro" (grifo nosso).

Entre esses aspectos do momento da ação apresenta os seguintes:

a. Início de ação: começar a escrever, pôr-se a escrever, etc.;

b. Iminência de ação: estar para (por) escrever, etc.;

c. Desenvolvimento gradual da ação, duração: estar a escrever, andar escrevendo, vir escrevendo, ir escrevendo;

\footnotetext{
${ }^{6}$ Os exemplos dados: "Tens estudado muito" e "O Sol é uma estrela" nada têm de permansivo (cf. definição dada) e, como veremos, estas formas não marcam o permansivo.
} 
d. Repetição da ação: tornar a escrever, costumar escrever (repetição habitual), etc.;

e. Término de ação: acabar de escrever, cessar de escrever, deixar de escrever, parar de escrever, vir de escrever, etc.

Como se pode ver, nem todas as noções que são colocadas, tais como as de e e d acima, podem, propriamente, ser chamadas de momentos da ação verbal. Observa-se também que não há uma definição de aspecto, a não ser indiretamente, ao dizer que são aspectos do momento da ação verbal o que nos leva mais para a categoria de tempo do que para o que chamaremos de aspecto.

\subsection{5 - LuFT (1976)}

À página 131, Luft define aspecto como "a categoria verbal que exprime a oposição término/não término ou acabado/não acabado, a duração do processo" e, à página 124, diz que o aspecto seria a categoria através da qual se exprimem as noções temporais de "início, duração, ou resultado de um processo". Evidentemente o resultado não é uma noção temporal e dizer que o aspecto exprime "noções temporais" pode causar maiores confusões entre aspecto e tempo que muitas vezes são confundidos principalmente por serem muito interligados. Luft não apresenta um quadro aspectual e os exemplos que apresenta são da oposição acabado/não acabado.

Para Luft o aspecto é expresso: a) em conjunto com o tempo: cantei/canto, cantara/cantava (= acabado/não acabado); b) por locução verbal: estava cantando / tem cantado (o autor não especifica qual a oposição aspectual aqui). À página 136, Luft diz que as locuções verbais podem exprimir aspectos do processo: anterioridade, posterioridade, continuidade, repetição, progressão, início, conclusão, etc.; entretanto não diz que locuções exprimem estes "aspectos" e nem deixa claro se a palavra aspecto aqui foi usada no sentido definido à página 131 ou não, já que as noções arroladas não se enquadram na definição de aspecto que ele dá; c) por sufixos: - ec(er) incoativo: enriquecer, -ej(ar), -it(ar) iterativos: voejar, saltitar; d) pelo próprio radical verbal com sua significação característica (andar, parar, etc.). Neste último caso o autor não especifica qual o aspecto expresso.

Como se pode ver não se trata de um estudo mais detalhado sobre o aspecto, mas apenas uma referência que não deixa muito claro o que seja a categoria de aspecto, nem quais são os aspectos possíveis em nossa língua, nem quando cada um está presente, comentário, aliás, válido para a maioria dos trabalhos que se referem diretamente ao aspecto no Português, exceção feita ao trabalho de Castilho (1967). 


\subsection{6 - PonTes (1972)}

Às páginas $80 \mathrm{e} 84$, Pontes apresenta um conceito de aspecto tirado de $\mathrm{Nida}^{7}$ e que é muito pouco esclarecedor, pois é muito pouco relacionado com o quadro de noções aspectuais que apresenta: aspecto seria "a maneira de ser da ação".

As noções aspectuais que apresenta são duas:

a. Durativa, linear, prolongada: indica ação que se prolonga no tempo;

b. Pontual, não linear: indica ação que se realizou num período de tempo mais determinado, não prolongado.

Estudando qual das duas noções as formas verbais expressam no Português coloquial, Pontes constrói os seguintes quadros:

\begin{tabular}{c|c|c|c|c}
\hline \multirow{2}{*}{} & \multicolumn{2}{|c|}{ LINEAR } & \multicolumn{2}{c}{ NÃO LINEAR } \\
\cline { 2 - 5 } & Passado & Não passado & Passado & Não passado \\
\hline $\begin{array}{c}\text { Indicativo } \\
\text { (real) }\end{array}$ & $\begin{array}{c}\text { Lavava } \\
\text { (Pretérito } \\
\text { imperfeito) }\end{array}$ & $\begin{array}{c}\text { Lavo } \\
\text { (Presente) }\end{array}$ & $\begin{array}{c}\text { Lavei } \\
\text { (Pretérito } \\
\text { perfeito) }\end{array}$ & \\
\hline $\begin{array}{c}\text { Subjuntivo } \\
\text { (irreal) }\end{array}$ & & Lave & $\begin{array}{c}\text { Lavasse } \\
\text { (Pretérito } \\
\text { imperfeito) }\end{array}$ & $\begin{array}{c}\text { Lavar } \\
\text { (Futuro) }\end{array}$ \\
\hline & & (Presente) & \multicolumn{2}{c}{ NEUTRO } \\
\hline $\begin{array}{c}\text { Formas } \\
\text { Nominais }\end{array}$ & Lavando & Lavado & \multicolumn{2}{c}{$\begin{array}{c}\text { Lavar } \\
\text { (Infinitivo) }\end{array}$} \\
\hline
\end{tabular}

Pontes ainda aponta o fato de haver uma seleção de formas adverbiais em função da noção aspectual presente no verbo:

a. linear: expressões adverbiais indicadoras de frequência e hábito;

b. não linear: expressões que limitam a frequência e o hábito ou que precisam um período de tempo mais marcado.

As expressões de tempo determinado com formas não lineares referem-se a um período de tempo definido, enquanto que com formas lineares não se restringem a um período de tempo definido, elas fogem a qualquer pontualidade.

${ }^{7}$ NIDA, Eugene A. Morphology - The descriptive analysis of, 2. ed. Ann Arbor: The University of Michigan Press, 1949, p.167. 
Como se vê, Pontes, talvez pelos próprios limites que impôs ao seu trabalho, não diz muito sobre o aspecto.

\subsection{7 - GARCia (1976)}

Às páginas 58 a 65, Garcia fala diretamente da categoria de aspecto definindo-a como "a representação mental que o sujeito falante faz do processo verbal com duração" (grifo nosso). Essa definição calcada em Vendryes ${ }^{8}$, embora incompleta, não apresenta a falha de apontar para elementos não aspectuais, mas a seguir Garcia diz que o aspecto "é a modalidade de ação, a sua maneira de ser, que não se deve confundir com o modo verbal propriamente dito (indicativo, imperativo, etc.)", confundindo, por definição, o aspecto com a categoria de modalidade e com noções semânticas que nada têm a ver com categorias verbais, como bem se pode observar na listagem de aspectos por ele apresentada.

Quanto à expressão do aspecto, Garcia esclarece que este não tem no Português formas e flexões próprias como o tempo, o que não significa que o aspecto seja menos importante que o tempo, como poderia parecer. Garcia anota ainda que por não possuir no quadro de sua conjugação verbal formas exclusivas para indicar o aspecto, o Português utiliza construções subsidiárias, como as perífrases, para expressar o aspecto ou utiliza "certos utensílios gramaticais adequados a esse mister" que, entretanto, ele não diz quais são.

Entre as noções aspectuais e aspectos expressos por perífrase que ele apresenta, muitos nada têm a ver com aspecto, estando mais ligados à modalidade ou então são apenas noções semânticas que não se ligam a categorias verbais. Neste caso estão a causação (aspecto causativo ou factivo); a obrigação, o compromisso e a necessidade, a volição (aspecto desiderativo, volitativo ou intencional); a permissão; a possibilidade e a capacidade (aspecto potencial); a conação (aspecto conativo); a iminência (aspecto iminente); o resultado (aspecto resultativo). Ao falar de "tonalidades aspectuais nos tempos simples e compostos", Garcia afirma que os tempos simples e compostos aparecem, às vezes, claramente ou levemente matizados de aspecto, mas que nem sempre é fácil saber se se trata realmente de aspecto ou de diferentes acepções da mesma forma temporal e apresenta vários itens, dizendo que podem referir-se a aspecto ou a tempo, o que não importaria muito distinguir, não esclarecendo, pois, o que pertenceria a aspecto e o que pertenceria a tempo. Todavia podemos desde já dizer que não são aspectuais as seguintes noções ou usos: ação próxima e decidida, promessa ou ameaça, maior realce para fatos

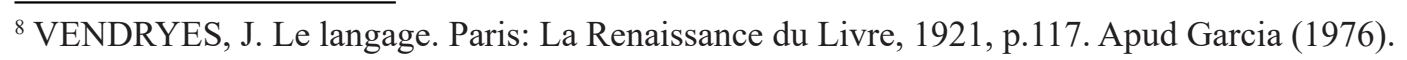


passados, citação (para presente do indicativo); simultaneidade, concomitância, futuro do pretérito, vontade ou desejo, em discurso indireto implícito (para o pretérito imperfeito do indicativo); probabilidade, incerteza, cálculo aproximado, hipótese, observância a preceitos ou normas, ordem atenuada, pedido ou sugestão, eventual, deliberativo (para o futuro do presente); desejo e esperança (para o pretérito mais-que-perfeito do indicativo).

Considerando o fato de os tempos apresentarem tantos matizes semânticos sob a camada da mesma desinência temporal, Garcia propõe falar-se em tempos-aspectos, embora insista em dizer que tempo é uma coisa e aspecto outra.

Dentre as noções que apresenta podem ser consideradas verdadeiramente aspectuais as seguintes:

a. Duração (decurso, frequência) define aqui o aspecto durativo que frisa a duração ou continuidade do processo, da ação. Subdivide o durativo em progressivo (que em realidade não é um aspecto como já dissemos), quando a ação intensifica-se cada vez mais e cursivo, quando a ação se desenvolve simplesmente. Caracteriza o gerúndio e o pretérito imperfeito do indicativo como formas típicas do aspecto durativo que também é expresso pelas perífrases "estar / andar / viver / continuar / ficar + gerúndio ou a+infinitivo";

b. Iteração (repetição) que seria um aspecto variante do de duração normalmente expresso por perífrases tais como "tornar / voltar $+\mathrm{a}+$ infinitivo" ou pelo prefixo RE- (reler, retransmitir);

c. Incoação: tem-se aqui o aspecto incoativo ou inceptivo definido pela ideia de ação iniciada mas ainda não concluída. É expresso pelas perífrases "começar a (ou seu equivalente) + infinitivo" ou pelos sufixos -ecer, -escer;

d. Cessação ou terminação: tem-se aqui o aspecto cessativo ou concluso segundo Brugmann ${ }^{9}$ ou efectivo, perfectivo ou transicional segundo Gray ${ }^{10}$ que apresenta a ação como terminada. É expresso pelas perífrases "acabar / terminar / cessar / vir + de + infinitivo".

Como vemos, o perfectivo está sendo colocado como acabado, terminado.

\footnotetext{
${ }^{9}$ BRUGMANN, Karl. Abrége de grammaire comparée des langues indo européennes. Trad. fr. de J. Bloch. Paris: Klincksieck, 1905, p.521-3. Apud Garcia. (1976, p.61).

${ }^{10}$ GRAY, Louis H. Foundations of language. New York: Macmillan, 1939, p.207. Apud Garcia (1976, p.61).
} 
e. Habitualidade ou Frequência com o presente do indicativo ou o pretérito imperfeito do indicativo (imperfeito habitual). Ao falar de presente universal ou acronístico e em futuro gnômico ou proverbial, que indicam fatos habituais perenes, doutrina firmada, conceitos filosóficos ou morais, verdades de ordem geral, Garcia faz referência ao que chamaremos de aspecto indeterminado.

Como se pode ver, Garcia, embora traga contribuições ao estudo do aspecto no Português, não apresenta uma definição abrangente da categoria nem um quadro aspectual coerente internamente e nem com a definição dada de aspecto e confunde aspecto e modalidade.

1.3.8 - CÂMARA JR. (1970), CÂMARA JR. (1974A, P.84-6) E CÂMARA JR. (1974B, Р.140-8)

Câmara Jr. define o aspecto como "a propriedade que tem uma forma verbal de designar a duração do processo (momentâneo ou durativo) ou o aspecto propriamente dito sob que ele é considerado pelo falante (Exemplo: em seu começo - incoativo)". Diz ainda que o aspecto é a maneira de ser da ação e que apresenta o processo verbal do ponto de vista da sua duração.

Reunindo o que ele diz em diferentes passagens podemos dizer que ele apresenta o seguinte quadro aspectual, sem qualquer dúvida calcado no proposto por Brugmann (ver nota 10):

a. aspecto inceptivo ou incoativo: indica a ação que principia, a ação em seu começo, marca o princípio de um processo;

b. aspecto inconcluso ou imperfeito: apresenta a ação que se desdobra sem alusão ao início ou ao fim, a ação em seu curso e ainda inconclusa;

c. aspecto concluso ou cessativo ou perfeito: apresenta a ação que termina, acabada, em seu fim e já conclusa, marca o fim de um processo;

d. aspecto permansivo: apresenta o processo como concluso, mas permanente, persistente em seus efeitos, à maneira de uma coisa adquirida;

e. aspecto resultativo: registra os resultados de um processo realizado;

f. aspecto pontual ou momentâneo: assinala um processo realizado de maneira súbita e instantânea;

g. aspecto durativo: frisa a duração do processo. Subdivide-se em: g.1 - progressivo: é o durativo em que o processo se intensifica cada vez mais; 
g. 2 -cursivo: é o durativo em que o processo se desenrola simplesmente; g.3 - frequentativo ou iterativo: é o durativo em que o processo se repete por uma série de processos pontuais.

Segundo Câmara Jr. o aspecto pode ser expresso:

1. pelo semantema do verbo. Exs.: partir (inceptivo ou incoativo), chegar (concluso ou cessativo), cair (pontual), andar (durativo), andar, viajar (inconcluso);

2. por sufixos. Exs.: -ITAR, -EJAR (frequentativo); -ECER(incoativo);

3. pela conjugação verbal:

A - tempos verbais: presente do indicativo (iterativo); pretérito imperfeito do indicativo (inconcluso ou imperfeito); pretérito perfeito (concluso ou perfeito), embora Câmara Jr. (1970, p.90) afirme que o pretérito perfeito é indiferente à assinalização de aspecto concluso ou inconcluso.

$B$ - perífrases:

a. Cursivo (no presente, passado e futuro) e durativo (em qualquer tempo): "estar + gerúndio ou a + infinitivo", "ir + gerúndio (durativo progressivo);

b. Cessativo (concluso, realização perfeita):

- TER ou HAVER + PARTICÍPIO: Essa perífrase expressa o cessativo em todos os tempos exceto no presente do indicativo onde assinala um fato constante (contínuo ou repetido) até o momento presente ou esporadicamente um aspecto permansivo (Exemplo: "A areia tem corrido e o livro de minha infanda história está completo"- Varela, Obras, II, 38). Pode-se afirmar que o uso permansivo desta perífrase inexiste hoje, pelo menos no Português do Brasil.

- SER + PARTICÍPIO (de verbo intransitivo). Exs.:

2. “Já cinco sóis eram passados" (Lusíadas, V-37)

3. "Meu Deus, meu Deus, pois a isto somos chegados!" (Cf. Boléo, 1936) $)^{11}$

c) Inceptivo: "ir + infinitivo".

\footnotetext{
${ }^{11}$ Exs. apud. Câmara Jr. (1974a, p.86).
} 
O próprio Câmara Jr. diz que com esta perífrase o processo se apresenta como prestes a começar, portanto não pode ser, como se verá, marcadora de aspecto inceptivo.

$\mathrm{C}$ - formas nominais: o gerúndio indica o aspecto inconcluso ou imperfeito e o particípio o aspecto concluso ou perfeito.

4. pela repetição do verbo. Exemplo: "cai, cai, balão, na rua do Sabão..." (aspecto durativo).

As referências de Câmara Jr. a aspecto, embora das mais bem estruturadas, não deixam tudo claro, pois, por exemplo, o que seriam os "aspectos propriamente ditos" a que ele se refere na definição apresentada?

\subsection{9 - CASTILHo (1967)}

O trabalho de Castilho é, sem qualquer dúvida, o trabalho mais completo sobre o aspecto no Português e um dos poucos que se dedicam ao estudo apenas desta categoria verbal em nossa língua. ${ }^{12}$

Castilho faz um rápido apanhado sobre o verbo e suas categorias; passa à exposição do "Estado da Questão do Aspecto", falando da descoberta da noção aspectual num rápido histórico em que, além das referências ao estudo do aspecto por estudiosos de vários países, anota umas poucas referências a autores de Língua Portuguesa que trataram da categoria aspectual. Na apresentação do "Estado da Questão do Aspecto" fala também da contribuição de diferentes escolas linguísticas ao estudo do aspecto e finalmente busca distinguir entre aspecto e modo de ação.

Após ligeira exposição sobre o método de trabalho, passa a falar d' "O aspecto verbal na língua portuguesa", explicitando que seu objetivo foi "estudar o quadro dos aspectos no Português e os recursos de que a língua dispõe para sua expressão".

Castilho expõe um quadro aspectual que procuraremos apresentar o mais resumidamente possível logo adiante, e aponta como meios de expressão do aspecto o semantema do verbo, a flexão temporal, os adjuntos adverbiais, certos tipos oracionais, o complemento do verbo, as perífrases e os sufixos.

Do capítulo II ao capítulo V, Castilho expõe com farta exemplificação como se expressa cada aspecto em particular pelos recursos acima. Termina apresentando uma conclusão em que, além de resumir as contribuições que fez ao estudo do

\footnotetext{
${ }^{12}$ Além do trabalho de Castilho conhecemos apenas o trabalho de Gomes Neto (1977) ao qual nos referimos mais adiante.
} 
aspecto, coloca vários pontos relacionados à categoria que ele julga que merecem ser estudados por outros trabalhos.

Evidentemente não é possível inserir aqui tudo o que diz o trabalho de Castilho, todavia vamos apresentar, de maneira bastante sintética, o conceito de aspecto e o quadro aspectual dados por Castilho, para que deles possa ter ideia quem não tenha acesso ao seu trabalho. Quanto aos meios de expressão do aspecto limitarnos-emos à enumeração feita acima. Entretanto na medida em que colocações de Castilho tiverem relação com nosso trabalho, faremos as referências e citações nos pontos em que se fizerem necessárias.

Castilho conceitua aspecto em três passagens diferentes: à página 14, diz que aspecto "é a categoria que atualiza o processo definindo-lhe a duração" e também que "aspecto é a visão objetiva da relação entre o processo e o estado expressos pelo verbo e a ideia de duração ou desenvolvimento. É pois a representação espacial do processo"; à página 41, Castilho conceitua o aspecto como "a categoria que se reporta aos graus de realização da ação".

Quanto ao quadro aspectual apresentado por Castilho, temos inicialmente a colocação de quatro valores fundamentais a que correspondem os quatro aspectos principais da língua e que Castilho apresenta no seguinte quadro:

\begin{tabular}{c|c}
\hline VALOR & ASPECTO \\
\hline Duração & Imperfectivo \\
\hline Completamento & Perfectivo \\
\hline Repetição & Iterativo \\
\hline Neutralidade & Indeterminado
\end{tabular}

Os quatro aspectos básicos apresentam subdivisões que Castilho esquematiza no seguinte quadro:

\begin{tabular}{l|l}
\hline \multicolumn{1}{c|}{ VALORES } & \multicolumn{1}{c}{ ASPECTOS } \\
\hline 1. Duração & $\begin{array}{l}\text { Imperfectivo } \\
\text { Inceptivo } \\
\text { Cursivo } \\
\text { Terminativo }\end{array}$ \\
\hline 2. Completamento & $\begin{array}{l}\text { Perfectivo } \\
\text { Pontual } \\
\text { Resultativo } \\
\text { Cessativo }\end{array}$ \\
\hline 3. Repetição & $\begin{array}{l}\text { Iterativo } \\
\text { Iterativo imperfectivo } \\
\text { Iterativo perfectivo }\end{array}$ \\
\hline $\begin{array}{l}\text { 4. Negação da duração } \\
\text { e do completamento }\end{array}$ & Indeterminado \\
\hline
\end{tabular}


O aspecto imperfectivo tem três subtipos de acordo com o matiz de duração presente. São os seguintes:

a. aspecto imperfectivo inceptivo que marca a "duração de que se conhecem claramente os primeiros momentos, pressentindo-se o seguimento do processo". Este aspecto apresenta duas subdivisões: o aspecto inceptivo propriamente dito (começo da ação puro e simples) e o aspecto inceptivo incoativo que marca o começo da ação e consequente mudança de estado;

b. aspecto imperfectivo cursivo que marca "a duração de que não se reconhece o princípio nem o fim, apresentando-se o processo em seu pleno desenvolvimento". Este aspecto tem duas variantes: o aspecto cursivo propriamente dito e o aspecto cursivo progressivo que insiste num desenvolvimento gradual do processo;

c. aspecto imperfectivo terminativo que marca "a duração de que se conhece o término".

Para Castilho, "a noção de completamento, peculiar ao aspecto perfectivo, implica na indicação precisa do começo e do fim do processo, polos estes separados por um lapso de tempo extremamente curto e não significativo. As nuanças decorrentes da ação totalmente decursa (portanto o perfectivo, para ele, é o acabado) permitem subdividir o perfectivo em três tipos":

a. o perfectivo pontual que seria o perfectivo por excelência representado graficamente por um ponto;

b. o perfectivo resultativo que indica o resultado consequente ao acabamento da ação;

c. o perfectivo cessativo onde se depreende da ação expressa pelo verbo uma noção de negação que se reporta ao presente.

O aspecto iterativo que surge da noção de ação repetida é considerado como um verdadeiro coletivo de ações que podem ser durativas (o que dá o aspecto iterativo imperfectivo) ou pontuais (o que dá o aspecto iterativo perfectivo). Para Castilho este aspecto é intermediário entre o perfectivo e o imperfectivo. Para ele o hábito surge quando a repetição se faz inconsciente.

$\mathrm{O}$ aspecto indeterminado se caracteriza por não ser nem perfectivo, nem imperfectivo e é avesso não só à expressão de aspecto, mas também à de tempo. 
O próprio Castilho anota à página 49 que as noções de incoação (mudança de estado), de progressão, de resultado e de cessamento não são noções aspectuais, embora sirvam para caracterizar aspectos uma vez que costumam aderir a eles.

Convém ainda destacar que o estudo de Castilho se baseou principalmente em exemplos tirados de escritores brasileiros e portugueses modernos..$^{13}$

$\mathrm{O}$ trabalho de Castilho, bastante rico e profundo, serviu-nos de plataforma primeira para o estudo a que nos propusemos, mas, como se verá, chegamos a resultados bastante diversos tanto no que respeita ao quadro aspectual proposto, quanto no que respeita à interpretação de certos fatos. Além disso, damos um passo adiante ao explicitar e explicar certos mecanismos que Castilho não apontou como também ao colocar e explicar uma série de fatos relativos ao aspecto e aos quais Castilho não se refere.

\subsubsection{0 - OUtROS AUTORES}

Fora os trabalhos aqui já citados cumpre-nos fazer certas anotações sobre outros. Rocha Lima (1973) não fala de aspecto ou de noções aspectuais nem diretamente, nem indiretamente. Cretella Jr. (1953) nega a existência do aspecto nas línguas românicas o que só nos permite utilizá-lo como um trabalho de caráter geral. Gomes Neto (1977) não traz nenhuma contribuição inteiramente nova ao estudo do quadro aspectual do Português e sua expressão, uma vez que seu objetivo era verificar quantas e quais modalidades de aspecto se realizam na literatura de cordel, quantas e quais eram as formas de expressão dessas modalidades e se o aspecto verbal se realiza diferentemente na literatura propriamente dita e na literatura de cordel e, em caso afirmativo, quais as diferenças. Gomes Neto, pela eliminação das noções de incoação, progressão, resultado e cessação (que o próprio Castilho já afirmara não serem aspectuais) e do indeterminado por não ser aspecto (segundo ele) reduz o quadro aspectual apresentado por Castilho ao seguinte: ${ }^{14}$

\begin{tabular}{l|l}
\hline \multicolumn{1}{c|}{ EXPRESSÕES } & \multicolumn{1}{c}{ ASPECTOS } \\
\hline \multirow{2}{*}{ I. Duração } & I. Imperfectivo \\
& I.A. Inceptivo \\
& I.B. Durativo \\
& I.C. Terminativo \\
\hline II. Completamento & II. Perfectivo (Pontual) \\
\hline III. Repetição & III. Iterativo \\
\hline
\end{tabular}

\footnotetext{
${ }^{13}$ Veja-se a este respeito o que diz Castilho (1967, p.48), item 31.

${ }^{14}$ Gomes Neto (1977, p.49).

${ }^{15}$ Corresponde este aspecto ao "Imperfectivo cursivo propriamente dito" de Castilho.
} 
Como resposta à questão motivo de seu trabalho, Gomes Neto anota que não há diferenças significativas entre a literatura propriamente dita e a literatura de cordel no que se refere ao aspecto e sua expressão. Alude a um outro trabalho que aborda especificamente o aspecto: seria o Reflexões sobre o aspecto verbal de Simões Ventura publicado em Coimbra em 1921, mas nem ele nem Castilho encontraram o referido trabalho para ler. Nós também não pudemos consultar este estudo sobre o aspecto. Brandão ${ }^{16}$ apresenta um quadro aspectual e enumera recursos linguísticos de expressão sem especificar o que cada um pode expressar, mas não acrescenta nada de novo ao que já foi dito.

Cremos ter exposto o que de mais pertinente há sobre o aspecto no Português. Os motivos de semelhante exposição são claros: dar uma visão geral do que já se estudou sobre o aspecto em nossa língua e facilitar o entendimento de referências feitas neste trabalho.

\footnotetext{
${ }^{16}$ BRANDÃO, Cláudio. Sintaxe clássica portuguesa. Belo Horizonte: Imprensa da Universidade de Minas Gerais, 1963. Não tivemos acesso a esta obra. Nossa observação é baseada nas informações de Castilho (1967, p.28)
} 


\section{2 - O conceito de aspecto e as noções aspectuais}

\section{1 - O CONCEITO DE ASPECTO}

Pode-se observar com facilidade, pelo exposto sobre o estudo do aspecto no Português e também em numerosos estudos sobre a categoria em outras línguas, que a conceituação de aspecto tem variado muito, sendo, quase sempre, incapaz de abranger todas as noções arroladas como aspectuais e o quadro aspectual daí resultante. Entretanto um exame mais cuidadoso revela alguns pontos mais ou menos comuns entre diferentes conceituações a saber:

1. $\quad$ aspecto seria "a maneira de ser da ação";

2. aspecto é a indicação da duração do processo, de sua estrutura temporal interna; ${ }^{2}$

3. aspecto é a indicação dos graus de desenvolvimento, de realização do processo, o modo de conceber o desenvolvimento do processo $\mathrm{em} \mathrm{si} ;^{3}$

\footnotetext{
${ }^{1}$ CÂMARA JÚNIOR (1974a); CÂMARA JÚNIOR, J. M. Princípios de linguística geral. Rio de Janeiro: Acadêmica, 1974b. 333p.; GARCIA (1976); PONTES, E. Estrutura do verbo no português coloquial. Petrópolis: Vozes, 1972.; QUIRK, R. et al. A grammar of contemporary English. London: Longman Group, 1972. 1.120p.

${ }^{2}$ AZEVEDO FILHO, L. A. de. Para uma gramática estrutural da língua portuguesa. Rio de Janeiro: Gernasa, 1975; CÂMARA JÚNIOR (1974a); CASTILHO (1967); COMRIE, B. Aspect: an introduction to the study of verbal aspect and related problems. London: Cambridge University Press, 1976. 142p.; CRETELLA JUNIOR., J. O aspecto e o tempo no sistema verbal. Jornal de Filologia, São Paulo, v.1, n.2, p.135-141, 1953.; DUBOIS, J. et al. Dicionário de linguística. São Paulo: Cultrix, 1978. 653p.; GARCIA (1976); LUFT, C. P. Moderna gramática brasileira. Porto Alegre: Globo, 1976.; MEILLET, A. Linguistique historique et linguistique genérale. 2. Paris: Librairie Honoré Champion, 1972. v. 2 apud CASTILHO 1967.

${ }^{3}$ BORBA, F. da S. Pequeno vocabulário de linguística moderna. 2. ed. São Paulo: Nacional, 1976. 149p.; CARRETER, F. L. Diccionário de términos filológicos. 3. ed. Madrid: Gredos, 1974. 460 p.; CASTILHO (1967); CRETELLA JÚNIOR (1953); DUBOIS et al. (1978); GUILLAUME, G. Immanence et transcendance dans la categorie du verbe, esquisse d'une théorie psychologique de l'aspect. In: CASSIRER, E. et al. Essais sur le langage. Paris: Éditions de Minuit, 1969. p.207-225.; HOCKETT,
} 
4. aspecto envolve tempo; ${ }^{4}$

5. aspecto é definido como marcador de oposições entre certas noções ou de noções simples: término/não término, início, resultado, etc. ${ }^{5}$

O primeiro destes pontos revela-se pouco útil na definição do aspecto por ser passível de levar a confusões com elementos não aspectuais ligados tanto ao modo verbal e à modalidade (tais como dúvida, necessidade, obrigação, possibilidade, volição, etc.), quanto ao que muitos linguistas chamam de modo de ação ou aktionsart ${ }^{6}$, como dizem os alemães (aqui se incluiriam provavelmente noções como progressão, aparência, conação, diminuição, etc.). O quinto destes pontos comuns às conceituações de aspecto só nos auxilia na medida em que pode nos ajudar a perceber a generalização que envolve as oposições e noções citadas. Já os pontos 2, 3 e 4 nos dão os elementos de partida para uma boa conceituação de aspecto.

Em primeiro lugar é preciso ter em mente que o aspecto é uma categoria verbal ligada ao "TEMPO". Antes de continuarmos, para evitar qualquer dúvida, é preciso esclarecer que neste trabalho utilizaremos o termo tempo em três sentido básicos:

1. Tempo 1: categoria verbal (correspondente às épocas: passado, presente, futuro). Falaremos então em tempo;

2. Tempo 2: flexão temporal. Estaremos nos referindo então aos agrupamentos de flexões da conjugação verbal: presente do indicativo, pretérito imperfeito do indicativo, futuro do presente, futuro do subjuntivo, etc. Falaremos então em tempos flexionais;

3. Tempo 3: a ideia geral e abstrata de tempo sem consideração de sua indicação pelo verbo ou qualquer outro elemento da frase. Falaremos então de TEMPO (com letras maiúsculas).

C. F. A course in modern linguistics. New York: Macmillan, 1964. 621 p.; HOLT, J. Études d'aspect. Acta Jutlandica, Copenhagen, v.15, n.2, p.1-84, 1943.; IMBS, P. L'emploi des temps verbaux en français moderne: essai de grammaire descriptive. Paris: C. Klincksieck, 1960. 272 p.; MEILLET (1958) apud CASTILHO (1967).

${ }^{4}$ ALONSO, C. H. Sobre el tiempo en el verbo español. Revista Española de Linguistica, Madrid, v.3, n.1, p.143-178, jan./jun. 1973.; COMRIE (1976); CURTIUS apud CASTILHO (1967, p.21); DUCROT, O.; TODOROV, T. Dicionário enciclopédico das ciências da linguagem. São Paulo: Perspectiva, 1977. 355p.; GUILLAUME (1969); HOCKETT (1964); IMBS (1960); LUFT (1976).

${ }^{5}$ CÂMARA JÚNIOR (1974a); LUFT (1976).

${ }^{6}$ Vários trabalhos buscam distinguir aspecto e modo de ação. No Português dois trabalhos que se ocupam disso são Castilho (1967) e Gomes Neto (1977). Não vamos aqui tratar de tal distinção, mesmo porque, para um grande número de linguistas, os dois termos são sinônimos, enquanto para outros "aktionsart" seria o aspecto expresso lexicalmente e, para outros ainda, o aspecto seria um tipo de modo de ação, sendo poucos os que consideram os dois como categorias perfeitamente distintas. Preferimos que, uma vez definido aspecto, outras noções sejam eliminadas por não se encaixar na definição dada, uma vez que o aspecto está bem melhor definido como categoria do que o modo de ação. 
Dois exemplos bastam para deixar explícita a distinção entre tempo e tempo flexional que nos parece ser bastante clara:

4. Amanhã irei a Santos tempo futuro tempo flexional: futuro do presente

5. Amanhã vou a Santos. tempo futuro tempo flexional: presente do indicativo

O aspecto é, como dissemos, uma categoria verbal ligada ao "TEMPO", pois antes de mais nada ele indica o espaço temporal ocupado pela situação ${ }^{7}$ em seu desenvolvimento, marcando a sua duração ${ }^{8}$, isto é, o tempo gasto pela situação em sua realização.

Vem daí a confusão que muitas vezes se estabelece entre a categoria de tempo e a de aspecto, independente das duas serem muitas vezes expressas pelo mesmo elemento, o que veremos mais adiante: tanto tempo quanto aspecto são categorias de TEMPO, entretanto as duas não se confundem pois:

- a categoria de tempo situa o momento de ocorrência da situação a que nos referimos em relação ao momento da fala como anterior (passado), simultâneo (presente) ou posterior (futuro) a esse mesmo momento. É uma categoria dêitica, uma vez que indica o momento da situação relativamente à situação de enunciação. Aqui temos uma datação;

- a categoria de aspecto não é uma categoria dêitica, pois se refere à situação em si. Como diz Comrie (1976) o aspecto são as diferentes maneiras de ver a constituição temporal interna da situação, sua duração. Assim para efeito de distinção podemos dizer que o tempo é "um TEMPO externo à situação" e o aspecto é "um TEMPO interno à situação".

O que vimos até agora, todavia, não caracteriza o aspecto de forma completa. $\mathrm{O}$ aspecto também indica algo sobre o grau de desenvolvimento, de realização da situação como anotaram vários autores (cf. nota 18). Muitos deles falam em término (acabado)/ não término (não acabado) e em noções como início, meio e fim. Todas essas colocações, entretanto, nunca trazem em seu bojo uma conceituação capaz de abranger todas as noções diferentes da duração e arroladas como aspectuais.

\footnotetext{
${ }^{7} \mathrm{O}$ termo situação será usado neste trabalho como um termo geral para processos, estados, fenômenos, eventos, fatos, etc. Alguns tipos particulares de situações serão definidos mais adiante.

${ }^{8}$ A maioria dos autores fala em duração da situação mas Alonso (1973) fala em tempo interno, Guillaume (1969) fala em "tempo implicado"e Comrie (1976) fala em "estrutura temporal interna".
} 
Confrontando todas as conceituações de aspecto, listando as noções aspectuais arroladas, naturalmente com expurgo daquelas que não se encaixam nas conceituações e podiam ser consideradas ligadas a outras categorias ou como simples noções semânticas não afetas a qualquer categoria, e aplicando o resultado a inúmeros exemplos; pudemos notar que as noções enumeradas como aspectuais, normalmente indicavam fases da situação. ${ }^{9}$ Entretanto nem todas podiam ser ordenadas num mesmo conjunto de fases, ou seja, acabado/não acabado, por exemplo, não se encaixava na sequência de fases: início, meio e fim. Uma análise um pouco mais atenta mostrou que as fases da situação podiam ser tomadas de diferentes pontos de vista e, daí, termos de organizar diferentes subconjuntos de fases de acordo com o ponto de vista considerado. Nosso estudo revelou haver três pontos de vista diferentes, que são:

a. o do desenvolvimento da situação, o que nos dá três fases: início, meio e fim;

b. o do completamento da situação, o que nos dá duas fases: a da situação incompleta e da situação completa;

c. o da realização da situação ${ }^{10}$, o que nos dá três fases: a da situação por começar, a da situação começada ou não acabada e a da situação acabada. ${ }^{11}$

Na verdade, as fases que chamamos "do desenvolvimento da situação" (início, meio e fim) podem ser consideradas como subdivisões da "fase de realização" que chamamos de "fase da situação começada ou não acabada".

As fases também colocam o aspecto como uma categoria de TEMPO, pois nada mais são do que "pontos" no segmento de TEMPO envolvido na ocorrência da situação.

Nesta altura cremos poder reunir tudo o que foi dito para definir aspecto num conceito mais sintético:

Aspecto é uma categoria verbal de TEMPO, não dêitica, através da qual se marca a duração da situação e/ou suas fases, sendo que estas podem ser consideradas sob diferentes pontos de vista, a saber: o do desenvolvimento, o do completamento e o da realização da situação.

\footnotetext{
${ }^{9}$ Guillaume também diz que aspecto é a fase de desenvolvimento do processo. Veja Guillaume (1969) e Castilho (1967, p.34).

${ }^{10}$ Deve ficar claro que estamos utilizando os termos desenvolvimento e realização da situação com significados específicos e distintos para identificar dois pontos de vista diferentes.

${ }^{11}$ Muitos autores consideram a oposição acabado/não acabado como idêntica à oposição completo/não completo, dando os termos como sinônimos. Para nós, esta equiparação causou problemas no estudo do aspecto, pois, na verdade, não são a mesma coisa como propomos mais adiante.
} 
Alguns autores ${ }^{12}$ dizem que o aspecto é a representação ou atualização espacial do processo, isto porque, como dissemos, ele localiza a situação dentro do espaço temporal de sua ocorrência.

A quase totalidade dos estudiosos concordam em afirmar que o aspecto é uma noção mais objetiva e concreta que o tempo, pois se refere à situação em si. Entretanto a apresentação de uma situação dentro de uma ou de outra noção aspectual não é necessariamente objetiva, pois depende de como o falante pretende referir-se à duração e/ou às fases da situação ou mesmo não referir-se a elas e não de como a situação é na realidade, embora isto possa influenciar. Além disso a mesma situação pode ser vista de diferentes maneiras não só de uma língua para outra, mas também dentro da mesma língua. Assim quando se diz, por exemplo:

6. Antônio falou ontem na Universidade. Enquanto falava muitos alunos fizeram perguntas.

A mesma situação (falar) é apresentada primeiro como completa (falou) e depois como incompleta (falava).

Ao enunciarmos uma frase, inúmeros elementos influem sobre qual noção aspectual caracteriza a situação apresentada e, no momento oportuno, iremos especificando-os, antes, porém, importa estabelecer com mais clareza as noções aspectuais que a definição do aspecto apenas deixou entrever.

\section{2 - NoçÕES ASPECTUAIS}

\subsection{1 - PRELIMINARES}

O elenco de noções aspectuais, que vamos apresentar nesta seção, foi estabelecido levando-se em conta dados da Língua Portuguesa.

Inicialmente é preciso deixar claro que inúmeras noções presentes nos verbos, tanto no Português quanto em outras línguas, e que são apresentadas como aspectuais, nada têm a ver com aspecto, pois nada dizem da duração da situação ou de suas fases. Estão neste caso "aspectos" como intensivo, potencial, conativo, comitativo, inferencial ou putativo, negativo, diminutivo, reflexivo, pejorativo, obrigatório, desiderativo, benefactivo, aparencial, reservativo, todos relacionados por Luis Cifuentes Garcia. ${ }^{13}$ Borba (1976, p.7-9) cita vários destes “aspectos” e mais ainda outros que em realidade não o

\footnotetext{
${ }^{12}$ Cf., por exemplo, Borba (1976, p.7) e Castilho (1967, p.14).

${ }^{13}$ GARCIA, L. C. Acerca del Aspecto. Boletin de Filologia, Chile, t. 8, p.57-63, 1954 apud CASTILHO (1967, p.42).
} 
são tais como o causativo, o deteriorativo, o distribuitivo, o necessitativo e o reservativo. No item 1.3.7 explicitamos várias noções não aspectuais que Garcia (1976) arrola como tal. Castilho $\left(1967\right.$, p.41, 43) ainda cita vários aspectos colocados por Louis Roussel ${ }^{14}$ tais como: de velocidade, de plenitude, de fraqueza, inversivo, aditivo, de predileção, de interesse pessoal, etc. apontando que nada têm a ver com aspecto.

Para evitar que noções semânticas não aspectuais, presentes no verbo, sejam arroladas entre as noções verdadeiramente aspectuais, é suficiente verificar se a noção semântica em questão é uma noção temporal não dêitica que indica a duração da situação ou uma de suas fases, pois, caso contrário, não será uma noção aspectual.

Duas noções temporais que às vezes são apontadas como aspectuais, mas que na verdade são noções de tempo, são a iminência de ação e o passado recente que as frases abaixo exemplificam:

7. a - José acabou de sair. Se você chegasse um pouco antes teria falado com ele (passado recente).

b - O chefe de estação deu o sinal. O trem vai partir (iminência de ação).

c - Sua encomenda está para chegar (iminência de "ação").

Como veremos adiante, às vezes temos juntas, em uma perífrase ou num tempo flexional ou em outro recurso de expressão do aspecto, uma noção de aspecto e uma de tempo, mas é preciso saber separar as duas.

Feitas essas observações iniciais, passemos às noções que caracterizam aspectos.

\subsection{2 - NOÇÕES ASPECTUAIS}

Ao considerar o TEMPO envolvido na ocorrência de uma situação é preciso lembrar que toda situação tem princípio, meio e fim; um antes de seu princípio em que ela é não começada ou por começar e um depois de seu fim em que ela é acabada. Isto pode ser representado graficamente e de modo geral pela figura 1 .

FIGURA 1

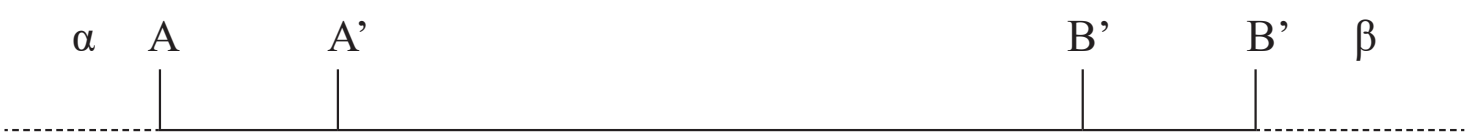

Na FIG. 1, $\alpha$ é o TEMPO em que a situação ainda é não começada e $\beta$ o tempo em que ela é acabada; A é o ponto de início da situação, B o ponto de tér-

$\overline{{ }^{14} \text { ROUSSEL, L. L'aspect en grec attique. Paris: PUF, } 1958 .}$ 
mino e o segmento AB é a duração da situação, seu TEMPO de desenvolvimento; AA' são os primeiros momentos do desenvolvimento da situação e B'B os últimos momentos de seu desenvolvimento. A extensão dos segmentos em termos absolutos no mundo real é algo que não importa, pois tudo vai depender de como o falante concebe a situação e de como deseja apresentá-la.

\subsubsection{1 - DuRAção E PONTUALIDADE}

Duração é a primeira noção semântica aspectual. Em oposição à duração temos a não duração ou pontualidade que é o caso da situação cujo início e término ocorrem no mesmo instante ou separados por um lapso de TEMPO curto, de tal forma que a situação é concebida como pontual. ${ }^{15}$

A duração pode ser referida de diferentes maneiras:

a. Como limitada: quando se indica seu início (exemplos 8 a, b) ou seu fim (exemplos 9 a, b) ou o valor da duração (exemplo 10), ou quando, mesmo sem nenhuma limitação explícita, a situação é sentida como tendo uma duração finita (exemplos. 11 a-c). Portanto os limites A e B da Figura 1 são conhecidos ou sugeridos.

8. a - Ele estava nadando desde as 6 horas da manhã.

b - Sílvia limpava a casa desde cedo e ainda não acabara, quando voltamos.

9. a - João ficará estudando até amanhã.

b - Papai estaria trabalhando até as 20 horas.

10. Antônio ouviu música o dia todo.

11. a - José lia um romance, quando sua irmã chegou.

b - Estamos fazendo um bolo para mamãe.

c - Minha cabeça tem doído muito.

b. Como ilimitada: os limites A e B na figura 1 não são conhecidos nem sugeridos. Aparece normalmente em frases indicativas de situações, "eternas" ou sentidas como tal numa dada época. É o caso, por exemplo, de frases que expressam princípios científicos ou verdades "eternas" (tais como provérbios e máximas). Muitos autores dizem que essas frases normalmente são atemporais, isto é, não atualizam a categoria de tempo, porque normalmente indicam coisas válidas para todo o tempo, todavia temos a duração sentida

\footnotetext{
${ }^{15}$ Alguém pode argumentar que a situação pontual não existe, pois qualquer situação tem uma duração por menor que seja. Realmente isso é verdade, mas o que importa não é a medida do tempo em termos absolutos, e sim, como já dissemos, o sentimento linguístico do falante que concebe a situação como pontual.
} 
como ilimitada no presente (que é o mais comum e onde a ideia de tempo parece se enfraquecer mais), no passado e no futuro. Exemplos.:

12. A Terra gira em torno do Sol.

13. A mocidade busca a mocidade. (C. dos Anjos $)^{16}$

14. Este cachorro morde.

15. A verdade não envergonha.

16. As almas condenadas vaguearão para sempre.

17. Os bons serão felizes na vida eterna.

18. Meu avô era pessoa de boa índole.

19. O clube ficava no topo da colina.

Pode-se observar que, embora tenhamos nos exemplos acima o presente do indicativo, o pretérito imperfeito do indicativo e o futuro do presente como tempos flexionais, não podemos garantir sem dúvida que aí tenhamos a categoria de tempo atualizada em passado, presente e futuro.

É bom lembrar ainda que, como uma duração ilimitada normalmente não apresenta muita significação para o espírito humano, há nestes casos uma tendência para reduzir ou anular a indicação da duração, e o verbo passa a ser sentido como referindo-se mais ou só à situação.

c. Como contínua: quando a situação é apresentada sem nenhuma interrupção no seu tempo de existência, de desenvolvimento. São exemplos deste tipo de duração os exemplos de números 8 a 19, exceto 11-c. Pelos exemplos fica claro que a duração contínua pode ser limitada ou ilimitada;

d. Como descontínua: quando a situação é apresentada como sofrendo interrupções na sua duração, o que cria a ideia de repetição (iteração). ${ }^{17}$ Da ideia de repetição vem a caracterização que se dá desse fato, como representando uma coleção de situações. ${ }^{18}$ A repetição existe, então, porque existem interrupções no TEMPO de ocorrência de uma situação.

Podemos ter repetição tanto de situações durativas (exemplos 11-c, 20 a 22) quanto de situações pontuais (exemplos 23 a 25).

\footnotetext{
${ }^{16}$ Exemplo apud Castilho (1967, p.104).

${ }^{17}$ Guillaume (1969, p.218-9) anota que a ruptura da continuidade do tempo imanente e do tempo transcendente é um acidente que tem consequências extremamente variadas, uma das quais é o surgimento de formações mais ou menos iterativas. Cf., na nota 35, o que diz IMBS (1960).

${ }^{18}$ É o que faz Castilho (1967) sem explicar de onde vem a ideia de repetição.
} 
20. D. Maria passeia todos os dias na praia.

21. Você precisaria ouvir o que tenho ouvido.

22. Andamos assistindo muito à televisão (presente do indicativo).

23. De tempos em tempos explodia uma bomba.

24. Tenho pulado corda para emagrecer.

25. Sempre acordo às 6 horas.

A iteração tanto da situação pontual quanto da durativa cria uma série que pode ser representada como uma situação única. ${ }^{19}$ Isto pode ser observado nos exemplos (11-c) e (20) a (25) e também nos exemplos (26) e (27).

26. Salto do trampolim há anos.

27. Compro dele faz muito tempo.

Em todos os exemplos temos situações que se repetem, mas que são apresentadas como uma situação durativa única. Quando percebemos a situação iterativa desta forma, é porque deixamos de considerar cada realização da situação para pensar, no dizer de IMBS (1960, p.24), "na disposição ou aptidão contínua" que as condiciona. ${ }^{20} \mathrm{~A}$ série durativa única criada pela repetição tem uma duração descontínua como se pode ver facilmente.

Se observarmos as frases (20), (25), (26) e (27) veremos que aí, além da iteração, há uma ideia de hábito. Não é muito fácil explicar como uma iteração se torna habitual, mas algo pode ser dito: a) a repetição (iteração) que se torna inconsciente e automática torna-se hábito; b) no hábito a repetição parece ser mais regular, constante, não havendo falhas nas repetições da situação, daí o adjunto adverbial ter normalmente sentido totalizador em frases de repetição habitual: "todos os dias" (exemplo 20) e "todas as noites" (exemplo 29); ${ }^{21}$ c) na iteração simples a duração descontínua é limitada, enquanto que na iteração habitual a duração é ilimitada. Esta diferença entre a iteração simples e a habitual pode ser percebida claramente confrontando as frases (11-c), (21), (22),

\footnotetext{
${ }^{19}$ Esse fato é observado por Lyons (1977, p.716) aproximadamente com estas palavras. (LYONS, J. Semantics. Cambridge: Cambridge University Press, 1977. v.2.).

20 "La répétition et l' habitude, tout en les montrant engagés dans un rythme, présentent les processus verbaux comme discontinus. Mais si, au lieu de considérer les actes on pense à la disposition ou à l' aptitude continue qui les conditionne, le verbe n'est plus engagé dans um rythme, et il est de ce fait privé de toute détermination quantitative". Tradução: "A repetição e o hábito apresentam os processos verbais como descontínuos ao mesmo tempo que os mostram engajados num ritmo. Porém, se ao invés de considerar os atos, se pensa na disposição ou na aptidão contínua que os condiciona, o verbo não é mais engajado num ritmo e está, por este fato, privado de toda determinação quantitativa.

${ }^{21}$ Mais adiante veremos que o adjunto adverbial tem muito a ver com o aspecto.
} 
(23) e (24), em que a iteração é simples, com as frases (20) e (25) a (29), em que a iteração é habitual.

28. Nunca leio artigos políticos.

29. Todas as noites escovava os dentes com cuidado.

Compare-se (30-a) que é habitual com (30-b) que é uma iteração simples:

30. a - Antônio vai à missa aos domingos.

b - Antônio tem ido à missa aos domingos.

Em (30-b) percebe-se um limite às repetições, o que não ocorre em (30-a). Como se pode ver, também a duração descontínua pode ser limitada ou ilimitada.

Tudo isso pode levar a pensar que, para uma iteração tornar-se habitual, é preciso que o número mínimo de repetições seja bastante alto. Esse número seria impossível de determinar, pois a apresentação de uma situação como habitual depende apenas da vontade do falante de fazê-lo e não do número de repetições que ocorrem na realidade.

Como veremos mais adiante, a habitualidade não é uma noção aspectual, mas sim a iteração de que a habitualidade nasce, pois é a iteração que surge da duração descontínua.

Para Comrie (1976, p.26-27), nem todo habitual é iterativo; contudo, pelo que pudemos averiguar para o Português, todo habitual é iterativo, ${ }^{22}$ pois não encontramos um só exemplo em que isto não se desse. Encontramos apenas casos em que a iteração parece atenuada, menos explícita, como no exemplo (27), porque aí ocorre o que IMBS (1960, p.24) disse e a que já aludimos acima após esse exemplo. Alguém poderia argumentar que as frases habituais negativas, como o exemplo (28), podem ser apontadas como casos em que temos o habitual não iterativo. Semelhante proposição não teria validade porque o que ocorre nestes casos é a negação da iteração habitual, mas não a sua ausência. Resta anotar que, embora todo habitual seja iterativo, não vale a recíproca, pois abundam as frases de sentido iterativo que não são habituais.

\footnotetext{
${ }^{22}$ O exemplo que Comrie (1976, p.27) apresenta de habitual não iterativo para o inglês, após dizer que "uma situação pode ser referida por uma forma habitual sem haver qualquer iteratividade” é: (grifo nosso).

a) The Temple of Diana used to stand at Ephesus.

Este exemplo realmente apresenta uma forma de habitualidade do inglês (used to) e expressa algo que não pode ter uma duração descontínua e portanto não pode ser iterativo.

O exemplo de Comrie, se passado para o Português com uma forma habitual correspondente, resultará numa frase inaceitável, por ser semanticamente anômala:

b) *O templo de Diana costumava (ou usava) ficar em Éfeso.

O exemplo de Comrie com exatamente o mesmo significado teria que ser traduzido para o Português, utilizando-se uma frase como c, de aspecto indeterminado (cf. item 4.2.5), semelhante ao exemplo (19):

c) O templo de Diana ficava em Éfeso
} 
Tendo em vista que as frases de sentido iterativo habitual apresentam situações de duração descontínua ilimitada, elas também expressam as chamadas verdades eternas em frases como as registradas com os números (31) a (33), exatamente como ocorre com as frases em que a duração é contínua e ilimitada (cf. exemplos 12 a 19). ${ }^{23}$

31. Aves se alimentam de vegetais.

32. As azaleias florescem em maio.

33. Os ratos roem papel.

Em consequência desse papel do habitual há, muitas vezes, como veremos adiante, um problema de análise que consiste na dificuldade de distinguir se temos, numa dada frase, o aspecto caracterizado pela duração contínua ilimitada ou o aspecto caracterizado pela duração descontínua ilimitada, já que os dois aparecem em frases que expressam verdades "eternas" atemporais.

\subsubsection{2 - FASES}

Vimos as noções aspectuais ligadas à duração da situação. Passemos agora às noções ligadas às suas fases.

Inicialmente temos as fases da situação do ponto de vista da sua realização, que são três, a saber:

a. A fase em que a situação ainda não começou. Na FIG. 1 corresponde ao trecho - do espaço de TEMPO. A situação é apresentada como algo ainda por fazer, por ocorrer, por começar, embora haja ou tenha havido "intenção" ou "certeza", de ela se realizar. Exemplos:

34. Esta gaveta está por arrumar, mas só farei isto quando tiver tempo.

35. Pedro está para emoldurar o quadro.

36. Seu irmão está para chegar.

37. Este livro ficou por ler, pois não tive tempo. ${ }^{24}$

\footnotetext{
${ }^{23}$ Lyons (1977, p.716) observa que, uma vez que "algumas vezes" passa a "muitas vezes" e este pode aproximar-se assintoticamente de "sempre", o habitual é apropriadamente usado na expressão das chamadas verdades atemporais como "Vacas comem capim".

${ }^{24}$ Quando a noção aspectual é expressa por perífrase há uma série de particularidades que serão expostas nos momentos adequados. Apenas a título de esclarecimento observe-se, por exemplo, que, comparando o exemplo (34) com o exemplo (37), notamos que no segundo há uma permansividade do não começado introduzida pelo auxiliar ficar que traz a implicação de que, embora tenha havido, não há mais a intenção de realizar a situação o que não ocorre no primeiro, onde o auxiliar é estar.
} 
Observe-se que nos exemplos (35) e (36) a noção é de "prestes a começar", porque junto à noção aspectual há a expressão da noção temporal de iminência de ação.

b. A fase em que a situação já é começada. Na FIG. 1 corresponde ao segmento AB do espaço de TEMPO. A situação é apresentada como em realização. Embora a fase seja apenas uma e a noção aspectual por ela representada seja única, esta fase pode ser tomada de dois ângulos diferentes conforme se tenha em mente opô-la à fase em que a situação é não começada ou à fase em que a situação é acabada. Se temos em mente opôr a fase da situação em realização à fase em que ela é não começada, dizemos que a situação é começada, se temos em mente opô-la à fase em que a situação é acabada, dizemos que a situação é não acabada. Exemplos:

Veja exemplos: (8a, b), (11a, b)

38. Os rapazes continuam jogando apesar da chuva.

39. Mesmo percebendo notas de desagrado, o conferencista prosseguia expondo seu ponto de vista.

c. A fase em que a situação já terminou. Na FIG. 1 corresponde ao trecho â do espaço de TEMPO. A situação é apresentada como terminada, concluída, acabada. Exemplos:

40. Maria leu o livro.

41. Pedro pulara o muro com facilidade.

42. O treinador do time esteve doente.

43. Mamãe acaba de fazer um bolo.

$\mathrm{Na}$ frase (43) a noção é de "acabado há pouco", porque junto à noção aspectual há a expressão da noção temporal de passado recente.

A partir do momento em que a situação entra em realização, dizemos que ela está em desenvolvimento e aí temos suas fases do ponto de vista do desenvolvimento, a saber: início, meio e fim. Vejamos cada uma em particular:

a. Início: À noção aspectual caracterizada pela fase de início da situação chamaremos de incepção ou inceptividade. Temos incepção quando a situação é apresentada como estando em seu ponto de início (o ponto A da FIG. 1), ou em seus primeiros momentos (na FIG. 1 corresponde ao segmento AA' do espaço de tempo). Exemplos: 
44. Os marceneiros estão começando a armar o telhado.

45. Neste instante os balões começam a subir.

46. Num dado momento o povo rompeu a vaiar, deixando todos perplexos.

47. Daniel principiava a arrumar a mala, quando cheguei em sua casa hoje de manhã.

48. Jorge começará a soltar os fogos de artifício às 20 horas.

Nos exemplos (46) e (48) a situação é apresentada em seu ponto de início, nos exemplos (44) e (47) a situação é apresentada em seus primeiros momentos, o exemplo (45) parece poder ser interpretado das duas maneiras, embora haja tendência para ver a situação como em seus primeiros momentos.

b. Meio: À noção aspectual caraterizada pela fase de meio da situação chamaremos de cursividade. Temos cursividade, quando a situação é apresentada em pleno desenvolvimento, isto é, concebida como já tendo passado seus primeiros momentos e ainda não tendo atingido seus últimos momentos. Isto quer dizer que a situação é apresentada como estando em qualquer ponto do segmento A'B' do espaço de TEMPO representado na FIG. 1. Exemplos:

Veja exemplos (8a, b), (11a, b), (38), (39).

49. Jorge continua falando apesar do avançado da hora.

50. Estou lendo um livro muito interessante.

c. Fim: À noção aspectual caracterizada pela fase de término da situação chamaremos de terminatividade. Esta noção aspectual aparece quando a situação é apresentada como estando em seu ponto de término (o ponto B da FIG. 1), ou em seus últimos momentos (na FIG. 1 corresponde ao segmento B'B do espaço de TEMPO). Exemplos:

51. Espere um momento que estou acabando de arrematar seu vestido.

52. Mamãe terminou de bordar minha blusa hoje ao meio dia.

53. Raquel terminava de escrever a carta quando o telefone tocou.

54. Neste instante Simone termina de cantar a última música do show.

Nos exemplos (51) e (53) a situação é apresentada em seus últimos momentos, no exemplo (52) a situação é apresentada em seu ponto de término. No exem- 
plo (54) parece que podemos ter duas interpretações: a situação em seus últimos momentos (= está terminando de cantar) ou a situação em seu ponto de término (= acaba de cantar neste exato momento).

O Português apresenta a situação mais em seus primeiros ou últimos momentos do que em seu ponto de início ou de término.

É preciso deixar claro desde já que a simples referência ao momento de início da situação, como nos exemplos (8a, b) e (55), ou ao momento de seu término, como nos exemplos $(9 a, b)$ e (56a, b), não caracteriza a presença das noções de incepção e terminatividade, pois, para que elas existam, é preciso que a situação seja apresentada respectivamente em seu momento de início ou em seus primeiros momentos e em seu momento de término ou em seus últimos momentos. Dessa forma nos exemplos referidos neste parágrafo não há incepção ou terminatividade, mas apenas o estabelecimento de um dos limites da duração limitada.

55. O presidente estava falando desde as cinco horas.

56. a - Esperei você até às dez horas.

b - As bolhas de ar ficam pairando no ar até estourarem.

O terceiro grupo de noções aspectuais ligadas às fases da situação é o de noções caracterizadas pelas fases sob o ponto de vista do completamento. Como já vimos, temos aqui duas fases: a da situação completa e a da situação incompleta, e portanto duas noções aspectuais. É bom que fique claro que a noção é de situação que se apresenta como completa e não como completada (ou seja, como acabada, cumprida, concluída, totalmente decursa). A situação é apresentada como completa, isto é, em sua totalidade, como um todo indivisível, com seu começo, meio e fim englobados num todo. Como veremos ao falar dos aspectos, embora seja comum que a situação que é apresentada como completa o seja também como acabada, nem sempre isso ocorre, pois temos situações apresentadas como completas e não acabadas. Temos também situações apresentadas como incompletas e acabadas. É comum termos situações apresentadas como completas, mas sem qualquer indicação sobre se são ou não acabadas. Embora isto possa parecer incoerente ou estranho, mostraremos no momento oportuno que isso é real dentro do sistema linguístico. $\mathrm{O}$ que deve ficar claro agora é que situação completa e incompleta não são sinônimos de situação acabada e não acabada.

São exemplos de situação apresentada como incompleta as situações das frases de números (8a, b), (9b), (11a-c), (20 a 25), (30b), (38), (39), (44), (47), (49 a 51) e (53) entre outras. Exemplos de situação apresentada como completa podem 
ser encontrados nas frases de números (10), (40) a (42), (46), (52) e abaixo nos exemplos (57) a (60).

57. Célia andou indo ao cinema com Élio.

58. A menina esteve balançando lá fora por muito tempo.

59. Quando eles voltarem, já terei preparado o lanche.

60. Maria ficou olhando as fotos durante várias horas.

Pode acontecer que nenhuma dessas noções aspectuais seja atualizada pelo verbo. Neste caso o falante refere-se à situação em si, sem atualizar a categoria de aspecto, como ocorre, em (61) a (63).

61. Seu tio almoçará amanhã conosco.

62. Talvez José compre o carro de você.

63. Varra essa cozinha, menina!

Mais adiante veremos alguns casos em que, normalmente, a categoria de aspecto ou algum aspecto em particular não se atualiza.

As noções aspectuais que vimos nesta seção podem ser resumidas no QUADRO I, da página seguinte.

\section{3 - NoçÕes NÃO ASPECTUAIS, MAS GERALMENTE LIGADAS AO ASPECTO}

\subsection{1 - PRELIMINARES}

Em 2.2.1 falamos de muitas noções não aspectuais arroladas por diferentes autores como aspectuais. Nesta seção, vamos falar mais particularmente de várias noções semânticas que aparecem com frequência na literatura sobre aspecto, normalmente para caracterizar subtipos desta categoria que, entretanto, não são noções aspectuais. Seu constante aparecimento nos estudos aspectuais se explica pelo fato de que elas estão ligadas a algum tipo de aspecto e, muitas vezes, só podem ocorrer na frase em que ele aparece, podendo ser ou não consequência do mesmo. Em outras palavras, o aparecimento destas noções na frase depende na maioria das vezes do aspecto e muitos as têm confundido com aspectos ou seus subtipos.

Estão neste caso as seguintes noções: 


\subsection{2 - HabituALIDADE}

Como vimos em 2.2.2.1, a habitualidade existe quando temos a iteração, que surge da duração descontínua ilimitada. A noção aspectual é essa duração. A habitualidade se liga a esta noção aspectual, porque é dela que surge a repetição sem a qual o hábito não existe, mas não se deve pensar daí que o hábito seja aspecto, mesmo que terminologicamente usemos o termo habitual para distinguir o aspecto caracterizado pela duração descontínua ilimitada, do aspecto caracterizado pela duração descontínua limitada. ${ }^{25}$

QUADRO I

\begin{tabular}{|c|c|c|c|}
\hline \multirow{5}{*}{ 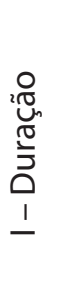 } & \multirow[t]{4}{*}{ 1. Duração } & \multirow[t]{2}{*}{ A. Contínua } & a. Limitada \\
\hline & & & b. Ilimitada \\
\hline & & \multirow[t]{2}{*}{ B. Descontínua } & a. Limitada \\
\hline & & & b. Ilimitada \\
\hline & \multicolumn{3}{|c|}{ 2. Não duração ou Pontualidade } \\
\hline \multirow{11}{*}{ 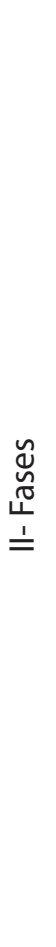 } & \multirow{6}{*}{ 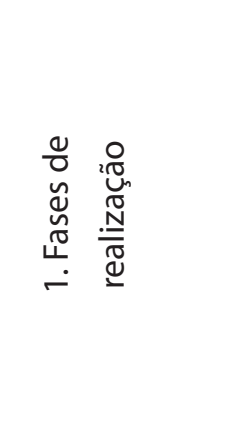 } & \multicolumn{2}{|l|}{ A. Por começar } \\
\hline & & \multirow{2}{*}{\multicolumn{2}{|c|}{$\begin{array}{l}\text { A'. Prestes a começar (ao lado do aspecto } \\
\text { há uma noção temporal) }\end{array}$}} \\
\hline & & & \\
\hline & & \multicolumn{2}{|c|}{ B. Não acabado ou Começado } \\
\hline & & \multicolumn{2}{|c|}{$\begin{array}{l}\text { C'. Acabado há pouco (ao lado do aspecto há uma } \\
\text { noção temporal) }\end{array}$} \\
\hline & & \multicolumn{2}{|l|}{ C. Acabado } \\
\hline & \multirow{3}{*}{ 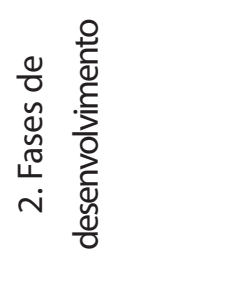 } & \multicolumn{2}{|c|}{$\begin{array}{l}\text { A. Início (no ponto de início ou nos } \\
\text { primeiros momentos) }\end{array}$} \\
\hline & & \multicolumn{2}{|l|}{ B. Meio } \\
\hline & & \multicolumn{2}{|c|}{$\begin{array}{l}\text { C. Fim (no ponto de término ou nos } \\
\text { últimos momentos) }\end{array}$} \\
\hline & \multirow{2}{*}{ 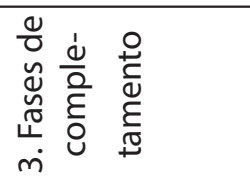 } & \multicolumn{2}{|l|}{ A. Completo } \\
\hline & & \multicolumn{2}{|l|}{ B. Incompleto } \\
\hline
\end{tabular}

\subsection{3 - INCOAÇÃO}

É a indicação de mudança de estado. Como indica o começo de um novo estado é, por muitos, ligada à inceptividade e daí se dizer, às vezes, aspecto incoativo ou

\footnotetext{
${ }^{25} \mathrm{Cf}$. o quadro aspectual no item 4.2 .
} 
inceptivo, como faz Câmara Júnior: ${ }^{26}$ ou de em outras vezes se dividir a inceptividade em inceptivo propriamente dito e inceptivo incoativo como faz Castilho. ${ }^{27}$ Das noções que estamos vendo é, talvez, a menos dependente de aspecto. Exemplos:

64. José adoeceu.

65. A valente tropa fraquejava.

66. As folhas amarelam com o frio.

67. Rogério está engordando muito.

\subsection{4 - Progressividade}

É a indicação de que a situação tem um desenvolvimento gradual. Está ligada ao aspecto que chamaremos de durativo, pois não referimos a desenvolvimento gradual em uma situação pontual, porque, quando isto acontece, a situação pontual é apresentada como durativa. Exemplos:

68. Nossa amizade estreitava-se.

69. O amor dos tios foi transformando aquela criança.

70. Chega o inverno, aos poucos as árvores ficam esqueléticas.

71. O pobre animal morreu pouco a pouco.

Observe-se que em (71) a situação pontual2 "morrer" é vista como durativa por causa da progressividade introduzida pelo adjunto adverbial "pouco a pouco", mesmo estando no pretérito perfeito do indicativo que normalmente faz abstração da duração ou pontualidade (cf. o item 7.3).

Como já vimos, alguns autores propõem um aspecto progressivo, o que não é correto.

\subsection{5 - ResULTATIVIDADE - 1 OU PERMANSIVIDADE}

É a indicação de um estado resultante de uma situação dinâmica (Cf. capítulo 3) que se concluiu. O nome permansividade é uma alusão ao fato de permanecer um estado em consequência do término de uma ação; como diz Câmara Jr. "à maneira de uma coisa adquirida" (Cf. item 1.3.8). Exemplos:

72. Tenho a lição estudada (Isto é, estudei a lição no passado e agora ela está estudada).

\footnotetext{
${ }^{26} \mathrm{Cf}$. o que registramos no item 1.3.8.

${ }^{27} \mathrm{Cf}$. o que registramos no item 1.3.9.

${ }^{28} \mathrm{Cf}$. tipos de situações no capítulo 3 .
} 
73. Bernarda (que vestiu um casaco e tem posta uma mantilha preta. A observar Amália com desconfiança). "Estás hoje muito janeleira, Amália!’ B. Santareno. ${ }^{29}$ (Isto é, pôs a mantilha e agora ela está posta).

74. O jantar está preparado. Quando posso servi-lo? (Isto é, preparei o jantar e agora ele está preparado).

75. Quando chegamos à fazenda o cafezal estava destruído (Isto é, o cafezal tinha sido destruído e no momento da nossa chegada ele já estava destruído).

\subsection{6 - ResultatividADE - $2^{30}$}

É a indicação de que a situação se concluiu com o atingimento de um ponto terminal. Exemplos:

76. Os funcionários varreram o salão.

77. Teresa apagou a luz.

78. Valdir já tinha emoldurado o quadro, quando the telefonei.

79. João matou o cachorrinho com o coração apertado, mas era preciso, porque estava louco.

Esse tipo de resultatividade ocorre com os verbos télicos (Cf. capítulo 3), quando usados com formas que marcam o aspecto que chamaremos de perfectivo (Cf. nota 40). A resultatividade -2 depende deste aspecto e surge sempre ligada ao aspecto acabado.

\subsection{7 - CESSAMENTO}

Aparece quando se depreende da situação expressa pelo verbo uma noção de negação que se reporta ao presente. O cessamento é uma mistura de tempo e aspecto: na medida em que estabelece um contraste entre ontem (ou antes) e agora (momento da enunciação) é temporal; na medida em que indica que a situação é acabada é aspectual. $\mathrm{O}$ cessamento é, pois, uma combinação do aspecto que chamaremos de acabado (cf. nota 40) e de uma noção temporal. Exemplos:

80. Já tive muitos amores, mas agora...

81. Eu, um dia, fui o maior malabarista do mundo.

82. Eu estive doente, por isso faltei a duas aulas.

83. O mecânico esteve aqui para ver o carro.

\footnotetext{
${ }^{29}$ Exemplos (72) e (73) apud Castilho (1967, p.86, 88).
} 


\subsection{8 - EXPERIENCIAMENTO}

Indica que alguém já viveu ou passou por uma determinada situação, pelo menos uma vez. Liga-se ao aspecto que chamaremos de perfectivo, pois só aparece quando este aspecto está presente..$^{30}$ Exemplos:

84. José já esteve no sul do país, eu não.

85. Você alguma vez participou de um concurso de beleza?

86. Uma vez eu falei com o papa.

Como se pode observar nos exemplos acima, o experienciamento no Português é normalmente assinalado pelo verbo no pretérito perfeito do indicativo com o auxílio do advérbio "já" ou de locuções adverbiais do tipo "alguma vez", "uma vez", "certa vez", embora nem sempre o experienciamento seja marcado assim (cf. exemplo 87) e nem sempre a presença destes elementos implique em experienciamento (cf. exemplo 88).

87. Alguma vez você estava assistindo televisão quando o tubo explodiu? (Aqui o experienciamento está em toda a frase e não em uma ou outra forma verbal).

88. Você já estudou para o concurso? (Aqui não há experienciamento. Se tirarmos o artigo definido o de antes de "concurso" passa a haver experienciamento).

\footnotetext{
${ }^{30}$ Comrie (1976, p.58) fala em "experiencial perfect". "Perfect e Perfective" (perfeito e perfectivo) são dois aspectos distintos para Comrie. $\mathrm{O}$ "perfeito" incluiria uma ligação com o presente que não há no perfectivo
} 
O aspecto verbal no Português: a categoria e sua expressão 


\section{3 - Tipos de situação}

No estudo do aspecto, é importante a consideração de determinados tipos de situação por três razões principais:

a. em primeiro lugar, porque a combinação de diferentes tipos de situação com uma mesma flexão temporal ou tipo de perífrase verbal, por exemplo, pode resultar na expressão de diferentes aspectos; ${ }^{1}$

b. em segundo lugar, porque as propriedades semânticas inerentes (aspectuais ou não) dos diferentes tipos de situação interagem com as oposições aspectuais, proibindo certas combinações ou restringindo severamente os significados das combinações;

c. em terceiro lugar, a consideração de certos tipos de situação facilita a resolução de problemas de interpretação e determinação do aspecto presente em muitos casos problemáticos.

Nesta seção vamos tratar apenas de alguns tipos mais gerais de situação e cujo efeito no aspecto não é restrito. Os tipos de situação cujo efeito é restrito serão colocados no momento que se fizerem necessários.

\section{1 - VERBOS TÉLICOS E ATÉLICOS²}

Verbo télico é aquele que indica uma situação que necessariamente chega a um fim, ou seja, uma situação que marcha para um clímax ou ponto terminal natural. Exemplos:

\footnotetext{
${ }^{1}$ Sobre as formas de expressão do aspecto e elementos da frase que têm influência no aspecto que se expressa, veja principalmente a parte II.

${ }^{2}$ Castilho (1967) e Comrie (1976) falam de verbos télicos e atélicos tal como os definimos aqui.
} 
89. decidir, fazer uma cadeira, morrer, nascer, explodir, engolir, etc.

Verbo atélico é aquele que indica uma situação que não tende a um fim necessário. Exemplos:

90. cantar, chover, ler, caminhar, mastigar, andar, etc.

No verbo télico a situação não termina antes de chegar neste ponto terminal necessário, ou seja, se para a situação antes de chegar ao término necessário, ela terá sido interrompida antes de ser concluída e uma afirmação como (91) seria falsa.

\section{João fez uma cadeira.}

Já no verbo atélico, se para a situação, a afirmação com o verbo no pretérito perfeito do indicativo, como (92), seria verdadeira independentemente de quanto João leu, se leu uma obra completa ou não.

\section{João leu.}

Do que se expôs acima podemos deduzir o seguinte teste para verificar se um verbo é télico ou atélico:

Se a frase com a perífrase "ESTÁ + GERÚNDIO do verbo em questão" não implica a frase com o verbo no pretérito perfeito do indicativo, o verbo é télico; mas, se implica, então o verbo é atélico. Exemplos:

93. "João está fazendo uma cadeira" não implica que "João fez uma cadeira"e, então, o verbo é télico.

94. "João está caminhando" implica que "João caminhou" e então o verbo é atélico.

Este teste não funciona bem com verbos de estado e nem com verbos do tipo de "saber" e "estar em". ${ }^{3}$ O teste é um pouco estranho com verbos como "respirar"

\footnotetext{
${ }^{3}$ Outros verbos que parecem se incluir nessa classe são: conter ( $\mathrm{O}$ vaso contém 3 flores), possuir, necessitar, precisar (Eu preciso de um lápis), carecer, conhecer. Este grupo foi listado por Lobato (1975, p.34) sob a classificação de "verbos de estado" sem explicar o porquê da classificação. (LOBATO, L. M. P. Os verbos auxiliares em português contemporâneo. In: . Análises linguísticas. Petrópolis: Vozes, 1975. p.27-91.).
} 
e "viver" que indicam processos contínuos concebidos como permanentes e que só se interrompem se deixa de existir o ser que o realizava ou em que ele se realizava. Com estes, todavia, dá para verificar que são atélicos.

Os verbos de estado e os verbos do tipo de "saber", "ter" podem todos ser considerados como pertencentes à classe dos verbos de estado (cf. nota 49), pois todos expressam situações não dinâmicas (cf. item 3.2) uniformes em todas as suas "fases de desenvolvimento". Como os verbos do tipo de "saber" não indicam estados propriamente ditos, propomos o nome de "verbos estáticos" para englobar verbos de estado e do tipo de "saber". Por indicarem situações que não têm um fim necessário, podemos dizer que os verbos estáticos são atélicos, todavia, como veremos, apresentam certos comportamentos idênticos aos verbos télicos. ${ }^{4}$

Como se pode facilmente observar, não podemos afirmar que um verbo seja apenas télico ou atélico, pois ele pode mudar de classe. Por exemplo, ler foi apresentado em (90) como um verbo atélico, mas na frase (95) ele funciona como télico, pois esta frase não implica que "João leu um livro".

\section{João está lendo um livro.}

Só encontramos exemplos de verbos atélicos que passam a télicos. Isto se dá, normalmente, pela influência de um complemento que é unitário, como em (95), ou que delimita uma quantidade ou medida que estabelece um fim necessário para a situação, como em (96a), ou pela influência de um adjunto adverbial (exemplo 96b).

96. a - João andará $3 \mathbf{~ K m}$ a pé. (João está andando $3 \mathrm{Km}$ não implica que João andou $3 \mathrm{Km}$ ).

b - João correu durante meia hora esta manhã.

É interessante observar que Castilho (1967, p.108) diz que é mais fácil o verbo passar de télico a atélico que vice-versa e registra que encontrou 20 exemplos do primeiro caso contra 6 do segundo. Portanto temos duas colocações contrárias: a que fizemos acima e a de Castilho. Acontece porém, que, como se pode facilmente observar, os verbos télicos indicam, normalmente, situações pontuais, ao passo que os atélicos indicam situações durativas. ${ }^{5}$ Isto é praticamente de regra, mas não ocorre sempre, pois temos situações durativas télicas, como por exemplo. "emol-

\footnotetext{
${ }^{4}$ Cf., por exemplo, a questão da indicação do aspecto acabado pelo pretérito perfeito do indicativo no item 7.3.

${ }^{5}$ Castilho (1967, p.55) diz que sempre os verbos télicos figuram uma ação ponto e que os atélicos figuram uma ação linha.
} 
durar", "ler um livro”, “andar 3 Km”, “cantar uma música”, “estudar a lição”. Não encontramos situações pontuais atélicas. Assim podemos dizer que:

a. situações pontuais $\rightarrow$ verbos télicos.

b. situações durativas $\rightarrow$ verbos normalmente atélicos, mas também télicos.

Como para Castilho todo verbo de situação pontual é télico e todo verbo de situação durativa é atélico, quando uma situação pontual é apresentada, como durativa ele diz que o verbo passou de télico a atélico daí o resultado que encontrou. Como, para nós, o que caracteriza o verbo como télico ou atélico é o tender ou não para um fim necessário, observamos a mudança de télico para atélico ou vice-versa relativamente a esta característica, daí termos chegado a uma conclusão oposta à de Castilho, pois realmente é mais comum um verbo passar de pontual a durativo do que vice-versa.

Disso tudo podemos tirar uma conclusão que será plenamente confirmada no estudo do aspecto no Português: a Língua Portuguesa tende a apresentar as situações mais como durativas do que como pontuais. Esta tendência é confirmada também pelo fato de os verbos atélicos (que sempre indicam situações durativas) serem mais numerosos do que os télicos ${ }^{6}$ (que normalmente indicam situações pontuais).

Vejamos, a título de exemplo, algo que mostre a importância da distinção entre verbo télico e atélico. Como explica Comrie (1976, p.46), quando combinados com os aspectos da oposição perfectivo/imperfectivo (Cf. item 4.2), as possibilidades semânticas dos verbos télicos são consideravelmente restritas, de modo que certas deduções lógicas podem ser feitas do aspecto de uma frase que se refere a uma situação télica, que não podem ser feitas do aspecto de uma frase que se refere a uma situação atélica. Assim, por exemplo, o perfectivo de uma situação télica implica que um ponto terminal da situação foi alcançado. Assim a frase:

97. João leu um livro.

implica que todo o livro foi lido e que a leitura foi concluída, enquanto que em

98. Pedro amou Maria.

\footnotetext{
${ }^{6}$ Castilho (1967, p.108) também afirma que os verbos atélicos são decidamente mais numerosos que os télicos, registrando que em seu estudo encontrou 121 verbos atélicos contra 45 télicos.
} 
Onde temos o perfectivo de um verbo atélico, não existe implicação de que algum ponto terminal tenha sido alcançado. Assim, perfectivo + télico implica que a situação acabou:

99. João decidiu não ir mais. (Implica que João não está mais decidindo)

Mas perfectivo + atélico não implica que a situação acabou: ${ }^{7}$

100. João correu. (Não implica necessariamente que João não está mais correndo)

Evidentemente uma modificação em (100), como o acréscimo de um adjunto adverbial, pode trazer a ideia de acabado. Veja o exemplo (101).

101. João correu nas Olimpíadas da Alemanha. (Aqui o adjunto adverbial faz com que se veja a situação como acabada).

\section{2 - SituAÇÃo DiNÂMICA E ESTÁticA ${ }^{8}$}

Na caracterização feita aqui o termo fase é usado para indicar uma situação em qualquer ponto de seu desenvolvimento, isto é, em qualquer ponto de TEMPO pelo qual ela dura, o que equivale a dizer em qualquer ponto do segmento de tempo AB da FIG. 1.

Temos uma situação estática quando as fases da situação são idênticas e uma situação dinâmica quando as fases da situação são diferentes, havendo, portanto, mudança de uma para outra fase. Essa oposição pode levar a algumas indecisões, pois poderão aparecer situações estáticas em que ocorram mudanças (como é o caso das indicadas por verbos do tipo de "saber" - cf. item 3.1), embora estas mudanças não sejam necessárias. Na situação dinâmica as mudanças são necessárias e obrigatórias. Desse modo, podemos dizer que na situação estática não há "input" constante de energia, enquanto na situação dinâmica há um "input" constante de energia por esforço interior (agentivo) ou exterior (não agentivo).

\footnotetext{
${ }^{7}$ Esse fato servirá como um argumento para mostrar que o aspecto perfectivo não pode ser definido como indicador de uma situação que se concluiu, acabada, pois aí temos forma perfectiva sem ter a ideia de acabado.

${ }^{8}$ Muito das ideias expostas neste item são de Comrie (1976, p.48-51), principalmente os conceitos de situação dinâmica e de estado e de processo e evento, bem como de Lyons (1977, p.707). Estes autores falam em estado e não em situação estática. Para nós, o primeiro é só um tipo da segunda.
} 
O começo e o fim da situação estática são dinâmicos já que envolvem mudança, isto é, diferença entre duas fases. Não há estados (ou qualquer situação estática) pontuais.

As situações dinâmicas podem ser subdivididas em:

a. processos, que são situações dinâmicas estendidas, que duram através do tempo, ou seja, situações dinâmicas durativas;

b. eventos, que são situações dinâmicas pontuais, momentâneas, não estendidas.

Eventos e processos, quando são controlados por agentes, são chamados respectivamente de atos e atividades. Exemplos.:

102. Processos: correr, mastigar, caminhar, assistir, ir.

103. Eventos: pular, bater, morrer, chegar, vencer, lembrar.

Lyons (1977, p.711-712) dá o nome de "accomplishment" ao processo télico (ler um livro, por exemplo) e de "achievement" ao evento télico (morrer, lembrarse, por exemplo). Achamos desnecessária a proposição dessa terminologia já que fica mais claro dizer "processo télico" e "evento télico" do que criar um nome para tais subclasses, pois isto obscurece o cruzamento das duas noções semânticas. Além disso, já dissemos não ter encontrado exemplo de evento (situação pontual) atélico, o que é também mostra da inutilidade desta terminologia, já que não há que distinguir evento télico de evento atélico.

As situações estáticas são como processos na medida em que duram ou perduram no tempo, mas diferem dos processos na medida em que são homogêneas, uniformes durante o período de sua existência. Situações estáticas não podem ser representadas como eventos.

Como vimos no item 3.1, os verbos de estado são apenas uma classe dos verbos de situação estática que se opõem aos verbos de situação dinâmica.

Como já dissemos, na situação pontual ou evento, o início, o meio e o término da situação "coincidem" ou, como preferem dizer alguns, a duração da situação é tão reduzida que os falantes a vêm como algo que ocorre momentaneamente, num ponto do tempo. Podemos ter três tipos de situações pontuais (eventos):

a. Situações pontuais inceptivas - são situações pontuais cuja ocorrência implica o início de uma outra situação que é durativa, ou seja, situações pontuais que são o início de uma situação durativa. Exemplos: 
104. O trem partiu. (E, em seguida, vai, corre, ou algo semelhante)

105. José adoeceu. (E, em seguida, está doente)

106. José começou a falar na segunda aula. (E, em seguida, fala)

b) Situações pontuais terminativas - são situações pontuais cuja ocorrência implica o término de uma outra situação que é durativa, isto é, situações pontuais que são o término de uma situação durativa. Exemplos:

107. Antônio chegou. (É o término de vir)

108. Maria venceu o concurso de beleza do clube. (É o término de disputar)

109. Rita terminou de limpar a casa às 11 horas. (É o término de limpar)

110. Eu achei o livro. (É o término de procurar)

$\mathrm{O}$ que se disse em a e b acima poderia ser representado graficamente da seguinte maneira:

FIGURA 2

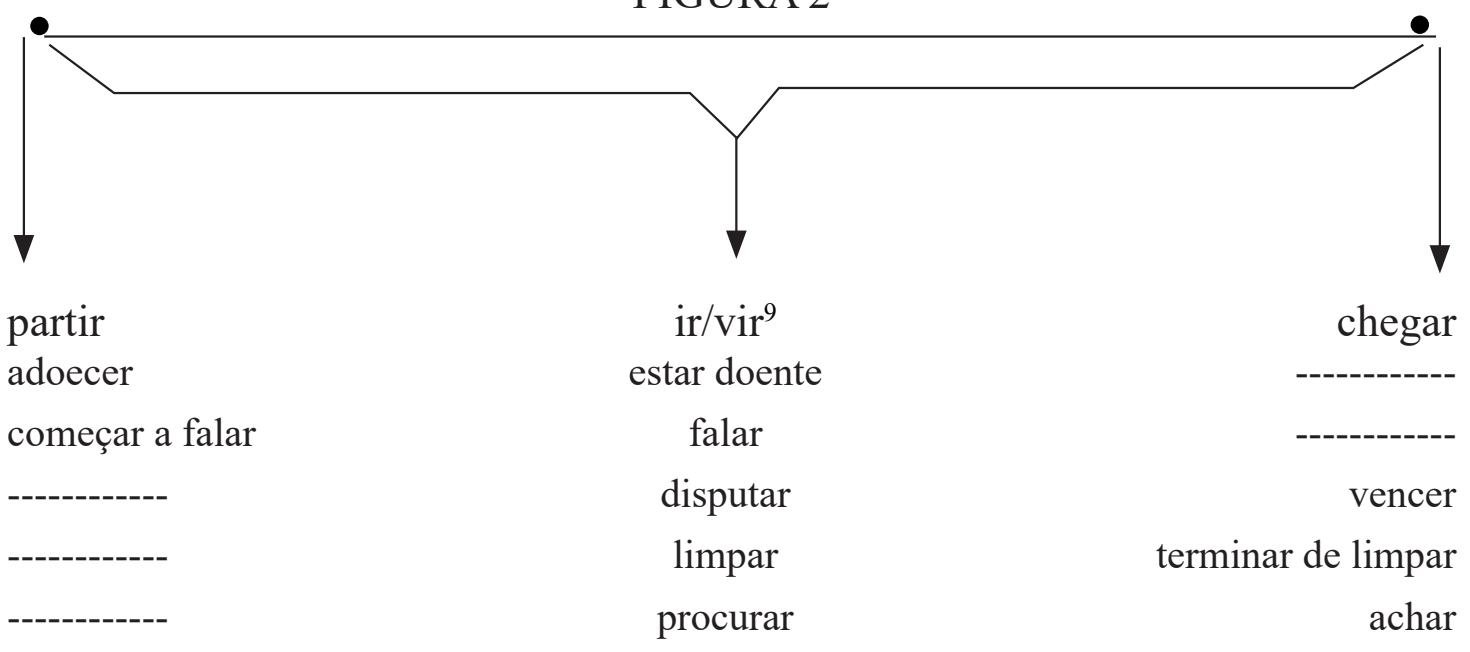

É interessante notar que o início e o término de uma situação em Português podem ser referidos de dois modos:

a. lexicalmente, por outro verbo;

b. por uma perífrase (na maioria dos casos).

\footnotetext{
${ }^{9}$ Aqui há dois verbos para a situação durativa, usados conforme a pessoa esteja no ponto de partida (ir) ou no ponto de chegada (vir).
} 
Assim temos por exemplo:

\begin{tabular}{c|c|c}
\multicolumn{3}{c}{ QUADRO II } \\
\hline INÍCIO & $\begin{array}{c}\text { PROCESSO OU } \\
\text { ESTADO }\end{array}$ & TÉRMINO \\
\hline partir & ir/vir & chegar \\
\hline nascer & viver & morrer \\
\hline começar a chorar & chorar & terminar de chorar \\
\hline principiar a estudar & estudar & \\
\hline adoecer & estar doente & vencer \\
\hline ficar doente & estar doente & achar \\
\hline começar a disputar & disputar & decidir \\
\hline começar a procurar & procurar & \\
\hline começar a pensar & pensar o que fazer & \\
\hline
\end{tabular}

Alguém poderia perguntar porque não apresentamos situações pontuais terminativas para os estados. Acontece que os verbos de mudança de estado do tipo de adoecer, sarar, emagrecer, clarear, etc. podem ser considerados tanto como inceptivos, quanto como terminativos, dependendo do ponto de vista em que nos colocamos. Exemplos:

$$
\begin{array}{cr}
\text { a - adoecer } & \begin{array}{r}
\text { - início do estado de doente } \\
\text { término do estado de são }
\end{array} \\
\text { b- emagrecer } & \begin{array}{r}
\text { - início do estado de magro } \\
\text { término do estado de gordo }
\end{array} \\
\text { c - sarar } & \text { - início do estado de são } \\
& \text { término do estado de doente }
\end{array}
$$

Assim sendo, poderíamos colocar o verbo "sarar" nos espaços vazios do quadro II, não o fizemos, entretanto, porque a intuição dos falantes vê esses verbos de mudança de estado sempre como inceptivos e, dessa forma, é melhor considerá-los como tais desprezando o fato de poderem ser tomados como terminativos. Parece que a língua não se preocupa em estabelecer situações pontuais terminativas para os estados possivelmente porque o fim de um estado representa, sempre, o 
início de outro e se prefere considerar o estado que inicia a considerar o estado que termina. Nem mesmo por meio de perífrases conseguimos estabelecer a situação cuja realização implica o término de um estado.

c. Situações pontuais que não são nem o princípio nem o fim de outra situação. Exemplos:

112. A bomba explodiu ao meio-dia.

113. O ladrão pulou o muro habilmente.

Os eventos, por serem situações pontuais, não deveriam, normalmente, ser usados com o aspecto imperfectivo, mas frequentemente o são para descrever a fase inicial ou final dos processos que se iniciam ou terminam com o evento que o verbo denota, ou para referir-se ao processo que conduz ao evento em questão ou ainda simplesmente, porque interessa apresentar o evento em seu desenvolvimento como se sua duração fosse ampliada num efeito de câmara lenta. Nestes casos, o falante apresenta a situação pontual como incompleta e durativa. Exemplos:

114. O rapaz está pulando o muro.

115. O trem está chegando.

116. O trem está partindo.

117. Os funcionários da companhia estão explodindo a ponte.

No exemplo (114) é como se tivéssemos um efeito de câmara lenta. Em (115) o que há é uma referência às últimas fases da situação que termina com a situação pontual de "chegar", isto é, o processo de vir. Com uma situação pontual inceptiva temos o mesmo efeito de (115), mas aí a referência é às primeiras fases do processo que se inicia com a situação pontual inceptiva, como ocorre em (116). Em (117) o que temos é a situação de preparação para a ocorrência da situação de explodir, e não propriamente a explosão; este modo de expressar é comum, uma vez que a língua frequentemente não tem um termo para referir-se ao processo que termina num dado evento. É como se estivéssemos dizendo em (117): "Os funcionários estão preparando para explodir a ponte".

Alguns exemplos mostrarão a importância da distinção dessas classes de verbos no estudo dos aspectos, explicando diferenças aspectuais em casos formalmente idênticos. Exemplos: 
A)

118. Evento + pretérito perfeito composto $=$ imperfectivo e iterativo

a) Tenho jurado falso.

b) Tenho engolido muito desaforo.

119. Processo télico + pretérito perfeito composto $=$ imperfectivo e iterativo.

a) Tenho lido bons livros.

120. Processo atélico uniforme em sua duração ${ }^{10}+$ pretérito perfeito composto $=$ imperfectivo e cursivo.

a) Tenho amado você e mais ninguém.

121. Processo atélico não uniforme em sua duração + pretérito perfeito composto $=$ imperfectivo e iterativo.

a) Tenho cantado em vários lugares.

B)

122. Verbo de situação estática + pretérito perfeito do indicativo $=$ perfectivo + acabado (cessativo).

a) Estive doente a semana passada.

b) Eu já soube matemática muito bem.

123. Processo atélico + pretérito perfeito do indicativo $=$ perfectivo (simplesmente).

a) $\mathrm{O}$ diretor pensou muito no problema

124. Evento de mudança de estado + pretérito perfeito do indicativo $=$ perfectivo.

a) José fez tantas extravagâncias que adoeceu.

É preciso lembrar ainda que, sendo durativos, os estados podem ser temporários (duração limitada) ou permanentes (duração ilimitada). Essa distinção aspectual para os estados é lexicalizada no Português por dois verbos: ser que indica estado permanente e estar que indica estado temporário. ${ }^{11}$ Exemplos:

125. José é doente. (permanente)

126. José está doente. (temporário)

\footnotetext{
${ }^{10}$ São verbos semelhantes a "saber", "ter". São processos uniformes em todas as suas fases de duração ou pelo menos sentidos como tais. É o caso dos verbos de sentimento: amar, odiar, etc.

${ }^{11}$ Cegalla (1976, p.226) aponta esta distinção dizendo que o verbo ser traduz aspecto permanente e o verbo estar, aspecto transitório. (CEGALLA, D. P. Novíssima gramática de língua portuguesa. São Paulo: Nacional, 1976.).
} 
Mesmo que se limite o período, o estado com o verbo ser é tomado como permanente no período considerado. Exemplo:

127. José foi muito doente até os 15 anos de idade.

Nem sempre a distinção entre evento e processo é fácil. Veja-se por exemplo, o caso dos verbos de mudança de estado (tais como adoecer, amarelar) e outros incoativos (como amanhecer) que podem ser vistos como eventos ou processos causando dificuldades na interpretação de fatos.

\section{3 - SitUAÇÃO NARRADA E SITUAÇÃO REFERENCIAL}

$\mathrm{Na}$ análise das noções aspectuais presentes em uma frase se nos deparam certos problemas que serão colocados a seu tempo e que nos levaram à proposição do que chamamos de situação narrada e situação referencial. ${ }^{12}$

Observem-se os exemplos abaixo (128 a 132) e também as frases (72) a (75) e(109).

128. O vaso está quebrado.

129. O conferencista começou a falar há meia hora.

130. Daniel tem o menino seguro em uma das mãos e olha para mim como a perguntar o que deve fazer.

131. Carla continuou caminhando pelo bosque, embora todos já tivessem voltado para casa.

132. A cozinha está por limpar.

Em todas estas frases notamos que a locução verbal se refere a duas situações e não a uma apenas: a situação que motivou o enunciado (que chamaremos de situação referencial) e uma outra situação (que chamaremos de situação narrada) relacionada a ela por uma das seguintes razões:

a. a situação referencial é um estado resultante da realização anterior da situação narrada, como é o caso nas frases (72) a (75), (128) e (130) ou um estado anterior à realização da situação narrada como em (132);

\footnotetext{
${ }^{12}$ Utilizamos a terminologia proposta por Bernardes Arruda (1978, p.49), embora nossa conceituação difira da sua, pois ela estabeleceu o conceito apenas para as construções de ESTAR + PARTICÍPIO. (BERNARDES ARRUDA, V. M. As passivas de estado e de mudança de estado em português contemporâneo. 1978. 130p. Dissertação (Mestrado em Linguística) - Universidade de Brasília, Brasília, DF, 1978.).
} 
b. a situação referencial é uma situação cuja realização implica o início ou o término de outra situação, que é a situação narrada. É o que se dá nos exemplos (109), em que a situação referencial é o término da narrada, e (129), em que a situação referencial é o início da narrada;

c. a situação referencial é uma situação cuja realização implica o prosseguimento da realização da situação narrada, cujo término era esperado por uma razão explícita ou não. É o que ocorre no exemplo (131).

A situação narrada pode ser anterior à situação referencial como nas frases (72) a (75), (109), (128) e (130), posterior como em (129) e em (132), anterior e posterior como em (131). Não há situação narrada e referencial simultâneas, pois neste caso uma única situação é a referencial e a narrada e não há porque nem como fazer a separação.

No exemplo (132) e semelhantes "por limpar" indica um estado anterior à realização da situação de limpar. ${ }^{13}$

Como veremos mais adiante, a ideia de situação referencial e situação narrada resolve certos problemas na análise dos aspectos presentes em frases construídas com perífrases; problemas estes que levaram autores como Castilho (1967), por exemplo, à criação de várias confusões.

A ideia de existir referência a duas situações na mesma perífrase não é tão nova assim. A ela se refere Said Ali (1971, p.159, $\S \S 809-815$, grifo nosso) ao falar do uso do particípio como predicativo com o verbo ter, por exemplo, em que o particípio indicaria "o estado resultante de um ato anterior". Todos os autores que falaram em aspecto permansivo ou resultativo como Câmara Júnior (1974b, p.142) (permansivo e resultativo) e Castilho (1967) (quando fala em perfectivo resultativo). Contudo estes autores aludiram à coisa sem explicitá-la e apenas com as perífrases de ESTAR + PARTICÍPIO e TER + PARTICÍPIO (= predicativo).

Estudando o problema das passivas de estado e de mudança de estado no Português contemporâneo, Bernardes Arruda (1978, p.42-50) coloca o problema e, à página 49, explicita:

“O Tempo verbal fixa uma relação entre o tempo da ação, que chamaremos de situação narrada, e o tempo do evento da fala, que chamaremos de to.

Já em (26)b

b. O cafezal está destruído pela geada.

\footnotetext{
${ }^{13}$ Dias (1970, p.231-232) diz que POR + INFINITIVO é empregado na qualidade de atributo, nome predicativo ou aposto, quando se fala do que ainda não está feito, do que ainda não se realizou. (DIAS, A. E. da S. Syntaxe historica portuguesa. Lisboa: Clássica, 1970.).
} 
Temos duas situações: uma é a situação narrada - "a destruição do cafezal" - que é anterior a to; a outra, que chamaremos de situação referencial, indica a permanência da situação narrada, relacionando-a com o tempo do evento da fala. A situação referencial em (26b) é simultânea a to".

Como já dissemos (cf. nota 58), nossa conceituação de situação narrada e referencial difere da que acabamos de transcrever. Primeiro por ser mais abrangente, já que, nos casos que observamos, nem sempre a situação referencial indica a permanência da situação narrada, relacionando-a com o tempo do evento da fala, embora isto ocorra no caso observado pela autora. Segundo, porque não podemos dizer que a situação narrada seja a ação em oposição à situação referencial que seria o estado resultante da ação, pois, embora isto seja válido para o caso observado por Bernardes Arruda, vimos que em outros casos a situação referencial pode ser uma ação, bem como a situação narrada.

A autora afirma que o que ocorre em seu exemplo (26b) transcrito acima é "um caso de Táxis", conceito sugerido por Jakobson e caracterizado por Woisetschlaeger como: "Taxis relates two situations, Tense fixes the time of a situation in relation to the time of the speech event". ${ }^{14}$ Isto deixa claro que a presença de duas situações (uma narrada e uma referencial), em uma dada forma verbal é, na verdade, a explicitação do relacionamento entre as duas.

A proposição do conceito de situação narrada e situação referencial não poderá ser considerada como algo "ad hoc", criado apenas para solucionar um problema surgido no estudo do aspecto, pois, como se pode ver em Bernardes Arruda (1978), tem outras motivações e explica outros fatos observados na estrutura da língua.

\footnotetext{
${ }^{14}$ WOISETSCHLAEGER, Erich F. A semantic theory of the english auxiliary system. Bloomington: Indiana University Lingustic Club, 1976. p.76 apud BERNARDES ARRUDA (1978).

"Taxis relaciona duas situações, o tempo fixa o momento da situação em relação ao momento de evento de fala"
} 
O aspecto verbal no Português: a categoria e sua expressão 


\section{4 - O quadro aspectual do Português}

\section{1 - DA IMPROPRIEDADE DE UM QUADRO DE ASPECTOS COMPOSTOS}

\subsection{1 - PRELIMINARES}

Conceituado o aspecto e determinadas as noções aspectuais, é preciso estabelecer um quadro aspectual, uma taxionomia dos aspectos. Nesta tarefa temos, basicamente, três possibilidades: estabelecer um quadro de aspectos compostos, um quadro de aspectos simples ou um quadro misto com aspectos simples e compostos.

Chamamos de compostos aqueles aspectos que são caracterizados por mais de uma noção aspectual. É o caso, por exemplo, do Perfectivo e Imperfectivo ${ }^{1}$ na definição que deles deram Castilho (1967) e Comrie (1976). Aspectos simples serão aqueles caracterizados por uma única noção aspectual. No quadro estabelecido por Câmara Jr. (cf. item 1.3.8) encontramos alguns exemplos de aspectos simples tais como o Inceptivo, o Inconcluso, o Pontual, entre outros.

$\mathrm{Na}$ argumentação a respeito da impropriedade dos aspectos compostos vamos nos valer, principalmente, do quadro proposto por Castilho (cf. item 1.3.9) não só por ser o único que fez um estudo mais sério do aspecto em Língua Portuguesa, mas também por ser o único que estabeleceu um quadro que busca dar conta de todos os casos possíveis em uma análise aspectual do Português.

\subsection{2 - Os ASPECTOS COMPOSTOS}

Procuraremos demonstrar aqui não só que um quadro de aspectos simples permite uma análise aspectual melhor, por ser mais simples e completa a análise

\footnotetext{
${ }^{1}$ Doravante, quando houver coincidência de terminologia, ao nos referirmos a um aspecto tal como definido por outros autores, ou a um aspecto que propomos para efeito de raciocínio, usaremos letra maiúscula; ao nos referirmos a um aspecto tomado como o definimos em nosso trabalho, usaremos letra minúscula.
} 
com um menor número de elementos; mas também uma série de impropriedades de análise que já deverão ser consideradas quando da proposição do quadro aspectual e sua aplicação na análise.

Para Castilho (1967), o perfectivo se caracteriza pela noção de completamento que ele entende como sinônima de acabamento uma vez que diz: "As nuanças decorrentes da ação totalmente decursa permitem subdividir o perfectivo em três tipos" (CASTILHO, 1967, p.50). Não há dúvidas quanto a isto já que Castilho o declara em diversas passagens: "Temos o aspecto perfectivo se se indica uma ação cumprida, contrária à noção de duração" (CASTILHO, 1967, p.14); “O perfectivo indica processo acabado" (CASTILHO, 1967, p.15). O perfectivo, para ele, também “designa a ação-ponto" (CASTILHO, 1967, p.54), já que o completamento "implica na indicação precisa do começo e do fim do processo, polos estes separados por um lapso de tempo extremamente curto e não significativo." (CASTILHO, 1967, p.50). Portanto o Perfectivo seria um aspecto composto caracterizado pelas noções de completamento (= acabamento) e pontualidade.

O imperfectivo é, pelo mesmo autor, caracterizado como sendo marcado pelo valor fundamental de duração (CASTILHO, 1967, p.49), indicando uma ação que dura (CASTILHO, 1967, p.41) uma ação-linha (CASTILHO, 1967, p.54). A duração apresentaria sempre um dentre três matizes (cf. item 1.3.9) que caracterizariam três subtipos: os aspectos Imperfectivo Inceptivo (noções de duração + início) Imperfectivo Cursivo (noções de duração + meio) e Imperfectivo Terminativo (noções de duração + fim). Portanto o Imperfectivo seria um aspecto composto em qualquer dos três subtipos que aparecesse.

Deve-se notar que ao caracterizar o Perfectivo e o Imperfectivo, Castilho não diz que este se caracteriza pelo não acabamento. Sua colocação faz pensar que ele opõe completamento no Perfectivo a duração no Imperfectivo, ou seja, podemos dizer que explicitamente Castilho não afirma que o Imperfectivo apresenta a ação como não acabada. Entretanto, pela oposição entre Perfectivo e Imperfectivo, isto parece ficar implícito.

Observem-se os exemplos abaixo, extraídos de Castilho (1967). Entre parênteses aparece o aspecto que ele disse estar presente na forma em negrito e a página de onde se extraiu o exemplo.

133. "Na sua voz irradiante começou logo a contar uma complicada história familiar, atravessada de traições, de direitos e de deveres". (Imperfectivo Inceptivo propriamente dito - p.63)

134. "Principiou a falar pausadamente, depois agitou-se, parecia um louco". (Imperfectivo Inceptivo propriamente dito - p.64) 
135. "Desatou a chorar convulsivamente". (Imperfectivo Inceptivo propriamente dito - p.65)

136. "Contemplou os seus livros com tanto afeto, como se em cada um estivesse uma página do seu coração". (Imperfectivo Cursivo propriamente dito - p.70)

137. "Firmina contou tudo. Como tinha sofrido coitadinho!" (Imperfectivo Cursivo propriamente dito - p.71)

138. "Há quase um século que correra sangue pelos seus campos". (Imperfectivo Cursivo propriamente dito - p.70)

139. "O patrão, que era um homem que gostava de fazer brincadeiras brutas, pensou, pensou, pensou e depois mandou recolher os pedintes". (Imperfectivo Cursivo propriamente dito - p.72)

140. "E foram que foram, andaram que andaram e chegaram na casa do pai de S. Francisco de Assis". (Imperfectivo Cursivo propriamente dito - p.72)

141. "À noite chamou a pequena e teve-a muito tempo apertada contra si”. (Imperfectivo Cursivo propriamente dito - p.72)

142. "Dois dias e duas noites lhe escutaram os passos invariáveis de cá para lá de lá para cá, nas salas desertas". (Imperfectivo Cursivo propriamente dito - p.72-73)

143. "Estivera desmaiado tão pouco tempo, mas no elevador me parecia que eu tinha regressado de uma longa morte". (Imperfectivo Cursivo propriamente dito - p.75)

144. "[...] foi a Balsa que lhe inoculou através dos anos a seiva que faria dela a mulher sã e formosa..." (Imperfectivo Cursivo propriamente dito - p.76)

145. "Dioclécio foi transformando Antônio Bento, descobrindo para o criado do padre um mundo novo". (Imperfectivo Cursivo progressivo - p.77)

146. "Ao tédio e ao desespero substituiu-se gradualmente na alma de Jorge estranha inquietação."(Imperfectivo Cursivo progressivo - p.78)

147. “A fita acabou e não falamos no incidente." (Imperfectivo Terminativo - p.79)

148. Terminada a festa, retiraram-se os convidados (Imperfectivo Terminativo - p.79)

149. "Só de ouvir dizer, porque, como acabo de contar, nunca os vira juntos." (Imperfectivo Terminativo - p.79-80) 
150. "[...] talvez porque lesse em meus olhos o que eu acabara de passar". (Imperfectivo Terminativo - p.80)

151. “Terminei de estudar a lição e saí à rua para espairecer”. (Imperfectivo Terminativo - p.80)

Nos exemplos (133) a (135) temos realmente uma duração "pressentida pelo falante" como diz Castilho. Acontece, porém, que essa duração não é das situações de "começar a contar", "principiar a falar" e "desatar a chorar" que são situações pontuais inceptivas (cf. item 3.2) e que nos exemplos aparecem como situações referenciais; a duração é das situações narradas (cf. item 3.3) "contar", "falar"e "chorar". Vemos assim que as formas sublinhadas nestes exemplos não podem ter aspecto Imperfectivo porque aí não há duração, mas pontualidade e, além disso, as situações referenciais são apresentadas como acabadas. ${ }^{2}$ Portanto nos exemplos (133) a (135) teríamos, na verdade, aspecto Perfectivo. É preciso considerar, entretanto, que as situações são apresentadas em seu ponto de início e, portanto, há incepção. Para analisar o aspecto destas frases teríamos, pois, de acrescentar ao quadro de aspectos compostos um Perfectivo Inceptivo, que estaria presente em frases onde tivéssemos eventos cujo completamento (= acabamento) implica o início de uma situação durativa. Com estes três exemplos pudemos ver além de uma impropriedade de análise, a necessidade de proposição de mais um aspecto composto.

Nos exemplos (136) a (146), abstraindo da questão de ser progressivo ou não, já que a progressividade é uma noção não aspectual, teríamos segundo Castilho, o Imperfectivo Cursivo, portanto, por definição, situações apresentadas durativamente e em seu pleno desenvolvimento (cf. item 1.3.9). Que se trata de situações durativas não podemos duvidar, pois em todos os exemplos temos processos; todavia é bom observar que nos exemplos (136) a (138) essa duração não é marcada gramaticalmente $^{3}$ como nos exemplos (139) e (140) (em que a duração é marcada pela repetição do verbo); (141), (142), (144), (146) (em que a duração é marcada pelo adjunto

\footnotetext{
${ }^{2}$ É importante não confundir situações referenciais e situações narradas, pois se isto ocorre, faremos análises falsas ou ficaremos diante de problemas de análise insolúveis.

${ }^{3}$ O próprio Castilho (1967, p.75), na nota 123, alerta contra a confusão que muitas vezes se faz entre categorias lógicas e gramaticais ao comentar que na frase "O dia vem vindo" há apenas a duração marcada pela perífrase e não há os valores incoativo e frequentativo que Eduardo Carlos Pereira anota para esta frase, com base em raciocínios tais como: a) "O dia vem vindo" equivale a "começa um novo dia" donde o valor "incoativo" (= inceptivo); b) como esse ato se processa diariamente temos o valor frequentativo". Nos exemplos (136) a (138) a duração é apenas deduzida do valor do verbo, porque, como veremos, a perífrase TER + PARTICÍPIO marca o acabamento e o completamento como os definimos no item 2.2.2.2 (ver no item 1.3.8 o que diz Câmara Júnior sobre esta perífrase) e o pretérito perfeito (ver item 7.3) marca apenas o completamento da situação apresentando-a em sua totalidade impenetrável à análise, sem excluir a duração, mas fazendo abstração da mesma, que, se necessário, tem de ser expressa por outro meio como um adjunto adverbial, por exemplo.
} 
adverbial); (143) e (145) (em que a duração é marcada por perífrases). Observe-se agora que em nenhum desses exemplos a situação é realmente apresentada "em seu pleno desenvolvimento": no exemplo (137) a perífrase TER + PARTICÍPIO marca a situação como acabada; nos exemplos (141) e (143) a situação é marcada como acabada porque temos verbos estáticos no pretérito perfeito do indicativo (cf. item 7.3); nos exemplos (138) e (142) a situação é apresentada como acabada respectivamente pelo pretérito mais-que-perfeito e pela combinação do verbo no pretérito perfeito do indicativo com um adjunto adverbial (Veja comentários em torno dos exemplos (96), (100) e (101) em 3.1); nos exemplos (139), (140) e (146) a situação é apresentada como acabada, porque o verbo está no pretérito perfeito e se apresenta o término da situação sublinhada: em (139) a decisão de mandar recolher, em (140) o chegar e em (146) a substituição de uma coisa por outra. Somente nos exemplos (136), (144) e (145) não podemos dizer que a situação seja acabada, embora também não possamos dizer o contrário. ${ }^{4}$

Diante das observações do parágrafo anterior pergunta-se: se as situações são apresentadas como acabadas, o aspecto presente nos exemplos (137) a (143) e (146) é o Perfectivo ou Imperfectivo? Se dissermos que é o Imperfectivo teremos o problema de explicar a presença do acabamento que caracteriza o Perfectivo; se dissermos que este último aspecto, teremos de admitir a existência de um Perfectivo durativo e fazer com que o Perfectivo seja caracterizado apenas pelo acabamento, passando a ser um aspecto simples. Se a duração deixar de ser exclusiva do aspecto Imperfectivo, temos de caracterizá-lo de uma outra forma e como ele é o aspecto que se opõe ao Perfectivo podemos dizer que seria caracterizado pela noção de não acabamento. A duração e a pontualidade passariam a caracterizar outros aspectos simples que poderíamos chamar de durativo e pontual, ou viriam a compor aspectos compostos com o Perfectivo e o Imperfectivo resultando 4 aspectos distintos. Como se pode ver, deparam-se nos aqui vários problemas de análise, quando propomos aspectos compostos e também alguns problemas de caracterização dos aspectos pelas noções aspectuais.

Examinemos agora os exemplos (147) a (151) em que Castilho diz haver o aspecto Imperfectivo Terminativo que, conforme ele afirma à página 79, aparece "quando a ação terminou após ter duração". Pela própria definição e pelos exemplos, vemos que a situação é apresentada como acabada e a duração aí não é gramaticalmente marcada, mas apenas pressentida, uma vez que temos processos deduzidos do substantivo sujeito (exemplo 147) ou indicados por este substantivo

\footnotetext{
${ }^{4}$ A situação nos três exemplos é apresentada como completa o que caracterizará a presença do aspecto que chamaremos de perfectivo.
} 
(exemplo 148) ou pelo verbo principal (exemplos 149, 150 e 151). Se a situação é apresentada como acabada não podemos dizer que o aspecto aí presente é o Imperfectivo apenas porque há duração, já que o acabamento ou completamento caracteriza o Perfectivo. Admitindo-se que nestes exemplos haja aspecto Perfectivo e que a duração é expressa ${ }^{5}$ poderíamos dizer que aí temos um Perfectivo Durativo. Isto seria lógico, pois Castilho diz que no exemplo (152) há aspecto Perfectivo Pontual e a única diferença do exemplo (152) em relação ao exemplo (149) é que no primeiro o verbo principal é um evento, portanto pontual, e no segundo é um processo, portanto durativo.

152. "Dr. Borges de Medeiros acaba de reconhecer a vitória do Dr. Júlio Prestes". (Perfectivo Pontual - p.85)

Não existe razão que leve a ignorar que tanto em (149) quanto em (152) existe acabamento e o fato de o verbo principal ser durativo ou pontual não é suficiente para classificar o aspecto em (149) de Imperfectivo e em (152) de Perfectivo. Todos estes fatos são mais evidências de que não se pode caracterizar o Perfectivo como acabado e pontual e o Imperfectivo pela duração. Como se disse anteriormente, parece que o Perfectivo tem que ser um aspecto simples caracterizado apenas pelo completamento (= acabamento) e o Imperfectivo pelo não completamento (= não acabamento).

Nos exemplos (149) a (151) acontece o mesmo que comentamos para os exemplos (133) a (135), mas agora temos terminatividade. A duração apontada aqui é das situações narradas "contar", "passar" e "estudar" e não das situações referenciais "acabar de contar", "acabar de passar" e "terminar de estudar" que são situações pontuais terminativas. Além disso as situações referenciais nas frases (149) a (151) são apresentadas como acabadas. Sendo apresentadas como acabadas e sendo pontuais, as situações das frases em questão não podem ter aspecto Imperfectivo, mas sim Perfectivo. Observe-se ainda que as situações são apresentadas em seu ponto de término e portanto há terminatividade. Para analisar o aspecto destas frases teríamos de acrescentar ao quadro de aspectos compostos um Perfectivo Terminativo, que estaria presente em frases onde tivéssemos eventos cujo completamento (= acabamento) implica o término de uma situação durativa. Com estes exemplos vimos mais alguns problemas de análise e a necessidade de propor mais um aspecto caso se pretenda manter um quadro de aspectos compostos.

\footnotetext{
${ }^{5}$ Dissemos que a duração nos exemplos em questão não é expressa gramaticalmente. Para efeito da classificação aspectual devemos considerar apenas as noções gramaticalmente expressas.
} 
Até agora vimos problemas ligados apenas a quatro noções aspectuais: a duração (considerada em si sem atentar para suas subdivisões - cf. quadro I em 2.2), a pontualidade, o acabamento e o não acabamento. Ao montar seu quadro aspectual, Castilho não levou em conta as noções aspectuais de situação completa e incompleta (cf. item 2.2.2.2). Consideremos a colocação destas noções no quadro aspectual.

Poder-se-ia inicialmente considerar o seguinte raciocínio: a situação completa terá aspecto Perfectivo, pois toda situação completa é acabada e vice-versa; enquanto a situação incompleta terá aspecto Imperfectivo, pois toda situação incompleta é não acabada e vice-versa. Embora pareça lógico e ocorra na maioria das vezes, o que dissemos não se verifica sempre. Vejamos alguns casos que evidenciam o fato de que acabamento e completamento e não acabamento e não completamento ${ }^{6}$ não coincidem necessariamente:

a. em primeiro lugar temos os casos em que a língua apresenta a situação como completa, e faz abstração da oposição acabado/não acabado não marcando a situação nem para uma nem para outra noção. É o que ocorre por exemplo com os verbos atélicos no pretérito perfeito do indicativo ${ }^{7}$ em que a situação é apresentada como completa, como um todo indivisível a exemplo do que ocorre nas frases (100), (136) e (145), mas não é também marcada gramaticalmente como acabada, a exemplo do que ocorre nas frases (97), (137), (141), (143), (149) e (150), em que temos as duas noções;

b. em segundo lugar temos casos em que a situação é apresentada como completa e não acabada (exemplo 153), e casos em que a situação é apresentada como incompleta e acabada (exemplo 154).

153. João sempre escreveu bem.

154. João sempre escrevia bem. ${ }^{8}$

Também em frases com verbos de estado e nas frases com verbos atélicos no pretérito imperfeito do indicativo e ênfase entonacional do verbo (Cf. nota 68),

\footnotetext{
${ }^{6}$ Atente-se para o fato de que completamento e acabamento estão sendo tomados agora não como sinônimos, mas no sentido em que foram definidos no item 2.2.2.2.

${ }^{7}$ Câmara Júnior (1970, p.90) ao dizer "no eixo da noção de aspecto opõe [o pretérito] dois conjuntos de formas verbais: um que assinala o processo inconcluso, ou imperfeito, outro, chamado "perfeito", é indiferente a essa assinalização" (grifo nosso) já observa que o pretérito perfeito não marca a situação como conclusa, acabada, entretanto não observou que isto ocorre apenas com os verbos atélicos. (CÂMARA JÚNIOR, J. M. Estrutura da língua portuguesa. Petrópolis: Vozes, 1970. 114 p.).

${ }^{8} \mathrm{Cf}$. argumentação em torno destes casos no item 7.3.
} 
temos exemplos em que a situação é apresentada como incompleta e acabada. É o que vemos em (155) e (156).

\section{João era professor.}

156. Pedro nadava muito.

Diante de tais evidências vemos que não podemos identificar completo e acabado, englobando-os no aspecto Perfectivo e nem incompleto a inacabado, englobando-os no aspecto Imperfectivo. Como o Perfectivo está sendo caracterizado pela noção de acabado e o Imperfectivo pela noção de inacabado ${ }^{9}$, temos de propor pelo menos mais dois aspectos compostos para dar conta da análise do aspecto nos exemplos (153) a (156): o Perfectivo (acabado) Incompleto (exemplos 154, 155 e 156) e o Imperfectivo Completo (exemplo 153). Como há frases em que temos as noções de acabado e completo juntas (exemplos 40, 58, 144) e outras em que temos inacabado e incompleto (exemplos 50 e 55), ter-se-ia de propor, respectivamente, os aspectos Perfectivo Completo e o Imperfectivo Incompleto. Este último, na verdade, teria de ser Imperfectivo Durativo Incompleto já que em (50) e (55) a duração também é marcada.

Como se está vendo, o número de aspectos compostos que temos de propor aumenta cada vez que descobrimos na análise aspectual uma nova combinação de noções aspectuais. Vejamos mais alguns casos.

No exemplo (145) temos marcadas as noções de duração e completamento, mas não a de acabamento. Assim sendo, temos de propor um aspecto Durativo Completo para estes casos que são distintos de frases semelhantes a (143) onde teríamos, em verdade, um Perfectivo (acabado) Durativo Completo. É interessante observar que, para um exemplo como (136), em que a situação não é marcada para as oposições acabado/não acabado e durativo/pontual, mas é apresentada como completa, temos de propor o aspecto simples Completo. Para um exemplo como (157), em que se faz abstração das oposições de acabado/não acabado e completo/ incompleto e só se marca a duração, necessitaremos de um aspecto simples Durativo para classificar o aspecto aí presente.

\section{João ficará atendendo as pessoas.}

\footnotetext{
${ }^{9}$ No quadro aspectual proposto no item 4.2, chamaremos de perfectivo e imperfectivo aspectos caracterizados por outras noções o que, naturalmente, levará a classificações diferentes da que apresentamos neste parágrafo e em outras passagens em que a mesma questão se verifica.
} 
Precisamos de um Imperfectivo Inceptivo para classificar o aspecto de uma frase como a do exemplo (44) e de um Imperfectivo Terminativo para o aspecto de uma frase como a do exemplo (51). Nos exemplos (48) e (158) as únicas noções aspectuais marcadas são, respectivamente, o momento de início e o momento de término das situações e, portanto, os aspectos aí só poderiam ser classificados por aspectos simples que poderíamos chamar de Inceptivo e de Terminativo.

\section{Maria terminará de embalar as louças às onze horas.}

Até agora, sempre que falamos em duração tratamos de duração contínua limitada. Se tomarmos exemplos em que aparece a duração descontínua limitada teremos novas combinações que levarão a aumentar ainda mais o quadro aspectual. Consideremos os exemplos (159) e (160):

159. Célia anda limpando a casa para mim.

160. Célia andou limpando a casa para mim.

Em (159) a situação é apresentada como não acabada e incompleta ${ }^{10}$, em (160) ela é apresentada como acabada e completa. As duas têm duração descontínua limitada. Podemos chamar de Imperfectivo Iterativo Incompleto o aspecto caracterizado pelas noções aspectuais presentes em (159) e de Perfectivo Iterativo Completo o aspecto caracterizado pelas noções presentes em (160).

Os exemplos examinados até agora deixaram claros alguns pontos: em primeiro lugar observamos que a cada nova noção aspectual que consideramos, novas combinações de noções se tornam possíveis, caracterizando diferentes aspectos compostos; em segundo lugar vemos que, embora as noções aspectuais apareçam combinadas nas frases, também aparecem isoladas; o que nos impede de propor um quadro aspectual apenas de aspectos compostos, levando-nos a propor um quadro aspectual misto; em terceiro lugar notamos que os aspectos compostos nada mais são do que diferentes combinações de aspectos simples tais como Perfectivo, Imperfectivo, Durativo, Pontual, Iterativo, Inceptivo, Terminativo, etc. Tendo em vista: a) que não se pode propor um quadro aspectual apenas de aspectos compostos; b) que os aspectos compostos são na verdade combinações de aspectos simples; c) e que se adotarmos um quadro misto de aspectos simples e aspectos compostos teremos de trabalhar com nada menos de quarenta aspectos, enquanto que um quadro de

\footnotetext{
${ }^{10}$ Não importa que cada realização da situação de limpar seja completa e acabada, para a classificação do aspecto aqui importa é a situação criada pela repetição da situação de limpar.
} 
aspectos simples nos dará apenas treze aspectos; podemos concluir que a proposição de um quadro de aspectos simples é melhor para a análise aspectual por eliminar terminologia cuja existência é desnecessária.

Uma vez alcançado o objetivo a que nos propusemos no início deste item, passemos à proposição do quadro aspectual do Português.

\section{2 - O QUADRO ASPECTUAL DO PORTUGUÊS}

\subsection{1 - PRELIMINARES}

Uma vez que já estabelecemos as noções aspectuais no item 2.2.2 e já verificamos que a melhor alternativa para a análise é a proposição de aspectos simples, isto é, caracterizados por uma única noção, torna-se fácil a criação do quadro de aspectos do Português.

Esclarecemos, desde já, que a terminologia que utilizamos, por vezes se encontra comprometida em outros trabalhos, identificando aspectos cuja caracterização é, frequentemente, bem diversa da do aspecto que aqui identificamos com o mesmo nome. Este é o caso, por exemplo, do aspecto indeterminado que tem caracterização muito diversa da dos aspectos que Castilho (1967) e Guillaume (1969) identificam pelo mesmo nome. Muitos casos semelhantes ocorrem e é preciso estar atento à caracterização que damos de cada aspecto para não criar confusões no momento da análise.

O quadro aspectual do Português está esquematizado no QUADRO III.

A seguir, falaremos de cada aspecto em particular, começando pelo perfectivo e imperfectivo, em virtude de serem os que estão marcados em quase todas as frases, com exceção de uns poucos casos que especificaremos no momento oportuno. Nos exemplos que apresentaremos só será considerado o aspecto em questão no momento, portanto, não faremos referência a outros que, porventura, possam estar presentes. Não nos ocuparemos em comentar caracterizações diferentes de aspectos que receberam o mesmo nome em outros trabalhos.

Neste item falaremos apenas o que se fizer necessário sobre a expressão dos aspectos já que esta questão é tratada especificamente na segunda parte. 


\section{QUADRO III}

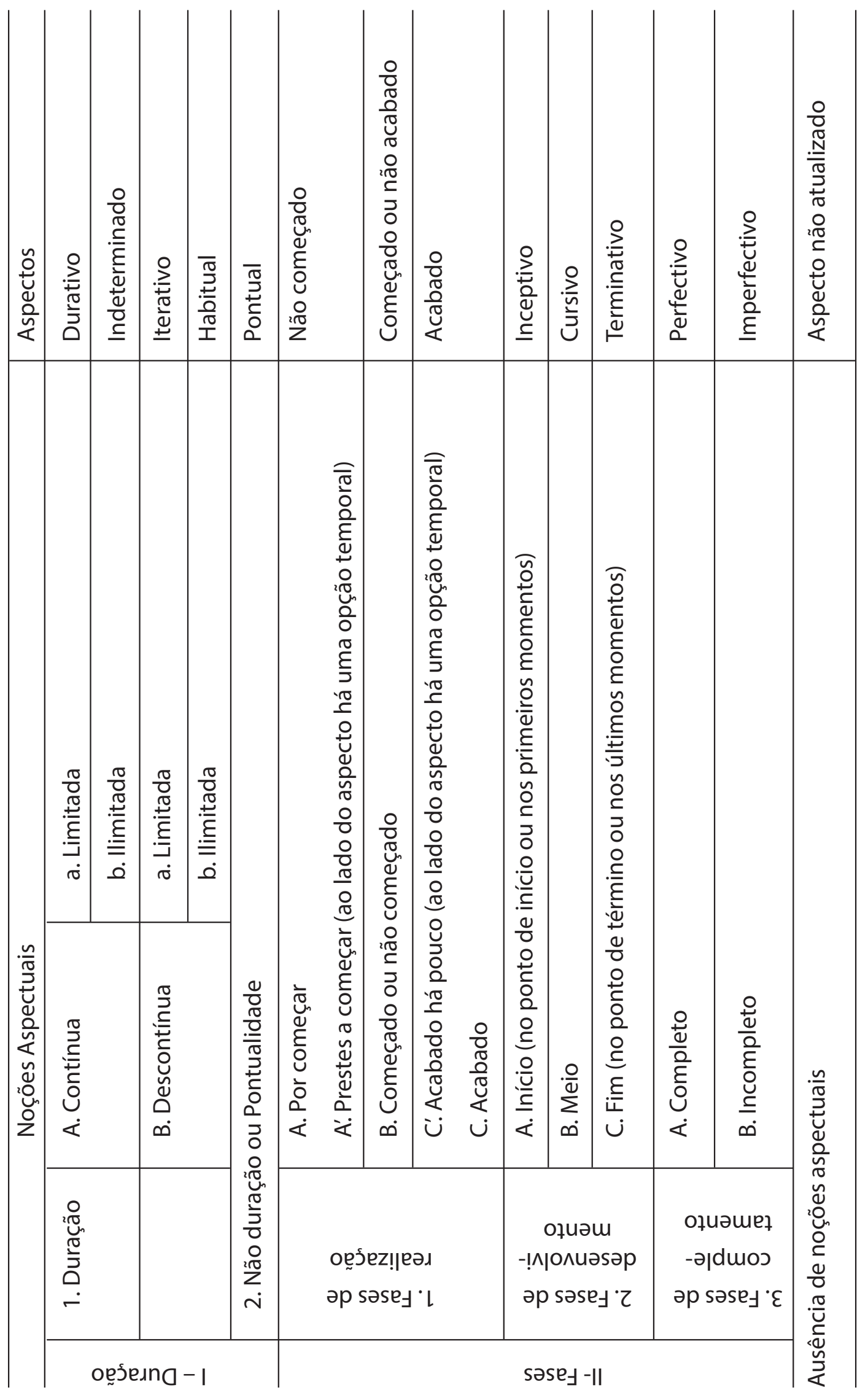




\subsection{2 - PeRfectivo}

O perfectivo é caracterizado por apresentar a situação como completa ${ }^{11}$, isto é, em sua totalidade. O todo da situação é apresentado como um todo único, inanalisável, com começo, meio e fim englobados juntos. Não há tentativa de dividir a situação em suas fases de desenvolvimento. É como se a situação fosse vista de fora, em sua globalidade.

Exemplos em que temos aspecto perfectivo podem ser encontrados nas frases de números (10), (37), (40) a (42), (46), (52), (56a), (57) a (60), (64), (69), (71), (76) a (86), (91) e (92), (97) a (101), (104) a (110), (112), (113), (122a, b), (123a), (124a), (127), (131), (133) a (147). Abaixo transcrevemos algumas destas frases.

10. Antônio ouviu música o dia todo.

41. Pedro pulara o muro com facilidade.

57. Célia andou indo ao cinema com Élio.

60. Maria ficou olhando as fotos durante várias horas.

82. Eu estive doente, por isso faltei a duas aulas.

Naturalmente estamos nos referindo às situações representadas pelos verbos em negrito em cada exemplo.

\subsection{3 - IMPERFECTIVO}

O imperfectivo é caracterizado por apresentar a situação como incompleta, isto é, não temos o todo da situação e, por isso, normalmente ela é apresentada em uma de suas fases de desenvolvimento. Isto equivale a dizer que, normalmente, a noção que caracteriza o aspecto imperfectivo aparece juntamente com as noções aspectuais representadas pelas fases de desenvolvimento da situação. Aqui, ao contrário do que ocorre no perfectivo, é como se a situação fosse vista de dentro, enfocando-se não o seu todo.

Podemos apontar como exemplo de frases em que temos aspecto imperfectivo as frases de número (8a, b), (9b), (11a-c), (20 a 29), (30a, b), (38), (39), (44), (45), (47), (49 a 51), (53), (54), (65), (67), (68), (70), (72 a 75), (95), (114) a (117), (118a, b), (119a), (120a), (121a), (128), (132), (159) e também os exemplos (161) a (165) abaixo.

\footnotetext{
${ }^{11}$ Comrie (1976, p.3, 18-19) também caracteriza o perfectivo como apresentando a situação em seu todo, completa, mas acrescenta a esta outras noções aspectuais.
} 
161. Estou escrevendo há dias e começo a sentir-me fatigado.

162. A competição iniciava-se naquele instante.

163. A festa terminava quando ele saiu.

164. Seus atos vêm escandalizando a todos.

165. A mistura ia endurecendo lentamente.

Antes de continuarmos a falar dos aspectos, queremos anotar que o aspecto perfectivo seleciona, para as frases em que aparece, adjuntos adverbiais de tempo que indicam momentos e períodos de tempo determinados e/ou completos (exemplos 166a, 167a, 168a, 169a), enquanto o imperfectivo aceita adjuntos adverbiais de tempo que indicam momentos e períodos de tempo indeterminados e/ou incompletos (exemplos 166b, 167b e 168b). Quando numa frase temos aspecto imperfectivo e adjunto adverbial de tempo que indica um período de tempo completo, a frase só será aceita num sentido iterativo e o período de tempo será indeterminado (exemplos 167b e 168b). Frases com aspecto imperfectivo só aceitam adjunto adverbial de tempo determinado se este indicar um momento no qual a situação já estava, está ou estará em desenvolvimento (exemplo 169b - ver nota 72), caso contrário o momento será indeterminado e a frase terá sentido iterativo (exemplos 170a,b).

166. a - Ricardo estudou há três dias. (É pontual e determinado) b - Ricardo estudava há três dias. (Havia já três dias que estava estudando - é incompleto).

167. a-Ricardo caminhou meia hora. (O período de tempo é completo e determinado: uma meia hora determinada).

b - Ricardo caminhava meia hora. (A frase só é válida no sentido iterativo em que cada realização da situação tem duração de meia hora - "meia hora" é indeterminado).

168. a-As samambaias brotaram em junho. (Um junho determinado). b - As samambaias brotavam em junho. (Junho é indeterminado e a frase só vale no sentido iterativo). ${ }^{12}$

169. a - $\mathrm{O}$ bebê nasceu às cinco horas. ("às cinco horas" é determinado) $\mathrm{b}$ - $\mathrm{O}$ bebê nascia às cinco horas. (A interpretação iterativa não sendo possível "as cinco horas" será tomado como determinado e a frase só será possível se interpretada como "O bebê estava nascendo às cinco horas").

170. a - Papai acordava às cinco horas. ("às cinco horas" é indeterminado e a frase tem interpretação iterativa).

${ }^{12}$ No exemplo (168b) se "em junho" for tomado como um momento determinado e não como um período a frase poderá ser aceita com o sentido de "As samambaias estavam brotando em junho". 
b - Mamãe dormia até às sete horas. (Só é possível na interpretação iterativa e "até às sete horas" é indeterminado, indicando o momento de término de cada realização da situação). ${ }^{13}$

\subsection{4 - Durativo}

O durativo é caracterizado por apresentar a situação como tendo duração contínua limitada.

São exemplos em que temos aspecto durativo as frases de números $(8 \mathrm{a}, \mathrm{b})$, (9a, b), (10), (11a, b), (38), (39), (42), (49), (55), (56b), (58), (60), (65), (67 a 75), (82), (120a), (122a), (126), (128), (131), (132), (139), (140), (143 a 146), (157). Abaixo transcrevemos cinco destas frases.

8a. Ele estava nadando desde as 6 horas da manhã.

42. O treinador do time esteve doente.

68. Nossa amizade estreitava-se.

69. O amor dos tios foi transformando aquela criança.

157. João ficará atendendo as pessoas.

Importa esclarecer que não se pode falar em aspecto durativo pelo simples fato de termos na frase um processo ou um estado que são situações durativas. É preciso ver se na frase em questão a situação está, por qualquer meio, marcada como durativa, pois, como já vimos, até mesmo situações pontuais podem ser apresentadas como durativas (cf. comentários em torno dos exemplos 114 a 117). Além disso, a forma verbal utilizada pode fazer abstração da oposição durativo/ pontual, não marcando a situação nem como uma nem como outra coisa, independente do fato de ser ou não um processo. É o que acontece, por exemplo, nas frases (40), (41), (43), (48), (59), (64), (76 a 79), (80), (83 a 86), (91), (92), (96), (97 a 101), (104), (106 a 110), (112), (113), (136 a 138), (147 a 151), na quase totalidade das quais temos processos, mas nenhuma marcação relativa à oposição aspectual durativo/pontual.

\footnotetext{
${ }^{13}$ Falaremos sobre a influência do aspecto na estruturação e interpretação de frases sempre nos pontos em que estivermos falando do elemento que afeta tal interpretação e estruturação.
} 


\subsection{5 - INDETERMINADO}

O indeterminado apresenta a situação como tendo duração contínua ilimitada. Temos este aspecto nos exemplos de número (12) a (19).

Como se pode ver pelos exemplos, ilimitado aqui não significa infinito, mas antes sem limites conhecidos ou perceptíveis, ainda que intuitivamente. Como já dissemos no item 2.2, as situações expressas em frases com aspecto indeterminado são atemporais ou antes onitemporais, já que são tomadas como elementos "universalizados", válidos para todo o tempo, que o falante torna válidos para o momento presente através de sua enunciação, mesmo que a situação não esteja ocorrendo no momento da fala. Assim se alguém diz, por exemplo, a um companheiro quando está viajando:

(171) Eu trabalho em uma loja de peças.

É evidente que a frase não tem a significação de "estou trabalhando agora na loja". O tempo sugerido é tanto o passado quanto o futuro e hipoteticamente o presente, isto é, a frase é onitemporal.

Como já ressaltamos no item 2.2, em consequência da pouca significação que apresenta para o espírito humano uma duração ilimitada, há uma tendência para ignorá-la total ou parcialmente. Isto apaga ou enfraquece a expressão do aspecto indeterminado, levando o verbo a referir-se só ou mais à situação em si já que o tempo também foi anulado. Isto quer dizer que a separação entre o indeterminado e o não aspecto é mínima e por vezes é difícil saber se temos um ou o outro.

Para nós o aspecto indeterminado não é, como para Castilho (1967), uma ausência de aspecto, embora admitamos que neste caso há um enfraquecimento da noção aspectual.

As frases que apresentam aspecto indeterminado têm basicamente as seguintes funções: ${ }^{14}$

a. apresentar verdades eternas ou tidas como tais. Estas verdades podem ser científicas (exemplos 12, 172 a 174), ou da experiência de vida que aparecem então sob a forma de máximas, provérbios ou simples afirmações de caráter geral (exemplos 13, 15, 175 a 177) ou teológicas, metafísicas, religiosas (exemplos 16 e 17), etc.

\footnotetext{
${ }^{14}$ Castilho (1967, p.102-106) e IMBS (1960, p.24-30) também comentam as funções das frases que apresentam este aspecto.
} 
172. Os ângulos internos do triângulo somam 180 graus.

173. O ano tem 365 dias.

174. Os corpos se atraem na razão direta das massas e na razão inversa do quadrado da distância.

175. Macaco velho não põe a mão em cumbuca.

176. Nunca somos suficientemente prudentes.

177. Só um louco ri da desgraça alheia.

b. Caracterizar seres ou coisas. ${ }^{15}$ Exemplos (14), (18), (19), (178 a 182)

178. Esta obra apresenta o homem feliz.

179. João é um rapaz inteligente.

180. A zebra é herbívora.

181. A onça ataca, quando está faminta.

182. Maria fala cinco línguas.

Em exemplos como (14), (181) e (182) a característica é apresentada como uma disposição, uma habilidade ou capacidade para realizar a ação. No exemplo (181) temos uma caracterização no limite do habitual que comentaremos ao falar deste aspecto.

c) Definir seres e coisas. Exemplos:

183. Lâmpada - objeto que serve para iluminar.

184. Música - Arte através da qual se combinam os sons de modo agradável ao ouvido.

185. Musicado - que se desenrola ao som da música.

\subsection{6 - ITERATIVO}

O iterativo se caracteriza por apresentar a situação como tendo duração descontínua limitada. Veja-se no item 2.2.2.1 o que falamos sobre duração descontínua.

São exemplos de frases em que temos o aspecto iterativo as frases de números (11c), (21 a 24), (30-b), (57), (118a, b), (119a), (121a), (159), (160) e também os exemplos (186) a (188) abaixo.

\footnotetext{
${ }^{15}$ É em virtude dessa função que Joos (1968, p.110-111) chama o aspecto presente nestas frases de "characterizing generic aspect" (aspecto genérico caracterizador). (JOOS, M. The english verb: form and meanings. London: University of Wisconsin Press, 1968. 251 p.).
} 
186. "Nosso filólogo andou falhando no começo do ano". (Ciro dos Anjos)

187. Ela me acenou várias vezes.

188. As crianças ora choravam, ora brincavam. ${ }^{16}$

O modo de repetição normalmente é marcado por meios lexicais: a repetição alternada é marcada por conjunções coordenativas alternativas (exemplo 188); a frequência de repetição é marcada por adjuntos adverbiais tais como "muitas vezes", “algumas vezes", "seguidamente", "raramente", "sempre", etc. que de uma certa forma também quantificam a repetição; a regularidade da repetição também é marcada por adjuntos adverbiais tais como "todos os dias" (exemplo 20), "de tempos em tempos" (exemplo 23), "aos domingos" (exemplos 30a, b), "duas vezes por semana", "sempre à mesma hora", "cada manhã”, etc.; a negação de repetição regular é marcada por expressões adverbiais ao mesmo tempo negativas e temporais como "nunca" (exemplo 28), "não [...] jamais" (exemplo 189), "nem sempre" (exemplo 190), jamais, etc.

189. Mariana não escuta jamais os conselhos que lhe dão.

190. Nem sempre o diretor começa a atender às oito horas.

Como já ressaltamos no item 2.2 os adjuntos adverbiais marcadores de iteração e de sentido totalizador tais como "todos os dias", "sempre", "nunca", “invariavelmente" etc. são mais utilizados nas frases de sentido iterativo habitual.

A exemplo do que acontece com o aspecto durativo, para dizermos que em dada frase temos aspecto iterativo, é preciso que a repetição criada pela duração descontínua limitada esteja marcada gramaticalmente. Assim, por exemplo, nas frases em que temos verbos que indicam situações intrinsecamente iterativas tais como "saltitar" (dar pequenos e repetidos saltos), "cuspinhar" (cuspir a miúdo e pouco de cada vez), "repicar" (tanger repetidas vezes); não teremos aspecto iterativo simplesmente pela presença de tais verbos na frase (cf. também item 9.3.2), como também não temos aspecto durativo simplesmente por ter um processo na frase. Assim, nas frases (191) a (193) não temos aspecto iterativo, porque este não está marcado por nenhum elemento da frase, enquanto nas frases (194) a (196) há aspecto iterativo marcado pelas perífrases. ${ }^{17}$

\footnotetext{
${ }^{16}$ Exemplo (186) apud Castilho (1967, p.98). Exemplo (188) é de Castilho (1967, p.60).

${ }^{17}$ Cf. capítulo 8 .
} 
191. A menina saltitava de alegria quando entrei na sala.

192. Maria veio da cozinha cuspinhando para expulsar da boca o gosto amargo do remédio que tomara.

193. O sacristão está repicando o sino para chamar o povo à festa.

194. Minha filha tem saltitado como um cabritinho feliz.

195. Aquele velho anda cuspinhando em toda a casa.

196. O padre tem repicado o sino todas as tardes para lembrar ao povo seus deveres religiosos.

\subsection{7 - HABITUAL}

O habitual ${ }^{18}$ é o aspecto que apresenta a situação como tendo duração descontínua ilimitada. (cf. item 2.2.2.1 o que falamos sobre duração descontínua).

Temos aspecto habitual nos exemplos de números (20), (25 a 29), (30a), (153) e (197 a 203) abaixo.

197. Sempre que chegavam visitas, mamãe fazia biscoitos fritos.

198. Ele usava fumar após as refeições.

199. Todas as manhãs ela me cumprimenta com um sorriso.

200. Se fica sem dormir ela adoece.

201. Embora papai costumasse chegar às seis horas em casa, nunca jantamos antes das oito.

202. Embora Valdete viva caminhando pelo bosque, não conhece todos os seus recantos.

203. Quando fica nervoso, Rafael desata a engolir tudo o que é comestível que encontra pela frente.

Considerando o fato de que a habitualidade não é uma noção aspectual, poderse-ia propor a reunião dos aspectos iterativo e habitual num só aspecto já que ambos se caracterizam basicamente pela repetição originada da duração descontínua. Isto, entretanto, implicaria desconsiderar a distinção entre duração limitada e ilimitada, que é real, representando duas noções aspectuais distintas.

Como já dissemos no item 2.2.2.1, as frases em que temos aspecto habitual, em virtude de duração ilimitada deste, podem ser usadas com a função de caracterizar

\footnotetext{
${ }^{18}$ Já dissemos no item 2.3 que a habitualidade não é uma noção aspectual, mas sim a duração descontínua ilimitada de que ela resulta.
} 
seres ou coisas, exatamente do mesmo modo que as frases em que temos aspecto indeterminado. Como nestas, aqui também temos a mesma onitemporalidade, principalmente com o verbo no presente do indicativo. Vejam-se os exemplos (31 a 33) e (204 a 207).

204. Paulo fuma muito.

205. As crianças gostam de animais.

206. Hélio deixa de ir trabalhar por qualquer problema que surja.

207. Ivo sempre começa o trabalho com má vontade, mas depois se entusiasma.

Como a única distinção entre o aspecto indeterminado e o habitual é a duração ser contínua ou descontínua, em algumas frases com mesma função torna-se difícil, na análise, perceber se temos um ou outro aspecto. É o que acontece, por exemplo, nas frases (208) e (209). Na verdade estes casos parecem ser limítrofes entre um e outro aspecto.

208. Se a quantidade de luz aumenta, os brotos começam a morrer. (Aqui parece haver uma maior tendência para o aspecto indeterminado).

209. Quando a quantidade de luz aumenta, os brotos começam a morrer. (Aqui parece haver uma maior tendência para o aspecto habitual).

Quando temos o aspecto habitual, naturalmente temos várias realizações da mesma situação. É comum que a língua atribua a cada realização da situação um determinado aspecto. Pode-se observar isto nos exemplos (210) a (214) abaixo, onde, entre parênteses, especificamos o aspecto ou os aspectos com que cada realização da situação habitual é apresentada.

210.) Todo dia, quando chego, Verinha está batendo a máquina. Imperfectivo, cursivo, não acabado, durativo) - o fato de Verinha estar batendo a máquina quando chego é habitual e portanto se repete, tendo aspecto imperfectivo, habitual e não acabado.

211. Ele começa a treinar sempre às 6 da manhã. (Imperfectivo, inceptivo).

212. Às 6 horas, o chefe de seção de pessoal sempre está conferindo o ponto. (Imperfectivo, cursivo, durativo, não acabado). 
213. João normalmente ia rabiscando um papel enquanto conversava. (Imperfectivo, durativo).

214. Sempre que chego em casa meu filho está terminando de fazer os deveres. (Imperfectivo, terminativo, não acabado).

Nestes casos, ao fazer a análise aspectual, é preciso não confundir o aspecto da situação única criada pela repetição com o aspecto atribuído a cada realização da situação. Importa notar que, nestes casos, normalmente a habitualidade é marcada ou condicionada por um elemento adverbial, seja um adjunto, seja uma oração. No aspecto iterativo o mesmo fato se dá, embora pareça ser menos frequente.

\subsection{8 - PONTUAL}

O aspecto pontual é caracterizado por apresentar a situação como pontual, ou seja, como não tendo duração. Logicamente toda situação tem duração, mas, linguisticamente, a duração só é considerada quando é expressiva (cf. nota 30). Já dissemos no item 3.1 que o Português tende a apresentar as situações mais como durativas do que como pontuais, daí encontrarmos um número bem maior de frases com aspecto durativo do que com aspecto pontual e também um menor número de elementos marcadores de aspecto pontual.

Os dois casos de expressão do aspecto pontual que parecem ser mais frequentes no Português ocorrem com o presente do indicativo nos seus usos denominados de "presente momentâneo" (exemplos 215 a 217) e "presente histórico ou narrativo" (exemplos 218 a 220). O pontual com o presente momentâneo só ocorre com verbos de evento, pois com verbos de processo ou estado teremos habitual ou cursivo; ${ }^{19}$ e também em descrições simultâneas, isto é, quando falamos da situação no exato momento em que ela ocorre. Se não tivermos uma descrição simultânea, as frases de presente do indicativo e aspecto pontual serão automaticamente interpretadas como de presente histórico que, na verdade, cria o efeito estilístico de alguém que narra o fato no instante em que ele ocorre, como numa descrição simultânea, ou então será visto como habitual.

215. Raulzinho pega a bola e atira para Roberto. (Dito pelo locutor que irradia um jogo).

216. Os carros partem neste instante com Fittipaldi à frente. (Na irradiação de uma corrida).

\footnotetext{
${ }^{19}$ Como veremos no capítulo 5, o aspecto pontual é incompatível com o habitual e o cursivo.
} 
217. Pedro chega na sala e descobre angustiado que sua mãe está morta. (Dito, por exemplo, por alguém que vê um filme e comenta as cenas, digamos, numa aula).

218. O Visconde de Mauá funda estaleiros e inicia no Brasil a construção naval.

219. Caxias ataca o inimigo e vence-o.

220. Desconsiderado em sua terra, Marcos vai para o Rio, estuda e, anos mais tarde, quando volta, se surpreende com o tratamento que lhe dispensavam.

Embora nem sempre isto ocorra, o uso do pretérito perfeito do indicativo pode resultar em frases com aspecto pontual. Veja os exemplos (221) e (222):

221. Um dia Mariana descobriu o que podia fazer com o dinheiro.

222. Achei seu anel dentro da gaveta do criado.

Somente o pretérito perfeito do indicativo de verbos que indicam situações estritamente pontuais é que marca o aspecto pontual. ${ }^{20}$

A presença ou não do aspecto pontual pode ser detectada pela possibilidade ou não de colocação na frase de um adjunto adverbial durativo. Se pudermos colocar na frase um adjunto adverbial de tempo indicador de duração é porque aí não temos aspecto pontual marcado. Não se pode inferir também que se tenha aspecto durativo, pois se a mesma frase aceitar um adjunto adverbial de tempo pontual é porque a situação da frase não é marcada para a oposição pontual/durativo, havendo abstração da duração. Verkuyl (1972) já aponta esta restrição de seleção entre o aspecto e o adjunto adverbial, mostrando para o alemão que uma frase com aspecto durativo só aceita adjunto adverbial de duração e que a frase com aspecto pontual só aceita adjunto adverbial pontual. Só isso pode explicar a agramaticalidade de uma frase como (223).

223. * Achei seu anel dentro da gaveta do criado durante cinco minutos.

Deve-se ter em mente que o adjunto adverbial usado para detectar a presença do aspecto pontual ou durativo deve indicar o tempo de realização da situação, o seu tempo de ocorrência, ou o teste não será válido, pois, quando o adjunto adverbial

\footnotetext{
${ }^{20}$ Sobre a indicação do aspecto pontual pelo pretérito perfeito do indicativo veja também o que dizemos no item 7.3.
} 
pontual indica um dos momentos em que a situação está, estava ou estará se dando, podemos ter um adjunto adverbial pontual com aspecto durativo como em (224).

224. Às duas horas Maria ainda estava estudando.

É comum no estudo do aspecto dizer-se que o perfectivo apresenta a situação como pontual. Se assim fosse, em todas as frases em que tivéssemos perfectivo não poderíamos ter adjuntos adverbiais de duração, mas não é isso o que ocorre, como se pode ver pelos exemplos $(225 \mathrm{a}, \mathrm{b})$ e $(226 \mathrm{a}, \mathrm{b})$ em que temos, com a mesma forma perfectiva, adjuntos adverbiais tanto durativos quanto pontuais.

\section{5. $\mathrm{a}$ - João correu às quinze horas. b - José correu durante trinta minutos.}

226. a - Maria conversou comigo às nove horas. b - Maria conversou comigo por muito tempo.

Além disto, o aspecto perfectivo, muito frequentemente, aparece combinado ao durativo, como se pode ver nas frases (10), (42), (58), (60), (69), (71), (82), (122a), (139), (140), (143), (144) e (146). Isto deixa claro que a forma perfectiva não é, necessariamente, também pontual.

Considerando que o aspecto pontual apresenta a situação como não tendo duração e, portanto com o início, meio e fim coincidentes, vemos que é impossível apresentar uma situação com aspecto pontual, como incompleta. Isto significa que toda situação com aspecto pontual terá de ser apresentada como completa, isto é, com aspecto perfectivo. Fica assim esclarecida a relação entre o perfectivo e o pontual: não é todo perfectivo que é pontual, como normalmente se diz; mas todo pontual é que é perfectivo.

A diferença entre frases como (215 a 220) e (221), (222) é que nestas temos aspectos pontual, perfectivo e acabado marcados, enquanto nas primeiras temos marcados apenas os aspectos perfectivo e pontual, havendo pois abstração da distinção acabado/não acabado.

\subsection{9 - NÃO COMEÇADO}

O aspecto não começado se caracteriza por apresentar a situação na fase anterior ao início de sua realização, portanto como algo por começar. Depreende-se da frase em que ocorre tal aspecto que há ou houve "intenção" ou "certeza" de a situação se realizar. As frases de números (7c), (34 a 37) e (132) são exemplos em que temos este aspecto. Abaixo transcrevemos três destes exemplos: 
35. Pedro está para emoldurar o quadro.

37. Este livro ficou por ler, pois não tive tempo.

132. A cozinha está por limpar.

Como se pode observar, esse aspecto é normalmente marcado por perífrases: ESTAR + PARA (ou POR) + INFINITIVO e FICAR + POR + INFINITIVO, etc.

Alguém poderia argumentar que o que temos aqui é uma marcação de futuro e não de uma fase da situação, que caracteriza um aspecto. Isto não é verdade pois, se assim fosse, teríamos de admitir que toda situação apresentada por uma forma de sentido futuro seria não começada e isto não ocorre. Em primeiro lugar, em frases como (227) a (229), não podemos garantir se a situação é começada ou não começada, isto é, não há marcação relativa a esta oposição. Nestes exemplos só podemos saber se a situação é começada ou não pelo conhecimento do mundo real.

227. O conferencista falará até às $22 \mathrm{~h}$ e 30 min. (Ele pode já estar falando ou não).

228. O médico acabará a operação antes de você chegar. (Ele pode já estar operando ou não).

229. Maria terminará de limpar a casa antes do almoço. (Ela pode já estar limpando ou não).

Em segundo lugar, podemos ter frases no futuro que têm marcado o aspecto começado, como é o caso dos exemplos (230) a (232).

230. Estará chovendo quando chegarmos ao Rio.

231. Quando vocês começarem a distribuir os folhetos continuarei falando.

232. Prosseguiremos lutando mesmo que alguns de nós sejam mortos.

Estes três casos são suficientes para demonstrar que tempo futuro e aspecto não começado são distintos e não devem ser confundidos, mesmo quando um só recurso é usado para assinalar os dois, como é o caso da perífrase ESTAR + PARA + INFINITIVO que marca aspecto não começado e futuro próximo (iminência de ação). Assim, não se deve confundir a ideia que se tem de futuro como algo não começado (o que nem sempre é verdade, como vimos), com a noção gramatical aspectual de não começado.

É preciso observar que com a perífrase ESTAR + POR + INFINITIVO o aspecto não começado é da situação narrada, pois a situação referencial que é um 
estado (ver comentários em torno do exemplo 132) terá um outro aspecto. Em (132), por exemplo, a situação referencial "está por limpar" tem aspectos imperfectivo, durativo, cursivo e não acabado, e a situação narrada "limpar" tem aspecto não começado. Ao fazermos a análise aspectual, é preciso estarmos atentos para este tipo de problema, pois sem a distinção entre as duas situações (narrada e referencial) estaríamos diante de um impasse, já que os aspectos cursivo e não começado são incompatíveis como veremos no capítulo 5 .

Não encontramos referência ao aspecto não começado em nenhum outro trabalho que trata do aspecto, especificamente ou não.

\subsubsection{0 - NÃO ACABADO OU COMEÇADO}

O aspecto começado ou não acabado se caracteriza por apresentar a situação já em realização, ou seja, após o seu momento de início e antes de seu momento de término. Portanto, se a situação é apresentada em seus primeiros ou últimos momentos, também temos o aspecto começado ou não acabado. São exemplos em que temos este aspecto, entre outras, as frases de números (8a, b) (11a-c), (20 a 25), (38), (39), (44), (47), (49 a 51), (53), (65), (67), (68), (70), (95), (114 a 121), (125), (126), (128), (130), (131), (159), (161 a 165), (166b), (191 a 196), (199), (202), (214), (230 a 232). Abaixo transcrevemos alguns destes exemplos.

11c. Minha cabeça tem doído muito.

38. Os rapazes continuam jogando apesar da chuva.

50. Estou lendo um livro interessante.

53. Raquel terminava de escrever a carta quando o telefone tocou.

126. José está doente.

164. Seus atos vêm escandalizando a todos.

A proposição de dois nomes para o mesmo aspecto se explica pelo fato de ele se opor a dois outros numa posição intermediária. Veja a este respeito o que dissemos no item 2.2.2.2 ao falarmos da fase que caracteriza este aspecto.

\subsubsection{1 - ACABADO}

O aspecto acabado se caracteriza por apresentar a situação após seu momento de término, portanto como concluída, acabada, terminada. Ele aparece, por exemplo, nas frases de números (7a), (40 a 43), (46), (52), (56a), (58), (59), (64), (71), (72 a 
75) $)^{21},(76$ a 79), (80 a 83), (91), (97), (99), (101), (104 a 110), (112), (113), (122a, b), (127), (133 a 135), (137 a 143), (146 a 152), (154). Abaixo transcrevemos os exemplos (40), (59), (71) e (149).

40. Maria leu o livro.

59. Quando eles voltarem, já terei preparado o lanche.

71. O pobre animal morreu pouco a pouco.

149. "Só de ouvir dizer, porque, como acabo de contar, nunca os vira juntos".

Muitas vezes a noção de situação acabada aparece sob a forma de cessamento (cf. item 2.3). Isto pode ser observado nos exemplos (42), (58), (80 a 84), (122a, b), (127), (141) e (143), alguns dos quais transcrevemos abaixo.

42. O treinador do time esteve doente.

58. A menina esteve balançando lá fora por muito tempo.

81. Eu, um dia, fui o maior malabarista do mundo.

122b. Eu já soube matemática muito bem.

\subsubsection{2 - INCEPTIVO}

$\mathrm{O}$ aspecto inceptivo se caracteriza por apresentar a situação em seu ponto de início ou em seus primeiros momentos. No segundo caso ele é mais facilmente perceptível. Podemos observá-lo nas frases de números (44 a 48), (106), (133 a 135), (161 - a 2 $2^{\text {a }}$ locução), (162), algumas das quais transcrevemos abaixo.

44. Os marceneiros estão começando a armar o telhado.

47. Daniel principiava a arrumar a mala quando cheguei em sua casa hoje de manhã.

48. Jorge começará a soltar os fogos de artifício às 20 horas.

106. José começou a falar na segunda aula.

161. Estou escrevendo há dias e começo a sentir-me fatigado.

\footnotetext{
${ }^{21}$ Em frases como estas o aspecto acabado é da situação narrada e não da referencial. Veja o que dizemos a este respeito no item 5.2.
} 


\subsubsection{3 - CuRSIVO}

$\mathrm{O}$ aspecto cursivo se caracteriza por apresentar a situação em pleno desenvolvimento, ou seja, concebida como já tendo passado seus primeiros momentos e ainda não tendo atingido seus últimos momentos. Em outras palavras, a situação é apresentada na fase do meio de seu desenvolvimento.

São exemplos em que temos este aspecto, entre outras, as frases de números (8a, b), (11a, b), (34), (38), (39), (49), (50), (55), (65), (67), (68), (70), (72 a 75), (95), (114 a 117), (120a), (126), (128), (130), (132), (164), (165), (191 a 193) e (230 a 232). Abaixo transcrevemos algumas.

11) a - José lia um romance quando sua irmã chegou.

b - Estamos fazendo um bolo para mamãe.

38. Os rapazes continuam jogando apesar da chuva.

55. O presidente estava falando desde as cinco horas.

65. A valente tropa fraquejava.

164. Seus atos vêm escandalizando a todos.

165. A mistura ia endurecendo lentamente.

192. Maria veio da cozinha cuspinhando para expulsar da boca o gosto amargo do remédio que tomara.

Pode parecer estranho falar que um estado se encontra em pleno desenvolvimento, e neste sentido, dizer que uma frase indicando estado tem aspecto cursivo, todavia a estranheza desaparece se lembrarmos que com isto estamos dizendo apenas que o estado existe e não está nem em seu início, nem em seu término. Temos aspecto cursivo quando a situação é um estado nas frases de números (72 a 75), (126), (128), (130), (132) e (233) abaixo, em que transcrevemos também dois dos exemplos citados.

72. Tenho a lição estudada.

75. Quando chegamos à fazenda o cafezal estava destruído.

233. Daniel está feliz com o novo emprego.

O que dissemos para os estados vale para qualquer situação expressa por um "verbo estático". Vejamos os exemplos (234) e (235) em que há aspecto cursivo.

234. Irene sabe matemática muito bem.

235. Oscar possui muitos bens. 
Também quando temos aspecto iterativo, devido à duração descontínua, pode parecer estranho falar em aspecto cursivo. Entretanto é preciso lembrar que estamos falando em cursividade da situação criada pela repetição e não de cada realização da situação que se repete. Temos aspecto cursivo ao lado do iterativo nas frases de números (11c), (21), (22), (24), (30b), (118a, b), (119a), (121a), (159), (188); duas das quais transcrevemos abaixo.

11c. Minha cabeça tem doído muito.

159. Célia anda limpando a casa para mim.

Normalmente não falaremos em cursivo quando tivermos iterativo ou habitual.

\subsubsection{4 - TERMINATIVO}

O aspecto terminativo se caracteriza por apresentar a situação nos seus últimos momentos ou em seu momento de término. Ele é percebido mais facilmente no primeiro caso. Podemos observá-lo nas frases de números (51 a 54), (109), (163), três das quais transcrevemos abaixo.

51. Espere um momento que estou acabando de arrematar seu vestido.

53. Raquel terminava de escrever a carta quando o telefone tocou.

109. Rita terminou de limpar a casa às 11 horas.

Não há aspecto terminativo em frases como (149), (150), (152) com a perífrase ACABAR + DE + INFINITIVO, pois aí a situação não é apresentada em seu ponto de término, mas alguns instantes após o mesmo. Transcrevemos a frase (152) abaixo.

152. "O Dr. Borges de Medeiros acaba de reconhecer a vitória do Dr. Júlio Prestes".

Cabe aqui uma observação sobre os aspectos inceptivo e terminativo e as situações pontuais inceptivas e terminativas. Muitas vezes o início ou término de uma situação durativa (processo ou estado) é expresso lexicalmente por outro verbo, tais como os listados em (236) (cf. o que dissemos a este respeito no item 3.2). 
236. a - Verbos que indicaram início de um processo: partir (início de ir ou vir) nascer (início de viver)

b- Verbos que indicam início de um estado, normalmente chamados de incoativos: ${ }^{22}$ adoecer (início de estar doente) engordar (início de estar gordo) endurecer (início de estar duro) ${ }^{23}$

c - Verbos que indicam término de um processo: chegar (término de ir ou vir) morrer (término de viver) vencer (término de disputar, lutar) achar (término de procurar) decidir (término de pensar o que fazer)

Quando temos frases com estes verbos, tais como os exemplos (104) e (116) - com verbos do tipo dos de (236a); (64 a 68) e (105) - com verbos do tipo dos de (236b) e (71), (99), (107), (108), (110), (115) - com verbos do tipo dos de (236c), não podemos dizer que aí temos aspectos inceptivo ou terminativo pela simples presença destes verbos. Isto porque a incepção ou a terminação dos processos e estados não estão marcadas gramaticalmente, uma vez que estes não estão sendo apresentados no seu início ou término, pois o que fazemos é falar de uma situação cuja realização implica o início ou término deles e não deles em si. Embora logicamente saibamos que tais verbos expressam situações que representam o início ou o término de outras, não podemos dizer que os aspectos em questão foram atualizados, assim como não podemos falar em aspecto durativo ou pontual por termos processos ou eventos na frase e não podemos falar em aspecto iterativo, porque a frase tem um verbo do tipo de saltitar (cf. 4.2.6 - aspecto iterativo).

\subsubsection{5 - NÃO ASPECTO}

Como vimos no item 2.2.2, pode acontecer que nenhuma noção aspectual esteja presente na frase. Neste caso, não haverá referência à duração ou às fases da situação, pois a categoria de aspecto não terá sido atualizada. Na segunda parte,

\footnotetext{
${ }^{22}$ Muitos autores vinculam os verbos incoativos ao aspecto inceptivo, pois, se eles indicam mudança de estado, implicam no início de um novo estado (cf. item 2.3.3).

${ }^{23} \mathrm{Nem}$ todos os verbos incoativos são eventos. Na verdade, a maioria deles parece ser processo. De qualquer forma são situações inceptivas
} 
veremos alguns casos em que normalmente isto ocorre. As frases (61) a (63) e as frases (237) a (241) abaixo são exemplos nos quais o aspecto não foi atualizado.

237. Você tem de prestar atenção.

238. Hei de passar no concurso.

239. As crianças precisam se alimentar bem.

240. Posso servir o jantar?

241. Se ele pagar a taxa até amanhã, não haverá problema.

\section{3 - A ATUALIZAÇÃO DO ASPECTO}

Pelo quadro III vemos que existem quatro grupos de distinções aspectuais: um ligado à duração e três ligados às fases. Além da ausência total de atualização do aspecto, podemos ter a não atualização de um ou outro grupo de distinções em dada frase. Isto significa que uma forma verbal não precisa estar marcada para os quatro tipos de distinções aspectuais, mas pode estar marcada apenas para uma, duas, ou três destas distinções. Assim, por exemplo, uma forma verbal pode estar marcada apenas para a distinção perfectivo/imperfectivo sem estar marcada para as outras três distinções e assim por diante. Portanto, ao proceder à análise aspectual de uma frase, não se tem, obrigatoriamente, que dizer aspectos referentes às quatro distinções aspectuais, mas apenas aspectos referentes às distinções para as quais a situação expressa está marcada. Abaixo damos alguns exemplos de análise em que se pode observar o que acabamos de dizer.

242. João foi esquecendo aquela cena horrível. (perfectivo, durativo).

243. As roseiras que podei começam a brotar. (imperfectivo, inceptivo, começado).

244. Joana está pintando um quadro para mim. (imperfectivo, durativo, não acabado, cursivo).

245. Rafael começará a trabalhar amanhã. (inceptivo).

246. Acabamos de receber um telegrama de João. (acabado, pontual).

247. Eu corro $3 \mathrm{~km}$ todos os dias de manhã. (imperfectivo, habitual, não acabado).

248. César já pintou muito hoje. (perfectivo). 
O aspecto verbal no Português: a categoria e sua expressão 


\section{5 - Relações entre os aspectos}

Os aspectos mantêm entre si certas tendências de relacionamento. Foram essas tendências, tomadas como absolutas, que levaram alguns estudiosos a caracterizarem aspectos compostos, pois, tendo em vista o frequente aparecimento conjunto de duas noções aspectuais, concluiu-se que estas estavam sempre juntas e caracterizavam um só aspecto. Foi o que aconteceu, por exemplo, com o completamento e o acabamento em relação ao perfectivo.

\section{1 - ReLAÇÕES ENTRE ASPECTOS DO MESMO GRUPO DE DISTINÇõeS ASPECTUAIS}

Antes de mais nada é preciso dizer que os aspectos pertencentes a um mesmo grupo de distinções são mutuamente exclusivos. Não podemos ter, por exemplo, uma situação apresentada ao mesmo tempo como durativa e iterativa, ou iterativa e indeterminada, ou começada e não começada, ou inceptiva e cursiva, ou perfectiva e imperfectiva. Se tivermos dois aspectos do mesmo grupo marcados para uma mesma forma, certamente não se referirão à mesma situação. Nestes casos, normalmente, um aspecto se referirá à situação narrada e o outro à referencial ou então um se referirá à situação criada pela repetição e o outro à situação que se repete. Vejamos a este respeito os exemplos (249) e (250) abaixo.

249. O Sr. Manuel tem ficado a vigiar a casa para mim. Aqui temos os aspectos imperfectivo, cursivo, não acabado, iterativo para a situação criada pela repetição e o aspecto durativo para a situação de "ficar vigiando" que se repete. Quando falamos de aspecto habitual mostramos a ocorrência deste fato (cf. 4.2.7 - exemplos: 210 a 214).

250. A tábua está lixada.

Aqui temos os aspectos imperfectivo, não acabado, cursivo e durativo para a situação referencial, que é o estado de "estar lixado", e temos o aspecto acabado para a situação narrada de "lixar". 
Estes fatos nos mostram que ao fazermos uma análise aspectual, se encontrarmos dois aspectos pertencentes ao mesmo grupo marcados para uma mesma forma, certamente eles se referem a situações distintas, mas nunca à mesma.

\section{2 - RELAÇÕES ENTRE ASPECTOS DE DIFERENTES GRUPOS DE DISTINÇÕES ASPECTUAIS}

Vejamos agora as relações entre os aspectos pertencentes a grupos diferentes de distinções. Vamos começar pelas relações entre o perfectivo e o imperfectivo e os demais aspectos pela mesma razão que nos levou a falar sobre os dois em primeiro lugar.

\subsection{1 - IMPERFECTIVO E INCEPTIVO, CURSIVO E TERMINATIVO}

O imperfectivo pode aparecer ao lado do inceptivo, cursivo e terminativo para a mesma situação, já que apresenta a situação como incompleta, e estes três aspectos apresentam a situação em uma de suas fases de desenvolvimento, portanto como incompleta. Veja os exemplos (251) a (253).

251. Flávio estava começando a pintar (ou começava a pintar) um quadro quando cheguei à casa dele.

a) S.R.: começar a pintar - imperfectivo, não acabado, cursivo,durativo.

b) S.N.: pintar - imperfectivo, inceptivo, começado.

252. Flávio está pintando um quadro há 2 horas. (imperfectivo, cursivo, não acabado, durativo).

253. Flávio está terminando de pintar (ou termina de pintar) um quadro para mim.

a) S.R.: terminar de pintar - imperfectivo, não acabado, cursivo,-durativo.

b) S.N.: pintar - imperfectivo, terminativo, não acabado.

O inceptivo, o cursivo e o terminativo podem aparecer ao lado do imperfectivo também para situações diferentes (cf. exemplos: 210, 211 e 214).

\subsection{2 - Perfectivo e inceptivo, CURSivo e terminativo}

O perfectivo, por apresentar a situação como completa, nunca aparece ao lado do inceptivo, cursivo e terminativo para a mesma situação, já que estes a 
apresentam em uma de suas fases de desenvolvimento, ou seja, como incompleta. Para situações diferentes o perfectivo aparece com o inceptivo e o terminativo (exemplos 254 e 255) mas não aparece com o cursivo.

254. Comecei a pintar a casa às 7 horas.

a) S.R.: "comecei a pintar" - perfectivo, acabado, pontual.

b) S.N.: "pintar" - inceptivo, começado.

255. Terminei de guardar os tijolos quando anoitecia.

a) S.R.: "Terminei de guardar" - perfectivo, acabado, pontual.

b) S.N.: "guardar" - acabado, terminativo.

Poder-se-ia pensar que em frases do tipo de (256) e (257) tivéssemos o perfectivo ao lado do inceptivo e do terminativo para a mesma situação.

256. César esteve começando a pintar a grade, mas desistiu.

257. César esteve terminando de lixar a parede, mas saiu.

Todavia parece-nos que em (256) e (257) não temos a junção daqueles aspectos, mas sim duas formas verbais independentes: a primeira, o verbo "estar", com aspectos perfectivo e acabado, indicando que alguém esteve em algum lugar; a segunda, as perífrases "começar + a + infinitivo" e "terminar + de + infinitivo" (cf. capítulo 8), sem aspecto atualizado, indicando o que esse alguém fez no referido lugar. Outra forma de ver tais frases, e talvez preferível à já apresentada, é vê-las como indicadoras de que alguém não chegou a passar dos primeiros momentos de uma situação (exemplo 256) ou não chegou ao seu ponto de término (exemplo 257), sem contudo apresentar tal situação em seu momento de início ou em seus primeiros momentos; ou em seu ponto de término ou em seus últimos momentos.

\subsection{3 - IMPERFECTIVO E NÃO COMEÇADO, COMEÇADO E ACABADO}

Para a mesma situação o imperfectivo normalmente aparece ligado ao não acabado, exemplos (8a, b), (11 a-c), (22), (38), (39), (44), (45), (49 a 51), (53), (65), (67), (114 a 117), (126), (250 a 253). Com o acabado pode aparecer para a mesma situação em frases como (154) e (258), ou como (155) e (156) nas quais temos verbos de estado ou atélicos no pretérito imperfeito do indicativo e ênfase entonacional do verbo na fala (ver o que dissemos a este respeito em 4.1.).

258. Meu irmão sempre comprava doces para mim. (imperfectivo, acabado, habitual). 
O acabado aparece ao lado do imperfectivo também para situações diferentes em frases como (72 a 75), (128), (130) e (250).

72. Tenho a lição estudada.

a) S.R.: "ter a lição estudada" (um estado) - imperfectivo, não acabado, cursivo, durativo.

b) S.N.: "estudar" - acabado.

128. O vaso está quebrado.

a) S.R.: estado de "estar quebrado"- imperfectivo, não acabado, cursivo, durativo.

b) S.N.: "quebrar" - acabado. ${ }^{1}$

O imperfectivo não aparece ao lado do não começado para a mesma situação, mas para situações diferentes aparece em frases como (34), (132) e (259).

259. O carro está por consertar até hoje.

a) S.R.: estado de "estar por consertar"- imperfectivo, não acabado, cursivo, durativo.

b) S.N.: "consertar"- não começado.

\subsection{4 - PERfeCtivo E NÃO COMEÇADO, COMEÇADO E ACABADO}

O perfectivo só aparece ao lado do não começado para situações diferentes, como nos exemplos (37) e (260).

260. Esta calça esteve por costurar durante a semana toda.

a) S.R.: "esteve por costurar"- perfectivo, acabado, durativo.

b) S.N.: "costurar" - não começado.

O perfectivo pode aparecer ao lado do não acabado para a mesma situação em frases como (153) e (261) abaixo. Veja-se também os comentários feitos para o exemplo (834) no item 8.3.3.

261. Maria sempre comprou muita verdura na feira (perfectivo, não acabado, habitual).

\footnotetext{
${ }^{1}$ Foi o acabado da situação narrada que levou Castilho (1967) a dizer que, em tais frases, tínhamos aspecto perfectivo para o estado expresso. Castilho não distinguiu situações narradas de situações referenciais.
} 
O perfectivo aparece ao lado do não acabado para situações diferentes em frases como (131) e (262).

262. José continuou falando apesar do barulho.

a) S.R.: "continuar falando" - perfectivo, acabado, pontual.

b) S.N.: "falar" - não acabado ou começado, durativo.

Para a mesma situação o perfectivo aparece normalmente ligado ao acabado como nos exemplos (41), (42), (46), (58), (59), (79), (99), (109), (141), (143) entre outros. Abaixo transcrevemos dois destes exemplos.

41. Pedro pulara o muro com facilidade.

58. A menina esteve balançando por muito tempo lá fora.

Observa-se que praticamente todas as situações que são apresentadas com aspecto acabado têm também aspecto perfectivo; a única exceção parecem ser frases do tipo de (154) e (258) e as do tipo de (155) e (156).

\subsection{5 - IMPERFECTIVO/ PERFECTIVO E OS ASPECTOS CARACTERIZADOS PELA DURAÇÃO E PONTUALIDADE}

O imperfectivo, por apresentar a situação como incompleta, aparece mais naturalmente ao lado de aspectos durativos. Também estes são mais naturais com o imperfectivo, daí serem mais frequentes ao lado deste aspecto que ao lado do perfectivo.

É muito comum que uma situação que tenha aspecto imperfectivo tenha também aspecto durativo. Podemos observar isto em exemplos como (8a, b), (11a, b), (38), (39), (49), (50), (55), (65), (67), (68), (70), (72 a 75), (95), (114 a 117), (120a), (126), (128), (132). Transcrevemos abaixo quatro destes exemplos.

11b. Estamos fazendo um bolo para mamãe.

65. A valente tropa fraquejava.

70. Chega o inverno, aos poucos as árvores ficam esqueléticas.

126. José está doente.

$\mathrm{O}$ aspecto perfectivo, por apresentar a situação como completa, parece ser mais natural com a pontualidade e vários autores anotam esta tendência. ${ }^{2}$ Embora isto seja

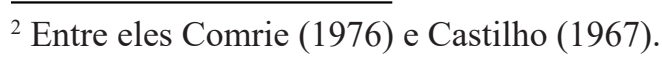


verdade, a realidade maior é que as formas perfectivas antes fazem abstração da duração do que apresentam a situação como pontual. Na verdade não é raro termos o perfectivo e o durativo para uma mesma situação como se pode constatar nos exemplos (10), (42), (58), (60), (69), (71), (82), (122a), (139), (140), (143), (144), (146) e (263 a 265).

58. A menina esteve balançando lá fora por muito tempo.

60. Maria ficou olhando as fotos durante várias horas.

69. O amor dos tios foi transformando aquela criança.

263. Este armário esteve sujo muito tempo.

264. Ele veio falando sobre esta injustiça até que alguém o ouviu.

265. Procurei, procurei, mas não encontrei meu livro.

O perfectivo aparece com o durativo também para situações diferentes, como na frase (262).

As frases com aspecto indeterminado quase sempre têm aspecto imperfectivo. Encontramos poucos exemplos em que a situação tem ao mesmo tempo aspecto indeterminado e perfectivo. Isto ocorre em frases com a perífrase "ser + de + infinitivo" no pretérito perfeito do indicativo (exemplo 266) e no maisque-perfeito, e de modo geral em frases com o verbo ser no pretérito perfeito do indicativo (exemplos 267 e 268). Não se incluem aqui as frases de voz passiva e do verbo ser + particípio variável de verbo intransitivo (cf. item 8.15.2). O pouco aparecimento de perfectivo e indeterminado juntos talvez se explique pelo fato de que uma situação que dure sempre, muito raramente será vista como completa na concepção dos falantes. Vejam-se os exemplos (12 a 19), (171) e (172 a 182), em que temos imperfectivo e indeterminado. Uma evidência de que o imperfectivo e o indeterminado estão fortemente relacionados é o fato de este último, no passado, ser sempre expresso pelo pretérito imperfeito do indicativo que é um tempo que sempre marca o aspecto imperfectivo. Veja exemplos (18), (19), (269) e (270).

266. Sérgio já foi de dançar a noite toda. ${ }^{3}$

267. Alex foi professor.

268. Celina foi feliz até conhecer você.

269. Os jogadores do Brasil eram de estatura média.

270. Outrora as pessoas se preocupavam mais umas com as outras.

\footnotetext{
${ }^{3}$ Com a perífrase SER + DE + INFINITIVO no pretérito perfeito do indicativo e no pretérito maisque-perfeito do indicativo temos sempre a combinação de perfectivo e indeterminado.
} 
As frases com aspecto iterativo são mais comuns com o aspecto imperfectivo para a mesma situação. Exemplos de situações marcadas para os aspectos imperfectivo e iterativo são encontrados nas frases de número (11c), (21 a 24), (30b), (118a, b), (119a), (121), (159), (188) e (194 a 196), três das quais transcrevemos abaixo.

24. Tenho pulado corda para emagrecer.

159. Célia anda limpando a casa para mim.

188. As crianças ora choravam, ora brincavam.

Podemos ter também o iterativo ao lado do perfectivo para a mesma situação. É o que temos nos exemplos (57), (160), (186), (187) e (271).

57. Célia andou indo ao cinema com Élio.

271. Marco veio várias vezes aqui, mas não disse nada.

O aspecto habitual também aparece mais comumente combinado ao aspecto imperfectivo para a mesma situação, embora não seja impossível termos perfectivo e habitual para a mesma situação.

São exemplos em que temos imperfectivo e habitual para a mesma situação as frases de números (20), (25 a 29), (30a), (154), (197 a 203) e (258), três das quais transcrevemos abaixo.

20. D. Maria passeia todos os dias na praia.

29. Todas as noites escovava os dentes com cuidado.

202. Embora Valdete viva caminhando pelo bosque, não conhece todos os seus recantos.

Embora encontremos exemplos nos quais temos os aspectos habitual e perfectivo para a mesma situação, os exemplos em que isso ocorre não são muito comuns pela mesma razão que é raro termos uma situação com aspectos indeterminado e perfectivo: é difícil conceber uma situação de duração ilimitada como completa, uma vez que a situação completa implica que os limites da duração sejam estabelecíveis ou perceptíveis. As frases do tipo dos exemplos (153), (261), (272) e (273) e as frases com perífrases "usar + infinitivo" no pretérito perfeito do indicativo (ver 8.6.5), são o único tipo de frase em que encontramos os aspectos perfectivo e habitual para a mesma situação. 
272. Ele sempre falou comigo.

273. Meu filho sempre lavou o quintal para mim.

Já dissemos no capítulo 4, ao falar do aspecto pontual, que toda situação que é apresentada com aspecto pontual tem também aspecto perfectivo. Assim sendo, não temos nenhum caso em que o imperfectivo e o pontual apareçam juntos. Isto pode ser visto nos exemplos (215) a (222) e (274) a (280).

274. "Tomo o carro, parto para as férias". (V. Ferreira)

275. "Descobre, com amargura, que de agora em diante ja mais será completo para com ela". (C.H. Cony)

276. "Até emudecer, totalmente, quando a luz se apaga". (C.H. Cony)

277. "Azevedo Gondim apagou o sorriso, engoliu em seco, apanhou os cacos de sua vaidade e replicou amuado que um artista não pode escrever como fala". (G. Ramos)

278. "A galinha tombou num baque surdo e lá ficou”. (V. Ferreira)

279. “Cruzou-me o espírito a visão do Niágara”. (Paço D’Árcos) ${ }^{4}$

280. Marcelo surgiu inesperadamente, deixando todos encabulados.

\subsection{6 - ACABADO E INCEPTIVO, CURSIVO E TERMINATIVO}

Não encontramos exemplos em que o acabado e o inceptivo aparecessem juntos para a mesma situação, todavia eles aparecem juntos para situações diferentes. É o que acontece, por exemplo, em frases como (254) e (281).

281. Às oito horas o público começou a se aglomerar na porta do teatro.

a) S.R.: "começou a se aglomerar" - perfectivo, acabado,pontual.

b) S.N.: "aglomerar-se" - inceptivo, começado.

Também o cursivo só aparece junto ao acabado para situações diferentes, como era de se esperar. Veja os exemplos (250) e (282).

\footnotetext{
${ }^{4}$ Exemplos (274) a (276) apud Castilho (1967, p.81). Exemplos (277) a (279) apud Castilho (1967, p.82). No exemplo (277) Castilho dá como pontual também a situação de "apanhou os cacos". Para nós, neste caso, há antes abstração da oposição durativo/pontual do que pontualidade, já que podemos usar adjuntos adverbiais tanto de duração quanto pontuais.
} 
282. O pão está cortado.

a) S.R.: estado de "estar cortado" - imperfectivo, cursivo, não acabado, durativo.

b) S.N.: "cortar" - acabado

O terminativo aparece ao lado do acabado para a mesma situação. Veja os exemplos (255) e (283).

283. Os alunos terminaram de fazer a prova às 3 horas.

a) S.R.: "terminaram de fazer" - perfectivo, acabado, pontual.

b) S.N.: "fazer a prova" - acabado, terminativo.

\subsection{7 - COMEÇADO E INCEPTIVO, CURSIVO E TERMINATIVO}

O começado ou não acabado aparece junto ao inceptivo (exemplos: 44, 45, 47, 106, 161 - 2 $2^{\mathrm{a}}$ locução, 162 e 251), ao cursivo (exemplos: 8a, b; 11a, b; 34; $39 ; 49 ; 50 ; 55 ; 65 ; 67 ; 72 ; 117 ; 120$ a; $126 ; 128 ; 164 ; 165 ; 191$ a $193 ; 230$ a 232 e 252) e ao terminativo (exemplos 51, 53, 54, 163 e 253), para a mesma situação, como se pode ver pelos exemplos citados. Esse é o relacionamento mais comum entre os aspectos das fases de desenvolvimento e os das fases de realização já que, como vimos, as primeiras são subdivisões da fase de realização em que a situação é começada ou não acabada. O começado ou não acabado pode aparecer junto ao inceptivo (exemplo 251), ao cursivo (exemplo 210) e ao terminativo (exemplo 253), também para situações diferentes.

\subsection{8 - NãO COMEÇADO E INCEPTIVO, CURSIVO E TERMINATIVO}

O não começado nunca aparece junto ao inceptivo e ao terminativo nem para a mesma situação nem para situações diferentes. Já o cursivo aparece ao lado do não começado só para situações diferentes em frases como (34), (132) e (259), por exemplo.

\subsection{9 - PONTUAL E INCEPTIVO, CURSIVO E TERMINATIVO}

O cursivo não aparece junto do pontual nem para a mesma situação, nem para situações diferentes. Isto se explica porque, como vimos, todo pontual é perfectivo e este não aparece com o cursivo nem para a mesma situação nem para situações diferentes, como já foi explicado no item 5.2.2. 
O inceptivo pode aparecer ao lado do pontual para situações diferentes em frases como (254) e (281).

O terminativo aparece ao lado do pontual para situações diferentes em frases como (255) e (283).

Quando temos o inceptivo e o terminativo ao lado do pontual para situações diferentes, a situação que é pontual tem também aspecto perfectivo como era de se esperar, já que todo pontual é também perfectivo. Quando temos uma situação com aspecto imperfectivo ao lado do inceptivo ou terminativo para a mesma situação como nas frases (251) e (253) respectivamente, poder-se-ia pensar que essas situações têm também aspecto pontual, já que só podemos utilizar nestas frases adjuntos adverbiais do tipo de "agora", "neste instante", "às 3 horas", "quando cheguei à casa dele" (elemento adverbial em 251), ou seja, adjuntos adverbiais de tempo pontuais. Se assim fosse, teríamos um contra exemplo à colocação de que toda situação com aspecto pontual tem também aspecto perfectivo uma vez que não se pode questionar que em (251) e (253) haja aspecto imperfectivo. Também teríamos aspecto inceptivo e terminativo junto com o pontual para a mesma situação. Entretanto pode-se demonstrar que não temos aí uma tal contra exemplo, porque, na verdade, frases como (251) e (253) não são marcadas para a oposição durativo/pontual.

Em primeiro lugar, observe-se que os elementos adverbiais pontuais (adjuntos ou orações), que podem ser utilizados nas frases em questão indicam nelas não o momento de ocorrência da situação, como acontece em frases com aspecto pontual (ver exemplo 284). Indicam, antes, um dos momentos em que a situação estava ocorrendo, estava em andamento ou que a situação está ocorrendo, está em andamento no momento em que se fala, como em frases do tipo de (285). Portanto não valem como evidência de que temos aspecto pontual ou não marcação da oposição durativo/pontual.

284. Neste instante cruza-me o espírito a visão do Niágara. (A situação se dá num único instante).

285. Neste instante os operários estão carregando o caminhão. (Isto é, no momento em que se fala a ação de carregar está ocorrendo, mas ela estava ocorrendo antes do momento da fala e continuará ocorrendo após o momento da fala).

Em segundo lugar, em frases como (285), podemos colocar um adjunto adverbial durativo (cf. exemplo 285a) porque aí temos aspecto durativo marcado pela perífrase "estar + gerúndio" (cf. item 8.3.2). 


\section{5a. Os operários estão carregando o caminhão há duas horas.}

Frases como (251) e (253) são do mesmo tipo de (285) e portanto, com aspecto durativo marcado pela perífrase "estar + gerúndio". Assim sendo, não constituem contra exemplo ao fato de que todo pontual é perfectivo. Entretanto permanece ainda uma questão: se têm aspecto durativo, por que frases do tipo de (251) e (253) não podem ser usadas com adjunto adverbial de duração? Respondemos a isto no parágrafo seguinte.

A impossibilidade de utilização de adjuntos adverbiais de duração em tais frases se explica não pela presença de aspecto pontual, mas por outras razões semânticas. Em frases do tipo de (251), com aspecto inceptivo, apresentando a situação em seus primeiros momentos, normalmente fica estranho apresentar a duração de uma situação, que ocorre a poucos instantes, quer se trate da situação narrada "estudar", quer se trate da situação referencial "começar a estudar" (cf. exemplo 286) e o falante não aceita a frase.

286. ? * Flávio está começando a estudar há 3 segundos.

Em frases do tipo de (253), com aspecto terminativo, apresentando a situação narrada em seus últimos momentos, não haveria o problema de estranheza por apresentar a duração da situação, mas uma frase como (287) também não é aceita pelo falante.

287. ?* Flávio está terminando de estudar há uma hora.

Se em (287) não há problema de apresentar a duração de situação, já que ela começou há muito tempo, por que a frase não é aceita? O que ocorre aqui é que a duração expressa no adjunto adverbial é interpretada não como duração da situação narrada “estudar", mas da situação referencial "terminar de estudar", daí a estranheza da frase e sua não aceitação, pois normalmente não se concebe que alguém esteja terminando algo há tanto tempo. ${ }^{5} \mathrm{~A}$ colocação de uma duração pequena como "há 3 segundos" não torna a frase aceitável, pela mesma razão exposta quando falávamos da situação inceptiva antes do exemplo (286).

\footnotetext{
${ }^{5}$ Uma frase como (287) e uma frase como (286), mas com uma duração maior para a situação referencial de "começar a estudar" como na frase abaixo:

Flávio está começando a estudar há mais de duas horas.

Só são aceitas em contextos especiais, ditas com entonação adequada para expressar que a pessoa fica dizendo estar começando ou terminando algo, mas em realidade não começa, nem termina. O adjunto adverbial durativo indica o tempo que a pessoa está dizendo começar ou terminar a situação sem contudo fazê-lo.
} 


\subsubsection{0 - HABITUAL E INCEPTIVO, CURSIVO E TERMINATIVO}

O inceptivo, o cursivo e o terminativo podem aparecer ao lado do habitual para situações diferentes. Nestes casos, a situação criada pela repetição normalmente tem aspectos imperfectivo e habitual e a situação que se repete é que é apresentada como inceptiva, cursiva ou terminativa. (Cf. o que comentamos a este respeito no item 4.2.7, quando falamos do aspecto habitual). As frases (210), (211) e (214) são exemplos do que acabamos de dizer.

210. Todo dia, quando chego, Verinha está batendo a máquina. (imperfectivo, habitual, não acabado). - situação que se repete - imperfectivo, cursivo.

211. Ele começa a treinar sempre às 6 da manhã. (imperfectivo, habitual, não acabado).

- situação que se repete - imperfectivo, inceptivo.

214. Sempre que chego em casa, meu filho está terminando de fazer os deveres. (imperfectivo, habitual, não acabado). - situação que se repete - imperfectivo, terminativo.

O inceptivo e o terminativo não aparecem juntos ao habitual para a mesma situação. Já o cursivo aparece junto ao habitual para a mesma situação em todas as frases em que se tem também o aspecto imperfectivo. Em outras palavras, sempre que temos o aspecto habitual temos também o aspecto cursivo, exceto quando o perfectivo aparece com o habitual em frases do tipo de (153), (261), (272) e (273). Exemplos de habitual e cursivo juntos para a mesma situação são frases como (197) a (207). O fato de o habitual se caracterizar por uma duração descontínua ilimitada enfraquece grandemente a ideia de cursividade presente em tais frases, levando quase sempre a não considerar sua presença e a considerá-la como não marcada.

\subsubsection{1 - ITERATIVO E INCEPTIVO, CURSIVO E TERMINATIVO}

O inceptivo e o terminativo não aparecem ao lado do iterativo nem para a mesma situação nem para situações diferentes.

Toda vez que temos os aspectos iterativo e imperfectivo para uma situação temos também o cursivo. Isto se pode ver nos exemplos (11c), (21 a 24), (30b), (118a, b), (119a), (121) e (159) dois dos quais transcrevemos abaixo. 
117. Minha cabeça tem doído muito.

159. Célia anda limpando a casa para mim.

Se tivermos iterativo e perfectivo como em (57) não teremos cursivo já que este aspecto e o perfectivo nunca aparecem juntos. $\mathrm{O}$ mesmo que dissemos para o cursivo em relação ao habitual vale, "mutatis mutandis", para o iterativo.

\subsubsection{2 - INDETERMINADO E INCEPTIVO, CURSIVO E TERMINATIVO}

O inceptivo e o terminativo não aparecem ao lado do indeterminado, nem para a mesma situação nem para situações diferentes.

Sempre que temos os aspectos indeterminado e imperfectivo para uma situação, temos também o cursivo. Isto se pode ver nos exemplos (12 a 19) e (172 a 182), dois dos quais transcrevemos abaixo:

12. A Terra gira em torno do sol.

179. João é um rapaz inteligente.

Se tivermos indeterminado e perfectivo, como no exemplo (266), não teremos cursivo já que este aspecto e o perfectivo nunca aparecem juntos.

O fato da situação apresentada pelo aspecto indeterminado ter uma duração contínua ilimitada enfraquece grandemente a ideia de cursividade presente em tais frases. Isto leva, quase sempre, a não considerar sua presença, tomando-a como não marcada.

\subsubsection{3 - DURATIVO E INCEPTIVO, CURSIVO E TERMINATIVO}

O inceptivo e o terminativo não aparecem com o durativo para a mesma situação. Para situações diferentes aqueles aparecem junto deste em frases como (251) e (253).

É comum termos aspecto cursivo para uma situação que também tem aspecto durativo. Isto pode ser observado nos exemplos (8b), (9b), (11a), (38), (49), (55), (65), (68), (70), (72 a 75), (120a), (126) e (132), alguns dos quais transcrevemos abaixo, e também o exemplo (288) abaixo.

8b. Sílvia limpava a casa desde cedo e ainda não acabara, quando voltamos.

65. A valente tropa fraquejava.

70. Chega o inverno, aos poucos as árvores ficam esqueléticas. 
120a. Tenho amado você e mais ninguém.

288. Adriana está feliz.

Como o perfectivo e o cursivo nunca aparecem juntos, em todas as frases em que temos aspecto durativo e perfectivo não temos aspectos cursivo.

\subsubsection{4 - PontuAl E ACABADO, COMEÇADO E NÃO COMEÇADO}

O acabado aparece junto ao pontual para a mesma situação em frases como (133 a 135), (151), (221), (222), (254), (255), (262), (277 a 279), (281) e (283), algumas das quais transcrevemos abaixo.

134. "Principiou a falar pausadamente depois agitou-se, parecia um louco".(F. Namora)

a - S.R.: "principiou a falar" - perfectivo, pontual, acabado.

b - S.N.: "falar" - começado.

222. Achei seu anel dentro da gaveta do criado. (Perfectivo, pontual, acabado).

225. Terminei de guardar os tijolos quando anoitecia.

262. José continuou falando apesar do barulho.

Em frases como (255) o acabado aparece junto ao pontual também para situações diferentes.

O pontual e o não começado nunca aparecem juntos nem para a mesma situação nem para situações diferentes.

O pontual não pode aparecer com o não acabado ou começado para a mesma situação, mas estes dois aspectos aparecem juntos para situações diferentes em frases como (254) e (262). Em frases como (289) abaixo também se pode dizer que temos o pontual e o não acabado juntos para situações diferentes já que a situação criada pela repetição tem aspectos perfectivo, habitual e não acabado e cada realização da situação que se repete é vista como tendo aspectos perfectivo e pontual.

289. João sempre achou coisas na rua.

\subsubsection{5 - HABITUAL E ACABADO, COMEÇADO E NÃO COMEÇADO}

O habitual nunca aparece junto com o não começado para a mesma situação. Para situação diferentes, estes dois aspectos podem aparecer juntos em frases como (290). 
290. Sempre que há inspeção, tudo neste escritório está por arrumar. a) situação criada pela repetição - imperfectivo, habitual, não acabado.

b) cada realização da situação narrada que se repete - não começado.

Normalmente quando uma situação é apresentada com aspecto habitual ela tem também aspecto começado ou não acabado, como se pode ver nos exemplos (20), (25 a 28), (30a), (153), (199), (200), (202 a 207), dois dos quais transcrevemos abaixo.

$20 . \quad$ D. Maria passeia todos os dias na praia.

202. Embora Valdete viva caminhando pelo bosque, não conhece todos os seus recantos.

O habitual passado com o pretérito imperfeito do indicativo, que se vê em frases como (29), (154), (197), (198), (201) e (291a) abaixo, parece implicar que a situação não mais se mantém, tendo, portanto, aspecto acabado. ${ }^{6}$

291. a - Ricardo costumava ir ao clube.

Entretanto, observamos que não se trata de uma implicação no sentido estrito, porque aceita elementos que um acabado estritamente marcado não aceitaria (ver exemplos 291 b-d).

291. b - Ricardo costumava ir ao clube e ainda vai.

c - Ricardo costumava ir ao clube, mas não sei se ainda vai ou não vai mais.

d - Ricardo costumava ir ao clube, mas não vai mais.

Se em (291a) houvesse uma implicação estrita de acabado, (291b) seria inaceitável, porque haveria uma contradição, (291c) também seria inaceitável, pois não haveria as duas possibilidades e (291d) seria estranha por ser redundante. Dessa forma, a implicação de acabado só valerá se não houver nada que a suspenda.

\footnotetext{
${ }^{6}$ Comrie (1976, p.28) observou o mesmo fato para o inglês e o russo e verificou que, também nestas línguas, não há uma implicação estrita e disse então haver uma implicatura, termo com que denominaria uma implicação mais fraca
} 
Observe nos exemplos abaixo que, quando o acabado é realmente marcado, elementos do tipo dos acrescidos a (291a) em (291b-d) tornam as frases estranhas e inaceitáveis.

292. a - Ricardo tinha lavado o carro, quando chegamos. (acabado) $\mathrm{b}$ - * Ricardo tinha lavado o carro, quando chegamos, mas ainda estava lavando o carro.

c - * Ricardo tinha lavado o carro, mas não sei se lavou ou não lavou o carro.

d - ? Ricardo tinha lavado o carro, mas lavou o carro.

Frases como (292b-d) acima só serão aceitas em contextos especiais.

O mesmo tipo de raciocínio acima vale para frases com aspecto habitual com a perífrase "usar + infinitivo" no pretérito perfeito do indicativo (ver item 8.6.5, exemplo 995), e também com a perífrase "costumar + infinitivo" (ver item 8.6.4), mas as frases com estas perífrases são pouco usadas.

O habitual aparece ao lado do acabado em sentido estrito em frases como (293) e (294).

293. Antônio não fuma mais. (imperfectivo, acabado, habitual)

294. Desde aquele dia, Celina não esquece mais de dar os recados. (imperfectivo, acabado, habitual)

Acabado e habitual aparecem juntos para situações diferentes em frases como (296) (ver no item 5.2.17) e (1264), (1265) (ver no item 8.15.3).

\subsubsection{6 - ITERATIVO E ACABADO, COMEÇADO E NÃO COMEÇADO}

O iterativo e o não começado não aparecem juntos para a mesma situação. Para situações diferentes parece que estes dois aspectos aparecem lado a lado em frases como (295) abaixo.

295. João esteve para vir várias vezes.

a) situação criada pela repetição - perfectivo, iterativo.

b) situação narrada que se repete - não começado.

Para a mesma situação, normalmente o iterativo aparece junto ao não acabado ou começado como se pode ver pelas frases de números (11c), (21 a 24), (30b), (118a,b) (119a), (121a), (153), (159), algumas das quais transcrevemos abaixo. 
23. De tempos em tempos explodia uma bomba.

118b. Tenho engolido muito desaforo.

159. Célia anda limpando a casa para mim.

O acabado e o iterativo não aparecem juntos para situações diferentes. Para a mesma situação o acabado e o iterativo aparecem juntos em frases como (809) a (812) (cf. item 8.3.2) mas este tipo de frase é muito pouco frequente. Abaixo antecipamos o exemplo (809a), para facilidade do leitor.

809. a - Os trens estiveram partindo pela manhã. (perfectivo, acabado, iterativo)

Em muitas frases em que temos iterativo e perfectivo; como nos exemplos (57), (160), (186), (187) e (271); poder-se-ia pensar que temos também aspecto acabado, mas isso não ocorre porque, na verdade, em tais frases as situações não são marcadas para a oposição acabado/não acabado.

\subsubsection{7 - INDETERMINADO E ACABADO, COMEÇADO E NÃO COMEÇADO}

O indeterminado e o não começado não aparecem juntos nem para a mesma situação nem para situações diferentes.

Normalmente quando uma situação é apresentada com aspecto indeterminado ela tem também aspecto começado ou não acabado, como se pode ver nos exemplos (12 a 17), (171), (172 a 182), dois dos quais transcrevemos abaixo.

14. Este cachorro morde.

178. Esta obra apresenta o homem feliz.

$\mathrm{O}$ indeterminado e o acabado aparecem juntos para a mesma situação em frases como (266) a (268) e (296) a (298) abaixo.

296. Carlos foi de viajar muito, mas depois o dinheiro acabou e ele teve de se aquietar. (indeterminado, perfectivo, acabado).

297. Não somos mais escravos. (imperfectivo, acabado, indeterminado).

298. Valéria não é mais sadia. (imperfectivo, acabado, indeterminado).

Em frases como (18), (19), (269) e (270), nas quais temos o indeterminado passado com o pretérito imperfeito do indicativo, temos a implicação não estrita de 
acabado; em outras palavras, temos um aspecto acabado apenas aparente, que não é na realidade marcado. Ocorre aqui o mesmo fato registrado quando comentamos a relação do acabado e do habitual. Aqui como lá podemos provar que o acabado não é marcado, acrescentando à frase elementos semelhantes aos acrescentados a (291a) e que tornariam a frase inaceitável se o acabado fosse marcado. Veja (19) e (299 a-c) abaixo.

19. O clube ficava no topo da colina.

299. a - O clube ficava no topo da colina e ainda fica.

b - O clube ficava no topo da colina, mas não sei se ainda fica ou se não fica mais.

c - O clube ficava no topo da colina, mas não fica mais.

Nesse caso também, a implicação de acabamento só valerá se não houver nada que a suspenda. $O$ mesmo raciocínio pode ser feito em relação às frases com a perífrase "ser + de + infinitivo" no pretérito perfeito do indicativo (cf. exemplos 266 e 296).

\subsubsection{8 - DuRATIVO E ACABADO, COMEÇADO E NÃO COMEÇADO}

O não começado só aparece junto ao durativo para situações diferentes em frases como (34), (37), (132), (259) uma das quais transcrevemos abaixo.

37. Este livro ficou por ler, pois não tive tempo.

a) S.R.: "ficou por ler" - perfectivo, durativo.

b) S.N.: "ler" - não começado.

O começado ou não acabado frequentemente aparece junto ao durativo para a mesma situação. Podemos observar isto em frases como (8a, b), (11a), (38), (39), (49), (65), (70), (72 a 75), (120a), (126), (128), (250), (252), (259), (262), (282), algumas das quais transcrevemos abaixo.

8a. $\quad$ Ele estava nadando desde as 6 horas.

11a. José lia um romance quando sua irmã chegou.

38. Os rapazes continuam jogando apesar da chuva.

72. Tenho a lição estudada.

120a. Tenho amado você e mais ninguém.

250. A tábua está lixada.

O começado ou não acabado aparece pouco junto ao durativo para situações diferentes. Isto ocorre, por exemplo, em frases como (249). 
O acabado também aparece frequentemente junto ao durativo para a mesma situação. Isto se pode observar em frases como (42), (58), (71), (82), (122a), (139), (140), (143) e (260), por exemplo. Abaixo transcrevemos três destes exemplos.

42. $\mathrm{O}$ treinador do time esteve doente.

58. A menina esteve balançando lá fora por muito tempo.

71. O pobre animal morreu pouco a pouco.

O acabado aparece ao lado do durativo também para situações diferentes em frases como (72 a 75), (128), (250), (262) e (282), por exemplo.

Cremos ter descrito aqui todas as relações possíveis entre os aspectos que constituem o quadro aspectual do Português. Estas relações estão resumidas no quadro IV na página seguinte. As relações que nos mostram que aspectos podem aparecer juntos para uma mesma situação são, naturalmente, as mais importantes, porque a partir delas e utilizando o QUADRO IV podemos saber se uma situação pode ou não ser apresentada com uma dada combinação de aspectos. Assim, por exemplo, suponhamos que se queira saber se uma situação pode ser apresentada com os aspectos "perfectivo, pontual e não começado". Verificando no quadro IV vemos que perfectivo e pontual aparecem juntos, mas que nem o perfectivo e nem o pontual podem aparecer juntos ao não começado para a mesma situação. Assim sendo, verifica-se que não temos uma situação apresentada com a combinação de aspectos acima.

\section{3 - A DISTINÇÃo ENTRE SITUAÇÃo NARRADA E REFERENCIAL E A ANÁLISE ASPECTUAL}

Como se pôde observar na descrição das relações entre os aspectos, a distinção entre situação narrada e referencial é extremamente importante. Apenas por meio dela podemos explicar a presença, em uma mesma forma, de aspectos muitas vezes opostos e incompatíveis, já que não se pode conceber, por exemplo, uma situação como acabada e não acabada ao mesmo tempo. Este parecia ser o caso da situação expressa em frases como (74), (75) e (250); mas a distinção entre situação narrada e referencial na análise aspectual mostrou-nos que, em frases como estas, temos aspecto não acabado para o estado expresso (situação referencial) e aspecto acabado para a ação (situação narrada) de cuja conclusão resultou o estado. A observação de várias análises aspectuais feitas na descrição das relações dos aspectos mostra a importância da distinção desses dos tipos de situação.

$\mathrm{Na}$ análise aspectual, sempre que encontramos uma forma onde temos uma situação narrada e uma referencial, é preciso especificar o aspecto de cada uma, para evitar qualquer problema de análise e compreensão. 
O aspecto verbal no Português: a categoria e sua expressão

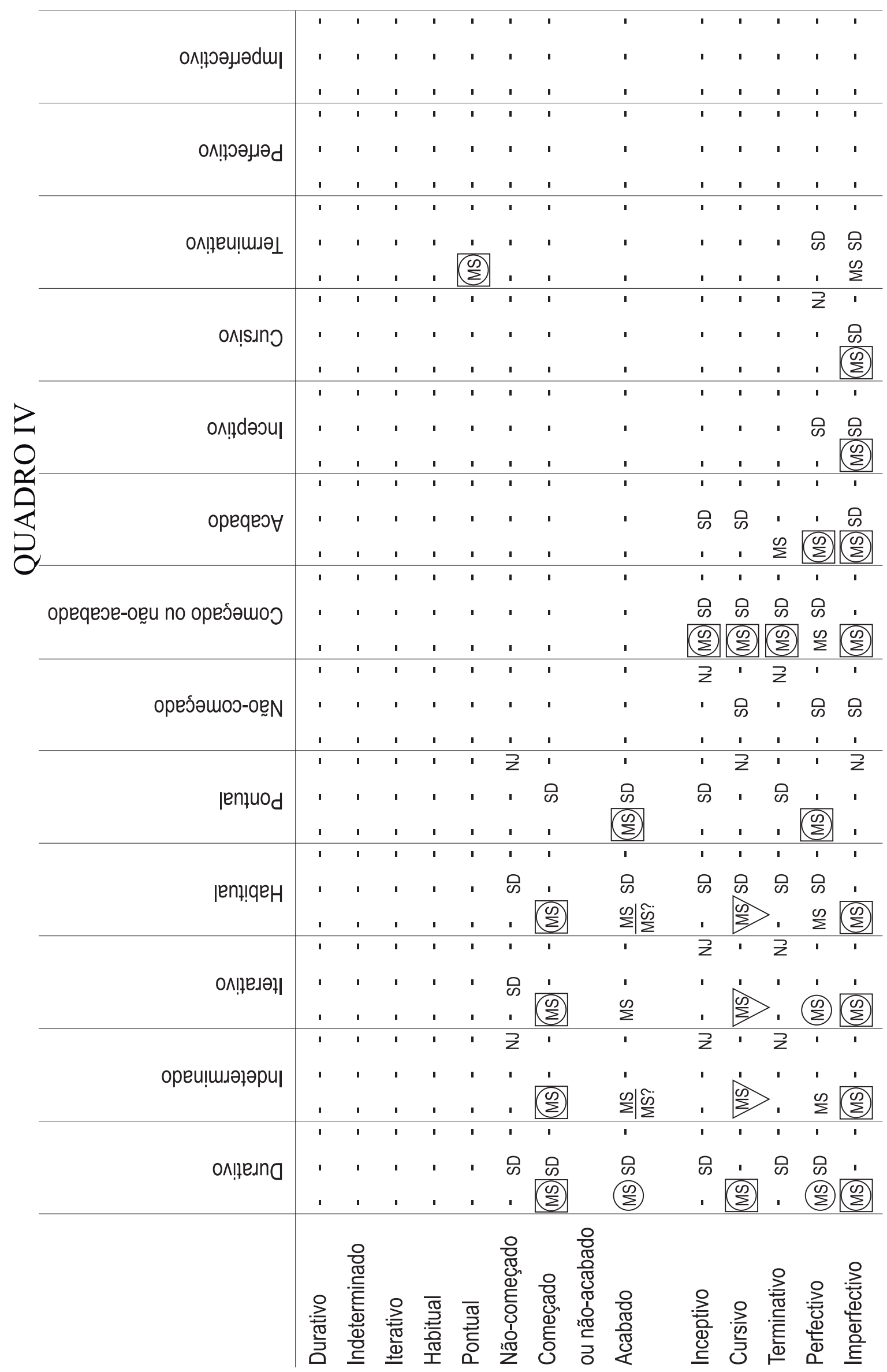




\section{6 - $\mathrm{O}$ aspecto nos nomes}

Normalmente o aspecto é apresentado como uma categoria nitidamente verbal, porque é nele que normalmente se concentra a expressão da situação, entretanto parece que podemos ter aspecto também nos nomes.

Dubois et al. (1978, p.73, grifo nosso) define o aspecto como "uma categoria gramatical que exprime a representação que o falante faz do processo expresso pelo verbo (ou pelo nome de ação), isto é, a representação de sua duração, do seu desenvolvimento ou do seu acabamento [...]".

Pela definição dada poderíamos pensar que Dubois admite o aspecto em nomes como "marcação", "violação", "nomeação", mas ele não exemplifica.

Comrie (1976) registra que, em algumas línguas, certos derivados nominais têm uma distinção aspectual clara como é o caso, por exemplo, de thieving (significado Imperfectivo) versus theft (significado Perfectivo) no inglês. ${ }^{1}$

No Português parece haver algumas oposições aspectuais nos nomes. Eis alguns exemplos:

a. muitos substantivos apresentam situações como durativas ou pontuais, como dinâmicas ou estados, assim temos por exemplo:

300. Explosão - é um evento (pontual)

301. Festa - é um processo (durativo)

302. Paz - é um estado (durativo)

Mas, como nos verbos, o fato de uma situação ser um evento, um processo ou um estado não nos permite falar na presença de aspecto pontual ou durativo.

b. ao que parece a oposição entre acabado/não acabado existe em pares de substantivos tais como:

${ }^{1}$ Exemplo de Seuren (1974) apud Comrie (1976, p.40, nota 1) 


$\begin{array}{lll} & \text { Não acabado } & \text { Acabado } \\ \text { 303. } & \text { mordeção } & \text { mordedura } \\ 304 . & \text { queimação } & \text { queimadura } \\ 305 . & \text { assação } & \text { assadura } \\ 306 . & \text { rachação } & \text { rachadura } \\ 307 . & \text { escravização } & \text { escravatura }\end{array}$

Os nomes da primeira coluna, geralmente de uso popular, indicam uma situação não acabada, em curso; enquanto os da segunda coluna indicam o resultado de uma situação acabada. A colocação em frases pode deixar mais clara a oposição. Veja as frases (308) e (309).

308. Essa queimação no estômago me deixa louco! (isto é, o estômago estar queimando).

309. O sol na praia queima muito. Para evitar queimaduras use um bom óleo. (Isto é para evitar o resultado do fato de ter queimado).

c) Os adjetivos terminados em -NTE, tais como corrente, nascente, constituinte, residente, por exemplo, têm frequentemente um valor cursivo que se percebe mais claramente em frases como (310) a (313) abaixo.

310. Há água corrente (= que corre) bem perto daqui.

311. Encontrei-a na janela contemplando o sol nascente (= que estava nascendo).

312. Os elementos constituintes (= que constituem, que estão constituindo) da comissão merecem a inteira confiança do presidente.

313. João Silva, casado, motorista, residente (= que reside, que está residindo) nesta cidade, vem requerer...

Estes mesmos adjetivos parecem ter um valor aspectual de começado ou não acabado que fica nítido quando eles são opostos ao particípio (que também é uma forma de valor adjetivo) do mesmo verbo que lhes serve de base.

$\begin{array}{ll}\text { Começado ou } & \text { Acabado } \\ \text { não acabado } & \\ & \\ \text { nascente } & \text { nascido } \\ \text { corrente } & \text { corrido } \\ \text { constituinte } & \text { constituído }\end{array}$


d) os adjetivos em -VEL têm um valor de não começado que se percebe claramente em exemplos tais como constituível, tocável, lavável, etc.

Se levarmos em conta os adjetivos terminados em -NTE e os particípios (de valor adjetivo), observamos haver formas adjetivas marcando exatamente as três fases de realização da situação. Veja abaixo:

$\begin{array}{lll}\text { Não começado } & \begin{array}{l}\text { Começado ou } \\ \text { não acabado }\end{array} & \text { Acabado } \\ \text { constituível } & \text { constituinte } & \text { constituído } \\ \text { tocável } & \text { tocante } & \text { tocado } \\ \text { falável } & \text { falante } & \text { falado }\end{array}$

Não deve passar despercebido que tanto os substantivos quanto os adjetivos, aqui apresentados como contendo valores aspectuais, são derivados de verbos.

Sobre o aspecto nos nomes limitar-nos-emos apenas a estas observações, porque um estudo sobre tal questão seria objeto para um outro trabalho. Fica aqui a sugestão. 



\section{PARTe II}

\section{Preliminares aos capítulos da $2^{\mathrm{a}}$ parte}

Nosso objetivo nesta parte é mostrar: a) que elementos participam da expressão do aspecto em Português e como o fazem; b) de que maneira o aspecto se relaciona com as categorias verbais de tempo, modo e voz; e, menos detidamente, c) como o aspecto pode influir na estruturação da frase, explicando a agramaticalidade em muitos casos. A consecução deste último objetivo não será feita em um bloco expositivo, mas no corpo de todo o trabalho. Na verdade, alguns elementos que a ele se ligam já foram expostos na primeira parte.

Sobre a expressão do aspecto, convém ressaltar, antes de mais nada, que há muito já se disse que o aspecto é expresso não apenas por elementos morfológicos. Verkuyl (1972, p.8), por exemplo, declara que muitas línguas podem ter desenvolvido meios não morfológicos de expressão do aspecto e, argumentando que o aspecto tem muito a ver com a sintaxe, cita vários autores que advogaram para esta categoria uma natureza predominantemente sintática, tais como Herbig, Poustma, Jacobsohn e Overdiep. ${ }^{1}$ Entre os autores que trataram da questão no Português, Castilho (1967, p.14) declara:

[...] Consideramos o aspecto uma categoria de natureza léxico-sintática, pois em sua caracterização interagem o sentido que a raiz do verbo contém e elementos sintáticos tais como adjuntos adverbiais, complementos e tipo oracional.

Câmara Júnior (1974b, p.145-146) deixa claro que, na falta de elementos morfológicos para expressão de aspecto, a língua desenvolve outros recursos para isto.

\footnotetext{
${ }^{1}$ HERBIG, G. Aktionsart und Zeitstufe. Beitrage zur Funktionslehre des Indogermanischen Verbums. Indogermanische Forschungen, Strassburg, v. 6, p.157-269, 1896.; JACOBSOHN, H. Aspektfragen. Indogermanische Forschungen, Strassburg, v. 51, p.292-318, 1933.; OVERDIEP, G. S. Stilistische grammatica van het moderne Nederlandsch. Zwolle: [s.n.], 1937.; POUSTMA, H. A grammar of late modern english. II: The parts of speech, section II. The verb and the particles. Groningen: [s.n.], 1926 apud VERKUYL (1972).
} 
Não vamos nos estender aqui numa exposição sobre o histórico do estudo da expressão do aspecto, explicitando as colocações existentes sobre a questão. Interessa apenas colocar que a expressão do aspecto depende não só de elementos morfológicos, mas também de elementos sintáticos, semânticos, mesmo fonológicos, e muitas vezes contextuais, seja o contexto linguístico ou não.

Nos estudos sobre o aspecto no Português, especificados no item 1.3, os autores apontam como meios que atuam na expressão do aspecto: a flexão verbal, as perífrases verbais, o semantema do verbo (sentido próprio do verbo), os afixos (alguns sufixos e prefixos), a repetição do verbo, os adjuntos adverbiais, o tipo oracional e o complemento do verbo. Câmara Júnior (1974b, p.145) fala na expressão do aspecto por construções idiomáticas que ele não esclarece quais seriam, nem exemplifica. Entretanto à página 142, ele diz que na frase "cai, cai, balão, na rua do sabão [...]" o verbo aparece repetido "para indicar uma queda lenta (aspecto durativo)".

A seguir comentaremos a atuação de cada um destes recursos na expressão do aspecto, com particular atenção na flexão verbal e nas perífrases. Falaremos também da atuação de alguns elementos, normalmente não citados por outros autores, tais como as preposições, o sujeito do verbo e a ênfase entonacional.

Muitas vezes o aspecto resulta da ação conjunta de mais de um desses meios de expressão. Nestes casos, torna-se difícil separar e dizer que é um ou outro recurso que expressa o aspecto. Por essa razão, ao falar de um meio de expressão, frequentemente nos referiremos a outros, embora pretendamos agrupar o maior número de informações sobre cada recurso de expressão quando falarmos especificamente sobre ele. 


\section{7 - Expressão do aspecto pelas flexões verbais}

\section{1 - OBservaÇões geraIS}

Todos estão de acordo sobre o tempo e o aspecto coexistirem lado a lado e, juntos, comporem um sistema complexo de categorias dentro do paradigma de conjugação verbal, em que, conforme a língua, predomina o aspecto ou o tempo.

No Português, predomina o tempo no paradigma de conjugação verbal, mas observa-se pelo menos uma distinção de base aspectual: entre o pretérito imperfeito do indicativo (imperfectivo + passado) e o pretérito perfeito do indicativo (perfectivo + passado).

Muitos autores são cautelosos em vincular tempos flexionais a aspectos: Castilho (1967) prefere falar em tendência aspectual dos tempos. No item 1.3 vimos o que vários autores dizem sobre a expressão do aspecto pela flexão temporal. Em nossa opinião muito do que se disse é válido, mas algumas vinculações não existem tal como apresentadas.

Uma última observação que aparece é a de que as possibilidades de expressão do aspecto são maiores entre os tempos flexionais do passado, cuja nitidez afinaria com a objetividade da noção de aspecto. Também se nota que o aspecto aflora com maior clareza nos tempos do indicativo, que exprimem ações objetivas, porque o aspecto é uma categoria mais objetiva, rareando no subjuntivo; contudo aqui, como veremos, trata-se mais de uma influência do modo que do tempo.

\section{2 - Presente do indicativo}

O presente do indicativo normalmente expressa aspecto imperfectivo como se pode ver nos exemplos (12) a (15), (20), (25), (26), (27), (28), (30a), (31) a (33) e (314) a (317). 
314. Tenho muitos selos antigos.

315. Escrevo estas notícias às duas da manhã. (Numa carta)

316. Se você contar o que a preocupa, talvez eu possa ajudar.

317. Esta vida de trabalho que levas, pode prejudicar tua saúde.

Muitos autores afirmam que o presente do indicativo seria incompatível com a Perfectividade caracterizada pelo acabamento. ${ }^{1} \mathrm{O}$ presente por si não expressa o acabado, embora uma situação apresentada pelo presente do indicativo possa ter aspecto acabado marcado, por exemplo, pela locução adverbial NÃO... MAIS, como no exemplo (318).

\section{Roque não fala mais de você.}

No item 4.2.8, ao falar do aspecto pontual, vimos que o presente do indicativo pode expressar este aspecto, ao mesmo tempo que expressa o perfectivo, como se pode ver nos exemplos (215) a (220) e (274) a (276). ${ }^{2}$ Entretanto, uma vez que com o presente momentâneo, o pontual só aparece com verbos de evento, não podemos dizer que o presente do indicativo sozinho marca o pontual e o perfectivo, pois temos aí o concurso do semantema do verbo para a expressão do aspecto.

O cursivo é expresso pelo presente do indicativo em descrições simultâneas e principalmente na linguagem oral mais formal ou na escrita, que é sempre mais formal que a fala. Temos aspecto cursivo marcado pelo presente em frases como (314) a (317) e (319) a (322) abaixo.

319. Chove muito aqui. (frase falada a outrem no telefone, por exemplo, no momento em que a chuva está caindo).

320. João ama Marilda com veneração.

321. O paciente respira bem agora.

322. “[...] Tia Marina, eu estou com medo!” (A. M. Machado). ${ }^{3}$

\footnotetext{
${ }^{1}$ Castilho (1967, p.81) na nota 130 registra que, para Bassols de Climent, o presente é incompatível com a ação perfeita. Esta não é a opinião de Castilho que, à página 81, apresenta várias frases com o presente do indicativo, em que ele diz haver aspecto Perfectivo Pontual.

${ }^{2}$ Adrados (1954, p.267) argumenta para o grego, que é difícil demonstrar que o presente é sempre durativo. Para Adrados o presente, em alguns casos, seria neutro: nem durativo, nem pontual. (ADRADOS, F. R. El método estrutural y el aspecto verbal. Emerita: Boletin De Linguistica Y Filologia Clasica, Madrid, v. 22, p.258-270, 1954.).

${ }^{3}$ Exemplo (322) apud Cunha (1975, p.429).
} 
Embora o presente do indicativo marque o aspecto cursivo, os falantes preferem marcar este aspecto através de perífrase ESTAR + GERÚNDIO ou ES$\mathrm{TAR}+\mathrm{A}+$ INFINITIVO, pois há uma tendência para se interpretar a frase com o presente do indicativo como habitual, caso em que a cursividade praticamente se anula. Dias (1970, p.183-184) chama a atenção para este fato (cf. item 1.2.7). Isto significa que podemos expressar o cursivo com o presente do indicativo, mas que esta não é a forma mais natural e preferida de expressão da cursividade. Pode-se observar que o cursivo expresso pelo presente do indicativo é mais claro quando temos um verbo de situação estática (cf. exemplos 320 e 322).

O presente do indicativo apresenta a situação sempre com aspecto não acabado ou começado, exceto em três casos: quando está apresentando a situação com aspecto pontual, pois, neste caso, não há marcação para a oposição acabado/ não acabado; ou quando há interferência de um outro elemento, como um adjunto adverbial, por exemplo, (cf. exemplo 318); ou quando o presente não está marcando nenhum aspecto (cf. adiante neste item).

$\mathrm{O}$ aspecto indeterminado normalmente é marcado pelo presente do indicativo, como se pode ver nos exemplos (12) a (15) e (172) a (182). Como já vimos, quando temos aspecto indeterminado, o aspecto imperfectivo e o cursivo presentes na mesma frase praticamente se anulam. O fato de que o indeterminado é expresso basicamente pelo presente do indicativo levou vários autores a registrar as "funções" de frases com aspecto indeterminado como funções principalmente do presente do indicativo, mas também do pretérito imperfeito do indicativo que é outro tempo que pode marcar o indeterminado (cf. item 1.2.3).

Muito frequentemente o habitual é marcado pelo presente do indicativo, de tal forma que muitos autores, mesmo sem estar falando de aspecto, anotaram que este tempo marca a habitualidade (cf. item 1.2.5). Temos o habitual marcado pelo presente em exemplos tais como (26), (27), (30a), (31) a (33), (204), (205) e (323) a (325) abaixo.

323. Tu só bebes água pura.

324. "Acordo cedo, tomo uma xícara de café, pequena, faço a barba, vou ao banho". (G. Ramos) $)^{4}$

325. Ele janta às 17 horas.

${ }^{4}$ O exemplo (323) é de Said Ali (1964, p.161). (SAID ALI, M. Gramática secundária da língua portuguesa. São Paulo: Melhoramentos, 1964. 249 p.). Exemplo (324) apud Cunha (1975, p.430). 
A habitualidade expressa pelo presente do indicativo frequentemente é reforçada por um elemento adverbial (adjunto ou oração) que torna a habitualidade mais clara e patente. Ao mesmo tempo, este elemento enfraquece a cursividade, cortando a possibilidade de se interpretar a frase como tendo aspectos durativo e cursivo. Podemos observar essa ação dos elementos adverbiais na habitualidade marcada pelo presente do indicativo nos exemplos (20), (25), (28), (197), (207) e (326) a (329) abaixo.

326. Todas as manhãs tomo um banho frio.

327. Normalmente ele já está no escritório às nove horas.

328. Eu sempre venho a este restaurante.

329. Ele me visita sempre que vem aqui.

O presente do indicativo, quando apresenta uma situação com aspectos imperfectivo e cursivo, pode apresentá-la também como durativa. É o que ocorre, por exemplo, nas frases (314) a (317), (330) e (331) abaixo.

330. André está satisfeito com o novo emprego.

331. Eles moram em Curitiba.

Nestes casos, temos sempre um processo ou um estado e não podemos dizer que o presente do indicativo marca sozinho o aspecto durativo.

Como vimos, o presente do indicativo em si marca os aspectos indeterminado, habitual, não acabado, cursivo e imperfectivo. Em conjunto com outros meios (adjuntos adverbiais, valor do semantema etc.) pode apresentar a situação com aspectos tais como o durativo, o pontual, o acabado e o perfectivo.

Em alguns casos o presente do indicativo não atualiza nenhum aspecto. Isto ocorre por exemplo:

a. quando o presente do indicativo é usado com valor de futuro como nos exemplos (332) a (335) abaixo.

332. Hoje à tarde vou a sua casa. ${ }^{5}$

333. Amanhã compro o livro para você.

334. O ônibus chega daqui a meia hora.

335. Conserto isto para você na semana que vem.

${ }^{5} \mathrm{O}$ verbo ir no presente do indicativo parece que raramente indica aspecto por ter, quase sempre, valor futuro. 
b. quando o presente do indicativo é usado pelo pretérito imperfeito do subjuntivo em frases do tipo de (336) a (338) abaixo.

336. Se respondo mal, ele se zangaria. ${ }^{6}$

337. Se o jumento corre por ali fora, contundia-me deveras. (Machado de Assis)

338. Se seu pai pega você, te matava de pancadas.

c. quando o presente do indicativo aparece na oração subordinada adverbial temporal que condiciona a habitualidade de outra situação. Isto pode ser observado nos exemplos (329), reescrito abaixo, (339) e (340).

329. Ele me visita sempre que vem aqui.

339. Quando o deixam sozinho, ele chora.

340. Toda vez que ele falta, acontece algo.

Como se pode observar, nas situações representadas pelos verbos sublinhados não há atualização do aspecto (e nem do tempo), havendo referência apenas à situação em si;

d. quando o presente do indicativo aparece na interrogativa em que se pergunta o que deve fazer o sujeito do verbo, ou se alguém fará algo. Neste caso, a categoria de tempo também se apaga e há referência apenas à situação em si. Veja exemplos (341) a (343).

341. Bato à porta?

342. Mãe, a senhora compra um carrinho para mim?

343. Você arruma esta máquina para mim?

Nestas frases há uma certa ideia de futuro, já que a situação ocorrerá após o momento de fala. Esse valor de futuro talvez seja a explicação para a não expressão do aspecto (cf. item 10.2);

e. quando o presente do indicativo é usado pelo imperativo, para atenuar a rudeza da ordem. Veja exemplos (344) a (347).

\footnotetext{
${ }^{6}$ O exemplo (336) é de Bechara (1977, p.274). (BECHARA, E. Moderna gramática portuguesa. São Paulo: Nacional, 1977.). Exemplo (337) apud Cegalla (1976, p.375).
} 
344. Você vem comigo. (= Venha você comigo).

345. O senhor me resolve o problema. (= Resolva-me o problema).

346. Paulo, você me dá a pinça (= dê-me a pinça) e você, Marlene, segura a cabeça dele (= segure a cabeça dele).

347. Ninguém desce do caminhão até eu ver que está tudo bem. (= ninguém desça).

\section{3 - Pretéritos imperfeito e Perfeito do indicAtivo}

No estudo da expressão do aspecto pelos tempos flexionais, um ponto que chama logo a atenção é a distinção aspectual entre o pretérito imperfeito e o pretérito perfeito do indicativo. Vários estudiosos já fizeram referência a esta distinção, dizendo que o pretérito imperfeito marca o aspecto imperfectivo e o pretérito perfeito marca o aspecto perfectivo, embora nem sempre o digam assim claramente.

Sobre a validade da distinção:

384. a - pretérito imperfeito do indicativo - imperfectivo

b - pretérito perfeito do indicativo - perfectivo

Não paira qualquer dúvida. É suficiente observar as frases em que estes tempos estão presentes e veremos que, nas frases com pretérito perfeito, a situação é sempre apresentada como preenchendo um período de tempo completo, ou como uma situação que ocorre em um momento. Já nas frases com pretérito imperfeito, a situação é apresentada como preenchendo um período de tempo que ainda não é completo.

Vem daí a seleção de formas a que Pontes (1972, p.80-84) aludiu: o pretérito perfeito (aspecto perfectivo) ${ }^{7}$ exige adjuntos adverbiais de tempo que indicam períodos de tempo determinados e/ou completos, e o pretérito imperfeito (aspecto imperfectivo) aceita adjuntos adverbiais de tempo que indicam períodos de tempo indeterminados e/ou incompletos (cf. o que dissemos a respeito no item 4.2.3). Exemplos:

349. a - Ele correu há cinco horas. (É pontual e determinado)

b - Ele corria há cinco horas. (Havia já cinco horas que estava correndo - é incompleto) ${ }^{8}$

\footnotetext{
${ }^{7}$ Pontes (1972) não fala em perfectivo e imperfectivo. Fizemos a transposição com base nos exemplos apresentados pela autora.

${ }^{8}$ Se o adjunto adverbial for tomado como pontual em exemplos como (349b) e (166b), a frase terá valor cursivo e o adjunto adverbial marcará um momento em que a situação estava ocorrendo. Esta interpretação embora possível não é a mais natural.
} 
350. a - Ele correu cinco horas. (É completo)

b - Ele corria cinco horas. (Esta frase só é válida no sentido iterativo em que cada realização da situação tem duração de cinco horas).

351. a - Ele morreu em janeiro. (Um janeiro determinado).

b - As flores morriam em janeiro. (Janeiro é indeterminado e a frase só vale no sentido iterativo).

O pretérito perfeito não marca nenhum aspecto ligado à fase de desenvolvimento já que é sempre perfectivo. O pretérito imperfeito, em si, marca apenas o cursivo, como veremos adiante.

O pretérito perfeito em si não expressa nenhum aspecto caracterizado pela duração ou não duração. Muitos autores (cf. capítulo 1) afirmam que o pretérito perfeito apresenta a situação como pontual, mas isto na verdade não acontece. $\mathrm{O}$ que temos é uma abstração da duração, porque esse tempo é sempre perfectivo (cf. o que dissemos no item 4.2.8). ${ }^{9} \mathrm{O}$ pretérito perfeito marca o aspecto pontual, por exemplo, quando o verbo é de situação estritamente pontual, como acontece nos exemplos (221), (222), (277) a (280) e (352) abaixo.

352. Paulo arrebentou o cordão sem dificuldade.

Já o aspecto durativo será marcado quando temos o pretérito perfeito de um verbo de estado como em (42), (82), (143), (263) e (353) abaixo.

353. Seu pai esteve preocupado com os negócios.

O durativo também aparece com o pretérito perfeito quando a duração é marcada por um adjunto adverbial ou oração adverbial temporal. É o que se dá em frases como (10), (71), (146) e (354) a (356) abaixo.

354. Antônio procurou você durante a tarde toda.

355. Ele ensaiou esta música o dia todo.

356. Ele leu o artigo enquanto esperava sua vez no dentista.

\footnotetext{
${ }^{9}$ IMBS (1960, p.86) afirma que o "passé simple", equivalente francês do pretérito perfeito, "n'exclut pas la durée, mais il en fait abstraction, quitte à l'exprimer par un moyen lexical" (não exclui a duração, mas faz abstração dela, deixando que um meio lexical a exprima).
} 
Uma evidência de que nestes casos é o adjunto adverbial o responsável pela presença do aspecto é o fato de no exemplo (71) termos o durativo a despeito de termos um evento no pretérito perfeito do indicativo.

Também a repetição do verbo pode nos dar o aspecto durativo com o pretérito perfeito. É o que vemos nos exemplos (139), (140), (265) e (357) abaixo.

357. Marta aprontou-se, aprontou-se e depois resolveu não sair mais.

Naturalmente, em todos os casos acima o pretérito perfeito não marca os aspectos durativo ou pontual. Estes aparecem graças ao semantema verbal, ao adjunto adverbial ou à repetição do verbo.

Também o iterativo e o habitual só aparecem com o pretérito perfeito por influência de adjuntos adverbiais (cf. no item 1.2.4 o que diz Cunha, 1975 sobre o fato). Fica claro que é o elemento adverbial e não o tempo que marca a iteratividade ou a habitualidade. Veja exemplos (187), (271), (358) e (359) para o iterativo e frases do tipo de (360) para o habitual.

358. Ele falou comigo várias vezes. (iterativo)

359. Liguei várias vezes na sua casa hoje e ninguém atendeu. (iterativo)

360. Aquele menino sempre desobedeceu aos pais. (habitual)

Já o pretérito imperfeito é essencialmente durativo (cf. no item 1.2.2 o que dizem vários autores, embora não estejam tratando de aspecto). Veja exemplo (361) abaixo.

361. Ele caminhava pelas ruas, quando teve uma ideia. (imperfectivo, durativo, cursivo, não acabado)

Mesmo o verbo sendo um evento, o pretérito imperfeito apresenta a situação como durativa. Veja os exemplos (362) e (363).

362. Josué pulava o muro quando viu o cachorro.

363. A pobre ave morria por falta de água.

Quando marca o durativo, o pretérito imperfeito marca também o cursivo, pois indica estes dois aspectos, principalmente quando a situação que expressa é presente a uma outra situação passada, ou seja, é uma situação que estava se pro- 
cessando quando outra sobreveio. Esta situação que ocorreu, quando a outra no pretérito imperfeito estava se desenvolvendo, é introduzida normalmente por uma oração temporal com o verbo no pretérito perfeito, como nos exemplos (361) e (362). A situação no pretérito imperfeito pode ser também "presente" a um determinado momento do passado expresso por adjunto adverbial como em (364) e (365).

364. Ele falava às dez horas.

365. Ele chegava às oito horas e o chefe o repreendeu.

Frases do tipo de (364) e (365), em que a presentificação é feita por um adjunto adverbial, são ambíguas, podendo ter duas interpretações: uma durativa, cursiva e outra habitual. A tendência maior é para considerar a interpretação habitual, pois o falante, neste caso, prefere marcar o durativo e o cursivo lançando mão de uma perífrase ${ }^{10}$ e dizendo:

366. Ele estava falando às dez horas.

367. Ele estava chegando às oito horas, e o chefe o repreendeu. ${ }^{11}$

Essa ambiguidade pode ser eliminada por um adjunto adverbial de frequência, que torna a frase apenas habitual. Veja exemplos (368) e (369).

368. Ele sempre falava às dez horas.

369. Ele chegava às oito horas todos os dias e o chefe o repreendeu.

Parece-nos que a única forma de garantir a interpretação durativa e cursiva é colocar o adjunto adverbial presentificador no início da frase, como em (370).

\section{0. Às dez horas ele falava.}

Contudo este processo sempre leva ao acréscimo da ideia de que queremos realçar que, num dado momento, a pessoa estava fazendo aquilo que o verbo no pretérito imperfeito indica, e não outra coisa.

Como já vimos, o pretérito imperfeito expressa também o aspecto habitual. À exceção das frases em que a situação expressa pelo verbo no pretérito imperfeito está presentificada a outra situação expressa por verbo no pretérito perfeito (como

\footnotetext{
${ }^{10}$ Veja no item 1.2.7 o que Dias (1970, p.183-4) diz a este respeito.

${ }^{11}$ As frases (366) e (367) também são passíveis de uma interpretação iterativa.
} 
nos exemplos 361 e 362), este tempo apresenta uma tendência para marcar a iteração habitual. Isto acontece principalmente quando o pretérito imperfeito, como já dissemos, vem sem presentificação (exemplos 371 e 375). Às vezes a habitualidade vem reforçada por adjuntos adverbiais como em (368), (369) e (372). A habitualidade também aparece quando a ocorrência da situação expressa pelo verbo no pretérito imperfeito está condicionada à ocorrência de outra situação, expressa por verbo também no pretérito imperfeito em uma oração adverbial temporal, como em (197), (373) e (374).

371. José esquecia objetos onde quer que fosse.

372. Às vezes chovia forte.

373. Quando eu virava as costas, eles gritavam.

374. Quando eu não atendia seu desejo, o menino chorava como um louco.

(375) Mamãe só comprava frutas do Sr. José.

Como há uma estreita relação entre o hábito e a caracterização do indivíduo que o possui, temos muitas frases de aspecto habitual marcado pelo pretérito imperfeito e com a função de caracterização. Veja exemplos (376) e (377).

376. José fumava muito.

377. Paulo gesticulava grotescamente.

$\mathrm{O}$ aspecto indeterminado também pode ser marcado pelo pretérito imperfeito, o que acontece em frases como (18), (19), (269), (270) e (378), (379) abaixo.

378. Maria tinha uma pinta no rosto.

379. Aquele menino era um anjo.

Até agora vimos os aspectos expressos pelos pretéritos imperfeito e perfeito do indicativo, ligados ao completamento, à duração e à fase de desenvolvimento. Falta-nos ver que aspectos ligados à fase de realização eles expressam.

Neste caso, entretanto, o julgamento sobre o aspecto expresso não é tão tranquilo se considerarmos a interferência que têm os seguintes fatores: a) a falsa suposição de que tudo o que é apresentado como passado é também acabado. Daí a tendência para pensar que os dois tempos, sendo passados, apresentam a situação como acabada; b) o fato de que o pretérito imperfeito expressa sempre o imperfectivo 
e o pretérito perfeito expressa sempre o perfectivo. Assim sendo, é natural pensar que o pretérito imperfeito, apresentando a situação como incompleta, expresse o aspecto não acabado, enquanto o pretérito perfeito, apresentando a situação como completa, expresse o aspecto acabado. Veja no capítulo 1 que quase todos os autores dizem que o pretérito imperfeito apresenta a situação como não acabada, inconclusa e que o pretérito perfeito a apresenta como acabada, conclusa; c) o fato de o falante ter uma tendência para interpretar o habitual e o indeterminado passados como acabados (cf. o que dissemos nos itens 5.2.15 e 5.2.17).

A ação conjunta desses fatores acaba por criar um sistema não muito bem estabelecido e torna-se difícil falar com segurança na expressão do aspecto acabado e não acabado pelo pretérito imperfeito e pelo pretérito perfeito do indicativo. Estes dois tempos em si não expressam o aspecto não começado em nenhuma circunstância.

Sejam as frases:

380. a - Marcos era professor. b - Marcos foi professor.

381. a - José estava doente. b - José esteve doente.

382. a - Maria estudava muito. b - Maria estudou muito.

383. a - Sérgio sempre escrevia bem. b - Sérgio sempre escreveu bem.

384. a - José lia o livro. b - José leu o livro.

Parece que podemos dizer sem dúvida que, nas frases (380b) e (381b), o aspecto é o acabado, o que confirma as expectativas de que o pretérito perfeito expressa este aspecto. Contudo, na frase (382b), não podemos afirmar com certeza se o aspecto é o acabado ou não, pois a frase não implica necessariamente que a situação acabou. Em (383b) parece-nos que há clara a ideia de situação não acabada, apesar do pretérito perfeito. Já em (384b), vemos que a situação é apresentada como acabada sem qualquer dúvida e que em (384a) não é. Comparando as frases de (382) e (384), vemos que em (382) o verbo é atélico e em (384) é télico. Daí possamos talvez dizer que, com verbos télicos, o pretérito perfeito do indicativo marca o acabado, mas não com os verbos atélicos. As frases (380a) e (381a), pronunciadas com entonação normal, parecem indicar situação não acabada em um determinado 
momento do passado, tanto que podemos acrescentar-lhes, respectivamente, os seguintes trechos:

a - mas não sei se ainda é.

b - mas não sei se ainda está.

sem criar qualquer estranheza nos falantes, o que já não acontece com (380b) e (381b). Se pronunciadas com ênfase entonacional no verbo, as frases (380a) e (381a) terão aspecto acabado. Adiante comentamos mais este fato. A frase (382a), à primeira impressão, parece não apresentar a situação nem como acabada, nem como não acabada, mas apenas como habitual, valor que, aliás, o pretérito imperfeito carrega quando não é presentificado a outra situação passada, como vimos. Em virtude desse valor habitual passado, há uma certa tendência em ver (382a) como tendo aspecto acabado (a esse respeito já argumentamos no item 5.2.15). Já em (383a), sentimos a situação como acabada, além de ser habitual, embora tenhamos pretérito imperfeito.

Nas frases (380), (381) e (384), com verbos de estado e télicos, as expectativas com relação à expressão dos aspectos acabado e não acabado pelos pretéritos perfeito e imperfeito do indicativo parecem se confirmar: o pretérito perfeito marca o acabado e o pretérito imperfeito o não acabado. Nas frases de (382), com verbo atélico, parece não haver expressão destes aspectos e nas frases de (383), com verbo atélico e adjunto adverbial de frequência, reforçando a habitualidade em (383a) e marcando-a em (383b), parece que temos o oposto do esperado: o pretérito imperfeito do indicativo, e não o pretérito perfeito, indicando o aspecto acabado.

Para não tirar conclusões com base apenas em nossa própria intuição de falante da Língua Portuguesa, em uma questão que se mostra problemática, elaboramos um questionário (cf. apêndice) e o submetemos a outros falantes da língua ${ }^{12}$ para verificar como estes sentiam a expressão dos aspectos acabado e não acabado pelos dois tempos em questão.

\footnotetext{
${ }^{12}$ Os itens I a IX do questionário foram respondidos por vinte e oito falantes. Destes, um tinha nível de estudos de $1^{\circ}$ grau, vinte e dois eram estudantes de Letras de $4^{\circ}$ e $5^{\circ}$ períodos (na computação dos dados um destes foi eliminado por não ter respondido convenientemente ao questionário) e cinco tinham curso completo de Letras. Os itens X e XI foram respondidos por vinte falantes: um com nível de estudos de $1^{\circ}$ grau, dois eram alunos do $2^{\circ}$ grau, cinco eram universitários não de Letras de $1^{\circ}$ e $2^{\circ}$ períodos, sete eram alunos de Letras de $5^{\circ}$ período e cinco eram universitários já formados (três professores, um economista e um médico). Não houve diferença entre os grupos.

O questionário foi aplicado em três etapas: primeiro os itens I a VI, em segundo lugar os itens VII a IX e por último os itens X e XI
} 
Os resultados obtidos estão registrados no QUADRO 5.

\section{Esclarecimentos sobre o quadro V:}

1. A expressão "em contraste" significa que se apresentaram aos falantes duas frases emparelhadas, cuja única diferença era o tempo do verbo ou um determinado elemento que aparece especificado no quadro. Nestes casos, "pedia-se" ao falante que apontasse a frase em que havia a ideia de acabado, ou que falasse a diferença de significado, ou que fizesse um julgamento sobre qual frase expressava uma ideia dada.

2. A expressão "sem contraste" significa que se apresentou a frase isoladamente ao falante e pediu-se que ele fizesse um julgamento que levava a perceber se via a frase como tendo aspecto acabado ou não acabado, ou como não marcada para esta oposição.

3. As porcentagens registradas no quadro $V$ são as médias aritméticas das porcentagens obtidas para cada um dos exemplos.

A partir dos resultados registrados no quadro $\mathrm{V}$ podemos tirar algumas conclusões e tecer alguns comentários. Para evitar repetições, não transcrevemos aqui exemplos dos questionários. Para utilizar a exemplificação, o leitor deverá dirigir-se ao questionário no apêndice, orientado pelos números citados no quadro $\mathrm{V}$ junto à especificação da situação em que as frases foram apresentadas aos falantes. Passemos aos comentários e conclusões:

1) Nos verbos de estado, o pretérito perfeito do indicativo é, sem dúvida, o tempo que marca o aspecto acabado (média de 83,5\%), embora para uma certa porcentagem de falantes seja o pretérito imperfeito que marca este aspecto. 


\begin{tabular}{|c|c|c|c|c|c|c|}
\hline \multirow{3}{*}{$\overline{\mathrm{N}^{\circ}}$} & \multirow{3}{*}{ Verbo } & \multicolumn{2}{|l|}{ QUADRO 5} & \multirow{2}{*}{\multicolumn{3}{|c|}{ Aspecto }} \\
\hline & & \multirow{2}{*}{ Situação } & \multirow[t]{2}{*}{ Tempo } & & & \\
\hline & & & & Acabado & $\begin{array}{l}\text { Não } \\
\text { acab. }\end{array}$ & $\begin{array}{c}\text { Não } \\
\text { Marcado }\end{array}$ \\
\hline \multirow[t]{7}{*}{ I } & \multirow[t]{7}{*}{ SER } & \multirow{2}{*}{$\begin{array}{l}\text { 1) Em contraste: Pret. Imp. x Pret. Perf. } \\
\text { (itens I.1, II.2, III.3 e IV.1) }\end{array}$} & a) Pret. imp. & $34 \%$ & & \\
\hline & & & b) Pret. perf & $72 \%$ & & \\
\hline & & \multirow{2}{*}{$\begin{array}{l}\text { 2) Sem contraste (itens VI.4 e VI.6 do } \\
\text { questionário) }\end{array}$} & a) Pret. imp. & $61 \%$ & $12 \%$ & $27 \%$ \\
\hline & & & b) Pret. perf & $84 \%$ & $4 \%$ & $12 \%$ \\
\hline & & \multirow{3}{*}{$\begin{array}{l}\text { 3) Em constraste: Pret. Imp. Simples x Pret. } \\
\text { Imp. com opos. antes/agora x Pret. Perf (item } \\
\text { IV.5 do questionário) }\end{array}$} & $\begin{array}{l}\text { a) Pret. imp. } \\
\text { Simples }\end{array}$ & $22 \%$ & & \\
\hline & & & $\begin{array}{l}\text { b) Pret. imp } \\
\text { c/ opos. ant } \\
\text { agora }\end{array}$ & es- & & \\
\hline & & & c) Pret. perf. & $48 \%$ & & \\
\hline \multirow[t]{4}{*}{ II } & \multirow[t]{4}{*}{ ESTAR } & \multirow{2}{*}{$\begin{array}{l}\text { 1) Em contraste: pretérito imperfeito x } \\
\text { pretérito perfeito (itens I.2, II.1, II.7, III.2 e } \\
\text { IV.3 do questionário) }\end{array}$} & a) Pret. imp. & $24 \%$ & & \\
\hline & & & b) Pret. perf. & $82 \%$ & & \\
\hline & & \multirow{2}{*}{$\begin{array}{l}\text { 2) Sem contraste (itens VI.1 e VI.3 do } \\
\text { questionário) }\end{array}$} & a) Pret. imp. & $56 \%$ & $7 \%$ & $37 \%$ \\
\hline & & & b) Pret. perf. & $96 \%$ & & $4 \%$ \\
\hline \multirow[t]{20}{*}{$\overline{\text { III }}$} & \multirow{20}{*}{$\begin{array}{l}\text { VERBOS } \\
\text { NÃO DE } \\
\text { LIGAÇÃO } \\
\text { OU DE } \\
\text { ESTADO }\end{array}$} & \multirow{4}{*}{$\begin{array}{l}\text { 1) Em contraste: Pret. Imp. Simples x Pret. } \\
\text { Perf. Simples (itens VII.1, VII.4, VII.5, VII.6, } \\
\text { VIII.2 e VIII.6 para verbos télicos) (itens II.4, } \\
\text { III.4, VIII.1 e VIII.3 para verbos atélicos) }\end{array}$} & \multirow{2}{*}{$\begin{array}{l}\text { a) Pret. } \\
\text { imp. }\end{array}$} & $31 \%$ & & $10 \%$ \\
\hline & & & & \begin{tabular}{|ll} 
Atél. $\quad 70 \%$ \\
\end{tabular} & & $4 \%$ \\
\hline & & & \multirow{2}{*}{$\begin{array}{l}\text { b) Pret. } \\
\text { perf. }\end{array}$} & Tél. $\quad 71 \%$ & & \\
\hline & & & & Atél. $36,5 \%$ & & $10 \%$ \\
\hline & & \multirow{4}{*}{$\begin{array}{l}\text { 2) Sem contraste: (itens VI.7, IX.1, IX.3, IX.4 } \\
\text { e IX.6 para verbos atélicos) (itens IX.2, IX.5 } \\
\text { e IX.7 para verbos télicos) }\end{array}$} & \multirow{2}{*}{$\begin{array}{l}\text { a) Pret. } \\
\text { imp. }\end{array}$} & Tél. $\quad 50 \%$ & $15 \%$ & $35 \%$ \\
\hline & & & & Atél. $\quad 48 \%$ & $18 \%$ & $34 \%$ \\
\hline & & & \multirow{2}{*}{$\begin{array}{l}\text { b) Pret. } \\
\text { perf. }\end{array}$} & $96 \%$ & $2 \%$ & $2 \%$ \\
\hline & & & & \begin{tabular}{|ll} 
Atél. $\quad 65 \%$ \\
\end{tabular} & $8 \%$ & $27 \%$ \\
\hline & & \multirow{2}{*}{$\begin{array}{l}\text { 3) Em contraste: Pret. Imp. e Pret. Perf., } \\
\text { ambos com adj. adv. de freq. (itens I.3, I.4, } \\
\text { II.5, II.6, III.1, IV.2 e V) }\end{array}$} & $\begin{array}{l}\text { a) Pret. } \\
\text { imp. }\end{array}$ & $75 \%$ & & \\
\hline & & & b) Pret. perf. & $25 \%$ & $57 \%$ & \\
\hline & & \multirow{2}{*}{$\begin{array}{l}\text { 4) Sem contraste: Pret. Imp. e Pret. Perf., } \\
\text { ambos com adj. adv. de freq. (itens VI.2 e } \\
\text { VI. } 5 \text { do questionário) }\end{array}$} & a) Pret. imp. & $52 \%$ & $15 \%$ & $30 \%$ \\
\hline & & & b) Pret. perf. & $12 \%$ & $73 \%$ & $15 \%$ \\
\hline & & \multirow{4}{*}{$\begin{array}{l}\text { 5) Em contraste: Pret. Imp. Simples x Pret. } \\
\text { Imp. com adj. adv. de freq. (itens II.3, VII.3, } \\
\text { VIII.4, para verbos atélicos) (itens X.2, X.3, } \\
\text { X.4, XI.2, XI.3, XI.4 para verbos télicos) }\end{array}$} & \multirow{2}{*}{$\begin{array}{l}\text { a) Pret. } \\
\text { imp. } \\
\text { simples }\end{array}$} & $39 \%$ & & $13,5 \%$ \\
\hline & & & & Atél. $\quad 49 \%$ & & $27 \%$ \\
\hline & & & \multirow{2}{*}{$\begin{array}{l}\text { b) Pret. } \\
\text { imp. c/ } \\
\text { adj.adv. } \\
\text { de freq. }\end{array}$} & Tél. $\quad 47,5 \%$ & & $13,5 \%$ \\
\hline & & & & Atél. $\quad 34 \%$ & & $27 \%$ \\
\hline & & 6) Em contraste: a) Pret. Imp. Simples $x$ Pret. & a) Pret. & Tél. $\quad 47,5 \%$ & & $25 \%$ \\
\hline & & $\begin{array}{l}\text { Imp. Presentificado (itens IV.4, VII.2 e VIII.5 } \\
\text { para verbos atélicos) (itens X.1, X.5, XI.1 e }\end{array}$ & $\begin{array}{l}\text { imp. } \\
\text { simples }\end{array}$ & $\begin{array}{|ll|}\text { Atél. } \quad 43 \% \\
\end{array}$ & & 18,5 \\
\hline & & XI.5 para verbos télicos) & b) Pret. & Tél. $\quad 27,5 \%$ & & $25 \%$ \\
\hline & & & $\begin{array}{l}\text { presen- } \\
\text { tificado }\end{array}$ & Atél. $43,5 \%$ & & $18,5 \%$ \\
\hline
\end{tabular}


Em 3.1 dissemos que os verbos estáticos entre eles os de estado, apresentavam certos comportamentos de verbos télicos. A indicação de aspecto acabado (com ideia de cessamento) com o pretérito perfeito do indicativo é o principal deles (ver conclusão 2 abaixo).

É bom lembrar que o pretérito imperfeito do indicativo de verbos estáticos marca sem dúvida o aspecto acabado, quando, na língua falada, é enfatizado dentro da frase pela entonação. Neste particular os verbos de estado são semelhantes aos verbos atélicos e diferentes dos verbos télicos. Este fato talvez explique porque na situação "sem contraste", nos itens I.2.a e II.2.a do quadro V, temos porcentagens relativamente altas para o pretérito imperfeito como marcador de aspecto acabado (respectivamente $61 \%$ e $56 \%$ ). Explicaria porque, quando a frase de pretérito imperfeito aparece isolada, parece haver uma tendência para dizê-la com ênfase do verbo. No caso do verbo ser (item I.2.a do quadro V), a porcentagem alta do pretérito imperfeito como marcador do acabado pode também se explicar pelo fato de que o tipo de frase apresentado, semelhante a (385) abaixo, normalmente tem aspecto indeterminado ${ }^{13} \mathrm{e}$, como já dissemos (cf. item 5.2.17), o falante tem uma tendência para interpretar o indeterminado passado como acabado.

\section{Carla era nadadora.}

Observando os resultados para o verbo ser registrados em I.3 no quadro V, vemos que frases com verbos de estado no pretérito imperfeito, onde se estabelece $o$ contraste antes/agora, como em (386) abaixo, têm aspecto acabado tanto quanto as frases com pretérito perfeito ( $52 \%$ para frases do primeiro tipo e $48 \%$ para o segundo).

386. Maria era inteligente, não é mais.

Nestes casos alguém poderia dizer que é o pretérito imperfeito que expressa o acabado. Castilho (1967, p.91), falando da expressão do perfectivo cessativo diz que o imperfeito é que marca o aspecto Cessativo (que é um acabado) no seguinte exemplo:

387. Antônio: “[...] eu sou um farrapo, tampa de valeta, um piolho!" Amália: "És? Ainda és isso, Antônio? [...]"

Antônio: "Era. Já não sou”. (B. Santareno)

\footnotetext{
${ }^{13}$ Como vimos no item 3.2, o verbo ser indica estados permanentes, isto é, com duração ilimitada e portanto sempre marca o aspecto indeterminado.
} 
Por extensão poderíamos dizer que o pretérito imperfeito do indicativo marca o aspecto acabado em todas as frases como (386) a (389), nas quais se estabelece o contraste entre antes e agora.

388. Ele falava de você, agora não fala mais.

389. Rafael comprava diamantes, mas não compra mais.

Entretanto não é o pretérito imperfeito que marca o acabado nestas frases. O que o faz é a locução adverbial NÃO... MAIS colocada junto ao presente do indicativo. A oração com o verbo no pretérito imperfeito representa apenas uma pressuposição (deduzida por implicação da oração com o presente do indicativo e a locução "não... mais") que foi explicitada no discurso, mas é perfeitamente dispensável, pois podemos dizer simplesmente:

390. Maria não é mais inteligente. (Há a pressuposição de que "Maria era inteligente")

391. Não sou mais um farrapo, tampa de valeta, um piolho. (Há a pressuposição de que "Eu era um farrapo, tampa de valeta, um piolho")

392. Ele não fala mais de você. (Há a pressuposição de que "Ele falava de você")

393. Rafael não compra mais diamantes. (Há a pressuposição de que "Rafael comprava diamantes").

Como se vê, nas frases (390) a (393) continua havendo aspecto acabado e, portanto, quem marca o acabado em (386) a (389) não é o pretérito imperfeito, mas sim a locução adverbial "não...mais" colocada junto ao presente do indicativo. No exemplo (387), o contexto permitiu a omissão do termo mais da locução adverbial restando apenas a negativa, entretanto, sem o contexto, a presença do mais seria necessária.

Também em frases como (394) não é o pretérito imperfeito que marca o acabado. Na verdade, a situação é sentida como acabada, não porque haja algo que marque o aspecto acabado, mas por uma dedução da significação geral da frase. ${ }^{14}$

394. Naquele tempo ele falava essas coisas aos alunos, mas hoje limita-se a ensinar a matéria.

\footnotetext{
${ }^{14}$ É comum termos certas noções aspectuais que parecem ser consequência do significado total da frase e não podem ser localizadas em algum elemento da mesma, ou ser atribuídas a este ou aquele elemento.
} 
2) Com os verbos télicos o pretérito perfeito do indicativo é, sem dúvida, o tempo que marca o aspecto acabado. Isto é evidenciado pelas porcentagens registradas no quadro V, nos itens III.1.b e III.2.b, na situação "em contraste" (71\%), e principalmente na situação "sem contraste" ( $96 \%$ ), embora para uma certa porcentagem de falantes o tempo que expressa o acabado com estes verbos é o pretérito imperfeito (cf. os itens III.1.a e III.2.a do QUADRO 5). ${ }^{15}$ Era de se esperar que o pretérito perfeito de verbos télicos marcasse o aspecto acabado, pois neste caso temos resultatividade - 2 (cf. item 2.3).

$\mathrm{O}$ fato de certa porcentagem de falantes apontar o pretérito imperfeito como marcador do aspecto acabado com verbos télicos pode ser explicado se observarmos que as frases com pretérito imperfeito normalmente têm sentido habitual e lembrarmos que o habitual passado tende a ser interpretado como acabado. Esta parece ser realmente a explicação, pois, quando a frase com pretérito imperfeito é mais dificilmente sentida como habitual, como (395) abaixo, um menor número de falantes $(22 \%)$ vê nela aspecto acabado.

395. Roberto lia o livro. (frase VII.4.a do questionário).

3) Com os verbos atélicos na situação "em contraste" (cf. item III.1 do quadro V) o tempo que marca o aspecto acabado é o pretérito imperfeito ( $70 \%$ para este tempo contra $36,5 \%$ para o pretérito perfeito). Entretanto na situação "sem contraste" (cf. item III.a no quadro V), o pretérito perfeito foi apontado como o marcador do aspecto acabado com os verbos atélicos com uma porcentagem de $65 \%$ contra $48 \%$ para o pretérito imperfeito.

Estes resultados não nos permitem chegar a uma colocação definitiva ou pelo menos mais segura, mas podemos falar de uma tendência para ver o pretérito imperfeito como marcador de aspecto acabado com os verbos atélicos. Isto se explica porque as frases com o pretérito imperfeito são normalmente habituais, como os exemplos (396) a (399), e como o pretérito perfeito dos verbos atélicos não marca o acabado, pois aí não há resultatividade -2 , cresce a tendência para interpretar o habitual passado como acabado.

\footnotetext{
${ }^{15} \mathrm{O}$ resultado obtido para o exemplo registrado no questionário sob o número VIII - 6:

a) Os trabalhadores partiam de manhã.

b) Os trabalhadores partiram de manhã.

contradiz essa tendência geral dos falantes para considerarem o pretérito perfeito do indicativo como marcador de aspecto acabado com verbos télicos. $67 \%$ dos falantes apontou a frase a como tendo aspecto acabado, o que talvez possa ser explicado pelo fato de ser um habitual passado com o pretérito imperfeito que, como já observamos, tende a ser interpretado como acabado. Apenas 18,5\% dos falantes apontou a frase b como tendo aspecto acabado e $18,5 \%$ disse que nenhuma das duas frases tinha aspecto acabado.
} 
396. Sérgio escrevia bem. (Frase II.4.a do questionário).

397. Sílvio estudava muito. (Frase III.4.a do questionário).

398. Pedro lutava bem. (Frase VIII.1.a do questionário).

399. Fábio emoldurava quadros. (Frase VIII.3.a do questionário).

Na língua falada, a exemplo do que acontece com os verbos de estado, também o pretérito imperfeito dos verbos atélicos marca o aspecto acabado, quando enfatizado dentro da frase, pela entonação.

Quando apresentamos frases com verbos télicos no pretérito imperfeito e enfatizados, os falantes estranharam, não vendo razão para a ênfase que lhes parecia deslocada e gratuita ou então acharam que se queria deixar claro que alguém fazia uma determinada coisa e não outra. Assim, por exemplo, diante da frase (400).

400. João lia o livro. (Com o verbo enfatizado)

os falantes tinham duas reações: ou achavam que a ênfase era desnecessária, sem razão de ser ou que estávamos queremos deixar claro que o que João fazia com o livro era lê-lo e não outra coisa. Isto nos leva a concluir que esse processo não altera o papel do pretérito imperfeito quanto à expressão dos aspectos acabado e não acabado, quando o verbo é télico.

É preciso anotar ainda que, se na frase com verbo atélico no pretérito perfeito houver um adjunto adverbial que indica o momento de término da situação ou a sua duração total (este transforma o verbo em télico), teremos o aspecto acabado. Veja exemplos (401) e (402).

401. O conferencista falou até às vinte e duas horas.

402. Osvaldo tocou durante uma hora.

4) Quando temos na frase um adjunto adverbial de frequência, como nas frases do tipo de (383), especialmente se representado pelo advérbio sempre, o aspecto acabado é marcado pelo pretérito imperfeito, tanto na situação "em contraste", quanto na situação "sem contraste". (cf. porcentagens no quadro V, itens III.3 e III.4). Aqui não importa se o verbo é télico ou atélico. É interessante notar que com o pretérito perfeito a ideia de não acabado se mantém apesar da tendência para interpretar o habitual passado como acabado.

5) Confrontando o pretérito imperfeito simples com o pretérito imperfeito com adjunto adverbial de frequência, pudemos constatar que, para os verbos atéli- 
cos, nenhuma dessas formas foi apontada como marcando mais o aspecto acabado que a outra (cf. porcentagens no item III.5 do quadro V), embora tenha havido uma ligeira predominância do pretérito imperfeito simples.

As porcentagens obtidas para as duas formas separadamente parecem enfraquecer a colocação feita na conclusão 3 acima de que o pretérito imperfeito tende a marcar o aspecto acabado com os verbos atélicos. Todavia isto não ocorre porque não estamos vendo a expressão do acabado por dois tempos diferentes, mas pelo mesmo tempo em dois usos diferentes e, assim sendo, o que temos é que para $73 \%$ dos falantes consultados o pretérito imperfeito marca aspecto acabado com os verbos atélicos, enquanto para $27 \%$ este tempo não marca o acabado com tais verbos. Vemos, então, que os resultados abordados aqui na verdade reforçam o que se colocou na conclusão de número 3 .

Para os verbos télicos vemos que o resultado acima se mantém: nenhuma das formas foi apontada como marcando mais o aspecto acabado que a outra (cf. porcentagens no item III.5 do quadro V), embora tenha havido uma certa predominância do pretérito imperfeito com adjunto adverbial de frequência. Para $13,5 \%$ dos falantes nenhuma das formas marca o acabado com verbos télicos.

Juntando as porcentagens obtidas para as duas formas com verbos télicos, temos que, para $86,5 \%$ dos falantes consultados, o pretérito imperfeito marca o aspecto acabado com verbos télicos. Isto invalidaria a conclusão de número 2 acima em que verificamos que com verbos télicos é o pretérito perfeito e não o pretérito imperfeito que marca o acabado. Entretanto essa invalidação não acontece porque se observamos as frases X.2 a 4 e XI.2 a 4 do questionário no apêndice I, verificaremos que todas elas têm sentido habitual e naturalmente passado. Ora, considerando que ali não temos a frase com o pretérito perfeito e que se solicitou ao falante que assinalasse qual das duas frases apresentava a situação como acabada, a tendência existente para considerar o habitual passado como acabado passou a funcionar praticamente sem restrição, surgindo daí a porcentagem de $86,5 \%$ que, entretanto, não pode ser considerada para invalidar o que se disse na conclusão 2 , pois não diz respeito à ação do pretérito imperfeito na expressão do aspecto acabado.

De tudo o que dissemos aqui a única conclusão possível é que as duas formas em estudo (pretérito imperfeito simples e com adjunto adverbial de frequência) parecem ter, para os falantes, ação mais ou menos idêntica na expressão do aspecto acabado.

6) Confrontando o pretérito imperfeito simples com o pretérito imperfeito presentificado vimos que, para os verbos atélicos, os dois têm o mesmo valor com relação à expressão do aspecto acabado (cf. porcentagens em III.6 no quadro V). Isto vai contra a previsão que fizemos de que o pretérito imperfeito do indicativo, 
quando presentificado a outra situação também passada, tem os aspectos imperfectivo, cursivo e não acabado, já que o cursivo e o acabado não aparecem juntos para a mesma situação.

Como 43,5\% dos falantes que responderam o questionário disseram que o pretérito imperfeito presentificado a outra situação passada tinha aspecto acabado, procuramos saber o porquê. Verificamos que nas frases:

403. a - Maria estudava muito quando a conheci. (Frase IV.4.b do questionário)

b - Paulo falava de você quando entrei na sala. (Frase VII.2.b do questionário)

c - Celso podava plantas quando ouviu o estouro. (Frase VIII.5.b do questionário)

usadas no questionário, a situação presentificadora, expressa pela oração temporal foi tomada pelos falantes como uma espécie de limite no passado para a situação expressa na principal que então não está em realização no momento em que se fala. Vemos, portanto, que o resultado aqui não invalida a previsão feita, pois o falante não considerou a situação expressa na oração principal como presente e em curso em relação ao momento de ocorrência da situação expressa na temporal, o que não se pode negar que seja verdade; mas considerou-a em relação ao momento em que se fala ${ }^{16}$, havendo pois influência da suposição falsa de que o que é passado também é acabado. Mas mesmo neste caso vemos que não se pode inferir da frase o acabado para a situação da principal, porque nas frases de (403) não há a implicação de que Maria não mais estuda muito no momento em que se fala, ou que Celso não mais está podando plantas; além disso, é bem claro que as situações de estudar, falar e podar são não acabadas no momento de ocorrência das situações de conhecer, entrar na sala e ouvir o estouro.

Para apenas 18,5\% dos falantes (cf. item III.6 do quadro V) o pretérito imperfeito não marca aspecto acabado com os verbos atélicos, ou seja, para 81,5\% dos falantes o pretérito imperfeito marca o acabado com os verbos atélicos o que reforça a conclusão de número 3 acima.

\footnotetext{
${ }^{16}$ Para (403b) há inclusive na instrução dada, como se pode verificar, o seguinte trecho: "a situação... que não está mais em realização no momento em que se fala", o que naturalmente foi uma falha do questionário, pois levou o falante a considerar a frase mais em relação ao momento em que se fala. Para (403a), em que a instrução era diferente, a porcentagem obtida foi idêntica à obtida para (403b) $(52 \%)$, provavelmente por influência da frase ser habitual e passado o que normalmente leva a ver a situação também como acabada. Em (403c), onde a frase não era habitual, nem a instrução dada levava a considerar a situação em relação ao momento em que se fala, apenas $27 \%$ dos falantes apontou a frase como tendo aspecto acabado.
} 
Para os verbos télicos o resultado ficou mais de acordo com a previsão feita, já que $47,5 \%$ dos falantes apontou o pretérito imperfeito simples como marcador do acabado, enquanto apenas $27,5 \%$ considerou o pretérito imperfeito presentificado como marcando o acabado. Para $25 \%$ dos falantes nenhuma das formas marca o acabado.

As colocações de 5 e 6 acima têm caráter especulativo e procuram determinar que tipo de frase com o pretérito imperfeito do indicativo, sem confronto com o pretérito perfeito do indicativo, tem aspecto acabado ou é sentida pelos falantes como tendo este aspecto e em que medida. Parece não haver, nos casos ali abordados, nada perfeitamente estabelecido no sistema linguístico do falante (em que pese algumas falhas do questionário por nós apontadas), mas fica clara a tendência que os falantes têm para interpretar o que é passado como acabado, pois como se pode ver no quadro V (itens III.5 e III.6) apenas para uma média de $22,7 \%$ dos falantes com os verbos atélicos e para uma média de 19,3\% com os verbos télicos o pretérito imperfeito do indicativo não marcava o acabado nem sozinho, nem com presentificador, nem com o adjunto adverbial de frequência. Observa-se também a ação da tendência para interpretar o habitual passado como acabado.

O que ficou colocado nas conclusões 3 e 4 e parte dos comentários de 5 e 6 acima são argumentos a favor da colocação de que o aspecto perfectivo não é caracterizado por apresentar a situação como acabada, mas sim como completa. Vimos casos em que formas imperfectivas têm também aspecto acabado e em 4 vimos que uma forma perfectiva pode ter aspecto não acabado, embora o mais comum seja a forma perfectiva ter também aspecto acabado o que levou muitos a caracterizarem o aspecto perfectivo como acabado, talvez erroneamente.

Naturalmente pode haver entre as frases outras diferenças semânticas além das aspectuais. Assim, por exemplo, nas frases do tipo de (404) abaixo, que levaram à conclusão de número 4 acima, vemos que com o verbo no pretérito imperfeito há referência a um passado habitual sem um limite expresso, enquanto que com o pretérito perfeito há referência a um passado habitual, especificando-se um tempo que tem um limite: o momento em que se fala (isto teria de ser assim em consequência da presença do perfectivo que exige um período de tempo completo e portanto perfeitamente limitado). Outra diferença no mesmo tipo de frase é que com o pretérito perfeito se enfatiza o completamento de cada realização da situação habitual e com o pretérito imperfeito isso não se dá (esta diferença já é devida à oposição perfectivo/imperfectivo). 
404. a - Ele sempre falava comigo.

b - Ele sempre falou comigo.

O pretérito imperfeito do indicativo não atualiza nenhum aspecto nos seguintes casos:

a. quando é empregado pelo futuro do pretérito, normalmente para expressar uma situação que seria consequência certa de outra que não ocorreu. É o que temos nos exemplos (405) e (406) abaixo.

405. "O patrão é porque não tem força. Tivesse ele os meios e isto virava um fazendão." (Monteiro Lobato) ${ }^{17}$

406. Se eu fosse ao cinema, levava você.

b) quando é empregado pelo presente do indicativo, como forma de polidez. É o chamado imperfeito de cortesia. Veja exemplos (407) a (409).

407. O senhor segurava este embrulho para mim enquanto telefono?

408. Você me emprestava seu paletó?

409. Sr. Manuel, eu desejava telefonar. ${ }^{18}$

Neste caso a expressão do aspecto às vezes não se anula de todo, mas a noção aspectual fica bastante enfraquecida, praticamente inexistente. É o que acontece, por exemplo, na frase (409). Em exemplos como (407) e (408) há um valor de futuro tal como o que referimos para os exemplos (341) a (343).

Podemos observar que entre o presente do indicativo e o pretérito imperfeito há um paralelismo aspectual bastante acentuado. Basta para isso comparar o que dissemos sobre a expressão do aspecto por esses dois tempos flexionais. Essa grande semelhança do pretérito imperfeito do indicativo com o presente do indicativo, no que diz respeito à expressão do aspecto, é explicada pelo fato de que o pretérito imperfeito é um "presente do passado", tanto assim que, ao falar de seu emprego, diz-se que é o tempo que usamos "quando, pelo pensamento, nos transportamos a uma época passada e descrevemos o que então era presente" (CUNHA, 1975, p.432). ${ }^{19}$

\footnotetext{
${ }^{17}$ Exemplo (405) apud Cunha (1975, p.433).

${ }^{18}$ O Exemplo (409) é de Bechara, (1977, p.274).

${ }^{19}$ Bechara, (1977, p.274) faz a mesma colocação com praticamente as mesmas palavras.
} 


\section{4 - Pretérito Mais-QUe-PeRfeito do indicativo}

O pretérito mais-que-perfeito do indicativo atua de forma idêntica ao pretérito perfeito na expressão do aspecto, exceto pelo fato de que o pretérito mais-que-perfeito sempre marca o aspecto acabado. A colocação no pretérito mais-que-perfeito das frases com que exemplificamos a questão do aspecto do pretérito perfeito mostra ser verdade o que afirmamos.

Os únicos aspectos que o pretérito mais-que-perfeito marca em si são o perfectivo e o acabado. Frases com este tempo só terão outros aspectos por influência de adjuntos adverbiais, do semantema verbal e da repetição do verbo exatamente como acontece com o pretérito perfeito.

Vejamos alguns exemplos de frases com o pretérito mais-que-perfeito e os aspectos nelas presentes:

410. Rafael comera todo o doce. (perfectivo, acabado)

411. Ele correra durante uma hora e estava cansado. (perfectivo, acabado, durativo) - $\mathrm{O}$ aspecto durativo surge por influência do adjunto adverbial "durante uma hora".

412. O rádio estivera estragado e não ouvi o repórter. (perfectivo, acabado, durativo) - O durativo aparece por se tratar de um verbo de estado.

413. Arnaldo lera, lera mas não encontrara o que precisava. (perfectivo, acabado, durativo) - $O$ durativo é marcado pela repetição do verbo.

414. Um pensamento cruzara o meu espírito. (perfectivo, acabado, pontual) - O pontual aparece por se tratar de um verbo de evento.

415. Seu filho viera várias vezes aqui, mas não me disse nada. (perfectivo, acabado, iterativo) - O iterativo é marcado pelo adjunto adverbial.

416. Silas sempre o protegera, mas um dia não foi possível fazer nada. (perfectivo, acabado, habitual) - O habitual é marcado pelo adjunto adverbial.

Como se sabe, o pretérito mais-que-perfeito é pouco usado, sendo normalmente substituído pela perífrase TER + PARTICÍPIO com o verbo ter no pretérito imperfeito, forma chamada de pretérito mais-que-perfeito composto. Essa forma perifrástica tem o mesmo valor aspectual que o pretérito mais-que-perfeito simples, como veremos no estudo da expressão do aspecto pelas perífrases.

O pretérito mais-que-perfeito não marca aspecto quando, na linguagem literária, é utilizado em lugar do futuro do pretérito ou do pretérito imperfeito do subjuntivo. Veja exemplos (417) a (422). 
417. Que fizera (= faria) você tivera (= tivesse) só mais um dia de vida?

418. Sérgio passou a andar olhando para cima como se vira algo no céu.

Estes exemplos, entretanto, não são comuns. Abaixo registramos alguns retirados de obras literárias.

419. "Mais servira (= serviria), se não fora (= fosse) para tão longo amor tão curta a vida". (Camões)

420. "Que fora (= seria) a vida, se nela não houvera (= houvesse) lágrimas?" (Alexandre Herculano)

421. "Sem Tabira dos Lusos que fora?” (= seria) (Gonçalves Dias)

422. "Daí por diante, Cipriano, a pretexto disto, ou daquilo, proferia exclamações, soltava meias frases, como se falara (= falasse) consigo mesmo, pois não se voltava para s'Aninha”. (Afonso Arinos $)^{20}$

\section{5 - FUTURO DO PRESENTE E FUTURO DO PRETÉRITO}

O futuro do presente e o futuro do pretérito em si não marcam qualquer aspecto. Como já dissemos, há referência apenas à situação sem atualização da categoria de aspecto (cf. no item 2.2.2 o comentário feito para o exemplo 61). Podemos observar a ausência do aspecto nos futuros do presente e do pretérito nos exemplos (423) a (429).

423. Plantaremos muitas árvores no quintal.

424. Geraldo pintará um quadro para mim.

425. Eu serraria as tábuas para você, se tivesse um serrote.

426. Em 1950 mudamos para São Paulo. Rogério morreria dois anos depois.

427. Morrerei de tristeza, se você for embora.

428. Zarparíamos ao amanhecer, se o tempo tivesse melhorado.

429. Comendo assim, você engordará.

${ }^{20}$ Exemplos (419) e (420) apud Bechara (1977, p.275). Exemplos (421) e (422) apud Cunha (1975, p.437). 
As razões pelas quais estes dois tempos flexionais, em si, não indicam aspecto parecem vir de duas fontes diferentes:

a. em primeiro lugar, eles marcam o tempo futuro que atribui à situação uma realização virtual, até certo ponto abstrata, que enfraquece as noções aspectuais que estão sendo atualizadas, dificultando a percepção das mesmas, ou as anula;

b. em segundo lugar, estes tempos têm um valor modal, proveniente de seu valor de futuro, que restringe a expressão do aspecto. (cf. item 10.3: relação entre modo e aspecto).

Sobre as razões pelas quais as formas de sentido futuro normalmente não marcam aspecto, falamos mais detalhadamente em 10.2, onde estudamos a relação entre o tempo e o aspecto.

Também quando usado pelo imperativo, o futuro do presente não expressa aspecto, evidentemente pelo valor modal que apresenta também neste caso. Veja exemplos (430) a (432).

\section{Não matarás.}

431. Você esperará por mim aqui.

432. Luiz, você seguirá comigo.

É preciso ficar claro que não estamos dizendo que não há expressão de aspecto no futuro, quando o tempo flexional é o futuro do presente ou o futuro do pretérito, mas sim que estes tempos em si não marcam nenhum aspecto. A interferência de outros recursos nos dará aspectos com estes dois tempos. Veja, por exemplo, os aspectos presentes nas frases (433) a (449), graças à ação das perífrases verbais e adjuntos adverbiais.

433. Quando você voltar, terei escrito a carta. (perfectivo e acabado).

434. Às quatorze horas estarei conversando com os professores. (imperfectivo, não acabado, cursivo, durativo).

435. Começaremos a sortear os prêmios às vinte e duas horas, quando todos estiverem cansados de dançar. (inceptivo).

436. Elizete ficará orientando os alunos das oito às doze horas e você das quatorze às dezesseis horas. (durativo).

437. A comida irá esquentando, enquanto você toma banho. (durativo).

438. Eu teria lido o livro se eu o tivesse encontrado. (perfectivo, acabado). 
439. Mirtes estaria morando conosco se vocês não fossem tão incompreensivos. (imperfectivo, não acabado, cursivo, durativo).

440. Eu começaria a trabalhar amanhã se estivesse bom. (inceptivo).

441. Você continuará falando quando começarmos a distribuir os papéis. (começado).

442. Francisco andará faltando às aulas? (imperfectivo, iterativo, não acabado) (Aqui há um valor hipotético).

443. Eles não viverão mentindo para nós? (imperfectivo, não acabado, habitual).

É interessante observar que, em frases como (438) e (439), o futuro do pretérito perde a noção de futuro e fica apenas com a função de introduzir a noção modal de possibilidade (hipótese) em uma situação passada hipotética (exemplo 438), ou em uma situação presente hipotética (exemplo 439).

Nos exemplos (444) a (449) o aspecto se deve aos elementos adverbiais em negrito (adjuntos ou orações).

444. Você irá ao curral todos os dias, para ver os bezerrinhos. (habitual)

445. Aos domingos passearemos pelos campos. (habitual)

446. Eles atravessarão o rio várias vezes. (iterativo)

447. Quando você voltar aqui, já não terei mais este quadro de Picasso. (acabado)

448. Você ouvirá falar de mim muitas vezes. (iterativo)

449. Antônio me disse que ficaria aqui, enquanto tudo não ficasse esclarecido. (durativo)

Observe-se que em (447) a situação que tem aspecto acabado (ter) é anterior (passada) em relação à outra situação (voltar). Temos um passado relativo (Cf. nota 152 ). 


\section{6 - O IMPERATIVO}

As flexões verbais do imperativo ${ }^{21}$ marcam, essencialmente, modalidade. No que diz respeito ao tempo, "o imperativo é enunciado no tempo presente, mas na realidade este "presente do imperativo" tem valor de um futuro, pois a ação que exprime está por realizar-se" (CUNHA, 1975, p.453).

Devido à sua função básica de marcar modalidade e também pelo seu valor futuro, as flexões do imperativo não marcam aspecto, porque, normalmente, a modalidade bem como o futuro restringem a atualização do aspecto (cf. itens 10.2 e 10.3). Nos exemplos (63) e (450) a (456), podemos observar que as flexões do imperativo não marcam aspecto.

450. Atirem nos pneus, para que elas tenham de parar!

451. Sai daqui, sujeito nojento!

452. Dê-me o bisturi.

453. Não façais a outrem o que não quereis que vos façam.

454. Diga-lhe que não quer mais vê-lo.

455. Falemos de coisas mais agradáveis.

456. Comamos em silêncio.

Embora a marcação de modalidade no imperativo seja bastante acentuada, restringindo a atualização do aspecto, este pode aparecer, como nos exemplos (457) e (458) abaixo, por influência de outros recursos de expressão.

457. Esteja trabalhando quando eu chegar aí ou você verá uma coisa! (imperfectivo, não acabado, cursivo, durativo) (aspecto marcado pela perífrase).

458. Esteja terminando de fazer os deveres, quando eu chegar à tarde, para que possamos sair à noite. (imperfectivo, não acabado, terminativo) (aspecto marcado por uma combinação de perífrases).

\footnotetext{
${ }^{21}$ Estamos considerando as formas do imperativo negativo, e as formas da $3^{\text {a }}$ pessoa do singular e das $1^{\mathrm{a}}$ e $3^{\mathrm{a}}$ pessoas do plural do imperativo afirmativo, como formas do imperativo e não como formas do subjuntivo com função de imperativo, por não vermos na coincidência formal uma razão suficiente para considerar como do subjuntivo, formas do imperativo. Cunha (1975), Bechara (1977) e Said Ali (1964) ao falar do emprego do subjuntivo, aí incluem tais formas do imperativo. O que expomos aqui não será afetado pela adoção de uma ou outra posição.
} 
Pode-se ver, no capítulo 1, que nenhum estudo sobre o Português se refere direta ou indiretamente ao aspecto no imperativo. Também não encontramos nada sobre a questão em autores que estudaram o aspecto em outras línguas.

\section{7 - Tempos FLeXIONAIS Do SUbJUNTIVO}

Uma vez que o aspecto é uma categoria objetiva, indubitavelmente aflora com maior clareza nos tempos do indicativo, que exprimem situações objetivas, já que as apresentam como certas e reais. Já nos tempos do subjuntivo, a atualização do aspecto rareia, pois aí as situações são apresentadas como irreais, incertas, duvidosas. A atribuição à situação de uma realização duvidosa, hipotética e, portanto, até certo ponto abstrata, enfraquece as noções aspectuais que estão sendo atualizadas, dificultando a percepção das mesmas ou anulando-as completamente.

Além disso, como é bem sabido, as flexões temporais do subjuntivo normalmente aparecem para indicar modalidade ou sujeitas a elementos marcadores de modalidade e, como veremos no item 10.3, certas modalidades restringem a expressão do aspecto.

Que o aspecto normalmente não se atualiza, quando temos tempos do subjuntivo, é indubitável. Consequência e evidência disso é o fato de nenhum estudioso do Português ter-se referido, direta ou indiretamente, à presença de qualquer noção aspectual em frases ou orações com tempos do subjuntivo, quando, com tempos do indicativo, tais referências são constantes, mesmo quando o autor não trata diretamente do aspecto (cf. capítulo1). Também não encontramos referências ao aspecto no subjuntivo em autores que estudaram a categoria em outras línguas.

Se observarmos os diferentes casos de uso do subjuntivo registrados nas gramáticas do Português, veremos que, em um bom número deles, o aparecimento do subjuntivo está condicionado à expressão de uma modalidade e aí o aspecto normalmente não aparece. Vejamos alguns destes casos. ${ }^{22}$

O subjuntivo aparece em orações independentes ${ }^{23}$ nos seguintes casos:

\footnotetext{
${ }^{22}$ Os casos que aqui enumeramos foram retirados de Bechara (1977, p.276-279), Cunha (1975, p.442447) e Said Ali (1964, p.166-172).

${ }^{23}$ Azevedo (1976) apresenta evidências de que, em verdade, não há subjuntivo independente. A discussão desse problema foge ao escopo deste estudo. (AZEVEDO, M. M. O subjuntivo em português. Petrópolis: Vozes, 1976. 56 p.).
} 
a. nas orações optativas que exprimem um desejo, um anelo (modalidade de volição). ${ }^{24}$ Exemplos:

459. Deus lhe dê tudo de bom!

460. Oxalá meu filho consiga um bom trabalho!

461. Diabos o levem, João!

462. Que nós tenhamos coragem suficiente!

463. Tomara que ele traga muitas novidades!

464. "Que eu não sinta o coração" - Fernando Pessoa ${ }^{25}$

b. nas orações dubitativas, geralmente com o advérbio talvez. (modalidade de probabilidade ou possibilidade). Exemplos:

465. Talvez o bebê nasça ainda hoje.

466. Talvez José me emprestasse um terno, mas eu não quis pedir.

467. Talvez ele venha de carro.

Observe que nos exemplos (459) a (467) o subjuntivo tem o valor de futuro, o que também contribui para a não atualização do aspecto.

Se, porém, as frases dubitativas com "talvez" tiverem interpretação de presente, como normalmente acontece quando temos verbos estáticos, teremos aspecto atualizado, a despeito da modalidade de possibilidade ou probabilidade presente. Veja exemplos (468) a (471).

468. Talvez José seja bondoso e não mau como todos pensam. (imperfectivo, indeterminado).

469. Talvez ele não estivesse no escritório, quando você ligou. (imperfectivo, não acabado, cursivo).

470. Talvez ele possua muito dinheiro e pretenda ajudar o próximo. (imperfectivo, não acabado, cursivo, durativo).

471. Talvez Raquel saiba onde mamãe está. (imperfectivo, não acabado, cursivo, durativo).

\footnotetext{
${ }^{24}$ No item 10.3, ao falarmos da relação entre modo e aspecto, definimos modalidade e apresentamos uma lista de modalidades básicas, em que se pode englobar quase todas as modalidades que habitualmente são citadas.

${ }^{25}$ Exemplo (464) apud Cunha (1975, p.444).
} 
O fato da situação ser apresentada como hipotética dificulta um pouco a percepção do aspecto.

No estudo do aspecto expresso no subjuntivo, poderemos observar que, muito frequentemente, os verbos estáticos terão o efeito que apresentam nas frases dubitativas.

O subjuntivo normalmente aparece em orações subordinadas nos seguintes casos: ${ }^{26}$

1) Com orações subordinadas substantivas, depois de expressões (verbos, nomes ou locuções formadas de verbo + adjetivo ou substantivo) que denotam:

a. vontade em todos os seus matizes (modalidade de volição). Exemplos:

472. Quero que você se divirta bastante.

473. Peço aos céus que nada de mal te aconteça.

474. Antônio desejava que você morasse com ele.

475. Espero que atendas o meu pedido.

Na principal, ainda podem aparecer verbos como rogar, suplicar, implorar;

b. ordem (prescrição ordenativa positiva), proibição (prescrição ordenativa negativa) ou prescrição aconselhativa. Exemplos:

476. O feitor ordenou que levássemos os dormentes.

477. Papai manda que esperemos aqui.

478. O regulamento proíbe que fiquemos no corredor.

479. O síndico proibiu que se usasse o elevador social para transportar bagagem.

480. $\quad$ O médico recomendou que não se fizesse barulho.

481. O rapaz aconselhou que não manifestassem descontentamento.

c. necessidade (modalidade de necessidade). Exemplos:

482. Cumpre que voltemos.

483. É necessário que compremos uma bomba para o poço.

484. Importa que sejais mais educados.

485. Seria bom que todos assinassem a petição.

\footnotetext{
${ }^{26}$ Subentende-se em todos os casos que a situação é apresentada como irreal, incerta, duvidosa. As gramáticas comumente registram que, em muitos destes casos, se a situação for tida como certa e real pelo falante, o indicativo aparece ou pode aparecer.
} 
Na principal ainda podem aparecer convir, ser preciso, ser conveniente, etc.;

d. possibilidade e probabilidade que podem aparecer sob diferentes ângulos. Exemplos:

486. Presumi que ele fizesse algo de ruim para se vingar.

487. É possível que Marcos nos dê notícias de Marli.

488. $\quad$ É provável que ele lute esta noite.

489. Papai permitiu que fôssemos ao baile. (deu a possibilidade, a permissão)

490. Ricardo admitiu que você corra para representar o clube. (reconhecer a possibilidade)

491. Sua condição impede que eu o expulse daqui. (tirar a possibilidade)

492. Nada obstava que ele realizasse seu sonho. (tirar a possibilidade)

493. Tenho receio que meu filho se machuque. (ter medo da possibilidade)

494. Célia temia que o pai morresse. (idem a 493)

495. Eu duvidava que ele fosse ao baile. (não crer na possibilidade)

e. um sentimento, uma apreciação subjetiva sobre a situação de que se fala, ou a dúvida de um modo geral que se tem sobre a realidade.

496. É justo que ele receba o prêmio.

497. Alegra-me que você venha.

498. Seria incrível se o menino ganhasse a partida de xadrez.

2) Com orações subordinadas adjetivas que denotam:

a. um fim que se pretende alcançar. Exemplo:

499. Espero uma oportunidade que me permita mostrar meu talento.

b. um fato improvável (caso frequente quando a principal é negativa, interrogativa ou restritiva). Exemplos:

500. Encontraste alguém que substituísse a antiga secretária?

501. Não houve ninguém que aceitasse a incumbência. 
c. uma conjectura, uma hipótese e não uma realidade.

502. Se te oferecerem um emprego que te convenha deves aceitá-lo.

503. O cidadão que ame sua pátria, engrandece-a. ${ }^{27}$

3) Com orações subordinadas adverbiais:

a. concessivas, normalmente iniciadas por embora, mesmo que, ainda que, conquanto, posto que, se bem que, por muito que, por pouco que. Segundo Bechara (1977) não há completo rigor a respeito do uso do subjuntivo neste caso.

504. Mesmo que ele me desse outro vestido, não perdoaria sua brutalidade.

505. Ainda que ele me proíba, eu não deixarei de estudar.

506. Por muito que você pratique, não será um malabarista como Élio.

É importante observar que nas coordenadas alternativas de sentido concessivo também se usa o subjuntivo. Exemplos:

507. Quer chova, quer faça sol, realizaremos a festa.

508. Seríamos punidos quer ganhássemos, quer perdêssemos o jogo.

Podemos ter frases desse tipo com ou $[\ldots]$ ou, mas são pouco usadas.

b. condicionais, em que a condição é hipotética. Estas orações normalmente são iniciadas por se, contanto que, sem que, a não ser que, suposto que, caso, dado que.

509. Caso ele compre o carro, receberás uma comissão.

510. Se José se afogar, serás o culpado.

511. Sem que o doente consinta, nada podemos fazer.

512. Se eles viessem, teríamos uma festa animadíssima.

513. Se o diretor atendesse nosso pedido, todos seriam beneficiados.

c. consecutivas, quando expressam uma concepção, um fim a que se pretende ou pretenderia chegar e não uma realidade. Exemplos:

${ }^{27}$ O exemplo (502) é de Cunha (1975, p.445), e o exemplo (503) é de Bechara (1977, p.277). 
514. Queria estudar para saber tanto que ninguém soubesse mais que ele.

515. Tente agir de maneira tal que ninguém perceba.

516. Procede de tal modo, que não dês lugar à censura.

517. Queria aparecer com figura tão sombria, que causasse medo a todos. $^{28}$

d. finais, normalmente iniciadas com para que, a fim de que. Exemplos:

518. O rapaz fez-me sinal que fosse até o balcão.

519. Às vezes Deus deixa os vaidosos subirem bem alto em seu orgulho para que sintam a dor de uma queda maior.

520. O preso gritava para que o soltassem.

e. temporais que marcam a anterioridade, normalmente iniciadas por antes que, assim que, até que, enquanto, depois que, logo que. Essas temporais têm subjuntivo quando indicam uma simples concepção e não uma realidade. Exemplos:

521. Prometi que ficaria aqui enquanto você não sarasse.

522. Avisaremos assim que ele saia daqui.

523. Previna seu tio, antes que o roubem.

524. Eu lhe comprarei o vestido, depois que receber.

525. Você deveria deixar o amendoim ao sol até que secasse.

O futuro do subjuntivo aparece, normalmente, em orações subordinadas adverbiais condicionais, temporais e conformativas. A principal, neste caso, tem o verbo no futuro do presente ou no presente do indicativo com valor futuro. Vejamos alguns exemplos já que foram poucos os que apareceram até agora.

526. Se ele trouxer a encomenda hoje, dar-lhe-ei uma gorjeta.

527. Quando seu irmão chegar avise-me.

528. Quando dermos uma festa eu o convidarei.

529. Se as reses escapulirem do curral, teremos um trabalho enorme para recolhê-las.

530. Enquanto não vir essa peça, não sossegarei.

531. Quando eu terminar este trabalho, tirarei férias.

${ }^{28}$ Os exemplos (516) e (517) são de Said Ali (1964, p.171). 
532. a - Se a encomenda chegar, levarei para você.

b - Se a encomenda chegar, levo para você amanhã.

533. Agirei conforme a assembleia decidir.

534. Fica combinado que receberás, conforme trabalhares.

Às vezes, o futuro do subjuntivo aparece em orações adjetivas. Veja exemplos (535) e (536):

535. Só poderão entrar os que apresentarem credenciais.

536. Não decepciones aos que te apoiarem neste momento.

Expusemos acima os principais casos de uso do subjuntivo. Naturalmente não fomos exaustivos, já que nosso objetivo é estudar a questão do aspecto e não o emprego do subjuntivo.

Como se pode observar, nos exemplos de números (459) a (467) e (472) a (536), todos com os verbos em tempos de subjuntivo, o aspecto não é atualizado. Esta não atualização do aspecto se deve, em primeiro lugar, ao fato do subjuntivo apresentar a situação como duvidosa, hipotética, incerta, o que lhe dá sempre um valor modal. Além dessa modalidade de possibilidade, e não de certeza, podemos ter outras modalidades, como vimos acima, ao falar dos casos em que normalmente o subjuntivo é usado. A presença de algumas modalidades, já o dissemos, restringe a atualização do aspecto, enfraquecendo as noções aspectuais (o que dificulta a sua percepção) ou anulando-as. Em segundo lugar observamos que, nos exemplos (459) a (467) e (472) a (536), o subjuntivo tem normalmente um valor futuro. Já falamos no item 7.5, e ainda comentaremos no item 10.2 (relação entre tempo e aspecto), que o tempo futuro restringe a expressão do aspecto. Portanto, nestes casos, a não atualização do aspecto parece dever-se à influência não só da modalidade contida no subjuntivo ou à qual ele se deve, mas também do futuro.

$\mathrm{Na}$ verdade, esse valor futuro parece ser vital para a não atualização do aspecto, pois, como vimos para as frases dubitativas com "talvez", se o subjuntivo tiver um valor de presente o aspecto se atualiza (cf. o que dissemos para os exemplos 468 a 471). Isto se verifica não só para as frases dubitativas. Podemos observar que, se o subjuntivo tiver valor de presente ou de passado, normalmente o aspecto se atualiza.

Antes de apresentarmos exemplificação que evidencia o que afirmamos no parágrafo anterior, queremos lembrar o que Cunha (1975, p.448-449) afirma. 
Citando Moignet ${ }^{29}$, ele diz que os tempos do subjuntivo (= tempos flexionais) não representam noções de época (= tempo) da forma como os do indicativo o fazem; mas que se pode falar de certos hábitos de concordância dos tempos, que não procedem de automatismos rígidos e puramente formais, mas que antes resultam do funcionamento de mecanismos delicados e complexos. A seguir apresenta os principais valores dos tempos do subjuntivo, dizendo que o presente pode apresentar a situação como presente ou futura, que o pretérito imperfeito pode apresentar a situação como passada, presente ou futura e que o futuro a apresenta apenas como futura. Assim sendo, parece que temos possibilidade de atualização do aspecto apenas com o presente e o pretérito imperfeito do subjuntivo.

Vejamos agora uma série de exemplos com o verbo no subjuntivo, tendo valor de presente ou passado, em que o aspecto se atualiza. Deve-se observar que a apresentação da situação como hipotética deixa a noção aspectual menos clara. Note-se também que, quando o verbo é um verbo estático, principalmente de estado, a noção aspectual é percebida com maior clareza. Indicamos, entre parênteses, o aspecto atualizado e o valor temporal do tempo flexional do subjuntivo.

Em orações subordinadas substantivas:

537. Espero que ele tenha boa educação. (presente) (imperfectivo, não acabado, cursivo, durativo).

538. Não bastava que esse homem possuísse poder sobre nós? Era preciso lhe darem poder também sobre os nossos? (passado) (imperfectivo, não acabado, cursivo, durativo).

539. Presumo que eles gostem de samba. (presente) (imperfectivo, não acabado, indeterminado).

540. Imagino que vocês estejam cansados. (presente) (imperfectivo, não acabado, cursivo, durativo).

541. Entendo que eles pensassem assim, quando eram jovens, mas agora. (passado) (imperfectivo, não acabado, cursivo, durativo).

542. Muito me admira que você sonegue imposto! (presente) (imperfectivo, não acabado, habitual).

543. Nada impede que seu pai esteja vivo. (presente) (imperfectivo, não acabado, cursivo, durativo).

544. Eu receava que ele comprasse aqueles objetos de ladrões. (passado) (imperfectivo, não acabado, habitual).

${ }^{29}$ MOIGNET, G. Essai sur le mode subjonctif en latin post: classique et en ancien français. Paris: Alger, 1959. p.131. 
545. É Eossível que ele seja daltônico. (presente) (imperfectivo, não acabado, indeterminado).

Neste exemplo (545), o indeterminado é marcado pelo semantema do verbo ser. Isto ocorre também em outros exemplos em que este verbo aparece.

546. É provável que Bruno saiba de tudo. (presente) (imperfectivo, não acabado, cursivo, durativo).

547. Alegra-me que ganhes muito dinheiro. (presente) (imperfectivo, não acabado, habitual).

548. É É comum que ninguém apareça. (presente) (imperfectivo, não acabado, habitual).

Neste exemplo (548), a habitualidade parece ser devida antes à expressão "é comum" que a outro elemento qualquer.

549. Suspeitávamos que a luz procedesse de algum tipo de material fosforescente. (passado) (imperfectivo, não acabado, cursivo, durativo).

550. Folgo que estejas restabelecido. (presente) (imperfectivo, não acabado, cursivo, durativo).

551. É estranho que estas plantas morram, quando recebem a luz direta do sol. (presente) (imperfectivo, não acabado, habitual).

Neste exemplo (551), a habitualidade aparece por influência da oração temporal "quando recebem a luz direta do sol".

552. Lamento que você dirija tão mal, pois assim não te posso empregar. (presente) (imperfectivo, não acabado, habitual) - O habitual aqui tem a função de caracterizador.

553. Espanta-me que ele faça ginástica todos os dias. (presente) (imperfectivo, não acabado, habitual).

Em orações subordinadas adjetivas:

554. Eu andava à cata de uma empregada que fosse assídua e econômica. (presente) (imperfectivo, não acabado, indeterminado). 
555. Procuro uma empregada que cozinhe bem. (presente) (imperfectivo, não acabado, habitual).

556. A solução é você procurar alguém que empreste dinheiro. (presente) (imperfectivo, não acabado, indeterminado).

557. Não há homem que não tenha medo da morte. (presente) (imperfectivo, não acabado, indeterminado).

558. Há aí alguém que seja completamente feliz? (presente) (imperfectivo, não acabado, indeterminado).

Devido à função adjetiva da oração subordinada adjetiva, temos uma tendência à caracterização dos seres a que a oração se refere. Isso parece levar-nos normalmente aos aspectos indeterminado e habitual, já que são eles que aparecem em frases com a função de caracterizador. É bastante difícil decidir se temos habitual ou indeterminado, pois os habituais que aí aparecem são limítrofes com o indeterminado.

Em orações subordinadas adverbiais concessivas.

559. Os franceses começaram a recuar em 1941. Conquanto retrocedessem, não pensavam perder a guerra. (passado) (imperfectivo, não acabado, cursivo, durativo).

560. Acho Mário meio sem educação, se bem que ele não me trate mal. (presente) (imperfectivo, não acabado, habitual).

561. Embora Edson me amasse, não me respeitava. (passado) (imperfectivo, não acabado, cursivo, durativo).

562. Conquanto o oratório estivesse sujo, vimos que se tratava de uma bela peça. (passado) (imperfectivo, não acabado, cursivo, durativo).

563. Embora ele use roupas caras, não é um homem elegante. (presente) (imperfectivo, não acabado, habitual).

564. Embora José pinte muito bem, não consegue vender muitos quadros. (presente) (imperfectivo, não acabado, habitual).

Em orações subordinadas adverbiais condicionais:

565. Caso Mariana tenha a gramática, traga-a para mim. (presente) (imperfectivo, não acabado, cursivo, durativo).

566. Se seu irmão trabalhasse aqui, nós o conheceríamos. (presente) (imperfectivo, não acabado, cursivo, durativo). 
567. Posto que meus documentos estivessem em ordem, me deixaram embarcar. (passado) (imperfectivo, não acabado, cursivo, durativo).

568. Caso o rapaz venda joias roubadas, prendê-lo-emos hoje mesmo. (presente) (imperfectivo, não acabado, habitual).

569. Tivesses coração, não farias isso. (presente) (imperfectivo, não acabado, cursivo, durativo).

570. Se eu for doente, saberemos logo. (presente) (imperfectivo, não acabado, indeterminado).

571. Se você estiver inocente, isto será provado. (presente) (imperfectivo, não acabado, cursivo, durativo).

Os exemplos (570) e (571) mostram que, embora Cunha (1975, p.450) não tenha apontado, o futuro do subjuntivo pode ter valor de presente.

Em orações subordinadas adverbiais comparativas hipotéticas (normalmente com a conjunção como se):

572. O animal retorcia como se sentisse muita dor. (passado) (imperfectivo, não acabado, cursivo, durativo).

573. O menino mexia-se como se corresse. (passado) (imperfectivo, não acabado, cursivo, durativo).

574. João move os lábios como se falasse algo que eu não ouço. (presente) (imperfectivo, não acabado, cursivo, durativo).

Em orações causais de não porque e não que, quando se quer dizer que a razão aludida não é verdadeira:

575. "Deitei-me ontem mais cedo, não porque tivesse sono, mas porque precisava de me levantar hoje de madrugada". R. de Vasconcelos. ${ }^{30}$ (passado) (imperfectivo, não acabado, cursivo, durativo).

576. Faça bastante comida. Não porque o Vanderlei coma muito, mas porque quero que ele tenha impressão de fartura. (presente) (imperfectivo, não acabado, habitual).

Em orações introduzidas por que, quando restringem a generalidade de uma afirmação:

\footnotetext{
${ }^{30}$ Exemplo (575) apud Bechara (1977, p.278).
} 
577. Não há, que eu saiba, homem mais forte. (presente) (imperfectivo, não acabado, cursivo, durativo).

578. Ocorreram, que se tenha conhecimento, apenas duas aparições deste cometa. (presente) (imperfectivo, não acabado, cursivo, durativo).

Cremos que, apesar das dificuldades já arroladas, fica bastante evidenciado, nos exemplos de números (537) a (578), que as flexões temporais do subjuntivo podem veicular algumas noções aspectuais. Para que isso ocorra, parece que a primeira condição é que o valor temporal de tais flexões seja o presente ou o passado.

Podemos observar também que muitas das frases de (537) a (578) apresentam o fato como certo e não duvidoso e hipotético. Isto se verifica em (538), (541), (542), (547), (548), (550), (552), (553), (559) a (564) e (572) a (576). Nas demais frases, a possibilidade e probabilidade hipotéticas são as modalidades que aparecem.

Disso tudo podemos concluir que os tempos flexionais do subjuntivo não expressam aspecto quando temos simultaneamente certas modalidades e valor temporal de futuro.

A certeza é também uma modalidade, já que é um posicionamento subjetivo do falante em face da situação que exprime (cf. o item 10.3: relação entre modo e aspecto). Considerando isso, podemos dizer que os tempos do subjuntivo expressam aspecto, quando temos as modalidades de certeza, possibilidade - 2 e ou probabilidade - 2 mais valor temporal de presente ou passado.

É interessante observar que as modalidades de certeza, possibilidade - 2 e probabilidade - 2, sendo as que mais facilmente podem ocorrer com situações cuja realização se dá no presente ou no passado, são justamente as que menos restringem a atualização do aspecto. Por outro lado, as modalidades que mais restringem a atualização do aspecto são exatamente aquelas que dificilmente aparecem com uma situação, cuja realização não seja futura, a saber: a prescrição (ordenativa ou aconselhativa), a obrigação, a necessidade, a volição, a intenção, a possibilidade - 1 e a probabilidade - 1 (cf. item 10.3). Tudo isso nos permite antecipar uma conclusão sobre a relação entre aspecto e modo: ${ }^{31}$ as modalidades que mais restringem a atualização do aspecto são aquelas que pressupõem uma realização futura para a situação. No item 10.3, retomamos esta conclusão para discutir algumas questões que ela suscita.

Voltando ao problema da expressão do aspecto pelas flexões do subjuntivo, é preciso observar que, se o aspecto no subjuntivo depende do valor temporal da forma e se, como diz Cunha (1975, p.448), as noções de época (= tempo) no subjuntivo dependem de certos hábitos de concordância dos tempos; pode-se pensar

${ }^{31}$ Estamos usando o termo "modo" como sinônimo de modalidade. Cf. também a nota 153. 
que o aspecto expresso pelo subjuntivo dependa do tempo do verbo da principal.

Considerem-se os exemplos abaixo (os dados entre parênteses se referem ao verbo no subjuntivo).

579. Embora ele estudasse na PUC, não conhecia Da. Rosa. (passado) (imperfectivo, não acabado, cursivo, durativo).

580. Embora ele estudasse na PUC, não conheceu Da. Rosa. (passado) (perfectivo, acabado).

"Estudasse" seria interpretado como "tivesse estudado" em (580). ${ }^{32}$

581. Se estudasse na PUC, conheceria Da. Rosa.

Em (581) há duas possibilidades:

a. (presente) (imperfectivo, não acabado, cursivo, durativo). Neste caso "conheceria" teria valor de presente hipotético. Parece haver um "realmente" subtendido antes de "estudasse";

b. (futuro) (não aspecto). Neste caso, "conheceria" teria valor de futuro.

582. Embora estude na PUC, não conhece Da. Rosa. (presente) (imperfectivo, não acabado, cursivo, durativo).

583. Embora estude na PUC, não conheceu Da. Rosa. (presente) (imperfectivo, não acabado, cursivo, durativo). Parece que se subentende o termo "ainda" no final da frase.

584. Embora estude na PUC, não conhecerá Da. Rosa. (presente) (imperfectivo, não acabado, cursivo, durativo). A interpretação é de que o conhecimento deveria ocorrer, mas por qualquer razão não ocorrerá.

A observação dos exemplos (579) a (584) e de outras variações nos permite ver que o tempo da forma subjuntiva não depende apenas do tempo da principal, mas sim de uma combinação de elementos que nem sempre é fácil determinar. Se o aspecto expresso pelas flexões do subjuntivo depende do valor

\footnotetext{
${ }^{32}$ Se aceitamos que o pretérito imperfeito do subjuntivo tem em frases como (580) o valor da perífrase ter + particípio com o verbo ter no pretérito imperfeito do subjuntivo: esse será talvez, o único caso em que uma flexão verbal do subjuntivo expressa os aspectos perfectivo e acabado.
} 
temporal dessas, só podemos afirmar que o aspecto, nestes casos, dependerá do tempo da principal, na medida em que esse afeta o valor temporal do subjuntivo. Não nos compete determinar aqui em que medida e de que modo isto se dá. Limitar-nos-emos a repetir que, como disse Cunha (1975, p.448), o valor temporal das flexões do subjuntivo depende de mecanismos delicados e complexos, antes que de automatismos rígidos e puramente formais. Para o nosso estudo do aspecto, é suficiente o reconhecimento do tempo que está atualizado na flexão do subjuntivo.

O tempo do verbo de outra oração pode ainda afetar o aspecto expresso pela flexão do subjuntivo, sem afetar o valor temporal dessa. É o que se observa em (585) e (586).

585. Embora Renato corresse quando eu chegava, eu sabia que ele gostava de mim. (passado) (imperfectivo, não acabado, habitual).

586. Embora vovô corresse quando cheguei, não pude acreditar no que via. (passado) (imperfectivo, não acabado, cursivo, durativo).

Vimos que o uso de pretérito perfeito do indicativo ou de pretérito imperfeito do indicativo na temporal tem o mesmo efeito no aspecto expresso pelo pretérito imperfeito do indicativo.

Cumpre também anotar que a interpretação das frases com subjuntivo é, por vezes, extremamente difícil, e ficamos praticamente incapazes de decidir entre uma ou outra possibilidade. Assim, por exemplo, em (580) tanto podemos ter a interpretação ali anotada (Cf. também nota 124), como ter simplesmente uma referência à situação sem a atualização de qualquer aspecto. Numa frase como (587) abaixo, podemos dizer que temos aspectos imperfectivo, não acabado e cursivo? Ou temos apenas a implicação de que ela "faz dieta", a qual estaria nos levando a ver ali um valor de presente e a dizer que o aspecto está atualizado?

587. Se não fizesse dieta, Lilian engordaria.

Se tirarmos o não da condicional e o colocarmos na principal, desaparece a possibilidade da interpretação com aspecto atualizado (cf. exemplo 588) o que nos mostra, mais uma vez, que o aspecto expresso pelas flexões do subjuntivo depende de muitos fatores e não só da relação entre os tempos flexionais das orações. 
588. Se fizesse dieta, Lilian não engordaria.

Numa frase como (589), consideramos a interpretação de "entregares" = "fores entregando" e dizemos que aí há aspecto durativo, ou dizemos que na forma utilizada não há aspecto, apesar de interpretação acima ser possível em virtude do valor proporcional da oração?

589. Pagar-te-emos à medida que entregares (= fores entregando) os quadros.

Estas questões e muitas outras semelhantes são problemas a serem resolvidos por um estudo que trate apenas da expressão do aspecto pelas flexões do subjuntivo.

Eis o que pudemos observar sobre a expressão do aspecto pelas flexões verbais do subjuntivo em si. Resta dizer que, em frases com os tempos do subjuntivo, podemos ter aspectos marcados por outros recursos tal como as perífrases. Veja exemplos (590) a (597) abaixo.

590. Embora ele esteja explicando com tanto empenho, não estou entendendo nada. (imperfectivo, não acabado, cursivo, durativo).

591. Quando ele tiver consertado meu relógio, avisar-me-á. (perfectivo e acabado).

592. Mamãe me disse que fosse catando o arroz para ela. (durativo).

593. Eu esperava que você continuasse me ajudando (começado).

594. Se ele estivesse trabalhando, nada disso teria acontecido. (imperfectivo, não acabado, cursivo, durativo).

595. Mesmo que ele ande saindo com você, isto não quer dizer nada. (imperfectivo, não acabado, iterativo).

596. Embora ele costumasse xingar todo mundo, não era má pessoa. (imperfectivo, habitual).

597. Admira-me que seu tio esteja começando a falar com você. (imperfectivo, começado, inceptivo).

\section{8 - FORMAS NOMINAIS}

Normalmente se diz que o infinitivo é uma forma aspectualmente neutra por se referir apenas à situação em si. O gerúndio apresentaria a situação como inacabada e cursiva e, segundo alguns, como durativa. (cf. capítulo 1). O particípio marcaria o aspecto acabado, apresentando a situação como concluída (cf. capítulo 1). 
Estes valores, embora inerentemente válidos, nem sempre são perfeitamente claros, quando temos estas formas, pois, por vezes, a significação da frase nos dá valores diferentes destes e até mesmo opostos.

No estudo do aspecto expresso pelas formas nominais, podemos considerá-las, quando empregadas nas perífrases ou quando usadas isoladamente. Como no capítulo 8 tratamos da expressão dos aspectos pelas perífrases e aqui nos interessa ver o aspecto expresso pelas formas nominais em si, neste item trataremos apenas das formas nominais não integrantes de perífrases.

\subsection{1 - INFINITIVO}

O infinitivo é aspectualmente neutro. Apresentando a situação em potência, a situação em si, não atualiza qualquer noção aspectual, quer na forma não flexionada, quer na forma flexionada. Veja exemplos (598) a (610).

598. Viemos aqui para ver os cachorrinhos.

599. É difícil acreditar que ele tenha feito isso.

600. Peço-lhe comprar este livro para mim.

601. Acusavam-no de vender títulos falsos.

602. Seu sonho era viver aqui.

603. Eu tinha vontade de pular de para-quedas.

604. Só te falta uma coisa: seres mais gentil.

605. Foram embora sem se despedir.

606. Pedro nos ensinou lutar judô.

607. Minha filha não saía sem antes me avisar.

608. Prenderam-nos por saírem do quartel sem autorização.

609. Ele devia estar muito preocupado para não conseguir dormir.

610. Estudar era a única coisa que ela desejava.

Como se pode ver nos exemplos de números (598) a (610), o infinitivo em si realmente não marca qualquer noção aspectual.

Num exemplo como (608), em que "saírem" é facilmente interpretável como "terem saído", alguém poderia falar em aspecto acabado. Entretanto não achamos válido fazê-lo, pois podemos dar a "saírem" também uma interpretação habitual (= porque saíam). O que temos, na verdade, é uma referência apenas à situação.

É preciso observar ainda que, quando temos verbos estáticos, principalmente verbos de estado, o infinitivo toma um valor temporal de presente, a não ser que algum elemento na frase corte esta possibilidade, e então apresenta-se com aspecto 
atualizado, normalmente imperfectivo, não acabado, cursivo e durativo. Veja os exemplos de números (611) a (614).

611. Sr. Manuel, estão aí alguns homens que querem lhe falar e dizem ter pressa. (imperfectivo, não acabado, cursivo, durativo).

612. Patrícia não foi ao baile por se achar doente. (imperfectivo, não acabado, cursivo, durativo).

613. Comprarei estes cavalos visto serem de boa raça. (imperfectivo, não acabado, indeterminado).

614. É possível eles saberem de tudo? (imperfectivo, não acabado, cursivo, durativo).

\subsection{2 - GERÚNDIO}

Como já dissemos, o gerúndio normalmente é apontado como marcador dos aspectos não acabado, cursivo e durativo. Isto realmente parece ser verdade, como podemos ver nos exemplos (615) a (629).

615. Comendo alegremente, os convidados perguntavam quando apareceria o aniversariante. (imperfectivo, não acabado, cursivo, durativo).

616. Você, varrendo a casa, não terá achado a abotoadura que perdi?(imperfectivo, não acabado, cursivo, durativo).

617. Estando meio adoentado, não irei (ou vou) ao baile. (imperfectivo, não acabado, cursivo, durativo).

618. Confiando na justiça do diretor, espero um despacho favorável. imperfectivo, não acabado, cursivo, durativo).

619. Sendo bons, os meninos resolveram ajudá-lo. (imperfectivo, não acabado, cursivo, durativo).

620. Comprando fiado, pagava tudo mais caro. (imperfectivo, não acabado, habitual).

621. Raciocinando diferente dele não posso entender sua atitude (= porque raciocino...) (imperfectivo, não acabado, habitual).

622. Passaram por aqui soldados levando armas. (imperfectivo, não acabado, cursivo, durativo).

623. Na porta da igreja, havia crianças pedindo esmola. (imperfectivo, não acabado, cursivo, durativo).

624. Você vê aquele cavalo pastando? É meu. (imperfectivo, não acabado, cursivo, durativo). 
625. Manuel encontrará as roseiras brotando. (imperfectivo, não acabado, cursivo, durativo).

626. Admira-me que, sendo tão sagaz, você não tenha percebido nada. (imperfectivo, não acabado, indeterminado).

627. Mandei rezar uma missa para eles, mesmo não sendo religioso. (imperfectivo, não acabado, indeterminado).

628. Mesmo possuindo tantos bens, ele não se sente seguro. (imperfectivo, não acabado, cursivo, durativo).

629. Eu não podia (ou poderei) acreditar em tanta maldade, sabendo embora que ele não é nenhum santo. (imperfectivo, não acabado, cursivo, durativo).

A observação de exemplos como esses poderia nos levar a confirmar que o gerúndio realmente marca os aspectos indicados nos parênteses, entretanto isto nem sempre parece ocorrer. $\mathrm{Na}$ verdade, o aspecto expresso pelo gerúndio parece depender do tipo de oração desenvolvida, a que a reduzida de gerúndio corresponde e do tempo flexional em que está o verbo da principal. Vejamos alguns casos. Antes, porém, queremos esclarecer que as reduzidas de gerúndio, muitas vezes, podem ter mais de uma interpretação. Como não podemos referir aqui todas as interpretações de cada frase, ater-nos-emos apenas à interpretação que interessa ao raciocínio em questão, quase sempre a mais natural delas. Normalmente as outras interpretações possíveis não afetam o raciocínio feito. Quando isso ocorre é porque houve alteração do valor temporal da forma verbal.

Nas reduzidas de gerúndio adverbiais temporais, o gerúndio expressa aqueles aspectos, principalmente quando indica situação simultânea à situação expressa na principal (cf. exemplos 615 e 616) independente do tempo em que possa estar o verbo da principal. Se entretanto a reduzida de gerúndio adverbial temporal indicar situação anterior à situação expressa na principal temos o seguinte:

a) quando o verbo da principal estiver no pretérito perfeito do indicativo, o gerúndio parece ter aspecto acabado. Exemplos:

630. Dizendo isto, Vilma saiu de casa. (= Depois que disse isto...)

631. Chegando ao colégio, procuramos ver o mestre. (= Quando ou depois que chegamos ao colégio...)

b) quando o verbo da principal estiver no presente do indicativo ou no pretérito imperfeito do indicativo, o gerúndio parece não ter aspecto, porque a reduzida 
é a temporal que condiciona a habitualidade da situação da principal, desde que o presente do indicativo tenha valor temporal de presente.

632. Seu irmão era engraçado: entrando em casa, ia direto olhar o que havia na geladeira. (= Quando entrava...)

633. Ganhando um brinquedo novo, Marina esquece os outros por semanas. (= Quando ganha..)

634. Chegando ao colégio, procuro ver o mestre. (= Quando chego ao colégio...)

c) o gerúndio também parece não ter aspecto quando o verbo da principal está em uma forma com valor de futuro (futuro do presente, imperativo, presente do indicativo).

635. Em amanhecendo, partiremos deste lugar. (= Quando amanhecer...)

636. Chegando ao colégio, procurarei ver o mestre. (= Quando chegar...)

637. Amanhã, terminando o trabalho, chamo você. (=Quando terminar...)

638. Nascendo o bezerro, avise-me. (= Quando o bezerro nascer...)

Nas reduzidas de gerúndio adverbiais causais, o gerúndio expressa os aspectos a que nos referimos nos seguintes casos:

a. com os verbos estáticos, estando o verbo da principal no pretérito perfeito ou no pretérito imperfeito do indicativo, no futuro do presente ou no presente do indicativo. Se o verbo for de estado o presente deve ter valor de futuro, caso contrário, a reduzida será temporal. Veja exemplos (617) a (619).

b. com os verbos de situação dinâmica, estando o verbo da principal no presente do indicativo ou no pretérito imperfeito do indicativo. Veja exemplos (620) e (621).

Se entretanto o verbo da principal estiver no pretérito perfeito do indicativo ou no futuro do presente, a reduzida de gerúndio de verbo de situação dinâmica poderá ter mais de uma interpretação e, então, torna-se difícil atribuir à mesma um valor aspectual. Veja exemplos (639) e (640) abaixo e os comentários para cada um. 
639. Raciocinando diferente dele, não pude entender sua atitude.

640. Trabalhando mais do que Carlos, subirei de posto primeiro.

Se em (639) "raciocinando" fosse interpretado como "porque raciocinei", teríamos os aspectos perfectivo e acabado; mas, se fosse interpretado como "porque raciocino" ou "porque raciocinava", teríamos os aspectos imperfectivo, não acabado e habitual. Em (640), se interpretarmos "trabalhando" como "porque trabalhei", teremos aspectos perfectivo e acabado, se interpretarmos como "porque trabalho", teremos aspectos imperfectivo, não acabado e cursivo e se interpretarmos como "se trabalhar" não teremos aspecto. ${ }^{33}$ Como se pode ver, em tais casos parece impossível dizer que o gerúndio esteja marcando algum aspecto.

Nas reduzidas de gerúndio adjetivas, o gerúndio sempre marca os aspectos imperfectivo, não acabado, cursivo e durativo, independente do tempo em que esteja o verbo da principal. Veja exemplos (622) a (625). Em frases deste tipo, normalmente a reduzida de gerúndio é com verbos de situação dinâmica. Não encontramos exemplo com verbos estáticos, formando oração adjetiva reduzida de gerúndio.

Nas reduzidas de gerúndio adverbiais concessivas com verbos estáticos, temos os aspectos imperfectivo, não acabado, cursivo e durativo, desde que não tenhamos o verbo ser, caso em que os aspectos serão o imperfectivo, o não acabado e o indeterminado, independente do tempo em que está o verbo da principal (ver exemplos 626 a 629). Com os verbos de situação dinâmica, as reduzidas de gerúndio concessivas são pouco comuns. Quando aparecem, o aspecto possivelmente atualizado nelas depende do tempo do verbo da oração principal. Veja exemplos (641) e (642) abaixo.

641. Mesmo correndo, não o pegou. (= Mesmo tendo corrido...) (perfectivo, acabado).

642. Oferecendo embora todas as vantagens, não consigo bons empregados. (=Embora ofereça...) (imperfectivo, não acabado, habitual).

Nas reduzidas de gerúndio adverbiais condicionais, em que o verbo da principal normalmente está no futuro do presente, no futuro do pretérito ou no presente do indicativo com valor de futuro, o gerúndio não marca nenhum aspecto. Veja exemplos (643) a (647).

${ }^{33}$ Em (640) a interpretação mais natural parece ser "se trabalhar". 
643. Ficando aí, vocês não verão nada.

644. Chovendo, não sairemos de casa.

645. Estudando, aprenderias em pouco tempo.

646. Sendo necessário, faço todos os sacrifícios.

647. Diná tinha esperança de que tentando outra vez conseguiria.

Também quando denota modo ou meio, o gerúndio não marca nenhum aspecto. Veja exemplos (648) a (650).

648. Enriqueceu vendendo joias.

649. Aprende-se um ofício, praticando-o.

650. O ladrão abriu a porta servindo-se de gazua. ${ }^{34}$

Quando a reduzida de gerúndio equivale a uma coordenada aditiva, o possível aspecto que lhe podemos atribuir depende do tempo do verbo da outra oração. Assim, se tivermos pretérito perfeito do indicativo, o gerúndio terá aspectos perfectivo e acabado; se tivermos presente do indicativo ou pretérito imperfeito do indicativo, o gerúndio terá aspectos imperfectivo, não acabado e habitual; e se tivermos futuro do presente ou do pretérito o gerúndio não terá aspecto. Veja exemplos (651) a (655).

651. O vaso caiu no chão, despedaçando-se. (= despedaçou-se) (perfectivo, acabado).

652. O vento aqui sopra forte, levantando muito pó. (= e levanta muito pó) (imperfectivo, não acabado, habitual).

653. Eurípedes levantava cedo, pedindo café. (= e pedia café) (imperfectivo, não acabado, habitual).

654. O foguete subirá rapidamente, explodindo no ar (= explodirá no ar) (não há aspecto).

655. Se eu não avisasse, Da. Joana lavaria esta blusa com água sanitária, estragando-a. (= e a estragaria) (não há aspecto).

Observe-se que nestes casos o gerúndio denota uma situação imediata à situação expressa na outra oração.

Todas estas evidências nos permitem afirmar que o gerúndio, em si, não marca qualquer noção aspectual. O que temos, normalmente, é a atribuição ao ge-

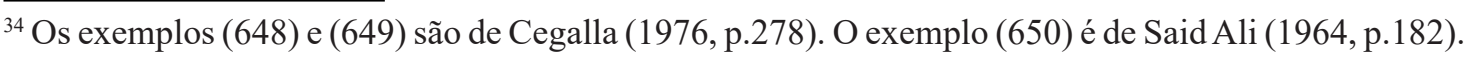


rúndio do valor aspectual que o verbo teria na oração desenvolvida, correspondente à oração reduzida de gerúndio. Estaríamos, então, atribuindo ao gerúndio um valor aspectual tirado da interpretação que damos à oração reduzida, normalmente em função do tempo da outra oração (principal ou coordenada) e do tipo da oração em que está o gerúndio.

O gerúndio neutraliza, na estrutura superficial, um valor aspectual que existiria numa estrutura profunda. Não nos parece adequado atribuir-lhe tal valor, uma vez que nem sempre podemos recuperá-lo com segurança através da interpretação semântica. Assim, em orações reduzidas de gerúndio, o melhor é dizer que o aspecto não se atualiza, principalmente quando temos várias possibilidades. Quando o valor aspectual pode ser detectado com segurança, podemos falar em aspecto nas orações reduzidas de gerúndio sempre com a devida cautela. Parece-nos que nas orações de gerúndio com verbos estáticos (normalmente causais e concessivas) e nas orações reduzidas de gerúndio adjetivas não há qualquer dúvida de que os aspectos imperfectivo, não acabado, cursivo e durativo se encontram atualizados (cf. exemplos 617 a 619 e 622 a 629). Nestes casos, há influência do semantema verbal e do tipo oracional.

\subsection{3 - PARTicíPIO}

O particípio, como já dissemos, marca o aspecto acabado, apresentando a situação como concluída. Isto pode ser observado, por exemplo, nas frases de números (656) a (666).

656. A notícia divulgada pela imprensa chocou a todos.

657. "Era um burrinho pedrês, miúdo e resignado, vindo de Passa Tempo" (Guimarães Rosa). ${ }^{35}$

658. Abertos os portões, o público começou a entrar.

659. Feito o exercício, podem sair.

660. Dado o sinal, os casais iniciavam os rodopios frenéticos.

661. Chegados à cabana, começaremos a limpá-la.

662. Surpreendidos pela chuva, ficaram todos molhados.

663. Perdido o medo, me aproximo dele.

664. Levantado o pano, começa a representação.

665. Lida a pergunta, ninguém se ofereceu para respondê-la.

666. Construída a casa, mudaríamos para lá imediatamente.

\footnotetext{
${ }^{35}$ Exemplo (657) apud Cegalla (1976, p.279).
} 
Normalmente o verbo da oração principal aparece no pretérito perfeito do indicativo, mas pode aparecer no presente do indicativo, às vezes com valor futuro, (exemplos, 659, 663 e 664), no pretérito imperfeito do indicativo (exemplo 657), no futuro do presente (exemplo 661) ou no futuro do pretérito (exemplo 666), sem alterar o valor aspectual do particípio. A mudança do tempo da oração principal altera o valor temporal do particípio que, em si, não marca o tempo da situação. Veja exemplos (667) a (669) tomados a Cunha (1975, p.465).

667. Aprovada a lei, só nos restava cumpri-la. (passado) (acabado).

668. Aprovada a lei, só nos resta cumpri-la. (presente) (acabado).

669. Aprovada a lei, só nos restará cumpri-la. (futuro) (acabado).

Quando o particípio indica um estado resultante de uma ação que se concluiu o acabado é da situação narrada representada pela ação. A situação referencial, representada pelo estado indicado pelo particípio, tem aspectos imperfectivo, não acabado, cursivo, durativo. Veja exemplos (670) a (674).

670. Abraçada com o filho, Raquel chorou muito. (= Raquel que estava abraçada com o filho chorou muito)

a) S.N.: abraçar - acabado.

b) S.R.: estado de abraçada - imperfectivo, não acabado, cursivo, durativo.

671. Sitiada pelo inimigo, a cidade não se rende. (= Embora esteja sitiada pelo inimigo...)

a) S.N.: sitiar - acabado.

b) S.R.: estado de sitiado - imperfectivo, não acabado, cursivo,durativo.

672. Sobre a cidade, adormecida pela noite, paira uma ameaça. (= Sobre a cidade que está adormecida...)

a) S.N.: adormecer - acabado.

b) S.R.: estado de adormecida - imperfectivo, não acabado, cursivo, durativo.

673. Meu irmão, extremamente irritado, não parou um só minuto. (= Meu irmão, que estava extremamente irritado).

a) S.N.: irritar - acabado.

b) S.R.: estado de irritado - imperfectivo, não acabado, cursivo, durativo. 
674. Muito ocupado com o trabalho, não percebeu o que o filho fazia. (= Porque estava muito ocupado com o trabalho...)

a) S.N.: ocupar - acabado.

b) S.R.: estado de ocupado - imperfectivo, cursivo, não acabado, durativo.

É interessante observar que não temos orações reduzidas de particípio com os verbos estáticos. Se tentamos construir tal tipo de orações, obtemos frases inaceitáveis dentro da língua.

O que pudemos observar sobre a expressão do aspecto pelas flexões verbais está aqui anotado. Nem tudo ficou claro e preciso, mas o esclarecimento total de certas questões exige um estudo particular, podendo mesmo ser objeto de outros trabalhos.

Como se pôde ver é praticamente impossível falar apenas de um meio de expressão, pois a constante interferência de outros meios e fatores diversos nos obriga a comentá-los, quando aparecem agindo em conjunto com o meio de expressão em foco. Isto se verifica não só para as flexões verbais, mas também para os demais meios de expressão do aspecto. 
O aspecto verbal no Português: a categoria e sua expressão 


\section{8 - Expressão do aspecto pelas perífrases verbais}

\section{1 - OBSERVAÇÕES GERAIS}

Inicialmente é preciso esclarecer que estaremos chamando de perífrase qualquer aglomerado verbal em que tenhamos um verbo (denominado auxiliar) ao lado de outro verbo em uma das formas nominais (denominado principal), e com uma função determinada de marcar uma categoria gramatical ou uma noção semântica qualquer. Não vamos discutir aqui o conceito de auxiliaridade. Primeiro porque foge a nossos objetivos e, segundo, porque se temos ou não auxiliares reais isso não afeta grandemente o problema da expressão do aspecto. Sobre a questão da auxiliaridade consultem-se os trabalhos de Lobato (1975) e Pontes (1973).

Algumas das funções que as perífrases podem ter são, por exemplo:

a. marcar o aspecto, como é o caso de ESTAR + GERÚNDIO ou CONTINUAR + GERÚNDIO. Exemplos:

675. Rogério estava almoçando, quando telefonei. (imperfectivo, cursivo, não acabado, durativo).

676. Todos continuarão escrevendo sobre o problema. (começado).

b. marcar a voz, como é o caso de SER + PARTICÍPIO, que indica voz passiva. Exemplo:

677. As meninas foram encontradas pelo policial.

c. marcar o tempo, como é o caso de IR + INFINITIVO que indica futuro. Exemplos: 
678. Vamos atravessar o rio a nado.

679. Os cavalos vão partir dentro de instantes.

d. marcar modalidade. Exemplos:

680. Tenho de limpar a casa hoje. (obrigação - TER + DE + INFINITIVO)

681. Quero ir ao parque. (volição - QUERER + INFINITIVO)

682. Devo ler este livro para fazer o trabalho. (necessidade - DEVER + INFINITIVO)

e. marcar determinadas noções semânticas, tal como a registrada nos exemplos abaixo.

683. Só sei que ele veio a comprar a fazenda do Sr. Miguel. (resultado final - VIR + A + INFINITIVO)

684. O rapaz acabou confessando sua culpa. (resultado final - ACABAR + GERÚNDIO)

Muitas vezes a perífrase marca duas coisas ao mesmo tempo. Veja-se os exemplos abaixo:

685. O carteiro tinha entregue o telegrama, quando cheguei. (TER + PARTICÍPIO. Aspecto: acabado; tempo: passado relativo, anterioridade).

686. A tinta vai esparramando sobre o papel. (IR + GERÚNDIO: noção semântica: progressão; aspecto: durativo)

687. O rapaz está para saltar sobre o animal. (Aspecto: não começado; tempo: futuro próximo).

Naturalmente, interessam-nos aqui, de forma mais direta as perífrases que marcam aspectos. Por vezes comentaremos perífrases não marcadoras desta categoria, apenas para deixar isto claro. Para facilidade de exposição, agrupamos as perífrases ou pelo auxiliar de que são formadas, ou pelo tipo de aspecto que expressam.

No estudo dos aspectos expressos pelas perífrases, utilizamos como principais verbos télicos e atélicos, verbos estáticos (de estado ou não), verbos de 
situações dinâmicas (processos e eventos) e verbos transformativos. ${ }^{1}$ Observar-se-á que, muitas vezes, o tipo de verbo principal altera o aspecto expresso pela perífrase.

\section{2 - AS PERÍFRASES DE TER E HAVER}

\subsection{1 - TER + PARTICÍPIO}

A perífrase TER + PARTICÍPIO expressa em todos os tempos e formas nominais, exceto no presente do indicativo, e com qualquer tipo de verbo principal os aspectos perfectivo e acabado. Exemplos:

688. Orlando tinha roncado à noite e ela estava nervosa por isso.

689. Muitas bombas terão explodido antes que prendam os guerrilheiros.

690. Eu teria emoldurado muitos quadros se a cola não tivesse acabado.

691. Embora Pedro tenha estado feliz durante o dia, à noite sentia-se deprimido.

692. Se esse menino tivesse engolido a bola de gude, teríamos de levá-lo ao médico.

693. Quando tiverem nascido muitos filhotes, começaremos a seleção.

694. José ter caminhado de manhã, deixou-o bem disposto.

695. Tendo chovido muito, as ruas estavam inundadas.

Essa perífrase não é usada nem no pretérito perfeito do indicativo, nem no pretérito mais-que-perfeito do indicativo, provavelmente porque estes dois tempos marcam o aspecto perfectivo e o segundo deles marca também o acabado e haveria então dois recursos, para expressão da mesma noção, o que iria contra o princípio de economia da língua. Said Ali (1971, p.162, § 826) registra que esta perífrase foi usada no pretérito perfeito do indicativo, mas que tal forma foi banida pelo uso como supérflua, uma vez que tinha o mesmo valor do pretérito perfeito do verbo principal. Dias (1970, p.191-192) registra alguns exemplos deste uso. Abaixo transcrevemos os dois exemplos apresentados por Said Ali.

696. "Depois que el Rei teve determinado de pelejar... mandou duas gallees." (Fernão Lopes - D. J. 26).

697. E como teve feito nella o que quiz, foi cercar D. João no forte em que esteve. (Couto - Déc. 4, 10,6).

\footnotetext{
${ }^{1}$ Chamamos de verbos transformativos aqueles que expressam uma mudança de estado ou de forma.
} 
Os dois autores afirmam que a perífrase, neste tempo, era usada para indicar que em um momento do passado a ação estava consumada.

No presente do indicativo, a perífrase em questão marca o imperfectivo, o não acabado e o iterativo. Por influência do tipo do verbo principal, podemos ter o durativo e o cursivo no lugar do iterativo. Vejamos alguns exemplos:

698. Nei Matogrosso tem cantado na televisão. (imperfectivo, iterativo, não acabado).

699. Meu irmão tem mandado notícias. (imperfectivo, iterativo, não acabado).

700. Tenho caminhado de manhã. (imperfectivo, iterativo, não acabado).

701. O rapaz tem partido pela manhã. (imperfectivo, iterativo, não acabado).

702. Tenho amado você desde que a conheci. (imperfectivo, cursivo,durativo, não acabado).

703. O paciente tem respirado bem. (imperfectivo, cursivo, durativo, não acabado).

704. Nos últimos anos Marta tem vivido modestamente. (imperfectivo, cursivo, durativo, não acabado).

O cursivo tende a ser expresso, quando os verbos indicam situações que não aceitam descontinuidade. É o caso dos verbos de sentimentos (exemplo 702) e de verbos como "respirar" ou "viver". (exemplos 703 e 704).

Com os verbos de estado, devido o seu valor durativo, a iteratividade se enfraquece e a forma é, muitas vezes, sentida como tendo aspectos durativo e cursivo. Exemplos:

705. Pedro tem estado contente. (imperfectivo e não acabado) (cursivo e durativo ou iterativo?)

706. Rafael tem andado preocupado com você. (imperfectivo e não acabado) (cursivo e durativo ou iterativo?)

707. Não se preocupe. Marieta tem sido feliz a seu modo. (imperfectivo, cursivo, durativo, não acabado)

708. Júlio tem sido muito gentil comigo. (imperfectivo e não acabado) (cursivo e durativo ou iterativo?)

709. a - Jorge tem ficado calado. (imperfectivo e não acabado) (cursivo e durativo ou iterativo?) 
b - Jorge tem ficado calado nas reuniões. (imperfectivo, iterativo, não acabado)

Nos casos em que há dúvida parece haver uma tendência maior para a interpretação durativa e cursiva. Entretanto, a opção entre cursivo e durativo por um lado e iterativo do outro depende muito do contexto em que o falante situa a frase. Assim, por exemplo, em (708), se o falante estiver considerando atos de gentileza, teremos o iterativo com toda certeza. Em (709-b) o iterativo é claramente definido em função do adjunto adverbial "nas reuniões".

Também com os verbos transformativos há o mesmo tipo de problema. Se o verbo transformativo expressa um evento, teremos imperfectivo não acabado e iterativo como no exemplo (710).

710. José tem adoecido, o que me impede de sair.

Mas se expressa um processo, podemos ter tanto uma interpretação iterativa como uma interpretação durativa e cursiva. Não parece haver qualquer sistematização possível, mas a interpretação durativa e cursiva aparece mais vezes, quando o verbo é intransitivo ou usado como tal. Exemplos:

711. José tem engordado muito. (imperfectivo, não acabado, durativo, cursivo)

712. As folhas do álbum têm amarelado de uns tempos para cá. (imperfectivo, não acabado, durativo, cursivo)

713. A fumaça tem empretejado as paredes. (imperfectivo, não acabado, durativo, cursivo)

714. a - José tem arredondado esta pedra. (imperfectivo, iterativo, não acabado).

b - José tem arrendondado estas pedras. (imperfectivo, não acabado, iterativo).

c - José tem arredondado pedras. (imperfectivo, não acabado, iterativo).

715. Precisamos mudar a fórmula, pois a massa tem endurecido muito rápido. (imperfectivo, não acabado, iterativo).

716. Carlos tem afinado muito a ponta dos espetos. (imperfectivo, iterativo, não acabado).

717. O antiquário tem amarelado folhas de papel para fazer imitações de originais antigos. (imperfectivo, não acabado, iterativo). 
Nestes casos, um adjunto adverbial pode marcar ou reforçar a iteratividade. Exemplos:

718. As folhas têm amarelado em agosto. (imperfectivo, habitual, não acabado).

719. José tem arredondado pedras toda manhã. (imperfectivo, iterativo, não acabado).

Como se pode observar, o fato de termos iterativo ou cursivo e durativo parece depender do significado próprio do verbo e do contexto.

Pode-se, então, dizer que a perífrase "ter + particípio", no presente do indicativo, expressa o imperfectivo, o não acabado e o iterativo, mas que, em certos casos, em função principalmente do significado do verbo, temos o durativo e o cursivo, e não o iterativo.

Devido a este valor iterativo, quando o verbo indica uma situação que não se repete para o mesmo ser, o sujeito (se o verbo for intransitivo) ou o objeto (se o verbo for transitivo) terão que ser plurais, conter a ideia de pluralidade ou poder ser tomados num sentido genérico. Em caso contrário teremos uma frase estranha ou inaceitável. Exemplos:

720. a - Tenho emoldurado muitos quadros. (imperfectivo, iterativo, não acabado).

b - (?) Tenho emoldurado um quadro.

O exemplo (720b) pode ter uma interpretação imperfectiva e iterativa, em que se estaria dizendo que a pessoa trabalha em diferentes períodos na emolduração do quadro. Entretanto (720b) não é a forma mais natural que um falante do Português usaria para expressar tal ideia. Provavelmente ele diria algo como: "Trabalho (ou tenho trabalhado) todos os dias na emolduração de um quadro". Outra interpretação de (720b) seria imperfectiva, durativa e cursiva, mas seria igualmente estranha por não ser a forma mais natural de expressar o pensamento em questão. O falante do Português preferiria dizer "Estou emoldurando um quadro" ou "Venho emoldurando um quadro".

721. a - Têm nascido muitos filhotes ultimamente. (imperfectivo, iterativo, não acabado).

b - * Tem nascido um filhote. 
722. a - Esse menino tem engolido coisas estranhas. (imperfectivo, iterativo, não acabado).

b - * Esse menino tem engolido uma bolinha de gude.

723. a - Muitas bombas têm explodido ultimamente. (imperfectivo, iterativo, não acabado).

b - * Uma bomba tem explodido ultimamente.

724. a - Têm morrido muitas rezes com a peste. (imperfectivo, iterativo, não acabado).

b - *Tem morrido uma rês com a peste.

De (721) a (724), as frases b são inaceitáveis, porque o verbo expressa um evento, o que impossibilita interpretações semelhantes às dadas a (720b).

Com processos atélicos e a colocação de um elemento adverbial que marca o momento de início do processo, a perífrase no presente do indicativo permite uma interpretação imperfectiva, durativa e cursiva, entretanto a frase, nestes casos, não é a mais natural para expressão do pensamento em causa e soará como estranha ou totalmente inaceitável. Exemplos:

725. a - ? José tem caminhado desde as cinco horas.

b - ? José tem cantado desde as vinte horas.

Para expressão das ideias contidas em $(725 \mathrm{a}, \mathrm{b})$ com interpretação durativa e cursiva o falante do Português prefere frases como (726):

726. a - José está caminhando desde as cinco horas.

b - José está cantando desde as vinte horas.

Dias (1970, p.190) dá um exemplo em que a perífrase ter + particípio no presente do indicativo marcaria aspecto acabado e que transcrevemos abaixo (exemplo 727). ("Também serve de exprimir que no momento em que a pessoa falla, uma acção está consumada...”).

727. Tenho acabado, Fiéis, o meu discurso (VIEIRA, I, 950).

Esse tipo de construção não se usa mais e um exemplo como (727) tende a ser interpretado como tendo a perífrase sobre que falamos em 8.2.3. 
Câmara Júnior (1974a) diz que, em construções como (728), a perífrase marca o cursivo. Realmente isto acontece, mas o que temos aqui, na verdade, é uma construção com a perífrase de 8.2.3 adiante.

728. "O nome que no peito escrito tinhas" (Lus. III - 120).

\subsection{2 - HAVER + PARTICÍPIO}

A perífrase HAVER + PARTICÍPIO tem o mesmo valor aspectual que a perífrase TER + PARTICÍPIO, valendo para aquela os comentários feitos para esta. Eis alguns exemplos em que podemos observar que haver + particípio marca os aspectos acabado e perfectivo:

729. Quando cheguei, Marina havia picado a carne.

730. Seu primo haverá chegado, quando voltarmos à fazenda.

731. Embora Joel haja falado comigo, não posso fazer nada.

732. Se ele houvesse emagrecido um pouco, a roupa lhe ficaria melhor.

733. Havendo trazido o livro, pediu-me que lesse para ele.

É importante observar que a perífrase haver + particípio não é usada no presente do indicativo e que as frases construídas com esta forma são inaceitáveis. Exemplos:

734. * Milton há cantado em muitas cidades do interior.

735. * Mamãe há preparado um frango delicioso.

736. * Os alunos hão falado que suas aulas são excelentes.

737. * Havemos recebido muitos convites.

\subsection{3 - TER + PARTICÍPIO VARIÁVEL}

A perífrase TER + PARTICÍPIO (variável) expressa os aspectos imperfectivo, cursivo, não acabado e durativo, para a situação referencial, que é um estado, e o acabado para a situação narrada de cujo término resultou o estado expresso. Isto com todos os tempos flexionais, exceto com os pretéritos perfeito e mais-que-perfeito do indicativo, em que temos o perfectivo, o acabado e o durativo para a situação referencial e o acabado para a situação narrada. Esta perífrase geralmente aparece em construções do tipo TER + OBJETO + PARTICÍPIO, onde o particípio tem a função de um predicativo do objeto com o qual concorda em gênero e número. 
Diante disso, podemos considerar o verbo ter, nestas construções, como um verbo relacional $^{2}$ e o particípio como um adjetivo. Como se poderá ver, isto é inteiramente válido, pois, neste caso, o verbo ter se comporta exatamente como um verbo de estado no que se refere à expressão do aspecto.

Vejam-se os exemplos (72) e (73) que reescrevemos e (738) a (747) abaixo.

Tenho a lição estudada.

a) S.R.: ter estudada - imperfectivo, cursivo, não acabado, durativo.

b) S.N.: estudar a lição - acabado.

73 Bernarda (que vestiu um casaco e tem posta uma mantilha preta. A observar Amália com desconfiança): "Estás hoje muito janeleira, Amália!" - B. Santareno.44

a) S.R.: ter posta - imperfectivo, cursivo, não acabado, durativo.

b) S.N.: Pôr a mantilha - acabado.

$738 \quad \mathrm{O}$ menino tinha o animal preso em casa.

a) - S.R.: ter preso - imperfectivo, cursivo, não acabado, durativo.

b) - S.N.: prender o animal - acabado.

739 Ele terá a massa preparada, quando for o momento de usá-la. a - S.R.: ter preparada - imperfectivo, cursivo, não acabado, durativo. b - S.N.: preparar a massa: acabado.

740 Eu teria a casa lavada, se a água não tivesse acabado. a - S.R.: ter lavada - imperfectivo, cursivo, não acabado, durativo. b - S.N.: lavar a casa - acabado.

741 É importante que você tenha os animais presos, quando chegarmos. a - S.R.: ter presos - imperfectivo, cursivo, não acabado, durativo. b - S.N.: prender os animais - acabado.

742 Embora Ademilde tivesse os retalhos cortados, não montou a colcha.

a - S.R.: ter cortados - imperfectivo, cursivo, não acabado, durativo. b - S.N.: cortar os retalhos - acabado.

743 Se você tiver a conferência preparada, poderá fazê-la hoje. a - S.R.: ter preparada - imperfectivo, cursivo, não acabado, durativo. b - S.N.: preparar a conferência - acabado.

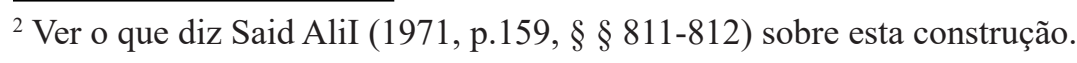


744. Termos muitos quadros emoldurados é uma vantagem. a - S.R.: ter emoldurados - imperfectivo, cursivo, não acabado,durativo.

b - S.N.: emoldurar os quadros - acabado.

745. Tendo a mesa posta quando chegarem, poderemos servir com maior presteza.

a - S.R.: ter posta - imperfectivo, cursivo, não acabado, durativo.

b - S.N.: pôr a mesa - acabado.

746. Cecília teve os olhos postos em você durante muito tempo.

a - S.R.: ter postos - perfectivo, acabado, durativo.

b - S.N.: pôr os olhos em - acabado.

747. O soldado tivera a arma apontada para o presidente, mas desistiu de atirar.

a - S.R.: ter apontada - perfectivo, acabado, durativo.

b - S.N.: apontar a arma em - acabado.

Castilho (1967), que caracteriza o perfectivo como acabado, apresenta frases do tipo de (72) e (73) como tendo aspecto Perfectivo Resultativo em virtude do acabado da situação narrada. Esta não nos parece a melhor análise, já que não são considerados os aspectos presentes na situação referencial.

A construção correspondente a "ter + objeto + particípio variável" com o verbo haver, que para alguns teria o mesmo valor, não é usada hoje em dia, e as frases com ela formadas são sentidas como estranhas ou inaceitáveis pelos falantes.

É interessante observar que existem algumas restrições ao uso desta perífrase. ${ }^{3} \mathrm{Na}$ verdade, esta construção só é possível com verbos que se encaixem em um dos esquemas de (748). Nestes o termo "afetado" indica que o verbo deve expressar uma situação, de cuja conclusão resulte um estado novo e duradouro no objeto ou sujeito, conforme o caso.

748.

$$
\begin{aligned}
& \text { a - Sujeito agente }+ \text { verbo }+ \text { objeto afetado. } \\
& \text { b - Sujeito afetado }+ \text { verbo. }
\end{aligned}
$$

\footnotetext{
${ }^{3}$ Ao realizar o estudo da expressão do aspecto pelas perífrases encontramos uma série de restrições ao uso das mesmas com certos tipos de verbos, ou em certos contextos. Não vamos no corpo deste trabalho expôr estas restrições, porque estaríamos fugindo a nosso objetivo primeiro e para evitar constantes interrupções na exposição daquilo que, basicamente, constitui nosso estudo. As restrições ao uso de "ter + objetivo + particípio variável" que expomos ficam a título de exemplo.
} 
Eis alguns exemplos em que se pode observar a ação da restrição acima.

749. * Tenho o trem partido desde cedo.

750. * Maria tem um rapaz amado.

751. * Temos a peça achada para você.

Verbos como chegar, respirar, nascer, chover, etc. não aceitam a construção. Os verbos transformativos, embora indiquem situações de cuja conclusão resulte um estado novo em um ser, parecem não admitir a construção. Esta sempre soa como estranha, principalmente quando se tem um adjetivo de sentido exatamente igual ao do particípio. Veja exemplos (752) e (753) abaixo.

752. ? José tem as porcas engordadas.

753. ? Tenho as folhas amareladas.

Naturalmente, com interpretações um pouco diferentes, (752) e (753) são mais aceitáveis.

É interessante observar que as restrições de uso de "ter + objeto + particípio" são as mesmas de "estar + particípio".

\section{3 - As PERÍFRASES DE ESTAR}

Antes de mais nada é preciso observar que todas as perífrases de estar marcam exatamente os mesmos aspectos que o verbo estar (ver item 9.1). Isto equivale a dizer que as perífrases de estar marcam os aspectos imperfectivo, cursivo, não acabado e durativo em todos os tempos flexionais e formas nominais, exceto nos pretéritos perfeito e mais-que-perfeito do indicativo em que expressam os aspectos perfectivo, acabado e durativo. Estes aspectos dizem respeito sempre à situação referencial. Como veremos, a diferença entre estas perífrases está normalmente no aspecto que atribuem à situação narrada. Vejamos cada uma delas e suas particularidades.

\subsection{1 - ESTAR + POR/PARA/EM + INFINITIVO}

Inicialmente temos as perífrases ESTAR + POR + INFINITIVO, ESTAR + PARA + INFINITIVO e ESTAR + EM + INFINITIVO que marcam o aspecto não começado para a situação narrada, representada pelo infinitivo. Nestas três perífrases os elementos "por + infinitivo", "para + infinitivo" e "em + infinitivo" valem por estados, sendo que o primeiro deles é o que mais facilmente se sente como tal. 
A perífrase ESTAR + POR + INFINITIVO pode ser observada em exemplos como (34), (132), que reescrevemos abaixo, e (754) a (764).

34. Esta gaveta está por arrumar, mas só o farei quando tiver tempo.

132. A cozinha está por limpar.

754. Os quadros estavam por emoldurar, quando chegamos lá.

755. Se você continuar nesta moleza, as batatas estarão por fritar quando o pessoal chegar.

756. A escravidão estaria por abolir, se não tivesse havido os que lutaram pela abolição.

757. Embora a ponte ainda esteja por explodir, o inimigo não conseguirá atravessar o rio.

758. Embora a música estivesse por gravar, ela não compareceu ao estúdio.

759. Se os folhetos ainda estiverem por distribuir, você será despedido.

760. O livro estar por encadernar até hoje mostra o quanto você é relapso.

761. As paredes estando por pintar, quero que você escolha as cores.

762. O ginásio esteve por construir todo esse tempo, mas hoje é uma realidade.

763. Esta casa esteve por limpar até hoje.

764. Este artigo estivera por escrever mais de um mês, mas agora pude fazê-lo graças a sua ajuda.

Nas frases (34), (132) e (754) a (761) a situação referencial, que é um estado, tem os aspectos imperfectivo, cursivo, não acabado e durativo e a situação narrada tem aspecto não começado. Nas frases (762) a (764), a situação referencial tem aspectos perfectivo, acabado e durativo e a situação narrada tem aspecto não começado.

"Por + infinitivo" representa o estado do ser designado pelo sujeito, antes da realização da situação narrada.

Só admitem esta construção os verbos que se encaixem no esquema de (748 a). Aqui o sujeito é sempre o objeto afetado, o que gera uma certa passividade na significação das frases com "estar + por + infinitivo". Se o verbo, no sentido considerado, não admite a construção, e o sujeito é potente, a frase é interpretada pelo falante com um sentido semelhante ao de "estar + para + infinitivo". Veja exemplos (765) e (766). 
765. O trem está por partir. (= está para partir).

766. O avião está por chegar. (= está para chegar).

Frases como estas, embora possíveis com semelhante interpretação, não são usadas e são vistas como pouco naturais pelos falantes. Estes preferem marcar a iminência de ação com a perífrase "estar + para + infinitivo".

As frases formadas com verbos que geralmente só se encaixam no esquema (748 b) são estranhas ou ruins. Veja exemplo (767).

\section{7. * José está por adoecer.}

Se o verbo se encaixa tanto no esquema de (748a), quanto no de (748b), a frase será ruim no sentido que se encaixa em (748b) e boa no sentido que se encaixa em (748a). Exemplos:

768. a - A barreira está por arrebentar. (Alguém está encarregado de arrebentar a barreira)

b - *A barreira está por arrebentar. (A barreira vai arrebentar).

769. a - As porcas estão por engordar. (Alguém vai engordar as porcas. Engordar = cevar).

b - *As porcas estão por engordar. (Engordar = ficar gordo).

A perífrase ESTAR + PARA + INFINITIVO se distingue de "estar + por + infinitivo", por marcar a noção temporal de futuro próximo, que se traduz na iminência de ação, além de marcar as noções aspectuais que já especificamos. Vejamos os exemplos (7 c), (35), (36) e (770) a (777) abaixo.

7c. Sua encomenda está para chegar.

35 . Pedro está para emoldurar o quadro.

36. Seu irmão está para chegar.

770. Estava para chover e ela ficou preocupada, pois a filha estava na rua.

771. A bomba estará para explodir, quando a encontrarem.

772. Embora o trem esteja para partir vocês ainda poderão tomá-lo.

773. Embora os filhotes estivessem para nascer, todos estavam calmos na fazenda.

774. Você estar para caminhar de novo deixa todos felizes. 
775. Estando para mudar, não quis pintar a casa de novo.

776. Seu tio esteve para morrer, mas este médico conseguiu salvá-lo.

777. Ivan estivera para confessar a verdade ao irmão, mas achou melhor calar-se.

Nas frases (7c), (35), (36) e (770) a (775), a situação referencial tem os aspectos imperfectivo, cursivo, não acabado, durativo e a situação narrada o não começado. Nas frases (776) e (777), a situação referencial tem aspectos perfectivo, acabado e durativo e a situação narrada o não começado.

Como já dissemos, "para + infinitivo" tem um valor de estado que se torna mais claro, quando o verbo estar tem sentido de "ter disposição ou intenção" (exemplos 778 a 780). Neste caso a ideia de iminência de ação desaparece.

778. Não estou para ouvir tolices.

779. Naquele tempo eu não estava para amar alguém.

780. Ela me disse que não está para continuar fechada em casa.

O aspecto aqui é o mesmo de (7 c), (35), (36) e (770) a (775).

Quando a perífrase "estar + para + infinitivo" marca iminência de ação a noção aspectual aparece um pouco enfraquecida.

A perífrase de ESTAR + EM + INFINITIVO que, segundo Dias (1970, p.232), tem o mesmo valor de "estar + por + infinitivo", no que respeita a indicar algo ainda não realizado, tem o mesmo valor aspectual desta, como já vimos, mas difere por trazer em si a ideia de "ter disposição ou intenção". Vejamos alguns exemplos:

781. "Estamos em partir amanhã”. (T. Silva Brandão).

782. "Estou em dizer que toda matungama / não vale a poeira que bulir na estrada" (Vargas Neto - Tropilha, Crioula e Gado Xucro). ${ }^{4}$

783. Meu irmão esteve em pedir-lhe o terno emprestado, mas ficou com vergonha de fazê-lo.

Em (781) e (782) a situação referencial tem os aspectos imperfectivo, cursivo, não acabado e durativo, enquanto em (783) tem o perfectivo, o acabado e o durativo. Nas três frases a situação narrada tem o aspecto não começado.

\footnotetext{
${ }^{4}$ Exemplo (781) apud Fernandes (1965, p.324), verbete “estar". (FERNANDES, F. Dicionário de verbos e regimes. Porto Alegre: Globo, 1965.). Exemplo (782) apud Ferreira (1975, p.578), verbete "estar". (FERREIRA, A. B. de H. Novo dicionário da língua portuguesa. Rio de Janeiro: Nova Fronteira, 1975. 1499p.)
} 
A perífrase "estar + em + infinitivo" praticamente não é usada hoje em dia e “estar + para + infinitivo" vem tomando seu lugar (ver exemplos 778 a 780).

\subsection{2 - ESTAR + GERÚNDIO}

A perífrase ESTAR + GERÚNDIO não traz a questão da distinção entre situação narrada e referencial. Temos apenas uma situação que, com todas as flexões verbais, exceto os pretéritos perfeito e mais-que-perfeito do indicativo, apresenta os aspectos imperfectivo, cursivo, não acabado e durativo como se pode observar nos exemplos (784) a (793).

784. As folhas da avenca estão amarelando.

785. O bebê estava nascendo, quando me avisaram.

786. Quando você for procurar Maria, ela já estará amando outro.

787. Hilário estaria pesquisando este assunto, se você não o tivesse desanimado.

788. Embora Neilton esteja folheando o livro, não o está lendo.

789. Embora estivesse ventando muito, Aníbal saiu com o barco.

790. Se a água estiver fervendo, desligue o fogo para mim.

791. Quando José estiver adoecendo, virá nos pedir socorro.

792. O paciente estar respirando bem é um bom sintoma.

793. Estou emoldurando vários quadros para ele.

Muitas vezes, por influência do adjunto adverbial, temos uma interpretação iterativa. Nestes casos, o adjunto adverbial marca o iterativo ou o habitual, contrariando a tendência aspectual da perífrase. Exemplos:

794. O trem está partindo pela manhã. (imperfectivo, não acabado, iterativo).

795. a - O rapaz estava chegando às oito horas.

b - Todos os dias o rapaz estava chegando às oito horas.

A frase (795a) é ambígua, podendo ser iterativa ou não, já (795b) só pode ser iterativa.

796. Hoje em dia os bebês estão nascendo mais fortes (imperfectivo, não acabado, habitual).

797. José está caminhando de manhã (ou toda manhã). (imperfectivo, não acabado, iterativo). 
Com o auxiliar nos pretéritos perfeito e mais-que-perfeito do indicativo, os aspectos marcados serão o perfectivo, o acabado e o durativo como se pode observar nos exemplos (798) a (802).

798. Esse menino esteve comendo doces a tarde toda.

799. Mamãe esteve caminhando pelo bosque hoje de manhã.

800. Seu filho esteve cantando para nós, mas já se foi.

801. Estivera chovendo de manhã e todos ficaram em casa.

802. Pedro estivera olhando algumas camisas, mas não gostou de nenhuma.

Com a perífrase nestes dois pretéritos, temos um valor cessativo que torna estranhas ou ruins frases com verbos de evento (exemplos: 803 e 804); com verbos de processo que não aceitam descontinuidade, como amar e respirar (exemplo: 805); com verbos de estado que por si já marcam o acabado, quando nos pretéritos perfeito ou mais-que-perfeito do indicativo (exemplo 806); com certos verbos transformativos, não agentivos (exemplos: 807 e 808).

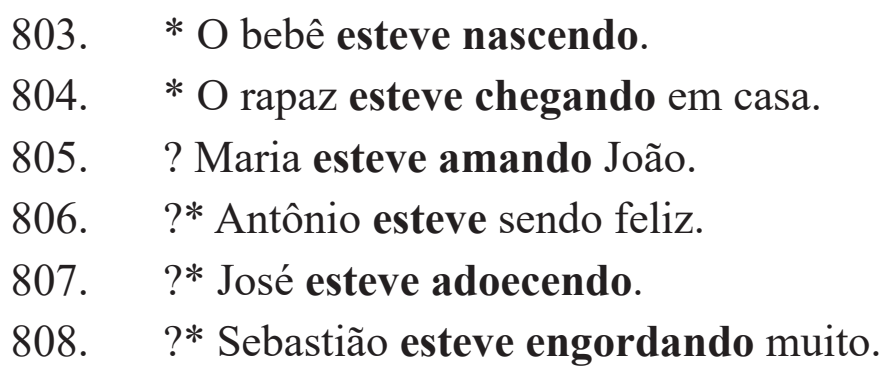

As frases com verbos de evento parecem se tornar mais aceitáveis, quando uma interpretação iterativa é possível, seja por influência de um adjunto adverbial seja porque temos um sujeito plural, se o verbo é intransitivo, ou um objeto plural se o verbo é transitivo. Exemplos:

809. a - Os trens estiveram partindo pela manhã. (perfectivo, acabado, iterativo).

b - O trem esteve partindo pela manhã. (perfectivo, acabado, iterativo).

810. Os filhotes estiveram nascendo fracos, mas agora está tudo bem. (perfectivo, acabado, iterativo).

811. Os homens estiveram explodindo bombas a noite toda. (perfectivo, acabado, iterativo). 
812. $\mathrm{O}$ rapaz esteve chegando em casa às oito horas todos os dias (perfectivo, acabado, iterativo).

Como se pode observar, mesmo sendo possíveis, estas frases soam como pouco naturais e (812) é bastante estranha. Na verdade, os pensamentos registrados em (809) a (812) são mais naturalmente expressos, quando se usa a perífrase "andar + gerúndio".

A perífrase ESTAR + A + INFINITIVO, que é pouco usada no Brasil, tem o mesmo valor aspectual que a perífrase "estar + gerúndio", sendo válidos para aquela os comentários feitos para essa. Quanto à exemplificação, é suficiente mudar nas frases (784) a (812) o "gerúndio" por "a + infinitivo". Cumpre apenas anotar que estar $+\mathrm{a}+$ infinitivo é possível com o auxiliar no gerúndio, o que não ocorre com sua equivalente. Veja exemplos (813) a (816) em que temos sempre os aspectos imperfectivo, cursivo, não acabado e durativo.

813. Estando o ônibus a partir não pudemos tomá-lo.

814. Estando a caminhar desde cedo, ao meio dia Edgar sentiu-se cansado.

815. Estando a cantar, mamãe não me ouviu chegar.

816. Estando a chegar naquele instante, o rapaz não sabia de nada.

\subsection{3 - ESTAR + PARTICÍPIO}

A perífrase ESTAR + PARTICÍPIO se diferencia aspectualmente das demais perífrases de estar, por apresentar a situação narrada como acabada. O particípio representa sempre um estado e funciona como nome predicativo. Exemplos:

817. O assaltante está preso.

818. A porta estava arrebentada.

819. O poço estará furado, quando vocês mudarem para cá.

820. Antônio estaria morto, se não o tivessem tirado da água.

821. Embora os rapazes estejam irritados, falarei com eles agora.

822. Se a carne estivesse picada, eu poderia prepará-la para você.

823. Se o livro estiver lido, podemos fazer o debate hoje.

824. A porta estar aberta me pareceu estranho.

825. Os folhetos estando distribuídos podemos começar o trabalho.

826. Meu cachorro esteve acorrentado durante três dias.

827. Essa casa já esteve limpa hoje.

828. Meu primo estivera sumido por duas semanas, sem dar notícia. 
Nas frases (817) a (825) temos os aspectos imperfectivo, cursivo, não acabado e durativo para a situação referencial, que nas frases (826) a (828) tem os aspectos perfectivo, acabado e durativo. A situação narrada em todas estas frases tem aspecto acabado.

Devido ao valor cessativo da perífrase nos pretéritos perfeito e mais-que-perfeito do indicativo, se o particípio indicar um estado que não pode cessar teremos uma frase ruim, inaceitável com estas formas. Veja exemplos (829) a (833).

829. * O filhote esteve nascido.

830. ?* O livro esteve lido durante um mês.

831. * A música esteve cantada.

832. * Os vinte quilômetros estiveram percorridos.

833. ?* A carne esteve cozida.

Uma outra particularidade desta perífrase no pretérito perfeito do indicativo, é que parece termos a possibilidade de ter frases que não têm aspecto acabado para a situação referencial como é o caso de (834) abaixo.

834. A porta esteve arrebentada todo esse tempo e só agora é que você notou?

Em (834) teríamos aspectos perfectivo, não acabado e durativo para a situação referencial, e acabado para a situação narrada (arrebentar). O não acabado, aqui, parece se dever ao fato de que o pretérito perfeito do indicativo estaria sendo usado pelo pretérito imperfeito do indicativo, o que equivale a dizer que (834) deveria ter a forma de (835).

835. A porta estava arrebentada todo esse tempo e só agora é que você notou?

Não encontramos nenhum outro exemplo semelhante a (834).

Para a perífrase "estar + particípio" valem as mesmas restrições de uso que colocamos para a perífrase "ter + objeto + particípio variável".

Castilho (1967), considerando o acabado da situação narrada, apresenta frases do tipo de (817), com o verbo no presente do indicativo, como tendo aspecto Perfectivo Resultativo, já que para ele o Perfectivo = acabado. Não concordamos com esta análise, pois ela não considera o estado, que é a situação referencial, e que, claramente, não é acabada. 
Como se pode observar, as perífrases de estar formam um sistema completo, para a indicação das fases de realização da situação expressa pelo principal que, em dois casos, representa a situação narrada:

$$
\begin{aligned}
& \text { estar }+ \text { por }+ \text { infinitivo } \\
& \text { não começado } \rightarrow \quad \text { estar }+ \text { para }+ \text { infinitivo } \\
& \text { estar }+ \text { em }+ \text { infinitivo } \\
& \text { Começado ou não acabado } \quad \rightarrow \quad \text { estar + gerúndio } \\
& \text { Acabado } \rightarrow \text { estar }+ \text { particípio }
\end{aligned}
$$

\section{4 - As PERÍFRASES DE IR}

\subsection{1 - IR + INFINITIVO}

A perífrase IR + INFINITIVO marca tempo futuro com todas as flexões temporais com que é possível. Vejamos alguns exemplos:

836. A execução vai sair às oito horas.

837. Ia chover por isso resolvi não sair.

838. Mesmo que a bomba vá explodir daqui a duas horas, é bom todos abandonarem a área imediatamente.

839. Se eu fosse convidar alguém, você seria o primeiro.

840. Quando eu for copiar o texto, faço as correções necessárias.

É comum, dependendo do significado do verbo principal ou do tempo em que está o verbo ir, termos não uma perífrase marcadora de futuridade, mas sim o verbo "ir", indicando locomoção para um lugar onde se realiza o indicado pelo verbo no infinitivo. Nos pretéritos perfeito e mais-que-perfeito do indicativo, isto ocorre sistematicamente (exemplos 842 a 845). Com estes dois tempos a perífrase só existe em orações temporais com a conjunção "quando" (exemplos 846 e 847). Com o pretérito mais-que-perfeito estas frases com a perífrase "ir + infinitivo" são estranhas ou ruins (exemplos 848 e 849).

841. Todo dia ia regar a horta para mim.

842. Maria foi tomar conta do bebê de Marina.

843. As meninas foram apanhar jabuticaba.

844. Quando cheguei à fazenda, José fora preparar canteiros para ajudar seu pai. 
845. Ontem fomos visitar meus tios.

846. Quando o filhote foi nascer, todos vieram ver.

847. Quando Madalena foi abrir a caixa, sua mãe a chamou.

848. ?* Quando eu fora pegar o livro, ele disse que não podia emprestá-lo.

849. * Quando eu fora escrever para você, me disseram que você havia mudado e não tínhamos seu novo endereço.

Nestas frases em que ir + infinitivo deixa de marcar tempo futuro, temos a expressão de aspectos devida à flexão temporal e a outros meios, como o adjunto adverbial. Assim, por exemplo, em (841), temos aspectos imperfectivo, não acabado e habitual devidos ao pretérito imperfeito do indicativo e à influência do adjunto adverbial "todo dia"; em (842), temos aspecto perfectivo devido ao pretérito perfeito do indicativo

Marcando o tempo futuro e impedindo a expressão do aspecto, esta perífrase parece anular qualquer diferença de significado entre frases como (850) e (851), em que a única diferença seria aspectual.

850. Quando eu ia falar ele chegou.

851. Quando eu fui falar ele chegou.

\subsection{2 - IR + GERÚNDIO}

A perífrase IR + GERÚNDIO marca o aspecto durativo com qualquer flexão verbal. Ela apresenta a situação como tendo desenvolvimento gradual, isto é, marca a ideia de progressividade. As demais noções aspectuais presentes nas frases com esta perífrase vão depender de outros fatores, tal como a flexão temporal. Vejamos alguns exemplos:

852. Os anos vão passando e não consigo encontrar um amor. (imperfectivo, cursivo, não acabado, durativo).

853. Vai chegando o momento em que todos saberão da verdade. (imperfectivo, cursivo, não acabado, durativo).

854. Pedro ia caminhando pelas ruas, enquanto pensava em seu problema. (imperfectivo, cursivo, não acabado, durativo).

855. João foi construindo a casa nas suas folgas. (perfectivo, durativo).

856. Lívio fora esquecendo os parentes, para não sofrer mais. (perfectivo, durativo).

857. Você irá catando o feijão para mim. (durativo). 
858. Se eu não pusesse esse adubo as folhas iriam amarelando e secariam.(durativo).

859. Embora vá engordando a olhos vistos, Pedro não quer fazer regime. (imperfectivo, cursivo, não acabado, durativo).

860. Mesmo que José fosse preparando a carne, o churrasco sairia atrasado. (durativo).

861. Se você for lendo durante a viagem, não aproveitará nada da paisagem. (durativo).

862. Foi muito bom ir comprando o material com antecedência. (durativo).

É frequente termos um habitual no lugar do durativo, normalmente por influência de elementos adverbiais (adjunto ou oração), como nos exemplos (863) e (864). Nestes casos, cada realização da situação habitual indicada pela perífrase é durativa.

863. Quando ele vem aqui, vai chegando perto dela até ficar juntinho. (imperfectivo, não acabado, habitual).

864. Ele sempre ia rodando até ficar tonto. (imperfectivo, não acabado, habitual).

No pretérito imperfeito do indicativo, esta perífrase pode ser usada para indicar que a situação esteve prestes a realizar-se, como podemos observar nos exemplos (865) a (867) abaixo. Neste caso, a perífrase fica com o mesmo valor futuro de IR + INFINITIVO (Cf. com o exemplo 850).

865. Eu ia contando a Pedro sobre a festa, quando mamãe fez um sinal para que eu me calasse.

866. André ia comprando o carro, mas Antônio lhe disse que ele tinha problemas no motor.

867. Quando ele ia cantando a música, as luzes se apagaram.

Com verbos de movimento, a frase com esta perífrase é ambígua. Numa interpretação temos a perífrase com seu valor durativo, principalmente se a frase pode ser usada numa descrição simultânea. Noutra interpretação a perífrase se desfaz: o verbo ir passa a indicar locomoção e o verbo no gerúndio, a forma de locomoção. Veja exemplos (868) e (869). Com a segunda interpretação o aspecto 
será o indicado pela flexão temporal: imperfectivo, habitual, não acabado para (868) e perfectivo para (869).

868. Antônio vai caminhando para a igreja.

869. Ele foi correndo para casa.

\section{5 - As PERÍFRASES DE VIR}

\subsection{1 - VIR + INFINITIVO}

A perífrase VIR + INFINITIVO não marca aspecto. Esta perífrase indica tempo futuro ${ }^{5}$, caso em que não haverá qualquer aspecto expresso. Nas frases em que há aspecto, este depende de fatores como a flexão temporal e/ou elementos adverbiais (orações ou adjuntos). Nestes casos a ideia de futuro desaparece. Exemplos:

870. José vem conversar com você sobre isto. (futuro).

871. José vem conversar comigo todos os dias (imperfectivo, não acabado, habitual) - Aspectos presentes pela influência do adjunto adverbial "todos os dias".

872. Rafael vinha morar conosco, mas desistiu. (futuro).

873. Os elefantes vinham morrer aqui, por isso há tantas ossadas. (imperfectivo, acabado, habitual) - Aspectos devidos à flexão temporal.

874. O rapaz veio buscar o livro. (perfectivo, acabado) - Aspectos devidos à flexão temporal.

875. Embora minha irmã venha cuidar das crianças quando preciso, não gosta muito de fazê-lo. (imperfectivo, não acabado, habitual) - Aspectos devidos à influência da oração subordinada adverbial temporal "quando preciso".

\subsection{2 - VIR + A + INFINITIVO}

A perífrase VIR + A + INFINITIVO também marca futuro, mas difere de "Vir + Infinitivo", porque indica um ponto terminal, representado pela realização da situação expressa pelo verbo no infinitivo. Este ponto terminal é visto como um resultado, uma consequência de outros fatores.

\footnotetext{
${ }^{5}$ Pontes (1973) também afirma que essa perífrase marca futuro. (PONTES, E. Verbos auxiliares em português. Petrópolis: Vozes, 1973. 145 p.).
} 
876. Se o rapaz vem a partir por causa do mal tratamento que vocês lhe dão, vocês ficarão em dificuldade.

877. É possível que algum dia venhamos a conversar com você.

878. Se ele viesse a morrer eu não me perdoaria nunca.

Naturalmente, esta perífrase não marca aspecto e, quando há aspecto na frase com ela formada, este se deve normalmente a fatores como a flexão temporal e/ou a influência de elementos adverbiais (adjuntos ou orações). Exemplos:

879. Roberto tanto procurou que veio a encontrar o que queria. (perfectivo, acabado) - Aspecto devido à flexão temporal.

880. As crianças insistiam, porque Mariana sempre vinha a atendê-las em seus desejos. (imperfectivo, habitual). - Aspecto devido à influência do Adjunto adverbial "sempre".

\subsection{3 - VIR + DE + INFINITIVO}

A perífrase VIR + DE + INFINITIVO marca o aspecto acabado para a situação expressa pelo verbo no infinitivo, com qualquer flexão temporal em que seja possível. Esta perífrase marca também passado recente e é muito pouco usada, pois os falantes preferem utilizar a perífrase ACABAR + DE + INFINITIVO que expressa as mesmas noções. ${ }^{6}$

É desnecessário dizer que muitas gramáticas condenam, como galicismo, o uso de VIR + DE + INFINITIVO.

Em muitos tempos flexionais as frases são estranhas ou inaceitáveis. Exemplos:

881. Venho de assistir a missa e não quero discutir com você.

882. Estou desesperado, pois venho de perder todos os meus documentos.

883. Mariana vinha de caminhar pelo bosque.

884. Se o menino viesse de engolir um alfinete estariam todos apavorados.

885. Embora ele venha de pintar a casa, não está sujo de tinta.

886. Vindo de colher os frutos, o sr. Jerônimo pediu seu pagamento.

${ }^{6}$ É desnecessário dizer que muitas gramáticas condenam, como galicismo, o uso de VIR $+\mathrm{DE}+\mathrm{IN}-$ FINITIVO. 


\subsection{4 - VIR + GERÚNDIO}

A perífrase VIR + GERÚNDIO marca os aspectos imperfectivo, cursivo, não acabado e durativo com todas as flexões temporais em que é possível, exceto com os pretéritos perfeito e mais-que-perfeito do indicativo em que os aspectos marcados são o perfectivo e o durativo. Veja os exemplos (887) a (897) abaixo.

887. Os rapazes vêm trabalhando sem muitas condições.

888. Maria vinha amando Aldo em silêncio, mas resolveu abrir o jogo.

889. Você viria duvidando de nós até hoje, se Carlos não tivesse contado a verdade.

890. Embora Sérgio venha construindo sua casa devagar ainda não interrompeu os trabalhos nem uma vez.

891. Se você viesse arquivando os papéis direito, não teríamos todo esse trabalho agora.

892. É Eossível que seu irmão venha ocultando alguma coisa de vocês.

893. Qual a razão de você vir guardando todos estes bilhetes?

894. Bernardo veio sendo feliz com a esposa, até começar a ter ciúmes.

895. César, viemos poupando você enquanto pudemos, mas agora temos de lhe dizer tudo.

896. O filhote viera nascendo com dificuldade, mas no final todos se alegraram, porque era um belo filhote.

897. Celene viera odiando o tio, até descobrir a realidade dos fatos.

Nos pretéritos perfeito e mais-que-perfeito do indicativo, temos aspecto acabado se algo assinala que a situação foi concluída (ver exemplos 894 e 897).

Devido ao sentido temporal da perífrase, que expressa um prolongamento da situação desde um ponto qualquer do passado até o presente (momento em que se fala) ou até um momento indicado do passado, não encontramos exemplos em que a perífrase fosse usada com os futuros do presente e do subjuntivo. Quando a perífrase é usada nestes tempos, perde em parte o valor aspectual acima especificado e indica iminência de ação (exemplo 898), o que não ocorre com frequência; ou a perífrase se desfaz e temos o verbo "vir" indicando movimento, e o verbo no gerúndio indicando o que se realiza ao mesmo tempo em que se vem. (exemplos 899 a 901).

898. Quando ele vier chegando em silêncio para nos surpreender, dar-lhe-emos o maior susto. 
899. João virá admirando a paisagem de lá até aqui.

900. Tenho certeza que você virá chateando mamãe durante a viagem.

901. Se ele vier catando frutinhas pelo mato, demorará mais de uma hora para chegar.

Observe-se que, em (898) a (901), o aspecto durativo está presente.

A interpretação que especificamos acima para as frases (899) a (901), aparece também com a perífrase nos pretéritos perfeito e mais-que-perfeito do indicativo, caso em que é comum as frases serem ambíguas. Exemplos:

902. Este menino veio fazendo perguntas durante toda a viagem.

903. Marina estava nervosa porque Cláudio viera catando tampinhas pela rua.

Se o verbo principal é de movimento, indica o modo de locomoção e não o que se faz concomitantemente à locomoção expressa pelo verbo vir. Com tais verbos as frases são ambíguas em todos os tempos, podendo ter a interpretação de locomoção + modo de locomoção ou uma interpretação com o valor aspectual da perífrase especificado no início deste item. ${ }^{7}$ Exemplo:

904. O guarda vem caminhando para cá.

Às vezes o todo da frase favorece uma ou outra interpretação. Exemplos:

905. Vim correndo para cá assim que recebi o recado. (A interpretação favorecida é a de locomoção + modo de locomoção).

906. O Juninho vem engatinhando há vários dias. (A interpretação favorecida é a imperfectiva, cursiva, durativa, não acabada).

Se o verbo principal é de evento, a frase só será aceitável com o valor aspectual cursivo e durativo, se puder ser usada numa descrição simultânea. (exemplos 907 e 908).

907. Ele vem chegando de mansinho para nos assustar.

908. Esta planta vinha morrendo por falta de rega.

${ }^{7}$ Ambiguidade semelhante foi observada para a perífrase ir + gerúndio (cf. item 8.4.2). 
Se o uso em descrição simultânea não for possível, a perífrase vir + gerúndio de verbo de evento formará frases que só serão aceitáveis se interpretadas como iterativas (exemplos 909 a 911). Em virtude disso, se o verbo de evento expressa situação que só se realiza uma vez para cada ser, a frase só será boa se o sujeito (quando o verbo é intransitivo) ou o objeto (quando o verbo é transitivo) for plural para possibilitar o valor iterativo (exemplos 912 a 915). Algumas vezes o sentido iterativo é reforçado ou marcado por um adjunto adverbial (exemplos 916 e 917).

909. Rafael vinha faltando ao trabalho sem explicar porque. (imperfectivo, não acabado, iterativo).

910. O rapaz vem partindo da Estação da Luz. (imperfectivo, não acabado, iterativo).

911. Seu filho vem pulando o muro ao invés de entrar pelo portão. (imperfectivo, não acabado, iterativo).

912. $\quad \mathrm{a}-* \mathrm{O}$ filhote vem nascendo sadio.

b - Os filhotes vêm nascendo sadios. (imperfectivo, não acabado, iterativo).

913. a - * A bomba vem explodindo há três dias.

b - As bombas vêm explodindo há três dias. (imperfectivo, não acabado, iterativo).

914. ? Josafá vem achando o livro. (Esta frase só é aceitável se imaginarmos que o livro é encontrado e perdido seguidamente).

915. a - * Este menino vem engolindo a bolinha de gude. (Esta frase só é admissível se imaginarmos uma situação em que a pessoa engole e expele a mesma coisa repetidas vezes).

b - Este menino vem engolindo bolinhas de gude. (imperfectivo, não acabado, iterativo).

916. O trem vem partindo às 5 horas. (imperfectivo, não acabado, iterativo).

917. Embora o Sr. José venha acordando às cinco horas todos os dias, só se levanta às sete. (imperfectivo, não acabado, iterativo).

\section{6 - AS PERÍFRASES ITERATIVAS E HABITUAIS}

\subsection{1 - ANDAR + GERÚNDIO}

A perífrase ANDAR + GERÚNDIO marca o aspecto iterativo com todas as flexões verbais em que é possível. Normalmente temos também o imperfectivo e o não acabado, exceto nos pretéritos perfeito e mais-que-perfeito do indicativo em que temos o perfectivo. Exemplos: 
918. Celina anda perguntando por você.

919. Os aviões andavam decolando sem permissão.

920. Se não fosse a vigilância constante, eles andariam roubando peças.

921. Mesmo que os rapazes andem acampando lá no vale, não vejo motivo para preocupação.

922. Se andássemos dançando tanto como o senhor diz, estaríamos mortos.

923. As sementes andarem brotando mais depressa é prova de que minha teoria está certa.

924. Se você andar comprando tolices, corto sua mesada.

925. Onofre andou perguntando por você.

926. Reginaldo andara testando um aparelho, sem permitir que alguém assistisse à experiência.

Com a perífrase no futuro do presente a maioria das frases é estranha ou ruim. Exemplos:

927. * O trem andará partindo atrasado, quando formos fazer a verificação.

928. * Andará chovendo no Rio, quando chegarmos lá.

Os falantes preferem usar a perífrase "estar + gerúndio" para expressar tais pensamentos. Entretanto é interessante observar que, se a frase com o verbo no futuro do presente for interrogativa, teremos um valor de presente hipotético, e a frase será perfeitamente aceitável e boa com os aspectos imperfectivo, não acabado e iterativo. Veja exemplos (929) a (931).

929. O trem andará partindo atrasado?

930. Andará chovendo no Rio?

931. Geraldo, andaremos ajudando quem não precisa?

Embora esta perífrase seja basicamente iterativa, em algumas frases parece que temos os aspectos cursivo e durativo em vez do iterativo. Isto parece ocorrer apenas com verbos indicadores de processos, principalmente com processos télicos que tenham objeto singular (exemplos 932 e 933); processos que não aceitam descontinuidade, tais como amar, viver, respirar, saber (= conhecimento) (exemplos 934 a 936) e verbos transformativos atélicos, desde que tenham sujeitos não agentivos 
(exemplos 937 e 938). O cursivo e o durativo aparecem com verbos de evento, apenas quando esses são tomados como processos e tendo objeto singular (exemplo 939).

932. Márcio anda emoldurando o quadro para você.

933. Jorge anda lendo o livro que lhe dei?

934. Pedro anda amando Maria. Qualquer um percebe isto.

935. Todos andavam vivendo com o mínimo necessário.

936. Marli anda sabendo isto muito bem e pode ajudar você.

937. Abílio anda engordando muito.

938. Bolivar anda enriquecendo a olhos vistos.

939. Os homens andam explodindo a ponte. (com sentido iterativo esta frase seria ruim. Ela só é aceitável com "explodir" significando o processo de preparação para a explosão).

Apesar dos aspectos cursivo e durativo, frases como (932) e (933) deixam entrever uma iteração na medida em que os processos de emoldurar e ler são realizados em períodos descontínuos sucessivos . Fica então a pergunta se aí temos realmente cursivo e durativo ou se o valor iterativo da perífrase se mantém. Para expressar a ideia contida nestas frases com o valor durativo e cursivo, o falante prefere, como mais natural, a perífrase "estar + gerúndio".

Se o verbo transformativo tiver sujeito agente e objeto plural teremos o iterativo (exemplo 940), mas se o objeto for singular (exemplo 941) teremos uma frase do tipo de (932) a (933).

940. Os falsários andam amarelando folhas para dizer que são antigas.

941. Marcos anda arredondando esta pedra para fazer um trabalho escolar.

Devido ao valor iterativo da perífrase, a frase será ruim quando tivermos um verbo de evento, indicador de situação que não se repete para o mesmo ser, com o sujeito (se o verbo é intransitivo) ou o objeto (se o verbo é transitivo) singular e de sentido não genérico. Exemplo:

942.* O bebê anda nascendo sadio.

O que comentamos para a perífrase "andar + gerúndio" vale também para a perífrase ANDAR + A + INFINITIVO. Esta perífrase, entretanto, é muito pouco 
usada no Brasil e, às vezes, as frases soam algo estranhas. Para exemplificação, basta substituir nos exemplos (918) a (942) o "gerúndio" por "a + infinitivo".

\section{6 .2 - VIVER + GERÚNDIO}

A perífrase VIVER + GERÚNDIO marca os aspectos imperfectivo, não acabado e habitual com todas as flexões verbais em que é possível. Exemplos.

943. Antônio vive protestando contra as injustiças dos homens.

944. Genivaldo vivia achando objetos na rua.

945. Pedrinho ainda viveria engolindo tudo o que achasse ser comestível, se não tivesse ficado com medo, depois que quase morreu envenenado.

946. Embora Dagoberto viva olhando para mim, nunca se aproximou.

947. Se Jane vivesse pintando como diz, teria muitos quadros prontos.

948. Você me impede de corrigi-lo agora, mas quando seu filho viver chegando tarde da noite, você irá se lamentar.

949. As meninas viverem caminhando pelo bosque é muito bom para a sua saúde.

Nos pretéritos perfeito e mais-que-perfeito do indicativo, a perífrase se desfaz e o que temos é o seguinte: o verbo viver em um destes tempos com seu significado de "ter vida", "passar a existência"; e o verbo no gerúndio indicando o modo como o sujeito viveu, ou a atividade que ele executou durante a vida. Veja exemplos (950) a (953).

950. Seu irmão viveu sonhando ser ator, mas nunca fez nada neste sentido.

951. Benedito viveu consertando móveis para as pessoas.

952. Selma vivera economizando para que depois os filhos esbanjassem tudo.

953. Ulisses vivera criando histórias que alegrassem as crianças.

No futuro do presente, as frases normalmente são ambíguas: temos uma interpretação habitual e outra interpretação de viver (= ter vida) + modo de viver ou atividade realizada durante a vida. A decisão entre uma e outra possibilidade parece que vai depender, em grande parte, do significado do verbo principal que favorecerá uma das duas interpretações. Veja exemplos abaixo. 
954. Você viverá pedindo esmolas. (ter vida + atividade).

955. Viveremos esperando que você volte. (ter vida + atividade).

956. Quando vier morar aqui, Valdete viverá caminhando pelos bosques a procura de plantas. (habitual).

Quando o sujeito da frase é algo que não pode "ter vida", a interpretação favorecida é a habitual, mas temos frases pouco naturais, provavelmente porque, quase nunca ou nunca, são utilizadas pelos falantes, apesar de possíveis (exemplo 957).

957. ? Viverão nascendo ervas daninhas no meu gramado.

Devido ao valor iterativo da perífrase, a frase será ruim, quando tivermos um verbo de evento, indicador de situação que não se repete para o mesmo ser, com o sujeito (se o verbo é intransitivo) ou o objeto (se o verbo é transitivo) singular e de sentido não genérico. Exemplos:

958. * $\quad *$ bezerrinho vive nascendo perfeito.

959. * O vaso vive quebrando. (Esta frase só seria possível se imaginássemos que o vaso se quebra e é consertado repetidas vezes).

O que comentamos para a perífrase "viver + gerúndio" vale também para a perífrase VIVER + A + INFINITIVO. Entretanto, como esta praticamente não é usada no Brasil, as frases soam um pouco estranhas. Para exemplificação, basta substituir nos exemplos (943) a (959) o "gerúndio" por “a + infinitivo".

\subsection{3 - VIVER + PARTICÍPIO}

A perífrase VIVER + PARTICÍPIO marca o aspecto habitual com todas as flexões verbais em que é possível. Marca os aspectos imperfectivo e não acabado com todos os tempos, exceto com os pretéritos perfeito e mais-que-perfeito do indicativo onde temos aspecto perfectivo.

Em realidade, nesta construção o particípio funciona como um adjetivo em função predicativa, e o verbo viver é um verbo relacional que marca a habitualidade pelo seu semantema. Compare-se para comprovação desta colocação exemplos como (960) e (961) abaixo.

960. João vive calado. (imperfectivo, não acabado, habitual).

961. João vive contente. (imperfectivo, não acabado, habitual). 
Vejamos alguns exemplos com a construção "viver + particípio".

962. Paulo vive perdido em fantasias. (imperfectivo, não acabado, habitual).

963. Esta porta vivia aberta quando a senhora não estava aqui. (imperfectivo, não acabado, habitual).

964. Antônio viveria aborrecido, se não tivesse aprendido a tratar com os problemas sem se envolver neles. (imperfectivo, não acabado, habitual).

965. Embora Alexandre viva rodeado de amigos, sente-se solitário. (imperfectivo, não acabado, habitual).

966. Se o menino vivesse queimado por causa de suas experiências, você poderia dizer alguma coisa. (imperfectivo, não acabado, habitual).

Muito frequentemente o verbo "viver" deixa de ter valor relacional e readquire seu valor nocional de "ter vida", "passar a vida" e o particípio, então, normalmente indica o modo de vida ou algo feito na vida ou num período dela. Isto acontece principalmente nos pretéritos perfeito e mais-que-perfeito do indicativo e no futuro do presente. Neste caso, o aspecto indicado é devido à flexão temporal do verbo viver, ou a algum outro fator, como adjuntos adverbiais. Muito frequentemente, as frases são ambíguas admitindo as duas interpretações. Exemplos:

967. Antônio viveu aborrecido com o mundo. (perfectivo, acabado).

968. José vivera preso às responsabilidades com a família para, no fim, receber ingratidão. (perfectivo, acabado).

969. Se você não fizer algo agora, viverá dominado por eles o resto de seus dias. (não aspecto).

970. Se você viver aborrecido com as coisas, o que ganhará com isso? (ambígua).

971. Vivendo calado desse jeito você deixa todos preocupados. (ambígua. A tendência é para interpretar viver $=$ ter vida).

No futuro do presente, se a frase é interrogativa, temos sentido presente e os aspectos expressos são o imperfectivo, o não acabado e o habitual. Exemplo: 
972. Antônio viverá calado, porque não concorda com nossas ideias?

Considerando que "viver" é um verbo relacional e o "particípio" funciona como adjetivo, quando "viver + particípio" marca o aspecto habitual, e que, nas construções de "viver + adjetivo", também temos o habitual; podemos afirmar que o verbo "viver", pelo seu semantema, marca o habitual para os estados.

\subsection{4 - COSTUMAR + INFINITIVO}

A perífrase COSTUMAR + INFINITIVO marca o aspecto habitual com todas as flexões verbais em que é possível. Os demais aspectos presentes na frase são devidos à flexão temporal e outros fatores. Vejamos alguns exemplos:

973. O supermercado costuma abrir antes das oito horas. (imperfectivo, não acabado, habitual).

974. Terezinha costumava pregar os botões para mim, quando eu morava em São Paulo. (imperfectivo, não acabado, habitual).

975. Papai costumará chegar às oito horas, depois que passar para o novo trabalho. (habitual).

976. Fausto costumaria fechar a porta se não tivesse você para fazê-lo. (imperfectivo, não acabado, habitual).

977. Embora costume consertar carros rapidamente, Tininho não aprontou o meu a tempo. (imperfectivo, não acabado, habitual).

978. Se seu filho costumasse vir aqui, eu lhe diria. (imperfectivo, não acabado, habitual).

979. Quando os homens costumarem morrer por um ideal, teremos mais fé neste mundo. (habitual).

980. Se aqui costumar chover muito, vou adorar este lugar. (imperfectivo, não acabado, habitual).

981. Os soldados costumarem explodir as pontes para evitar o avanço do inimigo, nem sempre é uma boa tática. (habitual).

982. Costumando pagar suas promessas, Cláudia não pensou que alguém pudesse faltar com a palavra. (habitual).

Nos pretéritos perfeito e mais-que-perfeito do indicativo, sistematicamente, e no futuro do presente com bastante frequência, as frases são ambíguas e podem ter duas interpretações. A primeira, própria da perífrase, de que a pessoa teve ou terá o costume de fazer algo. Neste caso, teremos, com os pretéritos os aspectos perfectivo, acabado e habitual e, com o futuro do presente, apenas o habitual. Na 
segunda interpretação, temos o significado de que a pessoa "acostumou-se" ou "se acostumará" a fazer algo. Aqui teremos o aspecto devido à flexão temporal: perfectivo e acabado (com os pretéritos) e não aspecto (com o futuro). Nesta segunda interpretação, parece-nos que temos não o verbo "costumar", mas uma forma dialetal popular de "acostumar-se" com o /o/ pretônico pronunciado como [u], que é usada também em outros tempos, como o presente do indicativo (exemplo 990). Observe-se a ambiguidade a que nos referimos nos exemplos (983) a (990) abaixo.

983. O Sr. José costumou levantar cedo.

984. Papai costumou comprar neste supermercado.

985. Celina costumou ficar na sala depois do almoço.

986. O trem costumara sair no horário.

987. O menino costumara pedir balas ao avô.

988. As pessoas costumarão respirar corretamente.

989. Sérgio costumará limpar os pés antes de entrar.

990. Não se preocupe, com o tempo ela costuma morar aqui.

Nos pretéritos perfeito e mais-que-perfeito, devido ao pouco ou nenhum uso de tais formas, para indicar um hábito acabado, há uma tendência para considerar mais a interpretação de "acostumar-se". Se colocamos um adjunto adverbial como "sempre" nas frases com estes tempos, temos o aspecto habitual sem dúvida (exemplos 991 a e 992 a). Neste caso, entretanto, o aspecto é marcado pelo adjunto adverbial, e o verbo costumar é perfeitamente dispensável na expressão do pensamento em questão (exemplos 991 b e 992 b).

991. a - O trem sempre costumou partir no horário.

b - O trem sempre partiu no horário.

992. a - Eunice sempre costumou resfriar-se, quando tomava sereno.

b - Eunice sempre se resfriou, quando tomava sereno.

8.6.5 - USAR + INFINITIVO

A perífrase USAR + INFINITIVO marca o aspecto habitual com todas as flexões verbais, conforme se pode observar nos exemplos abaixo. Os demais aspectos presentes na frase são devidos a outros fatores, principalmente à flexão temporal.

993. Mamãe usa limpar a casa de tarde. (imperfectivo, não acabado, habitual). 
994. Madalena usava colocar uma flor sobre sua mesa do escritório. (imperfectivo, habitual).

995. Os homens já usaram beijar as mãos às senhoras. (perfectivo, acabado, habitual).

996. Depois deste problema, ele usará conferir todas as listas de mercadorias. (habitual).

997. Se eu não tivesse tanto trabalho usaria tirar uma soneca depois do almoço. (habitual).

998. Embora ele use avisar que vai chegar mais tarde, sempre fico preocupada. (imperfectivo, não acabado, habitual).

999. Mesmo que Álvaro usasse levar salgados do bar para os filhos, vocês não tinham nada com isso. (imperfectivo, não acabado, habitual).

1.000. Usar trancar a porta ao sair é uma boa coisa. (habitual).

Esta perífrase, que a nosso ver tem o mesmo significado de "costumar + infinitivo", é pouco usada.

\subsection{6 - HABITUAR-SE + A + INFINITIVO}

A perífrase HABITUAR-SE + A + INFINITIVO, a nosso ver não marca qualquer aspecto.

Castilho (1967, p.94) afirma que esta perífrase, com verbos atélicos, expressa o aspecto Iterativo Imperfectivo e apresenta apenas um exemplo que transcrevemos abaixo, sob o número (1.001).

\subsection{1. "Habituou-se a estudar pela manhã."}

O verbo "habituar-se" significa "adquirir o hábito de...". Possivelmente por extrapolação, o autor deve ter concluído que, se adquiriu o hábito de estudar pela manhã, então a situação de "estudar pela manhã" se repete e temos a iteratividade. Esse tipo de raciocínio, entretanto, não deve ser feito, pois a construção em si não marca a iteratividade gramaticalmente, com referência explícita à repetição da situação, atribuindo-lhe uma duração descontínua, embora logicamente saibamos que se o hábito foi criado a situação se repetirá.

Os aspectos que aparecem em frases com esta perífrase não se devem a ela, mas a outros meio de expressão do aspecto, como as flexões temporais e adjuntos adverbiais. Veja os exemplos (1.002) a (1.004). 
1.002. Eles reclamam, mas sempre se habituam a obedecer o regulamento. (imperfectivo, não acabado, habitual) - O aspeto é devido ao presente do indicativo e ao adjunto adverbial "sempre".

1.003. Quando estive lá, Waldemar habituava-se a engolir apenas depois de mastigar trinta vezes a porção de alimento. (imperfectivo, cursivo, não acabado, durativo) - $\mathrm{O}$ aspecto é devido ao pretérito imperfeito do indicativo

1.004. Cristina habituou-se a tomar leite antes de dormir. (perfectivo, acabado) - $\mathrm{O}$ aspecto é devido ao pretérito perfeito do indicativo

\subsection{7 - TORNAR/VOLTAR + A + INFINITIVO}

Poder-se-ia pensar que as perífrases TORNAR + A + INFINITIVO e VOLTAR $+\mathrm{A}+$ INFINITIVO marcassem o aspecto iterativo, uma vez que expressam, respectivamente o fato de uma situação ter uma segunda realização, ou passar a ser realizada outra vez após um período de interrupção. Estas perífrases, entretanto, não marcam aspecto iterativo, porque, apesar de haver repetição da situação, elas se referem apenas a uma realização da situação e, portanto, não lhe atribuem uma duração descontínua.

$\mathrm{O}$ aspecto presente em frases construídas com estas perífrases não se deve a elas, mas normalmente à flexão temporal e a elementos adverbiais (adjuntos ou orações). Geralmente temos os aspectos imperfectivo, não acabado e habitual nos presentes e nos pretéritos imperfeitos do indicativo e do subjuntivo por influência de adjuntos ou orações adverbiais e o perfectivo nos pretéritos perfeito e maisque-perfeito do indicativo. Veja exemplos (1.005) a (1.010).

1.005. Quando Antônio está na cidade Raul volta a chegar tarde em casa.

1.006. Célia fazia regime, mas sempre tornava a engordar.

1.007. Embora Paulo torne a adoecer cada vez que bebe, não se decide a deixar este vício.

1.008. Todo ano você volta a estudar e desiste no meio do período.

1.009. Tornou a chover de tarde.

1.010. Quando cheguei da viagem, meu irmão voltara a trabalhar.

\section{7 - As PERÍFRASES DE FICAR}

No estudo da expressão do aspecto pelas perífrases de ficar, é preciso considerar três possibilidades de significado ou emprego deste verbo, pois o aspecto 
expresso irá variar de acordo com o significado ou emprego em que ele se apresenta. Estas três possibilidades são:

1. O verbo ficar significa "permanecer ou conservar-se em determinada situação";

2. O verbo ficar significa "tornar-se", "vir a estar em determinada situação" (geralmente um estado);

3. O verbo ficar, na condição de auxiliar, marca a iteração da situação.

Quando o verbo "ficar" se apresenta com o primeiro significado, a perífrase marca o aspecto durativo principalmente se temos explícito, na frase ou no contexto, o período de tempo em que se permaneceu ou permanecerá na situação indicada. $\mathrm{O}$ verbo ficar pode ocorrer com o primeiro sentido nas perífrases FICAR + GERÚNDIO (cf. exemplos 1011 a 1015), FICAR + PARTICÍPIO (cf. exemplos 1.016 a 1.019$)$.

1.011. Você fica olhando as crianças, enquanto eu vou fazer compras.

1.012. André ficará orientando as pessoas que chegam.

1.013. É preciso que você o fique esperando aqui.

1.014. Se eu ficar assistindo televisão até tarde hoje, não levantarei cedo amanhã para ir à escola.

1.015. Dagoberto ficou estudando a noite toda. (perfectivo, durativo).

1.016. Não gosto quando você fica calado, olhando para mim.

1.017. Selma ficou parada na porta até que a notassem.

1.018. Prometo-lhe que ficarei sentada durante o espetáculo.

1.019. César queria que eu ficasse escondido aqui, ouvindo o que as pessoas diziam.

Na perífrase "ficar + particípio", o particípio vale por um adjetivo e o verbo ficar funciona como verbo relacional exatamente como em construções do tipo "ficar + adjetivo".

No pretérito imperfeito do indicativo, parece que só obtemos frases com valor iterativo ou habitual.

Quando o verbo "ficar" tem o primeiro significado, a presença de elementos adverbiais temporais (adjuntos ou orações) ou de frequência, normalmente leva à expressão do habitual. Nestes casos, a situação que se repete é vista como durativa. Veja exemplos (1.020 a 1.023). 
1.020. Todos os dias ele fica esperando a filha na porta da escola.

1.021. Jorge sempre fica calado durante as reuniões e depois diz que não o deixamos opinar.

1.022. Embora Celina fique ouvindo quando falo com ela, nunca me atende.

1.023. O fato de eu ficar ajoelhado quando rezo, pareceu-lhes estranho.

Na perífrase FICAR + POR + INFINITIVO, o verbo ficar parece apresentar sempre o primeiro sentido (conservar-se em determinada situação). "Por + infinitivo" expressa um estado que representará uma situação referencial. Esta perífrase, com o significado especificado, marca o aspecto durativo (exemplos 1.024 a 1.027), ou o habitual com o auxílio de elementos adverbiais (exemplos 1.028 a 1.030) para a situação referencial, nas mesmas condições especificadas acima para "ficar + gerúndio ou particípio". A situação narrada é sempre marcada pelo conjunto "por + infinitivo", como não começada.

1.024. Este livo fica por ler até que eu tenha tempo para isto.

1.025. É bom que este caso fique por resolver, enquanto não temos melhores provas.

1.026. Seu processo ficará por despachar até que você traga o documento que falta.

1.027. Esta mesa ficou por arrumar a semana toda. (perfectivo, durativo).

1.028. Quando o serviço é muito a lista dos pagamentos fica por conferir. (habitual).

1.029. Embora o relatório fique por bater todo sábado, o presidente nunca deixou de recebê-lo na segunda à tarde.

1.030. Esta questão sempre ficou por decidir, mas hoje temos de encará-la.

Quando não se especifica de alguma forma, na frase ou no contexto, o período de permanência na situação, temos a implicação lógica de que o que "ficou ou ficará por fazer" "estava ou está por fazer”. Esta implicação leva a interpretar o verbo "ficar" como equivalente a "continuar" o que pode nos levar a uma análise aspectual semelhante à que temos para "continuar + por + fazer" (cf. item 8.9). As frases (1.031) a (1.033) são exemplos do que acabamos de dizer.

1.031. Se você demorar muito, estes caixotes ficam por fechar. (S.R.: estado de "por fechar" - começado; S.N.: fechar - não começado). 
1.032. Como não tive tempo, este livro ficou por ler. (S.R.: estado de "por ler": perfectivo; S.N.: ler - não começado).

1.033. Seu quarto ficará por limpar, se você não vier me ajudar. (S.R.: estado de "por limpar": começado; S.N.: limpar - não começado).

Quando o verbo "ficar" apresenta o segundo significado (tornar-se, vir a estar em determinada situação), o aspecto indicado nada tem a ver com a perífrase em si, mas se deve à flexão temporal e à influência de outros elementos, principalmente os adjuntos e orações adverbiais de tempo. O verbo ficar apresenta este segundo sentido quase só na perífrase FICAR + PARTICÍPIO. Veja os exemplos (1.034) a (1.038).

1.034. Meu cachorro fica apavorado quando ouve os estouros dos fogos de artifício. (imperfectivo, não acabado, habitual) - Aspecto devido ao presente do indicativo e à influência da oração adverbial temporal.

1.035. Margarete sempre ficava desnorteada com as brigas dos filhos. (imperfectivo, não acabado, habitual) - Aspecto devido ao pretérito imperfeito do indicativo e ao adjunto adverbial "sempre".

1.036. O documento ficou rasgado em pedacinhos. (perfectivo, acabado) - Aspecto devido ao pretérito perfeito do indicativo.

1.037. Este elemento ficará prensado entre as duas chapas de metal. (não aspecto) - Devido ao tempo futuro.

1.038. Embora minha mãe fique preocupada quando demoramos muito, Renato nunca se dá ao trabalho de telefonar avisando. (imperfectivo, não acabado, habitual) - Aspecto devido ao presente do subjuntivo com valor temporal de presente e à influência da oração temporal.

Nos presentes e pretéritos imperfeitos do indicativo e do subjuntivo há uma tendência para o habitual. O durativo e cursivo, nestes tempos, só parecem ocorrer (quando o verbo ficar tem o segundo sentido), quando se tem a combinação de "estar + gerúndio" e "ficar + particípio" (ver exemplo 1039).

1.039. O rapaz está ficando apavorado com estas ameaças. (imperfectivo, cursivo, não acabado, durativo).

Excetuada a perífrase "ficar + particípio", o verbo ficar só aparece com o segundo significado na perífrase "ficar + gerúndio", quando o verbo principal é um verbo estático não de estado como nas frases (1040) e (1041). 
1.040. Arquibaldo ficou sabendo de tudo. (perfectivo, acabado) - Aspecto devido ao pretérito perfeito do indicativo

1.041. Se você fizer isto, o inimigo fica tendo uma vantagem sobre nós. (não aspecto) - Porque o presente do indicativo tem valor de futuro.

$\mathrm{O}$ verbo ficar tem o terceiro significado apenas com a perífrase FICAR + GERÚNDIO que, neste caso, marca o aspecto iterativo com qualquer flexão temporal em que seja possível. Veja exemplos (1.042) a (1.048) abaixo.

1.042. Você fica falando isto que acabará tendo problemas. (imperfectivo, não acabado, iterativo).

1.043. Você ficava telefonando para o pensionato, mesmo depois que lhe pedi para não fazê-lo. (imperfectivo, não acabado, iterativo).

1.044. Celso ficou escrevendo para a revista até lhe darem uma resposta. (perfectivo, iterativo).

1.045. Se o gerente não recebê-lo, ele ficará vindo aqui e insistindo. (iterativo).

1.046. Embora Roberto fique me olhando, nunca me dirigiu a palavra. (imperfectivo, não acabado, iterativo).

1.047. Embora ele ficasse pedindo para eu ajudá-lo, nunca o achei chato. (imperfectivo, não acabado, iterativo).

1.048. Se você ficar indo à beira do rio, nunca mais deixo você passear na fazenda. (iterativo).

Com os verbos de evento a perífrase ficar + gerúndio normalmente tem valor iterativo (cf. exemplos 1.049 e 1.050).

1.049. Por que você fica partindo sem avisar? (imperfectivo, acabado, iterativo).

1.050. Você ficou chegando atrasado até que o despediram. (perfectivo, iterativo).

A perífrase FICAR + A + INFINITIVO, que é pouco usada, se comporta exatamente como a perífrase "ficar + gerúndio" em todos os casos.

$\mathrm{O}$ verbo ficar quando funcionando como relacional em construções do tipo "ficar + atributo" se comporta, em todos os casos, exatamente como em "ficar + particípio", onde o particípio sempre tem valor de adjetivo. 
Os diferentes valores das perífrases de ficar nem sempre são claramente distinguíveis e, muitas vezes, a frase parece ambígua.

\section{8 - AS PERÍFRASES DE PERMANECER}

As perífrases PERMANECER + GERÚNDIO e PERMANECER + PARTICÍPIO têm valores aspectuais diversos conforme o verbo permanecer signifique: 1) conservar-se; 2 ) continuar a...

Se o verbo permanecer tem o sentido de "conservar-se", a perífrase expressa o aspecto durativo, principalmente se temos explícito na frase ou no contexto o período de tempo em que se permaneceu na situação indicada. Veja os exemplos (1051) a (1058) abaixo.

1.051. O presidente da Câmara permanece falando há mais de uma hora. (imperfectivo, não acabado, durativo).

1.052. Este homem permaneceu governando o país por duas décadas. (perfectivo, acabado, durativo).

1.053. Meu filho permanecerá atendendo os compradores por duas horas, depois um de vocês o substituirá. (durativo).

1.054. É indispensável que você permaneça vigiando a noite toda. (durativo).

1.055. Desde ontem ele permanece sentado ali. (imperfectivo, não acabado, durativo).

1.056. Jair permaneceu calado durante a festa. (perfectivo, durativo).

1.057. Você permanecerá montado neste cavalete, enquanto durar o primeiro ato. (durativo).

1.058. Se Aurélio permanecesse escondido por uns dois anos, talvez as pessoas se esquecessem dele. (durativo).

Se o verbo permanecer tem o sentido de "continuar a...", temos o aspecto começado ou não acabado para a situação referida pelo gerúndio ou particípio, quer ela seja vista como referencial quer seja vista como narrada. Ex.:

1.059. Este grande atleta permanece competindo até hoje. (imperfectivo, cursivo, não acabado, durativo).

1.060. O menino João Carlos permanece desaparecido até hoje. (imperfectivo, cursivo, não acabado, durativo).

1.061. O candidato permaneceu expondo seus planos, apesar da reação do povo. 
a - S.R.: permanecer expondo - perfectivo, acabado.

b - S.N.: expor - não acabado.

1.062. Plínio permaneceu calado, embora todos insistissem para que ele dissesse o que havia acontecido.

a - S.R.: permanecer calado - perfectivo, acabado.

b - S.N.: estado de calado - não acabado.

1.063. Egberto permanecerá tocando, quando começarmos a distribuir o folheto com a letra da música. (começado).

Como se pode observar nos exemplos dados, os dois valores de permanecer nem sempre são claramente separáveis, o que dificulta a análise em muitos casos.

Por influência de elementos adverbiais (adjuntos ou orações), temos o habitual com as perífrases de permanecer. Neste caso, cada realização da situação é vista como durativa ou simplesmente começada conforme o caso. Exemplos:

1.064. Romeu sempre permanece calado durante as reuniões. (imperfectivo, não acabado, habitual) - Cada realização da situação é durativa.

1.065. Quando havia muito serviço Valério permanecia emoldurando quadros até mais tarde. (imperfectivo, não acabado, habitual) Cada realização da situação é começada e durativa.

1.066. Embora Dirce e Raul permaneçam conversando muito tempo quando se encontram, não são grandes amigos. (imperfectivo, não acabado, habitual) - Cada realização da situação é durativa.

A perífrase PERMANECER + A + INFINITIVO, menos usada que "permanecer + gerúndio", se comporta exatamente como esta no que diz respeito à expressão do aspecto. $\mathrm{O}$ verbo permanecer, usado como relacional em construções do tipo "permanecer + atributo", se comporta exatamente como na perífrase "permanecer + particípio" (onde particípio tem valor de um adjetivo) no que respeita à expressão do aspecto.

As frases com as perífrases de permanecer são pouco frequentes, uma vez que os falantes preferem expor os mesmos pensamentos valendo-se das perífrases de estar, ficar e continuar.

\section{9 - As PERÍfrASES DE CONTINUAR, PROSSEGUIR E SEGUIR}

As perífrases que têm continuar e prosseguir como auxiliares marcam os aspectos começado ou não acabado e durativo para a situação expressa pelo verbo 
principal, quer ela seja vista como situação narrada, quer seja vista como situação referencial, com qualquer flexão verbal. Como aspecto durativo + evento $=$ iteratividade; quando temos estas condições, em vez do durativo temos o iterativo.

Vejamos alguns exemplos para cada perífrase.

\subsection{1 - CONTINUAR + GERÚNDIO}

1.067. Continuamos estudando comunicação. (imperfectivo, cursivo, não acabado, durativo).

1.068. Apesar dos avisos, Ricardo continuava chegando atrasado. (imperfectivo, não acabado, iterativo).

1.069. Os ônibus continuarão partindo às 6 horas. (imperfectivo, começado, iterativo).

1.070. Continue fazendo o exercício. (imperfectivo, cursivo, começado, durativo).

1.071. Rafael continuou procurando o documento embora eu the tivesse dito que podia deixar aquilo de lado.

a) S.R.: continuar procurando - perfectivo, acabado.

b) S.N.: procurar - não acabado, durativo.

1.072. Embora Marcos continuasse amando Marina, resolveu não procurá-la mais. (imperfectivo, cursivo, não acabado, durativo).

A perífrase CONTINUAR $+\mathrm{A}+$ INFINITIVO, que é muito pouco usada, tem o mesmo valor que "continuar + gerúndio". Para exemplificação, basta substituir nas frases (1.067) a (1.072) o gerúndio por "a + infinitivo".

\subsection{2 - CONTINUAR + PARTICÍPIO}

1.073. Meu cachorro continua desaparecido. (imperfectivo, cursivo, não acabado, durativo).

1.074. Quando voltei, o menino continuava acordado. (imperfectivo, cursivo, não acabado, durativo).

1.075. Eu chamei José às seis horas, mas ele continuou deitado.

a) S.R.: continuar deitado - perfectivo.

b) S.N.: estado de deitado - não acabado, durativo.

1.076. Embora a exibição deste filme continue proibida, vão exibi-lo para os alunos do curso de artes. (imperfectivo, cursivo, não acabado, durativo). 
1.077. Paulo disse que continuará escondido até que tudo se acalme. (imperfectivo, cursivo, não acabado, durativo).

Como o particípio sempre indica um estado, a perífrase "continuar + particípio" não aceita a interpretação iterativa.

Quando utilizado como verbo relacional, em construções do tipo "continuar + atributo", o verbo continuar expressa os aspectos não acabado e durativo, da mesma forma que na perífrase "continuar + particípio" onde o particípio tem sempre um valor adjetivo.

\subsection{3 - CONTINUAR + POR + INFINITIVO}

Nesta perífrase, além dos aspectos já especificados acima, teremos sempre o aspecto não começado para a situação narrada, que é a situação expressa pelo verbo no infinitivo. Também aqui "POR + INFINITIVO" tem valor adjetivo, indicando o estado de algo antes da realização da situação expressa pelo infinitivo. Por esta razão, não temos a interpretação iterativa também com esta perífrase.

1.078. Seu vestido continua por arrematar, pois não tive tempo.

a) S.R.: Estado de "por arrematar" - imperfectivo, cursivo, não acabado, durativo.

b) S.N.: arrematar - não começado.

1.079. Os móveis continuavam por envernizar, quando fui lá hoje cedo. a) S.R.: estado de "por envernizar" - imperfectivo, cursivo, não acabado, durativo.

b) S.N.: envernizar - não começado.

1.080. Esta máquina continuará por consertar até que você me pague o conserto das outras.

a) S.R.: estado de "por consertar": imperfectivo, cursivo, não acabado, durativo.

b) S.N.: consertar - não começado.

1.081. Embora a casa continue por pintar já fizemos vários arranjos.

a) S.R.: estado de "por pintar" - imperfectivo, cursivo, não acabado, durativo.

b) S.N.: pintar - não começado.

Quando essa perífrase é usada nos pretéritos perfeito e mais-que-perfeito do indicativo, temos um caso bastante particular, porque há referência a três situações 
ao mesmo tempo: a) a situação de "continuar + por + infinitivo" (situação referencial); b) a situação que é o estado indicado em "por + infinitivo" (situação narrada 1); c) a situação expressa pelo "infinitivo" (situação narrada 2). Veja exemplos 1082 e 1083. Nos demais tempos (cf. exemplos 1078 a 1081), não há razão para distinção entre a situação narrada 1 e a referencial, porque elas são simultâneas.

1.082. Apesar da ordem do chefe, o arquivo continuou por organizar.

a) S.R.: continuar por organizar - perfectivo, acabado.

b) S.N.1: estado de "por organizar" - não acabado, durativo.

c) S.N.2: organizar - não começado.

1.083. Mesmo depois de obtida a verba, o ginásio continuou por construir, por causa de divergências entre os diretores.

a) S.R.: continuar por construir - perfectivo, acabado.

b) S.N.1: estado de "por construir" - não acabado, durativo.

c) S.N.2: construir - não começado.

\subsection{4 - PROSSEGUIR + GERÚNDIO}

1.084. Os peixes de lagoa prosseguem morrendo sem que nada seja feito. (imperfectivo, cursivo, não acabado, durativo).

1.085. Os homens prosseguirão cavando noite adentro, para que tudo seja preparado a tempo. (imperfectivo, cursivo, não acabado, durativo).

1.086. Embora prossiga chovendo aqui em Minas, as chuvas já se tornaram mais leves e sem ventos fortes. (imperfectivo, cursivo, não acabado, durativo).

1.087. Como todos pediram, o conferencista prosseguiu falando apesar da hora avançada.

a) S.R.: prosseguir falando - perfectivo, acabado.

b) S.N.: falar - não acabado, durativo.

A perífrase "prosseguir + gerúndio" é bem menos usada que "continuar + gerúndio" e parece não ocorrer com a interpretação iterativa.

\subsection{5 - SEGUIR + GERÚNDIO OU A + INFINITIVO}

As perífrases de "seguir" são muito pouco usadas, particularmente "seguir $+\mathrm{a}+$ infinitivo". 
Estas perífrases só marcam os aspectos durativo e começado ou não acabado, quando "seguir" tem o significado de "continuar" (cf. exemplos 1.088 a 1.090). Se seguir não se apresenta com este significado, a frase é interpretada como indicando: a) a situação que será realizada em seguimento a outra explícita ou não; b) que algo ou alguém irá para algum lugar, fazendo alguma coisa ou irá de um determinado modo. Neste caso, o aspecto depende da flexão temporal e outros fatores.

1.088. Raquel segue engordando apesar do regime que está fazendo. (imperfectivo, cursivo, não acabado, durativo).

1.089. Não importa o que digam, seguirei odiando você até o fim da minha vida. (imperfectivo, cursivo, começado, durativo).

1.090. É importante que você siga vigiando-o para mim. (imperfectivo, cursivo, começado, durativo).

Normalmente o falante usa pouco esta perífrase por preferir as de "continuar" e "ficar".

É interessante notar que, por causa do significado das perífrases de continuar, prosseguir e seguir, quando elas têm sentido futuro há uma ligação presente ${ }^{\circledR}$ futuro.

É frequente termos com estas perífrases frases de sentido habitual, por influência de elementos adverbiais (adjuntos e orações). Isto ocorre principalmente nos presentes e pretéritos imperfeitos do indicativo e do subjuntivo. Nestes casos, cada realização da situação é vista como começada e durativa. Veja exemplos (1.091) a (1.095).

1.091. Quando há muito serviço, Alberto continua conferindo as notas depois do expediente. (imperfectivo, não acabado, habitual).

1.092. Quando eu entrava na biblioteca, ele prosseguia lendo, como se ninguém tivesse entrado ali. (imperfectivo, não acabado, habitual).

1.093. Embora Joana sempre continuasse trabalhando após o expediente, para que nada ficasse atrasado, o chefe nunca lhe agradeceu a boa vontade. (imperfectivo, não acabado, habitual).

1.094. Embora todos os dias os rapazes prossigam nadando após a aula, o diretor do clube não acha ruim. (imperfectivo, não acabado, habitual).

1.095. Quando vou visitá-lo na clínica, ele segue falando sozinho como se nem tivesse percebido minha presença. (imperfectivo, não acabado, habitual). 
As perífrases de continuar, prosseguir e seguir, principalmente as de continuar, deixam claro que uma situação que já estava em realização antes de um dado momento não foi interrompida como se esperava.

\subsection{0 - As PERÍFRASES DE DEIXAR}

\subsection{1 - DEIXAR + GERÚNDIO/DEIXAR + A + INFINITIVO/DEIXAR + INFINITIVO}

As perífrases DEIXAR + GERÚNDIO, DEIXAR + A + INFINITIVO e DEIXAR + INFINITIVO não marcam qualquer aspecto.

Nas duas primeiras (deixar + gerúndio ou $+\mathrm{a}+$ infinitivo), não temos em realidade uma perífrase, mas o verbo "deixar" indicando que alguém se afasta (fisicamente ou não) de outro ser que permanece realizando uma situação indicada pelo "gerúndio" ou "a + infinitivo". O verbo "deixar" terá o aspecto devido à flexão verbal e/ou a outros fatores, enquanto a situação expressa pela forma nominal será sempre apresentada como imperfectiva, cursiva, começada ou não acabada e durativa (cf. exemplos 1.096 a 1.099). Em "deixar + infinitivo", deixar significa que se consente, que se permite, que não se coloca obstáculo à realização da situação expressa pelo infinitivo. Aqui também, deixar tem o aspecto devido à flexão verbal e/ou outros fatores enquanto a situação expressa pelo infinitivo não tem aspecto atualizado. Veja os exemplos (1.100) e (1.101). Nos exemplos (1.096) a (1.101) abaixo, os aspectos indicados entre parênteses são do verbo deixar.

1.096. Eleuza sempre me deixa assistindo televisão e vai dormir. (imperfectivo, não acabado, habitual) - Aspecto devido ao presente do indicativo e ao adjunto adverbial sempre. Em cada realização da situação "assistindo" tem o aspecto que indicamos acima.

1.097. Antônio deixou-a limpando a casa e foi ao supermercado. (perfectivo) - Aspecto devido ao pretérito perfeito do indicativo.

1.098. Talvez eu o deixe dormindo e venha visitar você. (não aspecto por causa do presente do subjuntivo com sentido futuro).

1.099. Antônio deixa a massa a endurecer e vai preparar as tintas.

A interpretação mais natural para (1.099) é com os aspectos imperfectivo, não acabado, habitual, mas se usada numa descrição simultânea terá uma interpretação com os aspectos perfectivo e pontual. 
1.100. Seu pai deixou você ir a Caldas Novas? (Perfectivo) - Aspecto devido ao pretérito perfeito do indicativo.

1.101. O chefe não nos deixará sair mais cedo. - (não aspecto devido ao futuro do presente).

\subsection{2 - DEIXAR + DE + INFINITIVO}

A perífrase DEIXAR + DE + INFINITIVO, em si, não marca qualquer aspecto. Ela indica que uma situação que estava em realização foi interrompida, ou que não se realizou ou realizará uma situação que deveria ser realizada. $\mathrm{O}$ aspecto que temos em frases com esta perífrase se deve a outros meios de expressão, tais como a flexão verbal e elementos adverbiais (exemplos 1.102 a 1.107).

1.102. Quando está muito cansada, Marina deixa de datilografar e vai fazer outro tipo de trabalho. (imperfectivo, não acabado, habitual) - Aspecto devido ao presente do indicativo e à influência da oração adverbial.

1.103. Quando você deixará de amolar minha paciência? (não aspecto por causa do futuro do presente).

1.104. Marivaldo deixava de assinar o ponto todos os dias. (imperfectivo, não acabado, habitual) - Aspecto devido ao pretérito imperfeito do indicativo e ao adjunto adverbial "todos os dias".

1.105. Vicente, você deixou de assinar o ponto ontem. (perfectivo) Aspecto devido do pretérito perfeito do indicativo.

1.106. Embora Élio deixe de partir quando um filho adoece, nunca atrasou com o trabalho. (imperfectivo, não acabado, habitual) Aspecto devido ao presente do subjuntivo e à oração adverbial temporal.

1.107. É possível que ele deixe de cantar esta música se eu pedir. (não aspecto, porque o presente do subjuntivo tem valor futuro).

Não encontramos exemplos onde, com o verbo nos presentes ou nos pretéritos imperfeitos do indicativo e do subjuntivo, tivéssemos aspecto cursivo.

Quando a perífrase "deixar + de + infinitivo" aparece combinada à perífrase "estar + gerúndio", temos aspecto terminativo com todas as flexões verbais em que a perífrase de estar marca imperfectivo (exemplos 1.108 a 1.111). Se o verbo principal for de evento, a frase fica ambígua e podemos ter uma interpretação iterativa (exemplo 1112), o que nem sempre ocorre (exemplo 1.113). 
1.108. Celso está deixando de fumar. (imperfectivo, terminativo, não acabado).

1.109. Quando fui visitá-lo, Márcio estava deixando de beber. (imperfectivo, terminativo, não acabado).

1.110. Quando você for competir eu já estarei deixando de jogar. (imperfectivo, terminativo, não acabado).

1.111. Embora eu esteja deixando de amar você, creio que nunca o odiarei. (imperfectivo, terminativo, não acabado).

1.112. Rafael está deixando de fechar a porta. (imperfectivo, não acabado, iterativo em uma interpretação ou imperfectivo, terminativo, não acabado, em outra interpretação).

1.113. Aroldo está deixando de chegar atrasado. (imperfectivo, terminativo, não acabado).

Não encontramos exemplos onde, com o verbo nos presentes ou nos pretéritos imperfeitos do indicativo e do subjuntivo (que são as flexões temporais que podem expressar imperfectivo), tivéssemos aspecto terminativo. Parece que os únicos casos em que podemos dizer que este aspecto aparece é com o verbo nos pretéritos imperfeitos em frases como (1.114) e (1.115) abaixo.

1.114. Quando a vi no mês passado, Ana deixava de dançar (= estava deixando de dançar). (imperfectivo, não acabado, terminativo).

1.115. Embora Sérgio deixasse de fumar (= estivesse deixando de fumar) quando o conheci, ele não estava certo se isto era o melhor. (imperfectivo, não acabado, terminativo).

Naturalmente os falantes empregam de preferência a forma entre parênteses.

Para as formas de valor futuro e para os pretéritos perfeito e mais-que-perfeito do indicativo da perífrase "deixar + de + infinitivo", valem os comentários feitos no item 8.12.2 para as mesmas formas da perífrase "acabar + de + infinitivo".

Na perífrase "deixar + de + infinitivo", só podemos falar em aspecto começado para a situação narrada, expressa pelo verbo no infinitivo, quando a perífrase tiver o significado de que uma situação em realização está sendo ou será interrompida. Nos pretéritos perfeito e mais-que-perfeito do indicativo, com esse significado, a situação narrada será acabada, com valor cessativo. ${ }^{8}$

\footnotetext{
${ }^{8}$ É bom que fique claro que o acabado da situação narrada, com os pretéritos perfeito e mais-que-perfeito do indicativo das perífrases "deixar ou parar ou cessar + de + infinitivo", significa apenas que a
} 


\subsection{1 - As PERÍFRASES DE CESSAR E PARAR}

As perífrases CESSAR + DE + INFINITIVO e PARAR + DE + INFINITIVO não marcam qualquer aspecto para a situação referencial, indicada pelo todo da perífrase, cujo aspecto será devido principalmente à flexão verbal e a outros fatores. A situação narrada, com os pretéritos perfeito e mais-que-perfeito, é acabada, com valor cessativo.135 As frases com a perífrase de "cessar" são sempre algo estranhas, ao que parece, porque normalmente não se diz que alguém cessa algo, mas sim que algo cessa. Isto leva o falante a preferir a perífrase de "parar". Vejamos alguns exemplos.

1.116. Só cessamos de embalar peças quando toca a sirene das dezoito horas. (imperfectivo, não acabado, habitual). - Aspecto devido ao presente do indicativo e à oração adverbial temporal.

1.117. Eles sempre param de trabalhar às dezoito horas. (imperfectivo, não acabado, habitual). - Aspecto devido à flexão temporal e ao adjunto adverbial "sempre".

1.118. Aos domingos, cessávamos de jogar ao anoitecer. (imperfectivo, não acabado, habitual). - Aspecto devido ao pretérito imperfeito do indicativo e ao adjunto adverbial "Aos domingos".

1.119. Parei de comprar neste armazém porque seus preços são mais altos.

a) S.R.: parar de comprar - perfectivo, acabado.

b) S.N.: comprar - acabado.

1.120. É preciso que você pare de dar informações a eles.

a) S.R.: parar de dar informações - não aspecto.

b) S.N.: dar informações: começado ou não acabado.

Quando temos aspecto habitual como em (1.116) a (1.118) em cada realização da situação referencial, a situação narrada é começada.

Quando as duas perífrases, em estudo neste item, aparecem combinadas à perífrase "estar + gerúndio", temos aspecto terminativo com todas as flexões verbais em que a perífrase de estar marca imperfectivo. Veja exemplos (1.121) a (1.125).

situação não está mais em realização, já que não houve o atingimento de um ponto terminal. Portanto, logicamente, mas não gramaticalmente, o acabado que temos com as perífrases "deixar ou parar ou cessar + de + infinitivo" é diferente do acabado que temos, por exemplo, com as perífrases "acabar ou terminar + de + infinitivo", uma vez que nas primeiras temos um ponto de cessamento, de interrupção na realização da situação narrada e não um ponto de término da mesma, como nas últimas. 
1.121. Seu irmão está parando de estudar. (imperfectivo, terminativo, não acabado).

1.122. Os operários estavam cessando de capinar a plantação, quando chegou a ordem para continuarem até mais tarde. (imperfectivo, terminativo, não acabado).

1.123. Estará parando de ventar quando formos colocar os enfeites na rua. (imperfectivo, terminativo, não acabado).

1.124. Embora os homens estejam cessando de caçar os animais, muitas espécies estão seriamente ameaçadas. (imperfectivo, terminativo, não acabado).

1.125. Estarmos parando de comer não significa que a festa esteja no fim. (imperfectivo, terminativo, não acabado).

O aspecto terminativo também parece ser possível com as perífrases "cessar ou parar + de + infinitivo" nos pretéritos imperfeitos do indicativo e do subjuntivo em frases como (1.126) e (1.127) abaixo:

1.126. Quando cheguei ao hospital Jaime cessava de respirar. (= estava cessando de respirar) - (imperfectivo, terminativo, não acabado).

1.127. Embora parasse de chover (= estivesse parando de chover) quando saímos do cinema, ainda nos molhamos um pouco. (imperfectivo, terminativo, não acabado).

Para as formas de valor futuro e para os pretéritos perfeito e mais-que-perfeito do indicativo das perífrases "cessar ou parar + de + infinitivo", valem os comentários feitos para as mesmas formas da perífrase "acabar + de + infinitivo" no item 8.12.2.

\subsection{2 - As PERÍFRASES DE ACABAR}

\subsection{1 - ACABAR + GERÚNDIO/ACABAR + POR + INFINITIVO}

As perífrases ACABAR + GERÚNDIO e ACABAR + POR + INFINITIVO não marcam aspecto. Estas duas perífrases expressam um resultado final ou uma consequência. Em virtude desse significado, são frequentes as formas com valor futuro e nenhuma atualização aspectual. $\mathrm{O}$ aspecto atualizado em frases com estas duas perífrases não depende delas, mas de outros fatores, principalmente a flexão verbal e a influência de elementos adverbiais. Vejamos alguns exemplos. 
1.128. Não o amolem muito, ou ele acaba partindo e nos deixando sozinhos aqui. (não aspecto devido ao valor de futuro da forma).

1.129. Você desobedece e sempre acaba por quebrar alguma coisa. (imperfectivo, não acabado, habitual). - Aspecto devido ao presente do indicativo e ao adjunto adverbial "sempre".

1.130. Telma ficava se aprontando tanto que acabava chegando atrasada ao serviço. (imperfectivo, não acabado, habitual). - Aspecto devido ao pretérito imperfeito do indicativo.

1.131. Celina procurou tanto e acabou por comprar um vestido dos mais simples. (perfectivo). - Aspecto devido ao pretérito perfeito do indicativo.

1.132. É possível que acabe concordando com a ideia de vocês. (não aspecto devido ao valor de futuro da forma).

\subsection{2 - ACABAR + DE + INFINITIVO}

A perífrase ACABAR + DE + INFINITIVO apresenta uma série de particularidades que passamos a expor.

Esta perífrase marca o aspecto acabado nos presentes e pretéritos imperfeitos do indicativo e do subjuntivo e nos pretéritos perfeito e mais-que-perfeito do indicativo. Ao lado do aspecto acabado, há também a expressão da noção temporal de passado recente. Vejamos os exemplos (1.133) a (1.138) abaixo.

1.133. O presidente acaba de receber o telegrama. (acabado).

1.134. Gil acabava de pintar sua obra prima. (acabado).

1.135. Acabei de redigir a mensagem que o senhor pediu.

a) S.R.: acabar de redigir - perfectivo, acabado, pontual.

b) S.N.: redigir - acabado.

1.136. Quando the telefonei, ele acabara de ler seu livro. (acabado).

1.137. Embora Rui acabe de assar um bolo, não o comeremos hoje. (acabado).

1.138. Embora Sérgio acabasse de decidir o que faria, não nos revelou nada. (acabado).

Quando o verbo principal é um evento não há qualquer dúvida sobre a presença do aspecto acabado, mas se temos um processo (cf. exemplos 1.134 e 1.137) a frase parece ambígua e, além da interpretação como acabado, podemos ter também uma interpretação em que teríamos os aspectos imperfectivo, não acabado e terminativo. 
Esta última interpretação só é possível nos presentes e pretéritos imperfeitos do indicativo e do subjuntivo, e se torna mais evidente quando algum elemento na frase, ou no contexto, torna esta interpretação mais plausível (cf. exemplos 1.139 a 1.141).

1.139. a - Acabo de escrever uma carta para papai. (acabado). b - -Vânia, o que você está fazendo?

- Acabo de escrever uma carta para papai. (imperfectivo, terminativo, não acabado).

1.140. Quando cheguei em casa, Sérgio acabava de encerar o chão. (imperfectivo, terminativo, não acabado).

1.141. Embora ele acabasse de impermeabilizar o vaso quando cheguei, não sei onde ele conseguiu o material para fazê-lo. (imperfectivo, terminativo, não acabado).

Em (1.139b), o contexto linguístico praticamente exige que se interprete a frase, como expressando uma situação não acabada. Em (1.140) e (1.141), as orações temporais, iniciadas por "quando", exercem o papel de presentificadores para as situações expressas pelos pretéritos imperfeitos, o que favorece a interpretação com os aspectos especificados, embora a frase continue ambígua.

Para que a perífrase "acabar + de + infinitivo" marque o terminativo sem qualquer dubiedade, o falante prefere combiná-la com a perífrase "estar + gerúndio". Neste caso, temos o aspecto terminativo claramente expresso, com todas as flexões verbais, exceto os pretéritos perfeito e mais-que-perfeito do indicativo. Exemplos.

1.142. Manuel está acabando de picar a carne para fazer o estrogonofe. (imperfectivo, terminativo, não acabado).

1.143. Quando voltarmos, Dona Eufrásia estará acabando de fazer o almoço. (imperfectivo, terminativo, não acabado).

1.144. É possível que Ronaldo esteja acabando de encadernar o livro. (imperfectivo, terminativo, não acabado).

1.145. Estar acabando de arrumar a biblioteca deixou-o muito satisfeito. (imperfectivo, terminativo, não acabado).

No futuro do presente, do pretérito e do subjuntivo, nas formas de sentido futuro do presente e pretérito imperfeito do indicativo e do subjuntivo e nos pretéritos perfeito e mais-que-perfeito do indicativo, teremos aspecto terminativo para a situação narrada, expressa pelo infinitivo, se na frase houver um elemento adverbial 
que precise o momento de término da situação. Além disso, nos pretéritos perfeito e mais-que-perfeito, temos também o acabado para a situação narrada. Poder-se-ia supor que nas formas de futuro tivéssemos o aspecto começado ou não acabado para a situação narrada. Isto, entretanto, não é verdade, pois o exame dos exemplos nos mostra que não há nada na frase que nos permite afirmar se a situação está ou não começada (cf. item 4.2.9). A determinação disso depende apenas do conhecimento da realidade, o que evidencia que o aspecto em questão não está gramaticalmente marcado (exemplos 1.146 a 1.150). Se não houver o elemento adverbial referido, não teremos aspecto terminativo para a situação narrada, pois aí a informação será apenas de que a situação acabou ou acabará sem apresentá-la em seu momento de término (exemplos 1.151 e 1.152). Nas formas de futuro, não há aspecto para a situação referencial expressa por "acabar + de + infinitivo" (exemplos 1.146, 1.147 e 1.149 a 1.151), enquanto que, nos pretéritos perfeito e mais-que-perfeito, temos o perfectivo, o acabado e o pontual (exemplos 1.148 e 1.152).

1.146. Esta firma acabará de construir o estádio em junho. (S.N.: terminativo).

1.147. Se não tivesse de ir ao supermercado, eu acabaria de ler este livro ao meio-dia. (S.N.: terminativo).

1.148. Acabei de arrumar a gaveta no exato instante em que o telefone tocou.

a) S.R.: acabar de arrumar - perfectivo, acabado, pontual.

b) S.N.: arrumar - acabado, terminativo.

1.149. Eu aviso você, se acabar de emoldurar seu quadro às três horas. (S.N.: terminativo).

1.150. É possível que eu acabe de conferir estes cálculos às dez horas, assim sendo, é melhor você vir depois do almoço. (S.N.: terminativo).

1.151. Se Deus quiser acabarei de pagar este terreno. (S.N. e S.R.: não aspecto).

1.152. O seu filho acabou de telefonar perguntando por você.

a - S.R.: acabar de telefonar - perfectivo, acabado, pontual.

b - S.N.: telefonar - acabado.

Nos presentes e pretéritos imperfeitos do indicativo e do subjuntivo, podemos ter o habitual para a situação referencial de "acabar + de + infinitivo", por influência de elementos adverbiais. Veja exemplos (1.153) e (1.154). 
1.153. Jorge sempre acaba de atender os fregueses entre dezenove e vinte horas. (imperfectivo, não acabado, habitual).

1.154. Embora todos os dias Sérgio acabasse de conferir as notas bem tarde, naquele dia havia pouco trabalho e ele foi para casa mais cedo. (imperfectivo, não acabado, habitual).

\subsection{3 - As PERÍFRASES DE TERMINAR}

\subsection{1 - TERMINAR + GERÚNDIO}

A perífrase TERMINAR + GERÚNDIO não marca aspecto. Ela indica que alguém terminou, termina ou terminará algo de um determinado modo, indicado pelo verbo no gerúndio. Assim sendo, o aspecto expresso em frases com esta perífrase não depende dela, mas de outros fatores. A situação expressa pelo gerúndio não apresenta qualquer aspecto. Exemplos:

1.155. Frei Genaro sempre termina o sermão propondo um tema para reflexão. (imperfectivo, não acabado, habitual) - Aspecto devido ao presente do indicativo e ao adjunto adverbial "sempre".

1.156. Ele me fez uma porção de desaforos e terminou falando que você não presta. (perfectivo) - Aspecto devido ao pretérito perfeito do indicativo.

Essa perífrase pode também ser usada com valor semelhante ao que especificamos para "acabar + gerúndio" em 8.12.1, mas é pouco usada neste sentido, pois o falante prefere a perífrase de "acabar".

\subsection{2 - TERMINAR + DE + INFINITIVO}

A perífrase TERMINAR + DE + INFINITIVO tem várias particularidades que expomos abaixo. Como se poderá observar, ela apresenta muitas semelhanças com "acabar + de + infinitivo" no que se refere à expressão do aspecto.

No presente e pretérito imperfeito do indicativo e do subjuntivo a perífrase "terminar + de + infinitivo" marca o aspecto terminativo (cf. exemplos 1.157 a 1.160). Nas frases de presente, teremos este aspecto se a frase for usada numa descrição simultânea e, nas de pretérito imperfeito, nós o teremos se na frase houver uma outra situação passada (normalmente expressa por oração adverbial de tempo com o verbo no pretérito perfeito do indicativo) em relação 
à qual a situação expressa pelo pretérito imperfeito é presente, ou um adjunto adverbial que indica um momento do passado, em relação ao qual o término da situação é presente.

1.157. Rogério termina de ler o livro que você lhe emprestou. (imperfectivo, terminativo, não acabado).

1.158. Quando cheguei ao apartamento, Celso terminava de montar as estantes. (imperfectivo, terminativo, não acabado).

1.159. Embora neste instante o governador termine de explicar o porquê da não concessão do aumento, não se pode sentir qual será a reação dos representantes de classe aqui presentes. (imperfectivo, terminativo, não acabado).

1.160. Embora Raul terminasse de compor a música quando estive lá, ele não quis que eu a visse. (imperfectivo, terminativo, não acabado).

Embora se possa expressar o terminativo por esta forma, os falantes preferem fazê-lo combinando a perífrase "terminar + de + infinitivo" com a perífrase "estar + gerúndio". Neste caso, o aspecto fica claramente expresso com todas as flexões verbais, exceto os pretéritos perfeito e mais-que-perfeito do indicativo. Exemplos:

1.161. Rogério está terminando de ler o livro que você lhe emprestou. (imperfectivo, terminativo, não acabado).

1.162. Quando cheguei ao apartamento, Celso estava terminando de montar as estantes. (imperfectivo, terminativo, não acabado).

1.163. Embora neste instante o governador esteja terminando de explicar o porquê da não concessão do aumento, não se pode sentir qual será a reação dos representantes de classe aqui presentes. (imperfectivo, terminativo, não acabado).

1.164. Embora Raul estivesse terminando de compor a música quando estive lá, ele não quis que eu a visse. (imperfectivo, terminativo, não acabado).

1.165. Quando chegarmos ao depósito da loja, os rapazes estarão acabando de embalar as mercadorias. (imperfectivo, terminativo, não acabado).

1.166. É muito bom vocês já estarem terminando de colher as laranjas. (imperfectivo, terminativo, não acabado). 
Se o verbo é de evento e tem sujeito singular (se for intransitivo) ou objeto singular (se for transitivo), a frase será estranha ou exigirá interpretação especial para ser aceita. Veja exemplos (1.167) e (1.168).

1.167. a - * O trem termina de partir. (esta frase só será aceita se interpretada como "O trem acaba de partir", mas os falantes não a utilizam com este sentido, que é mais naturalmente expresso pela perífrase de "acabar").

b - Os exilados terminam de partir. (imperfectivo, terminativo, não acabado).

1.168. a - * Alberto termina de engolir o comprimido. (idem a 1.167a). b - Alberto termina de engolir os docinhos que ganhou. (imperfectivo, terminativo, não acabado).

Frases como (1.167b) e (1.168b) têm sempre, respectivamente, o sentido de que alguns dos seres indicados pelo sujeito já realizaram a ação indicada pelo infinitivo e os últimos estão para realizá-la ou a estão realizando, e que alguém já fez a ação indicada pelo infinitivo com alguns seres ou coisas, indicadas pelo objeto e ainda vai fazê-la, ou está fazendo, com os últimos.

Nos presentes e pretéritos imperfeitos do indicativo e subjuntivo temos, por influência de elementos adverbiais, o habitual para a situação referencial indicada por "terminar + de + infinitivo". Exemplos:

1.169. Quando quer ir ao cinema, Ofrânio termina de atender os clientes mais cedo. (imperfectivo, não acabado, habitual).

1.170. Embora você sempre terminasse de catar o arroz primeiro do que eu, não o fazia bem. (imperfectivo, não acabado, habitual).

No futuro do presente, do pretérito e do subjuntivo, nas formas de sentido futuro do presente e pretérito imperfeito do indicativo e subjuntivo e nos pretéritos perfeito e mais-que-perfeito do indicativo; temos exatamente o mesmo quadro aspectual que especificamos em 8.12.2 para a perífrase "acabar + de + infinitivo" nestes tempos (cf. comentários aos exemplos 1.146 a 1.152). A seguir, damos alguns exemplos com a perífrase "terminar + de + infinitivo".

1.171. Terminarei de envernizar seus móveis às dezesseis horas $\mathrm{O}$ mais tardar. (S.N.: terminativo). 
1.172. Se você me ajudasse, eu terminaria de capinar o quintal às quatorze horas e iria ao cinema com vocês. (S.N.: terminativo).

1.173. Você termina de medir as terras quinta-feira? (S.N.: terminativo).

1.174. Terminei de engraxar os sapatos exatamente no momento em que você tocou a campanhia.

a - S.R.: terminar de engraxar - perfectivo, acabado, pontual.

b - S.N.: engraxar - acabado, terminativo.

1.175. Se eu terminar de copiar estes dados às dezoito horas, como pretendo, irei à festa. (S.N.: terminativo).

1.176. É preciso que terminemos de fazer o almoço ao meio-dia. (S.N.: terminativo).

1.177. Será que você terminava de guardar as roupas para mim? (S.N. e S.R.: não aspecto).

1.178. É claro que Jorge terminará de sintecar a casa. (S.N. e S.R.: não aspecto).

1.179. Joaquim terminou de empilhar os tijolos; posso pagá-lo?

a - S.R.: terminar de empilhar - perfectivo, acabado, pontual.

b - S.N.: empilhar - acabado.

\subsection{4 - As PERÍFRASES INCEPTIVAS}

\subsection{1 - As PERÍFRASES DE COMEÇAR E PRINCIPIAR}

Inicialmente é preciso anotar que as perífrases de principiar são pouco usadas e talvez restritas a um registro mais culto, literário mesmo.

As perífrases COMEÇAR + GERÚNDIO e PRINCIPIAR + GERÚNDIO não marcam aspecto, mas indicam que alguém começou, começa ou começará algo de um determinado modo indicado pelo verbo no gerúndio, que indica também a primeira situação de uma série. $O$ aspecto presente em frases com estas perífrases não depende delas, mas de outros fatores, principalmente a flexão verbal de "começar" ou "principiar”. A situação expressa pelo gerúndio não apresenta qualquer aspecto. Exemplos:

1.180. Antônio começa caminhando e depois corre cada vez mais rápido. (imperfectivo, não acabado, habitual).

1.181. Bento começou limpando os vidros e depois passou para os lustres, teto, piso, etc. (perfectivo).

1.182. - Como você vai começar o "show"?

- Talvez eu comece tocando a canção que você fez. (não aspecto). 
1.183. João principiava a cena rodopiando no palco, como se dançasse. (imperfectivo, não acabado, habitual).

As perífrases COMEÇAR + A + INFINITIVO e PRINCIPIAR + A + INFINITIVO apresentam uma série de particularidades que expomos a seguir. Considerando o fato de que a primeira perífrase é mais usada, vamos apresentar a exemplificação sempre com ela, mesmo porque, para termos exemplos com a perífrase de "principiar", é suficiente substituir o verbo "começar" por "principiar" no mesmo tempo.

No presente e pretérito imperfeito do indicativo e subjuntivo, temos o aspecto inceptivo. Isto se as frases com os presentes são usadas em descrição simultânea; e, nas frases com os pretéritos imperfeitos, há a expressão de outra situação passada, normalmente por oração adverbial de tempo com o verbo no pretérito perfeito do indicativo, em relação à qual a situação expressa pelo pretérito imperfeito é presente, ou um adjunto adverbial que indica um momento do passado em relação ao qual o começo da situação é presente. Estes elementos podem não estar na frase, mas no contexto. Exemplos:

1.184. Começam a nascer as primeiras mudas de amor-perfeito. (imperfectivo, inceptivo, não acabado).

1.185. Naquele tempo Nice começava a subir na firma. (imperfectivo, inceptivo, não acabado).

1.186. Começava a chover quando saímos de casa. (imperfectivo, inceptivo, não acabado).

1.187. Embora comece a chover, vamos sair. (imperfectivo, inceptivo, não acabado).

1.188. Embora Gabriel apenas começasse a esculpir a estátua, já se podia notar que seria um belo trabalho. (imperfectivo, inceptivo, não acabado).

Embora o inceptivo possa ser marcado como especificamos acima, o falante prefere fazê-lo combinando as perífrases "começar ou principiar $+\mathrm{a}+$ infinitivo" com a perífrase "estar + gerúndio". Neste caso, temos aspecto inceptivo com todas as flexões verbais, exceto com os pretéritos perfeito e mais-que-perfeito do indicativo. Exemplos:

1.189. Sua roupa está começando a enxugar. (imperfectivo, não acabado, inceptivo).

1.190. Não se preocupe. Quando chegarmos à fazenda o pessoal ainda estará começando a dançar. (imperfectivo, inceptivo, não acabado). 
1.191. Se eu não tivesse ajudado Carlos, agora é que ele estaria começando a espalhar o milho ao sol. (imperfectivo, inceptivo, não acabado).

1.192. Embora esteja começando a escurecer, Gervásia ainda não voltou. (imperfectivo, inceptivo, não acabado).

1.193. Quando a calda estiver começando a dourar, você tira do fogo. (imperfectivo, inceptivo, não acabado).

1.194. Ondina estar começando a fumar deixou seu pai muito triste. (imperfectivo, inceptivo, não acabado).

1.195. Quando fui ver, o pernil estava começando a queimar. (imperfectivo, inceptivo, não acabado).

Nos presentes e pretéritos imperfeitos, podemos ter o habitual para a situação referencial indicada por "começar ou principiar + a + infinitivo" com ou sem a influência de elementos adverbiais. Exemplos:

1.196. A Dra. Lúcia começa a atender às 8 horas. (imperfectivo, não acabado, habitual).

1.197. Era só ventar um pouco mais frio, Gustavo começava a espirrar. (imperfectivo, não acabado, habitual).

1.198. Embora Jorge começasse a gritar quando me via, dizia à mãe que não tinha medo de mim. (imperfectivo, não acabado, habitual).

No futuro do presente, do pretérito e do subjuntivo, nas formas de sentido futuro do presente e pretérito imperfeito do indicativo (raramente) e do subjuntivo (mais frequentemente) e nos pretéritos perfeito e mais-que-perfeito do indicativo; teremos aspecto inceptivo para a situação narrada, expressa pelo infinitivo, se na frase houver um elemento adverbial que precise o momento de início da situação. Além disso, nos pretéritos perfeito e mais-que-perfeito, temos também o começado para a situação narrada. Poder-se-ia supor que, nas formas de futuro, tivéssemos aspecto não começado para a situação narrada, mas aqui o não começo da situação é apenas deduzido logicamente e não marcado gramaticalmente, portanto não podemos dizer que este aspecto esteja aí expresso (exemplos 1.199 a 1.204). Se não houver o elemento adverbial referido, não teremos aspecto inceptivo para a situação narrada, pois a informação será apenas de que a situação começou ou começará, sem apresentá-la em seu momento de início (exemplos 1.205 a 1.207). Nas formas de futuro, não há aspecto para a situação referencial expressa por "começar ou 
principiar + a + infinitivo" (exemplos 1.199, 1.200, 1.202 a 1.206), enquanto que nos pretéritos perfeito e mais-que-perfeito temos o perfectivo, o acabado e o pontual (exemplos 1.201 e 1.207).

1.199. Sérgio começará a preparar o churrasco quando você chegar. (S.N.: inceptivo).

1.200. Se você permitisse eu começaria a vacinar o gado logo às cinco horas. (S.N.: inceptivo).

1.201. Comecei a pintar estas cadeiras às nove da manhã e não acabei até agora.

a - S.R.: começar a pintar - perfectivo, acabado, pontual.

b - S.N.: pintar - inceptivo, começado.

1.202. Se eu começar a copiar isto agora, te entrego o caderno à tarde. (S.N.: inceptivo).

1.203. É preciso que ele comece a cantar no momento em que a luz incidir sobre ele. (S.N.: inceptivo).

1.204. Se os convidados começassem a chegar às vinte e duas horas, não haveria problema. (S.N.: inceptivo).

1.205. Quando você começa a elaborar seu projeto? (S.N. e S.R.: não aspecto).

1.206. Tenho certeza que Romão começará a imaginar coisas, quando ficar sabendo disso. (S.N. e S.R.: não aspecto).

1.207. Sílvio começara a justificar sua falta, quando percebeu que o chefe não aceitaria nenhuma explicação.

a - S.R.: começar a justificar - perfectivo, acabado, pontual.

b - S.N.: justificar - começado.

\subsection{2 - A PERÍFRASE DE PASSAR}

A perífrase PASSAR $+\mathrm{A}+$ INFINITIVO tem, basicamente, as mesmas possibilidades de expressão aspectual que a perífrase "começar + a + infinitivo", diferindo desta principalmente por trazer a implicação de que havia uma situação em realização e houve, está havendo ou haverá uma mudança de situação.

O presente e pretérito imperfeito do indicativo e do subjuntivo têm a possibilidade de expressar o inceptivo, como se pode observar no exemplo (1.208).

1.208. Itamar passava a respirar melhor quando cheguei ao hospital. (imperfectivo, inceptivo, não acabado). 
Embora uma frase como (1.208) seja possível, o falante prefere usar "começar" no lugar de "passar". Na verdade, no presente e pretérito imperfeito do indicativo e do subjuntivo, normalmente temos, com esta perífrase, frases de valor habitual (exemplos 1209 a 1211), ou com valor futuro e sem atualização de aspectos (exemplos 1.212 e 1.213).

1.209. Quando chega o inverno, as pessoas passam a beber mais vinho. (imperfectivo, não acabado, habitual).

1.210. Quando João percebia que eu estava cansada, passava a dançar mais lentamente. (imperfectivo, não acabado, habitual).

1.211. Embora Sérgio sempre passe a trabalhar para a equipe vencedora, não é um mau sujeito. (imperfectivo, inceptivo, habitual).

1.212. De amanhã em diante, passo a caminhar durante uma hora em vez de meia.

1.213. Se Marta passasse a cantar num tom mais baixo, agradaria mais.

Nos pretéritos perfeito e mais-que-perfeito do indicativo, temos os aspectos perfectivo e acabado para a situação referencial de "passar + a + infinitivo" e o aspecto começado para a situação narrada indicada pelo infinitivo (exemplos $1.214 \mathrm{e} 1.215$ ). Se na frase houver um elemento adverbial, que indique o momento em que se passou da realização de uma situação para outra, temos também o aspecto inceptivo para a situação narrada (exemplo 1.216), mas isto é pouco comum.

1.214. Desde aquele evento o diretor passou a me respeitar mais.

a - S.R.: passar a respeitar - perfectivo, acabado.

b - S.N.: respeitar - começado.

1.215. Depois do assalto, vovô passara a guardar o dinheiro no banco. a - S.R.: passar a guardar - perfectivo, acabado.

b - S.N.: guardar - começado.

1.216. Às dez horas ele passou a delirar, doutor!

a - S.R.: passar a delirar - perfectivo, acabado.

b - S.N.: delirar - inceptivo, começado.

Nas frases em que a perífrase está numa forma de valor futuro, normalmente não há atualização de aspecto (exemplos 1.217 e 1.218). Se na frase houver um elemento adverbial que indique o momento em que se dará a mudança de situação 
(o que é pouco comum), teremos aspecto inceptivo para a situação narrada expressa pelo infinitivo (exemplo 1.219).

1.217. Tenho certeza de que, depois de ler esse livro, você passará a entender melhor a vida.

1.218. Se você passar a chegar mais cedo em casa, deixará sua mãe mais tranquila.

1.219. Ao meio-dia, o presidente baixará essa alavanca e, nesse exato momento, o rio passará a correr pelo desvio do leito que fizemos.

Também quando combinada à perífrase "estar + gerúndio", a perífrase "passar + a + infinitivo" expressa aspecto inceptivo. Exemplos:

1.220. Mardem não estará passando a vender mais barato para nos prejudicar? (S.N.: inceptivo).

1.221. O professor está passando a expor com mais clareza. (S.N.: inceptivo).

1.222. Embora ele esteja passando a me respeitar mais, não acredito que ele mude muito. (S.N.: inceptivo).

\subsection{3 - OUTRAS PERÍFRASES INCEPTIVAS}

Neste item, falaremos de um grupo de perífrases que são colocadas no grupo das inceptivas, porque referem que algo começou a ser feito, mas que aspectualmente não são propriamente inceptivas, pelo menos no uso que delas fazem os falantes. Estas perífrases ${ }^{9}$ estão listadas em (1.223) abaixo:

\footnotetext{
${ }^{9}$ Várias destas perífrases são apresentadas por Castilho (1967, p.64-67, 110), como marcando o aspecto "Imperfectivo Inceptivo Propriamente Dito". A quase totalidade dos exemplos por ele apresentados tem o verbo no pretérito perfeito do indicativo, em que ele diz haver este aspecto. Como se verá, nossa análise difere da de Castilho.
} 


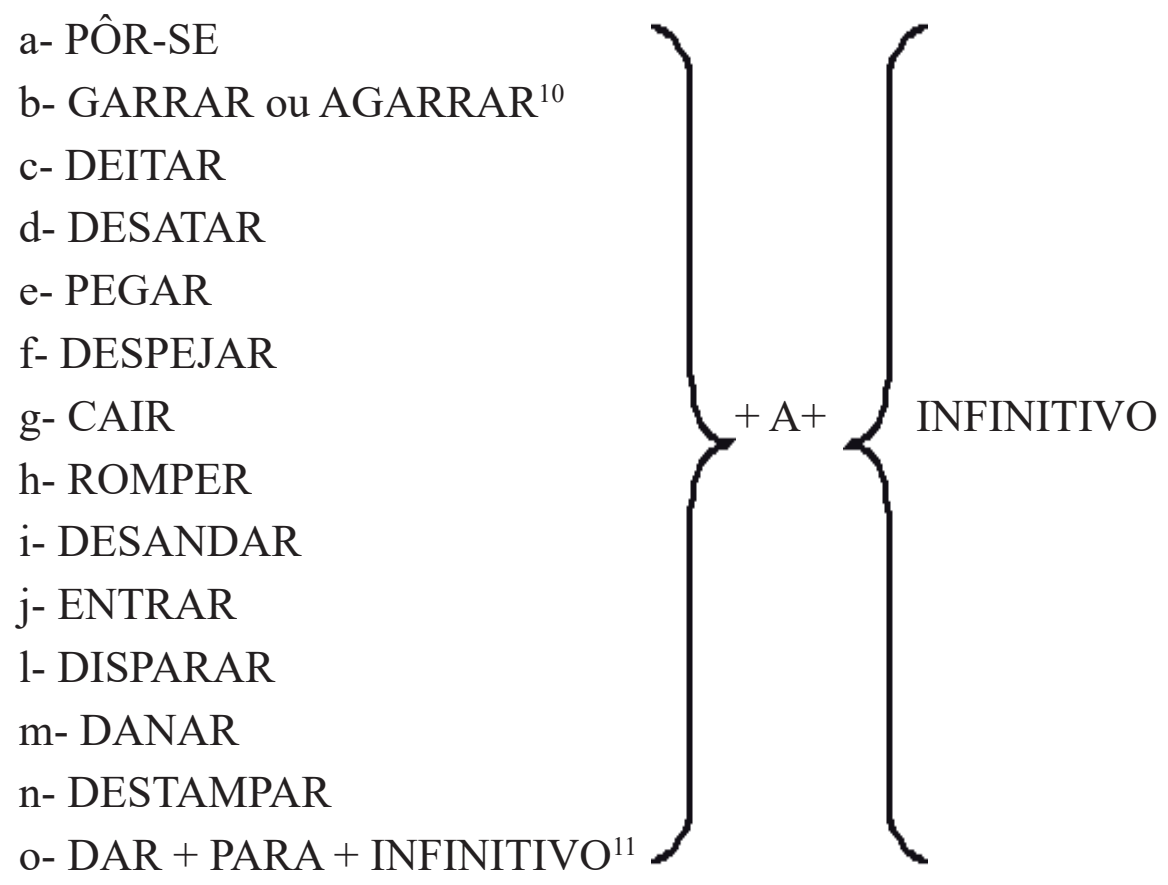

Teoricamente estas perífrases deveriam marcar o aspecto inceptivo nos mesmos casos em que a perífrase "começar + a + infinitivo", mas os falantes não as usam marcando este aspecto. Mesmo se ocorrer (no presente e pretérito imperfeito do indicativo e do subjuntivo), será pouco frequente e natural, como se pode observar nas frases (1.224) e (1.225).

1.224. Quando eu cheguei de manhã os rapazes já se punham a caminhar. (imperfectivo, inceptivo, não acabado).

1.225. Agora os concorrentes entram a procurar os objetos pedidos. (imperfectivo, inceptivo, não acabado).

A frase (1.225) tem de estar colocada num contexto de descrição simultânea para ter este valor, caso contrário, tende a ser interpretada com sentido futuro e aspecto não atualizado.

Nem mesmo em combinação com a perífrase "estar + gerúndio", estas perífrases marcam aspecto inceptivo de maneira frequente ou pelo menos natural. Veja exemplos (1.226) e (1.227).

\footnotetext{
${ }^{10}$ Muitas dessas perífrases são de uso popular apenas. Aulete (1974), Fernandes (1965) e Ferreira (1975) registram os verbos "garrar" e "agarrar", mas não registram este seu uso. (AULETE, F. J. C. Dicionário contemporâneo da língua portuguesa. 3. ed. rev. atual. e aum. Rio de Janeiro: Delta, 1974.).

${ }^{11}$ Aqui poderíamos acrescentar ainda duas perífrases com o auxiliar "dar". Não as colocamos porque têm um uso literário bastante restrito. São elas: DAR-SE + A + INFINITIVO e DAR + EM + INFINITIVO. A perífrase "dar + para + infinitivo" pode também ter o significado de que alguém tem aptidão para fazer algo. Neste caso não temos propriamente uma perífrase mas um sentido particular do verbo dar.
} 
1.226. (?) Cecília está garrando a gritar de medo. (imperfectivo, inceptivo, não acabado).

1.227. (?) Quando você menos esperar, estarei disparando a ganhar dinheiro. (imperfectivo, inceptivo, não acabado).

Diante de frases como (1.224) a (1.227), falantes consultados as aceitam, mas sempre com a ressalva de que são um pouco estranhas, ou de que nunca ouviram ninguém se expressar desta forma.

No presente e pretérito imperfeito do indicativo e do subjuntivo, o que temos, normalmente, é o habitual para a situação referencial expressa pelo todo da perífrase, quase sempre com o auxílio de elementos adverbiais (adjuntos ou orações). Veja exemplos (1.228) a (1.234) abaixo. O aspecto aqui se deve à flexão temporal e outros fatores.

1.228. Joãozinho ficou com tanto medo de injeção que se põe a gritar quando me vê. (imperfectivo, não acabado, habitual).

1.229. Melissa garrava a fazer caretas, quando alguém ralhava com ela. (imperfectivo, não acabado, habitual).

1.230. Embora Dona Zica deite a falar da vida de todos quando está com raiva, não é má pessoa. (imperfectivo, não acabado, habitual).

1.231. Embora Júlia destampasse a engordar quando começava a comer muito doce, não conseguia se controlar. (imperfectivo, não acabado, habitual).

1.232. De vez em quando, meu irmão dá para esperar-me na porta do colégio. (imperfectivo, não acabado, habitual).

1.233. Quando ficava nervosa, Diná desatava a quebrar coisas. (imperfectivo, não acabado, habitual).

1.234. Embora Carlota rompa a maldizer quando se enfurece, na verdade não deseja o mal a ninguém. (imperfectivo, não acabado, habitual).

Às vezes o habitual é limítrofe com o indeterminado (exemplo 1.235), e é difícil a decisão entre um e outro.

1.235. A pessoa que está com falta de vitaminas dá para adoecer com frequência.

A maioria destas perífrases aparece mais frequentemente no pretérito perfeito do indicativo Algumas, em verdade, quase que só são usadas neste tempo e é interessante observar que todas elas formam frases mais naturais quando nele 
empregadas. No pretérito perfeito e também no pretérito mais-que-perfeito do indicativo, temos os aspectos perfectivo, acabado e pontual para a situação referencial, indicada pelo todo da perífrase, e o aspecto começado para a situação narrada, indicada pelo infinitivo. Exemplos:

1.236. Mais tarde, Márcia entendeu a piada e pegou a rir.

a - S.R.: pegar a rir - perfectivo, acabado, pontual.

b - S.N.: rir - começado.

1.237. Diante da pergunta do professor Benedito, Paulo despejara a recitar o ponto que sabia de cor, mas do qual não entendera nada. a - S.R.: despejar a recitar - perfectivo, acabado, pontual.

b - S.N.: recitar - começado.

1.238. Elza, vencida pelo cansaço, caiu logo a dormir.

a - S.R.: cair a dormir - perfectivo, acabado, pontual.

b - S.N.: dormir - começado.

1.239. Mamãe chamou o médico, porque Suzaninha desandara a comer terra.

a - S.R.: desandar a comer - perfectivo, acabado, pontual.

b - S.N.: comer - começado.

Se na frase houver um elemento adverbial que precise o momento de início da situação, teremos também o aspecto inceptivo para a situação narrada. Exemplos (1.240) e (1.241).

1.240. Ao meio dia, destampou a cair pedras do céu.

a - S.R.: destampar a cair - perfectivo, acabado, pontual.

b - S.N.: cair - inceptivo, começado.

1.241. Ao me ver, o cachorro danara a latir, acordando todo mundo. a - S.R.: danar a latir - perfectivo, acabado, pontual.

b - S.N.: latir - inceptivo, começado.

No futuro do presente, do pretérito e do subjuntivo e nas formas de valor futuro dos demais tempos (principalmente do presente e pretérito imperfeito do indicativo e do subjuntivo) não há atualização de aspecto. Exemplos:

1.242. Não vou contar isso a Tereza, porque tenho certeza que ela porse-á a gritar como uma louca. 
1.243. Se eu não a tivesse ajudado, ela desandaria a dizer que sou um malvado.

1.244. Se Rogério destampar a mexer com todo mundo, eu não fico com vocês na praia.

1.245. É possível que Nicomedes dane a procurar um selo destes, só para satisfazer o filho.

Se na frase houver um elemento adverbial que precise o momento de início da situação teremos o aspecto inceptivo para a situação narrada indicada pelo infinitivo, com o verbo nas formas futuras acima indicadas. Exemplo:

1.246. Às vinte e duas horas os fogos de artifício romperão a explodir no céu. (S.N.: explodir - inceptivo).

Às vezes, temos gerúndio no lugar de infinitivo. Castilho (1967, p.65) apresenta alguns exemplos, dois dos quais transcrevemos abaixo.

1.247. "Contemplando essa gente do segundo andar, me ponho imaginando a classe a que pertence." - (M. de Andrade)

1.248. "Crianças danadas para incomodar são as de entre um ano e cinco, que se chateiam logo e pegam choramingando: Mamãe, quero ir para casa [...]" - (R. de Queirós)

Todas estas perífrases atribuem à situação expressa pelo infinitivo um valor intensivo que termina por levar, frequentemente, a um valor iterativo ${ }^{12}$, principalmente se o verbo expressa um evento (exemplo 1.249), mas também com processos (exemplos 1.250 e 1.251). Castilho (1967, p.19 e 66-7) também aponta para esse valor iterativo, dizendo que, com DAR + PARA + INFINITIVO, ele sempre aparece (exemplo 1.250). Said Ali (1964, p.163) já observa que, "para significar que algum dos atos é duradouro ou se repete (negrito nosso) com frequência, empregamos em lugar do imperfeito usado na linguagem antiga, as formas perifrásticas pôr-se a fazer alguma coisa ou começar a fazer alguma coisa". Apesar desse valor iterativo para a situação narrada, não podemos falar em aspecto iterativo, pois a repetição da situação é logicamente deduzida, mas não gramaticalmente marcada.

1.249. Virgílio pôs-se a pular como um cabrito.

${ }^{12}$ Esse valor iterativo aparece também com as perífrases inceptivas citadas anteriormente. 
1.250. De uns tempos para cá ele deu para ler romances policiais.

1.251. Depois daquela notícia Hugo destampou a comprar terrenos.

\subsection{5 - As PERÍFRASES DE SER}

\subsection{1 - SER + PARTICÍPIO}

A perífrase SER + PARTICÍPIO de verbo transitivo, que aceita a voz passiva, não marca aspecto, mas sim a voz passiva. O aspecto vai ser o expresso pela flexão verbal e outros elementos. Exemplos (entre parênteses indicamos a que se deve o aspecto).

1.252. Os filhos são amados pelos pais. (imperfectivo, não acabado, indeterminado) (presente do indicativo).

1.253. Os quartos são limpos todos os dias. (imperfectivo, não acabado, habitual) (presente do indicativo e adjunto adverbial "todos os dias").

1.254. Quando os encontramos, a criança era conduzida pelo pai. (imperfectivo, cursivo, não acabado, durativo) (pretérito imperfeito do indicativo e oração adverbial temporal que funciona como presentificador).

1.255. Os troncos foram serrados com todo cuidado. (perfectivo, acabado).

1256. A música será cantada por um coro de crianças. (não aspecto) (futuro do presente).

1.257. Embora as roseiras sejam podadas em julho, só florescem em setembro. (imperfectivo, não acabado, habitual) (presente do subjuntivo e adjunto adverbial "em julho").

Embora haja possibilidade de expressão do cursivo no presente e pretérito imperfeito do indicativo e do subjuntivo, o falante sempre prefere a combinação com "estar + gerúndio" para deixar patente a presença deste aspecto. Exemplo:

1.258. Os galhos estão sendo cortados para facilitar o trabalho de transporte. (imperfectivo, cursivo, não acabado, durativo). 


\subsection{2 - SER + PARTICÍPIO VARIÁVEL}

A perífrase SER + PARTICÍPIO variável de verbo intransitivo marca o aspecto acabado para a situação narrada, que é a situação de cuja realização resulta o estado (situação referencial) expresso pela forma. Este terá aspecto imperfectivo, cursivo, não acabado e durativo.

Esta construção normalmente só aparece no presente e no pretérito imperfeito do indicativo, sendo pouco usada atualmente. Seguro Câmara Jr., hoje ela só aparece esporadicamente na língua literária.

Bechara (1977, p.111) apresenta esta construção como exprimindo que a ação verbal está concluída. Câmara Júnior (1974a, p.86) diz que ela marca aspecto permansivo.

Vejamos alguns exemplos:

1.259. Era chegada a ocasião da fuga.

1.260. São passados três meses.

1.261. "Meu Deus, meu Deus, pois a isto somos chegados."13

\subsection{3 - SER + DE + INFINITIVO}

A perífrase SER + DE + INFINITIVO marca o aspecto habitual para a situação narrada indicada pelo infinitivo e o aspecto indeterminado, para a situação referencial indicada pelo todo da perífrase, com todas as flexões verbais. Outros aspectos presentes na frase vão depender destas flexões ou de outros fatores. O verbo "ser" mantém seu status de verbo de estado, o que nos dá os fatos de expressão dos aspectos já comentados, quando falamos das flexões verbais, como, por exemplo, a expressão do acabado nos pretéritos perfeito e mais-que-perfeito do indicativo.

As frases construídas com esta perífrase têm sempre a função de caracterizar seres e coisas (cf. item 4.2.5), em que "de + infinitivo" tem valor adjetivo, indicando a característica do sujeito criada pelo hábito de realizar a situação expressa pelo infinitivo.

O que acabamos de dizer pode ser observado nos exemplos (1262) a (1270).

${ }^{13}$ Os exemplos (1259) e (1260) são de Bechara (1977, p.111). Exemplo (1261) apud Câmara Júnior (1974a, p.86). Said Ali (1971, p.160, § 816) apresenta vários exemplos com a construção em estudo. 
1.262. Eu não sou de levar desaforos para casa.

a - S.R. - imperfectivo, não acabado, indeterminado.

b - S.N. - habitual.

1.263. Abadio era de partir sem se despedir de ninguém.

a - S.R. - imperfectivo, não acabado, indeterminado.

b - S.N. - habitual.

1.264. Mário foi de amar uma hoje outra amanhã, até que encontrou o verdadeiro amor.

a - S.R. - perfectivo, acabado, indeterminado.

b - S.N. - habitual.

1.265. Ildefonso nunca fora de desrespeitar ninguém, por isso todos estranharam sua atitude.

a - S.R. - perfectivo, acabado, indeterminado.

b - S.N. - habitual.

1.266. Este menino, quando for moço, será de chegar tarde em casa.

a - S.R. - indeterminado.

b - S.N. - habitual.

1.267. Hilda seria de chegar atrasada aos lugares, se o marido não estivesse sempre a apressá-la.

a - S.R. - imperfectivo, não acabado, indeterminado.

b - S.N. - habitual.

1.268. Embora Josafá seja de ajudar todo mundo, não quis ajudar-me. a - S.R. - imperfectivo, não acabado, indeterminado.

b - S.N. - habitual.

1.269. Embora César fosse de observar tudo, não percebeu a modificação que fiz na sala.

a - S.R. - imperfectivo, não acabado, indeterminado.

b - S.N. - habitual.

1.270. Sendo de dizer a verdade, Guilherme não aceitava a ideia de ter que mentir daquela vez.

a - S.R. - imperfectivo, não acabado, indeterminado.

b - S.N. - habitual.

\subsection{6 - Diferenças ENTRE AS PERÍfRASES QUe EXPRESSAM O MESMO ASPECTO}

Como se pôde observar, é frequente termos mais de uma perífrase para expressão do mesmo aspecto. Pode-se notar, entretanto, que normalmente há uma diferença entre elas. Essa diferença se deve, quase sempre, à expressão de uma 
noção semântica qualquer ou de uma noção de tempo, ou é apenas uma diferença de uso em registros ou dialetos distintos.

Neste item, não fazemos uma análise minuciosa das diferenças existentes entre as perífrases que expressam o mesmo aspecto, apenas damos alguns exemplos a título de esclarecimento.

A diferença entre "estar + gerúndio" e "vir + gerúndio" é temporal: a primeira se refere apenas ao momento em que se fala ou de que se fala; a segunda indica que a situação se desenvolve até o momento em que se fala ou de que se fala, a partir de um momento anterior a eles. Considerando os casos em que "ir + gerúndio" também marca os aspectos imperfectivo, cursivo, não acabado e durativo, temos um sistema completo na língua que representamos no esquema de (1.271).

1.271 .

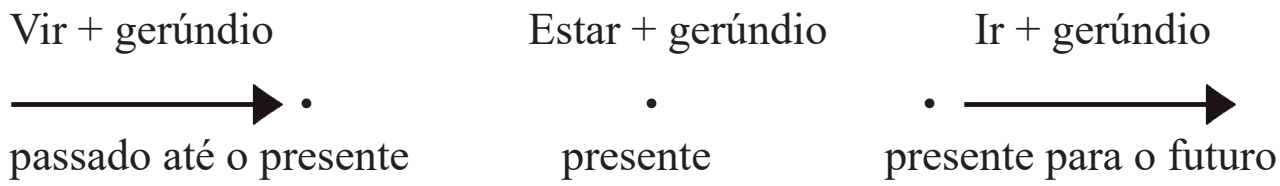

"Ter (no presente do indicativo) + particípio" e "Andar + gerúndio", ambas marcadoras de iterativo, também se distinguem pelo tempo, como demonstrado pelo esquema (1272).

1.272 .

Ter (presente do indicativo) + particípio

Andar + gerúndio

passado até o presente

presente

"Andar + gerúndio", quando marca cursivo e durativo em vez de iterativo, é diferente de "estar + gerúndio", porque se refere a um período de tempo maior que o referido pela segunda perífrase que só evoca um momento.

As perífrases "estar + por + infinitivo", "estar + gerúndio" e "estar + particípio" se distinguem, como já dissemos, por atribuir à situação expressa pelo verbo principal, respectivamente os aspectos não começado, começado ou não acabado e acabado. Constituem, assim, um sistema completo em relação às fases de realização.

Já especificamos, em 8.3.1, a diferença entre as perífrases de aspecto não começado com o auxiliar "estar". "Ficar + por + infinitivo" se distingue das três perífrases com "estar" por indicar que o estado de "por + infinitivo" permanece além de um limite previsto para o seu fim. 
As perífrases "ter + particípio" e "haver + particípio" apresentam uma diferença de registro já que a segunda, além de pouco usada, aparece quase que exclusivamente na linguagem culta e literária.

"Estar + para + infinitivo", "ir + infinitivo" e "ir (pretérito imperfeito do indicativo) + gerúndio", quando marcando iminência de ação, diferem, por expressar, nesta ordem, um grau crescente de iminência.

As perífrases que marcam o aspecto habitual diferem da seguinte maneira: "viver + gerúndio" e "viver + a + infinitivo" (a segunda sendo pouco usada) marcam o habitual, para processos e eventos, enquanto "viver + particípio" o marca para os estados. "Ser + de + infinitivo" marca o habitual sempre com a função de caracterizar seres e coisas. "Costumar + infinitivo" marca o habitual para processos e eventos, e difere das perífrases de viver pela frequência de realização da situação que é maior com a perífrase de viver. "Usar + infinitivo" tem o mesmo valor de "costumar + infinitivo", tendo aplicação mais restrita, pois normalmente, é usada apenas com sujeito caracterizado como humano.

Além das diferenças de significado já especificadas em 8.14, as perífrases inceptivas, normalmente, se distinguem por serem variantes regionais ou de registros. Assim, por exemplo, "entrar + a + infinitivo" é mais usada em Portugal que no Brasil. "Pôr-se + a + infinitivo" normalmente é usada em um padrão mais culto de linguagem, enquanto "disparar, danar e destampar ${ }^{14}+\mathrm{a}+$ infinitivo" têm uso mais popular e familiar. Há também diferenças de significado, pois "romper $+\mathrm{a}+$ infinitivo", por exemplo, expressa um início mais momentâneo e com uma certa concentração de energia do sujeito, que não existe nas demais perífrases. A determinação das diferenças de significado entre as perífrases de (1.223) exige uma análise sêmica que não cabe fazer aqui, mas fica como sugestão para estudos posteriores.

\subsection{7 - CONSIDERAÇÕES FINAIS}

É interessante observar que o único aspecto que não é marcado por perífrase é o pontual. Considerando que temos várias perífrases que marcam o aspecto durativo, confirma-se aqui o que afirmamos em 3.1: que a Língua Portuguesa tende a apresentar as situações, mais como durativas do que pontuais.

Há de se anotar também que nenhuma perífrase marcadora de aspecto imperfectivo, ou de tendência imperfectiva, leva os pretéritos perfeito e mais-que-perfeito do indicativo a deixar de marcar o aspecto perfectivo. Dessa forma, todas as perífrases, nestes dois tempos, têm aspecto perfectivo.

\footnotetext{
${ }^{14} \mathrm{O}$ dicionário Caldas Aulete registra esse uso do verbo destampar como familiar.
} 
É interessante observar que, normalmente, quando a situação narrada tem aspecto não acabado, a perífrase é com "gerúndio" ou "a + infinitivo" e, quando ela é acabada, a perífrase é de "particípio". Isto está ligado ao fato, já referido, de que o gerúndio apresentaria a situação como não acabada e o particípio, como acabada.

Uma outra possibilidade de estudo que existe é verificar os aspectos expressos por combinações de perífrases. Aqui referimos alguns casos, principalmente de combinação da perífrase "estar + gerúndio" com perífrases inceptivas e terminativas (ver itens 8.10 a 8.14), mas não fizemos um estudo mais detalhado das possibilidades aspectuais de semelhantes combinações. Fica aqui a sugestão para futuros trabalhos.

Tendo falado sobre a expressão do aspecto pela flexão temporal e pelas perífrases que, como dissemos, mereceria particular atenção, passamos a falar dos demais recursos. Nós o faremos da forma mais sintética possível, apresentando o resultado das observações feitas, mas sem nenhuma pretensão de apresentar um estudo mais detalhado da questão. Nosso objetivo é, tão somente, não deixar de registrar informações úteis e necessárias à compreensão do problema da expressão do aspecto. 


\section{9 - Outros recursos de expressão do aspecto}

\section{1 - SEMANTEMA DO Verbo}

Ao falarmos sobre a expressão do aspecto pelas flexões verbais e pelas perífrases, falamos sobre numerosos casos em que o aspecto expresso sofre a influência do semantema verbal, que não cabe repetir aqui. Vimos que o fato do verbo ser télico ou atélico; ser um verbo de processo, de evento ou de estado (ou, de modo mais amplo, de situação estática); indicar uma situação que aceita ou não descontinuidade afeta o aspecto expresso por uma dada flexão verbal ou perífrase. Estes diferentes tipos de verbos permitem explicar a presença de diferentes noções aspectuais em casos formalmente idênticos.

Acrescentaremos algo a dois dos casos já citados. Comrie (1976, p.50, 51) diz que, quando temos perfectivo + estado, há sempre uma referência ao começo ou término do estado. Em Português, podemos dizer que, quando temos um verbo de situação estática (seja estado ou não) com aspecto perfectivo, temos sempre uma referência ao término da situação, pois neste caso temos sempre aspecto acabado. É isto que explica o fato dos pretéritos perfeito e mais-que-perfeito do indicativo marcarem sempre o aspecto acabado, com os verbos de estado e estáticos em geral (cf. itens 7.3 e 7.4).

Em segundo lugar, queremos ressaltar que, quando temos um verbo de evento com uma forma durativa, se o verbo não muda de sentido (como no exemplo 117), nem temos os efeitos de significado observados nas frases (114) a (116); forçosamente teremos uma interpretação iterativa ${ }^{1}$, embora nem sempre possamos falar em aspecto iterativo. Alguns exemplos deste fato podem ser vistos no estudo da perífrase vir + gerúndio (cf. item 8.5.4., exemplos 909 a 911) e também em outros casos, como com as perífrases de continuar e prosseguir (cf. item 8.9, onde afirmamos que aspecto durativo + evento $=$ iteratividade).

\footnotetext{
${ }^{1}$ Verkuyl (1972) observou o mesmo fato para o alemão. (VERKUYL, H. J. On the compositional nature of the aspects. Dordrecht: D. Reidel, 1972. (Foundations of language, 15).).
} 
Em frases do tipo de (1.273), com a duração marcada por adjunto adverbial, temos também a interpretação iterativa.

\subsection{Laura abriu a porta durante duas horas.}

Como esta não é a maneira mais natural de expressar a iteração, sempre que possível o falante muda o significado do verbo para evitar a interpretação iterativa. É o que acontece em (1.274), onde a tendência é dar à frase o significado de que a pessoa ficou com o rádio ligado durante meia hora, e não que ficou ligando-o e desligando-o durante a meia hora.

\subsection{Elvira ligou o rádio meia-hora.}

Além do tipo de influência do semantema do verbo a que aludimos acima, temos os casos em que o aspecto é expresso pelo radical do próprio verbo. Os verbos que expressam aspecto pelo radical são sempre verbos que, pelo menos quando estão nesta função, não indicam situações propriamente ditas. São verbos que apenas introduzem certos matizes semânticos e/ou marcam aspecto, e sempre servem de suporte às categorias verbais de tempo, modo, número e pessoa, enquanto as situações são indicadas: a) por outro verbo (constituindo então uma perífrase); b) por substantivos que aparecem como seus sujeitos ou objetos; ou adjetivos (se a situação for um estado ou condição do ser). Quando a situação é um estado pode ser representada também pelo verbo, normalmente no particípio.

Já explicamos no item 4.2.4, porque os verbos indicadores de processos e eventos não marcam aspecto durativo e pontual. No item 4.2.14, explicamos porque os verbos indicadores de situações inceptivas e terminativas não marcam aspecto inceptivo e terminativo. As colocações que fazemos parecem suficientes para deixar claro que as colocações de Câmara Jr. sobre a expressão do aspecto pelo semantema do verbo (cf. item 1.3.8) não são válidas, de acordo com nosso modo de ver o aspecto. Nestes casos, as situações é que são durativas, pontuais, inceptivas ou terminativas, o que é diferente de apresentar uma situação como tendo duração contínua limitada, sem duração, em seu momento de início ou término, ou em seus primeiros ou últimos momentos.

Abaixo apresentamos um quadro com os verbos que expressam aspecto pelo semantema, o aspecto indicado, os elementos que normalmente indicam a situação e as condições em que o verbo expressa o aspecto. Estas condições dirão respeito apenas aos casos em que a situação é expressa por substantivo ou adjetivo, uma vez que para as perífrases já fizemos o comentário no capítulo 8. Os exemplos dados estão no mesmo caso. 


\begin{tabular}{|c|c|c|c|}
\hline \multicolumn{4}{|c|}{ QUADRO VI } \\
\hline VERBOS & $\begin{array}{c}\text { ASPECTOS QUE } \\
\text { EXPRESSAM }\end{array}$ & $\begin{array}{l}\text { ELEMENTOS } \\
\text { INDICADORES } \\
\text { DA SITUAÇÃO }\end{array}$ & $\begin{array}{l}\text { CONDIÇÕES EM } \\
\text { QUE O ASPECTO } \\
\text { É EXPRESSO }\end{array}$ \\
\hline Estar & $\begin{array}{l}\text { Imperfectivo, cur- } \\
\text { sivo, não acabado } \\
\text { e durativo }\end{array}$ & Verbo ou adjetivo & $\begin{array}{l}\text { Em todas as flexões } \\
\text { verbais, exceto nos } \\
\text { pretéritos perfeito e } \\
\text { mais-que-perfeito do } \\
\text { indicativo, em que } \\
\text { só marca o durativo. } \\
\text { Exatamente como } \\
\text { na perífrase de es- } \\
\text { tar + particípio (item } \\
8.3 .3 \text {, em que vimos } \\
\text { que o particípio vale } \\
\text { por um adjetivo). } \\
\text { Exemplos: (1.275) } \\
\text { a (1.282), exceto as } \\
\text { frase b. }\end{array}$ \\
\hline Andar & $\begin{array}{l}\text { Imperfectivo, cur- } \\
\text { sivo, não acabado } \\
\text { e durativo }\end{array}$ & $\begin{array}{l}\text { Adjetivo ou equiva- } \\
\text { lente (como o par- } \\
\text { ticípio verbal, por } \\
\text { exemplo) }\end{array}$ & $\begin{array}{l}\text { Quando funciona } \\
\text { como verbo rela- } \\
\text { cional ou de ligação } \\
\text { em todas as flexões } \\
\text { verbais, exceto nos } \\
\text { pretéritos perfeito e } \\
\text { mais-que-perfeito do } \\
\text { indicativo, em que } \\
\text { só marca o durativo } \\
\text { e nas flexões verbais } \\
\text { de valor temporal } \\
\text { futuro, em que não } \\
\text { expressa nenhum } \\
\text { aspecto. Exemplos: } \\
(1.275 b),(1.279 b) \text { e } \\
(1.281 b) \text {. }\end{array}$ \\
\hline Viver & Habitual & Verbo ou adjetivo & $\begin{array}{l}\text { Nas condições já es- } \\
\text { pecificadas em } 8.6 .3 \text {, } \\
\text { quando falávamos } \\
\text { da perífrase "viver } \\
\text { + particípio". Exem- } \\
\text { plos: }(961),(1283) \text { e } \\
(1.284) \text {. }\end{array}$ \\
\hline Costumar & Habitual & Verbo & Veja item 8.6.4 \\
\hline Usar & Habitual & Verbo & Veja item 8.6.5 \\
\hline
\end{tabular}


Continuação da página 255

\begin{tabular}{|c|c|c|c|}
\hline VERBOS & $\begin{array}{l}\text { ASPECTOS QUE } \\
\text { EXPRESSAM }\end{array}$ & $\begin{array}{l}\text { ELEMENTOS } \\
\text { INDICADORES } \\
\text { DA SITUAÇÃO }\end{array}$ & $\begin{array}{c}\text { CONDIÇÕES EM } \\
\text { QUE O ASPECTO } \\
\text { É EXPRESSO }\end{array}$ \\
\hline Ficar & Iterativo & Verbo & $\begin{array}{l}\text { Veja item } 8.7, \\
\text { quando o verbo } \\
\text { ficar tem o terceiro } \\
\text { significado. }\end{array}$ \\
\hline Ficar & Durativo & Verbo ou adjetivo & $\begin{array}{l}\text { Nas condições já } \\
\text { especificadas no } \\
\text { item } 8.7 \text {, quando o } \\
\text { verbo "ficar" tem } \\
\text { o primeiro signi- } \\
\text { ficado. Exemplos } \\
(1.285) \text { a }(1.287) \text {. }\end{array}$ \\
\hline Continuar & $\begin{array}{l}\text { Começado, } \\
\text { durativo }\end{array}$ & $\begin{array}{l}\text { Verbo ou } \\
\text { substantivo }\end{array}$ & $\begin{array}{l}\mathrm{N} \text { a } \mathrm{s} \text { e } \mathrm{s} \mathrm{m} \text { a } \\
\text { condições já espe- } \\
\text { cificadas em } 8.9 \text {. } \\
\text { Exemplos: }(1.288) \\
\text { a }(1.291) .\end{array}$ \\
\hline Prosseguir & $\begin{array}{l}\text { Começado, } \\
\text { durativo }\end{array}$ & $\begin{array}{l}\text { Verbo ou } \\
\text { substantivo }\end{array}$ & $\begin{array}{l}\mathrm{N} \text { a } \mathrm{s} \text { e s m a s } \\
\text { condições já espe- } \\
\text { cificadas em } 8.9 \text {. } \\
\text { Exemplos: }(1.292) \\
\text { a }(1.295) .\end{array}$ \\
\hline Acabar & Terminativo & $\begin{array}{l}\text { Verbo ou } \\
\text { substantivo }\end{array}$ & $\begin{array}{l}\text { Nas mesmas } \\
\text { condições já } \\
\text { especificadas } \\
\text { em } 8.12 .2 \text { para a } \\
\text { perífrase "acabar } \\
+ \text { de }+ \text { infinitivo } \\
\text { (ex e m } 1 \text { o s: } \\
1.296 \text { e } 1.297 \text { ) } \\
\text { Nos presentes } \\
\text { do indicativo } \\
\text { e subjuntivo } \\
\text { em descrições } \\
\text { sim ut ân a s } \\
\text { (exemplo } 1.298 \text { ) } \\
\text { nos pretéritos } \\
\text { imperfeito do } \\
\text { indicativo e do } \\
\text { subjuntivo com } \\
\text { um elemento } \\
\text { presentificador } \\
\text { (exemplos } 1.299 \text { e } \\
\text { 1.300). }\end{array}$ \\
\hline
\end{tabular}




\begin{tabular}{|c|c|c|c|}
\hline \multicolumn{4}{|r|}{ Continuação da página 256} \\
\hline VERBOS & $\begin{array}{c}\text { ASPECTOS QUE } \\
\text { EXPRESSAM }\end{array}$ & $\begin{array}{l}\text { ELEMENTOS } \\
\text { INDICADORES } \\
\text { DA SITUAÇÃO }\end{array}$ & $\begin{array}{c}\text { CONDIÇÕES EM } \\
\text { QUE O ASPECTO } \\
\text { É EXPRESSO }\end{array}$ \\
\hline Terminar & Terminativo & $\begin{array}{l}\text { Verbo ou } \\
\text { substantivo }\end{array}$ & $\begin{array}{l}\text { Nas mesmas } \\
\text { c o ndições já } \\
\text { e specificadas } \\
\text { em } 8.13 .2 \text { para a } \\
\text { perífrase "terminar } \\
+ \text { de + infinitivo". } \\
\text { Exemplos (1.301) } \\
\text { a (1.304). }\end{array}$ \\
\hline Começar, principiar & Inceptivo & $\begin{array}{l}\text { Verbo ou } \\
\text { Substantivo }\end{array}$ & $\begin{array}{l}\text { Nas mesmas } \\
\text { c ondições já } \\
\text { especificadas em } \\
8.14 .1 \text { para as } \\
\text { perífrases "começar } \\
+ \text { a + infinitivo" } \\
\text { e "principiar + } \\
\text { a + infinitivo". } \\
\text { Exemplos: (1.305) } \\
\text { a (1.309). }\end{array}$ \\
\hline $\begin{array}{l}\text { Iniciar, } \\
\text { iniciar-se }\end{array}$ & Inceptivo & Substantivo & $\begin{array}{l}\text { Nas mesmas } \\
\text { c o n d i ç õ e s } \\
\text { especificadas } \\
\text { para "começar" } \\
\text { e "principiar" } \\
\text { acima. Exemplos: } \\
(1.310) \text { a (1.315). }\end{array}$ \\
\hline Ser & Indeterminado & $\begin{array}{l}\text { Adjetivo ou } \\
\text { equivalente e } \\
\text { substantivo em } \\
\text { função atributiva }\end{array}$ & $\begin{array}{l}\text { Com todas as } \\
\text { flexões verbais. } \\
\text { Ex e m p lo s : } \\
(1.316) \text { a }(1.321) \text {. } \\
\text { Para a perífrase } \\
\text { "ser + de + } \\
\text { infinitivo", veja } \\
8.15 .3 \text {. }\end{array}$ \\
\hline
\end{tabular}


Exemplos:

1.275. a - Seu irmão está elegante.

b - Seu irmão anda triste ultimamente.

1.276. Na festa ele estava todo feliz.

1.277. O vaso estará lindo quando você vier buscá-lo.

1.278. A casa estaria suja se eu não a tivesse limpado.

1.279. a - Embora Joel esteja tão amável, não consigo acreditar em sua amabilidade.

b - Embora Joel ande tão amável, não consigo acreditar em sua amabilidade.

1.280. Estar apto para o trabalho é um dever de vocês, o que vamos verificar é quem está mais apto.

1.281. a - Essa casa esteve limpa.

b - João andou preocupado estes dias.

1.282. $\mathrm{O}$ artista estivera inigualável em sua apresentação e se sentia satisfeito.

Em (1.275) a (1.280), temos os aspectos imperfectivo, cursivo, não acabado, durativo; em (1.281) e (1.282), o perfectivo, o acabado e o durativo. Parece haver restrição ao uso de "andar" como relacional e marcador de aspecto em vários tempos flexionais.

1.283. Mariazinha vivia suja. (imperfectivo, não acabado, habitual).

1.284. Embora meu irmão viva impaciente com os funcionários não os trata mal. (imperfectivo, não acabado, habitual).

1.285. Se eu lhe der uma bala, você fica bonzinho até sua mãe voltar? (durativo).

1.286. Por sua causa, Laura ficou triste o dia todo. (perfectivo, durativo).

1.287. Naquele dia, ele me disse que ficasse pura, como eu era, por toda a vida. (durativa).

1.288. A festa continua animada. (imperfectivo, cursivo, começado, durativo).

1.289. Como os dois países não assinaram o tratado de paz, a guerra continua. (imperfectivo, cursivo, começado, durativo).

1.290. A disputa continuou até à tarde. (começado, durativo - estes aspectos se referem à S.N. expressa pelo substantivo disputa; a S.R. de "continuar a disputa" tem aspecto perfectivo). 
1.291. Embora Laerte continue triste, já está mais conformado. (imperfectivo, cursivo, não acabado, durativo).

1.292. O torneio prossegue sem muitas novidades. (imperfectivo, cursivo, não acabado, durativo).

1.293. Quando voltamos à sala, a discussão prosseguia. (imperfectivo, cursivo, não acabado, durativo).

1.294. A disputa prosseguiu até tarde. (idem ao exemplo 1.290).

1.295. Embora a guerra prossiga, há esperanças de que os dois países façam um acordo de paz. (imperfectivo, cursivo, não acabado, durativo).

1.296. César está acabando o trabalho. (imperfectivo, terminativo, não acabado).

1.297. Se você demorar muito o baile estará acabando quando chegarmos lá. (imperfectivo, terminativo, não acabado).

1.298. A corrida acaba (= está acabando) numa disputa acirrada pelo primeiro lugar. (imperfectivo, terminativo, não acabado).

1.299. Quando entramos no campo a partida acabava. (imperfectivo, terminativo, não acabado).

1.300. Embora o baile acabasse quando chegamos, ainda pudemos nos divertir um pouco. (imperfectivo, terminativo, não acabado).

1.301. - O que você está fazendo?

- Termino o trabalho que tenho de entregar amanhã. (imperfectivo, terminativo, não acabado).

1.302. Quando chegamos à fazenda, os peões terminavam a colheita. (imperfectivo, terminativo, não acabado).

1.303. Embora a procura esteja terminando, ainda não encontramos nenhum espécimen desconhecido. (imperfectivo, terminativo, não acabado).

1.304. A discussão terminou quando soou a campainha, anunciando o final da aula. (terminativo e acabado - estes aspectos se referem à S.N. expressa pelo substantivo discussão. A situação de "terminar a discussão" tem aspectos perfectivo e acabado).

1.305. A festa começa e todos já demonstram muita animação. (imperfectivo, inceptivo, começado).

1.306. Quando fomos à oficina Hugo começava o trabalho. (imperfectivo, inceptivo, começado).

1.307. A guerra começou no dia 3 de julho de 1972.

a - S.R.: começar a guerra - perfectivo, acabado.

b - S.N.: expressa pelo substantivo guerra - começado, inceptivo. 
1.308. Quando chegarmos à fazenda, o pessoal estará começando a plantação. (imperfectivo, inceptivo, começado).

1.309. Embora greve apenas começasse, já se percebia que não duraria muito. (imperfectivo, inceptivo, começado).

1.310. O torneio inicia-se e há grande expectativa entre as diversas equipes. (imperfectivo, inceptivo, começado).

1.311. Há dois dias, os presidentes dos clubes iniciavam as conversações que resultaram no documento apresentado hoje à CBD. (imperfectivo, inceptivo, começado).

1.312. A festa se iniciou exatamente às quatorze horas. a - S.R.: iniciar a festa - perfectivo, acabado.

b - S.N.: expressa pelo substantivo festa - inceptivo, começado.

1.313. Às dez horas o debate estará se iniciando e deverá acabar até o meio dia. (imperfectivo, inceptivo, não acabado).

1.314. Embora o inquérito apenas se inicie, muita gente já está em dificuldades para provar sua inocência. (imperfectivo, inceptivo, começado).

1.315. Mesmo que a epidemia estivesse se iniciando, seria muito difícil controlá-la. (imperfectivo, inceptivo, começado).

1.316. Maria é bondosa. (imperfectivo, não acabado, indeterminado).

1.317. João era feliz quando morava aqui. (imperfectivo, não acabado, indeterminado).

1.318. Isá foi professor a vida toda. (perfectivo, acabado, indeterminado).

1.319. Meu filho será um agricultor como eu. (indeterminado).

1.320. Embora Rui seja alto, não se aproveita disso no jogo. (imperfectivo, não acabado, indeterminado).

1.321. Se Jorge for realmente um médico, não deixará de socorrer você. (imperfectivo, não acabado, indeterminado).

OBS. - O verbo ser marca o aspecto indeterminado, porque expressa sempre estado permanente, isto é, de duração contínua ilimitada.

Os exemplos apresentados neste item nos mostram que, mesmo quando a situação é expressa por um substantivo ou adjetivo, o aspecto se concentra no verbo, mesmo que este tenha a única função de servir de suporte às categorias verbais, sem indicar qualquer situação. 
É interessante observar ainda que não temos aspectos inceptivo e terminativo com verbos de estado. Isto parece se dar porque a língua expressa o início dos estados lexicalmente por outros verbos (como adoecer, sarar, endurecer, emagrecer etc.), ou pelo verbo "ficar + estado" (ficar doente, ficar feliz etc.). Quanto ao final do estado deve-se ter em mente o que comentamos logo após o quadro II, no item 3.2, onde dizemos que o final de um estado é sempre o início de outro e que a língua centra-se no estado que começa. A única possibilidade de termos inceptivo e terminativo com verbos de estado seria em frases do tipo de (1.322) e (1.323) abaixo.

1.322. João começa a estar doente. (feliz, preocupado, etc.). (imperfectivo, inceptivo, não acabado).

1.323. a - * João termina de estar doente. (feliz, preocupado, etc.). b - ?*João está deixando de estar doente. (feliz, preocupado, etc.).

Embora tais frases sejam possíveis pelo código linguístico do Português, os falantes veem frases do tipo de (1.323) como inaceitáveis e, embora achem possíveis frases como (1.322), afirmam que não as usariam, porque não são usadas habitualmente. As frases inceptivas com "ser" são mais aceitáveis e inclusive usadas (exemplo 1.324), mas as terminativas continuam inaceitáveis (exemplo 1.325 a).

A restrição parece ser porque um estado, bem como outras situações estáticas do tipo de amar e respirar (exemplo 1.325 c) não terminam propriamente, mas cessam sem atingir um ponto terminal. Daí termos frases mais aceitáveis quando empregamos perífrases de valor mais cessativo (cf. nota 135). Exemplos (1.325 b) e $(1.325 \mathrm{~d})$. Todavia as frases com outros verbos de estado que não o verbo "ser" continuam muito estranhas (exemplo $1.323 \mathrm{~b}$ ).

1.324. Raul começa a ser feliz. (imperfectivo, não acabado, inceptivo).

1.325. a - * Raul termina de ser feliz. (ou "* está terminando de ser feliz").

b - Raul está deixando de ser feliz. (imperfectivo, não acabado, terminativo).

c - * Raul termina de respirar. (ou “* está terminando de respirar").

d - Raul está deixando de respirar. (imperfectivo, não acabado, terminativo). 


\section{2 - Adjuntos ADVERbiais}

Não há qualquer dúvida quanto ao fato de que os adjuntos adverbiais têm muito a ver com o aspecto. Alguns estudiosos notaram esta relação. Assim por exemplo, Verkuyl (1.972, p.8) afirma que qualquer tentativa de descrever sentenças que contêm advérbios de tempo, não pode ignorar o aspecto. Castilho (1.967) aponta numerosos exemplos em que o adjunto adverbial seria o responsável pelo aspecto presente na frase. Este autor anota ainda que os adjuntos adverbiais envolvidos na expressão do aspecto são sempre temporais.

No estudo da expressão do aspecto pelas flexões verbais e pelas perífrases, arrolamos os principais casos de atuação dos adjuntos adverbiais neste particular. Desnecessário, pois, repeti-los aqui. O que faremos será, tão somente, apresentar alguns delineamentos gerais.

Os aspectos em cuja expressão os adjuntos adverbiais atuam são o iterativo, o habitual, o durativo, o inceptivo, o terminativo e o acabado.

Observamos que os adjuntos adverbiais, envolvidos na expressão do aspecto em Português, exercem sempre uma de três funções:
a. evitar ambiguidades;
b. marcar o aspecto por si ou em combinação com outro elemento;
c. reforçar um aspecto expresso por outro elemento, tornando-o mais patente.

Apenas para facilidade do leitor, remeter-nos-emos a alguns dos casos já estudados. $\mathrm{O}$ adjunto adverbial evita ambiguidade, por exemplo, na expressão do habitual pelo pretérito imperfeito do indicativo (cf. comentários em torno dos exemplos 364 a 369).

$\mathrm{O}$ adjunto adverbial marca o aspecto por si, por exemplo, quando marca o acabado com o presente do indicativo (cf. o exemplo 318 e comentários); ou quando marca o durativo (cf. exemplos 354 a 356 e comentários), o iterativo (exemplos 358 e 359) ou o habitual (exemplo 360) com o pretérito perfeito do indicativo. Em combinação com outro elemento o adjunto adverbial marca, por exemplo, o aspecto inceptivo e terminativo, respectivamente com as perífrases "começar + a + infinitivo" e "terminar + de + infinitivo" nos futuros e nos pretéritos perfeito e mais-que-perfeito do indicativo (cf. exemplos 1.171 a 1.175, $1.176,1.200$ a 1.202, 1.204 e comentários).

É comum o adjunto adverbial reforçar o aspecto já expresso por outro 
elemento. Isto ocorre, por exemplo, com os aspectos iterativo e habitual expresso pelo pretérito imperfeito do indicativo (cf. exemplo 372 e comentário) e o presente do indicativo. Ocorre também com um adjunto adverbial que marca duração e uma perífrase durativa. São exemplos disso as frases (1.014), (1.015), (1.017), (1.018) com as perífrases de ficar e (1.051) a (1.056), (1.058) com as perífrases de permanecer.

Os adjuntos adverbiais que atuam na expressão do aspecto são quase sempre de tempo ou frequência. ${ }^{2}$ Um caso que foge a esta colocação é o do exemplo (709 b), em que a ambiguidade existente no exemplo (709 a) desaparece pela influência do adjunto adverbial de lugar "nas reuniões" que, no entanto, é facilmente convertível em adjunto adverbial de tempo.

O advérbio "já" parece sempre reforçar o perfectivo e o acabado quando utilizado com formas que marcam estes aspectos. Por outro lado, o advérbio "ainda" parece fazer o mesmo com o imperfectivo e o não acabado. Veja exemplos (1.326) e (1.327).

1.326. Fernando já bebeu a laranjada.

1.327. Zulmira ainda vende roupas feitas.

É comum, nas frases com "já", a ideia de experienciamento (cf. o exemplo 84 e o exemplo 1.328 abaixo).

1.328. Eu já andei de montanha russa.

É interessante observar que os adjuntos adverbiais que expressam progressividade (aos poucos, pouco a pouco, cada vez mais etc.) sempre marcam (cf. exemplo 71) ou reforçam (ver exemplo 1.329 abaixo) o durativo.

1.329. Leila foi comprando o material aos poucos para depois construir a casa (perfectivo, durativo).

É importante lembrar também que os adjuntos adverbiais de frequência do tipo de sempre, todos os dias, às vezes, várias vezes, muitas vezes (e outros em "vez"), aos domingos, normalmente, diariamente, raramente,

\footnotetext{
${ }^{2}$ Bonfim (1976) afirma que advérbios como "sempre", "várias vezes", etc. são advérbios de frequência e não de tempo, com o que concordamos. (BONFIM, E. do R. M. Contribuição ao estudo do advérbio. 1976. 90 p.Tese (Livre-docência) - Departamento de Letras e Artes, Pontifícia Universidade Católica do Rio de Janeiro, Rio de Janeiro, 1976.).
} 
de tempos em tempos, em combinação com o presente e pretérito imperfeito do indicativo e do subjuntivo, levam, quase sempre, à expressão do habitual e, mais raramente, à expressão do iterativo. Vejam-se os comentários feitos sobre estes adjuntos adverbiais no item 4.2.6.

Outro tipo de relação observada entre os adjuntos adverbiais e os aspectos é que os segundos (principalmente o imperfectivo e o perfectivo) condicionam a interpretação que se pode dar aos primeiros (cf. exemplos 166 a 170 e 349 a 351 com os respectivos comentários). Há também uma seleção entre os aspectos durativo e pontual e os adjuntos adverbiais que expressam duração e pontualidade (cf. comentários no item 4.2.8). Não nos detivemos no estudo da seleção entre aspecto e adjuntos adverbiais. Fica aqui a sugestão para trabalhos futuros.

$\mathrm{O}$ adjunto adverbial também pode afetar o aspecto, na medida em que pode fazer um verbo atélico tornar-se télico (cf. comentários em torno do exemplo 96 no item 3.1).

Veja também o que comentamos no final do item 9.3.1 adiante.

\section{3 - Afixos}

Ao contrário de algumas línguas, como as eslavas, em que os afixos são de grande importância na expressão dos aspectos, o português não tem afixos que os expressem.

\subsection{1 - PREFIXOS}

Garcia (1976, p.60) afirma que o prefixo RE- marca iteração, que seria um aspecto (cf. item 1.3.7). Castilho (1967, p.61, nota 111) comenta que, a seu ver, os prefixos portugueses não indicam aspecto.

Neste ponto, estamos de acordo com Castilho. O único prefixo que poderia marcar aspecto seria RE- por expressar repetição da situação, o que caracterizaria o aspecto iterativo: reler, retransmitir, rever, etc. Entretanto não temos aqui o aspecto iterativo porque, como explicamos para as perífrases "tornar ou voltar + a + infinitivo", apesar de haver repetição da situação, os verbos formados com este prefixo se referem apenas a uma realização da situação e não lhe atribuem, portanto, uma duração descontínua. $\mathrm{O}$ aspecto destes verbos dependerá da flexão verbal e outros fatores.

Pela mesma razão exposta para o prefixo RE-, os elementos adverbiais de novo, novamente e outra vez não expressam aspecto iterativo. 


\subsection{2 - SUFIXOS}

Vários autores apontam sufixos portugueses como expressando aspecto: Luft (1976, p.131) (cf. item 1.3.5), Garcia (1976, p.60) (cf. item 1.3.7), Câmara Júnior (1974a, p.86) (cf. item 1.3.8) e Castilho (1967, p.114).

\begin{tabular}{l|l|l|l|l}
\hline & \multicolumn{1}{|c|}{ LUFT } & \multicolumn{1}{c|}{ GARCIA } & CÂMARA JR. & \multicolumn{1}{c}{ CASTILHO } \\
\hline -EJAR & iterativo & & iterativo & $\begin{array}{l}\text { inceptivo } \\
\text { incoativo, } \\
\text { iterativo }\end{array}$ \\
\hline -ITAR & iterativo & & iterativo & iterativo \\
\hline -ECER & incoativo & inceptivo & inceptivo & $\begin{array}{l}\text { inceptivo } \\
\text { incoativo, } \\
\text { inceptivo, } \\
\text { iterativo }\end{array}$ \\
\hline
\end{tabular}

São os seguintes os sufixos normalmente apresentados como marcadores de aspecto. ${ }^{3}$

incoativo $=$ inceptivo

Exemplos:

1.330. a - ejar (iterativo): voejar, gotejar.

b - ejar (inceptivo): fraquejar, palejar.

1.331. -itar (iterativo): saltitar, dormitar.

1.332. -ecer (inceptivo): amanhecer, enriquecer, endurecer.

Diz-se que os sufixos -EJAR e -ECER marcam aspecto inceptivo quando formam verbos incoativos. Já dissemos no item 2.3 que os autores fazem tal afirmação porque os verbos incoativos são verbos de situações inceptivas, isto é, situações cuja realização implica o começo de uma outra situação. Os incoativos implicam o início de um novo estado. ${ }^{4}$ Já argumentamos (cf. itens 4.2.14 e 9.1) que tais verbos não expressam aspecto inceptivo, porque, ao utilizá-los, não estamos apresentando os estados em seu momento de início ou em seus primeiros momentos, estamos

\footnotetext{
${ }^{3}$ Castilho (1.967) cita outros sufixos iterativos. Não os enumeramos, pois o raciocínio que será feito vale também para eles.

${ }^{4}$ Às vezes o verbo incoativo não marca o início de um novo estado. É o caso de “amanhecer”, por exemplo.
} 
sim apresentando a situação cuja realização levará a um dado estado. Esta situação pode ter qualquer aspecto inclusive o terminativo (cf. exemplo 1.333).

1.333. A massa está terminando de endurecer. (imperfectivo, terminativo, não acabado).

Se admitíssemos que os verbos incoativos marcam aspecto inceptivo, teríamos que afirmar o mesmo do verbo "ficar" no sentido de "tornar-se, vir a estar em determinada situação" (cf. item 8.7).

Como os verbos incoativos não marcam o inceptivo ${ }^{5}$, os sufixos -EJAR e -ECER, responsáveis pela incoação, não expressam esse aspecto como normalmente se diz.

Raciocínio semelhante pode ser feito para os sufixos -EJAR e -ITAR que marcariam o iterativo. Esses sufixos e outros formam verbos que expressam situações intrinsecamente iterativas (cf. o que dizemos no item 4.2.6) e, normalmente, com ideia de diminuição. Por esta razão se diz que os sufixos formadores de tais verbos expressam aspecto iterativo. Agora perguntamos: ao usar verbos como saltitar, cuspinhar, voejar estamos nos referindo às situações de saltar, cuspir e voar atribuindo a estas uma duração descontínua limitada? É evidente que não. Estamos nos referindo a outras situações, constituídas pela repetição diminutiva destas últimas, sendo que as primeiras podem ser apresentadas ou não com aspecto iterativo, como mostramos nos exemplos (191) a (196) e como se pode ver em (1.334) e (1.335).

1.334. As borboletas estão voejando de flor em flor. (imperfectivo, cursivo, não acabado, durativo).

1.335. O filhote de que estamos tratando anda voejando e não demora a voar, indo morar com os seus na floresta. (imperfectivo, não acabado, iterativo).

Não nos parece válido pois, que, ao utilizarmos verbos como saltitar, cuspinhar, voejar e repicar, afirmemos que eles expressam aspecto iterativo, pensando na repetição de saltar, cuspir, voar e picar. Esta é, na verdade, um sema do significado daqueles verbos, o que é muito diferente de, gramaticalmente, apresentar estas últimas situações como repetidas em consequência de sua duração descontínua limitada. Assim sendo, os sufixos em questão, responsáveis por tal valor iterativo, na realidade não expressam aspecto.

\footnotetext{
${ }^{5}$ É comum termos a ideia de progressão com os verbos incoativos, quando estes têm aspecto imperfectivo.
} 


\section{4 - O TIPO ORACIONAL}

As orações podem concorrer para a expressão, alteração do aspecto ou para tornar mais patente o aspecto expresso. A maioria das orações que interferem com o aspecto são orações subordinadas adverbiais temporais, mas outros tipos podem também atuar.

Vimos que as orações temporais (normalmente iniciadas por quando, sempre que, cada vez que além de outras conjunções e locuções conjuntivas) levam o verbo ou perífrase verbal da oração em que exercem a função de adjunto adverbial a ter aspecto habitual, quando está no presente e pretérito imperfeito do indicativo e do subjuntivo. ${ }^{6}$ Para que isto ocorra, é preciso que o verbo da oração temporal esteja no presente do indicativo (se o verbo da outra estiver no presente do indicativo ou do subjuntivo) e no pretérito imperfeito do indicativo (se o verbo da outra estiver no pretérito imperfeito do indicativo ou do subjuntivo). Exemplos com verbos simples na principal podem ser observados em (1.336) a (1.339). Com perífrases verbais temos muitos exemplos no capítulo 8 (ver por exemplo, as frases 863,875 , $1.005,1.007,1.022$, 1.035, 1.038, 1.065, 1.066, 1.091, 1.092, 1.102, 1.106, 1.116, $1.169,1.170,1.198)$.

1.336. Seu primo só vem aqui, quando precisa de algo. (imperfectivo, não acabado, habitual).

1.337. Embora ele adoeça quando toma muito sol, adora ficar horas na praia. (imperfectivo, não acabado, habitual).

1.338. Minha filha chorava sempre que me via na televisão. (imperfectivo, não acabado, habitual).

1.339. Embora Marcelo me visitasse quando vinha a Uberlândia, nunca demorava mais de meia-hora. (imperfectivo, não acabado, habitual).

Quando a oração principal tem o verbo no pretérito imperfeito do indicativo ou do subjuntivo, se a oração temporal tiver o verbo no pretérito perfeito do indicativo, os aspectos cursivo e durativo, indicados por aqueles tempos, se tornam

\footnotetext{
${ }^{6}$ Castilho $(1.967$, p.60) observa que a iteração pode ser expressa por orações subordinadas de valor condicional temporal e apresenta o seguinte exemplo:

"Quando ela chama nós respondemos".

Nas páginas 98 a 100 o autor apresenta outros exemplos.

Castilho vê iteração no verbo das duas orações. Parece-nos que a habitualidade está apenas no verbo da principal, que expressa uma situação cuja habitualidade está condicionada pela temporal: é habitual responder quando ela chama, mas não se expressa se é habitual ela chamar.
} 
mais patentes. Veja os exemplos (361) e (362) e comentários feitos no item 7.3 para o pretérito imperfeito do indicativo, e os exemplos (469) e (541) para o pretérito imperfeito do subjuntivo.

A exemplo dos adjuntos adverbiais, as orações adverbiais, especialmente as iniciadas pela conjunção enquanto, marcam o aspecto durativo, com o verbo nos prets. perfeito e mais-que-perfeito do indicativo. Veja exemplos (356) e (1340), (1.341) abaixo.

1.340. Samuel esperou pelo amigo até que vieram the dizer que iam fechar o bar. (perfectivo, durativo).

1.341. Conversou comigo enquanto almoçava. (perfectivo, durativo).

Vimos também que as orações adverbiais temporais podem reforçar o aspecto durativo, tornando-o mais patente, com as perífrases "ficar + gerúndio", "ficar + particípio", "ficar + por + infinitivo", "permanecer + gerúndio" e "permanecer + particípio". Veja os exemplos 1.011, 1.017, 1.024 a 1.057 nos itens 8.7 e 8.8 .

Vimos que as orações subordinadas adjetivas parecem criar uma tendência para o imperfectivo e o habitual ou o indeterminado, levando o presente e o pretérito imperfeito do subjuntivo de seus verbos a expressarem tais aspectos (cf. os exemplos 554 a 558 e os comentários feitos após os mesmos). O mesmo efeito se verifica com o presente e o pretérito imperfeito do indicativo (cf. exemplos 1.342 e 1.343 abaixo).

1.342. O homem que cumpre seu dever nada tem a temer. (imperfectivo, não acabado, habitual).

1.343. A firma que comprava nossas laranjas faliu. (imperfectivo, não acabado, habitual).

Como já foi dito, a decisão entre habitual e indeterminado é, às vezes, muito difícil.

Apesar da tendência para o habitual e o indeterminado, podemos ter o durativo nas orações adjetivas. Exemplo:

1.344. Sr. Presidente, por favor atenda as pessoas que esperam na sala. (imperfectivo, cursivo, não acabado, durativo).

Vimos também, no item 7.8.2, que nas orações adjetivas reduzidas de gerúndio, esta forma nominal expressa aspecto por influência do tipo oracional (cf. 
exemplos 622 a 625). De um modo geral, observamos que o aspecto que se pode considerar atualizado pelo gerúndio depende muito do tipo oracional em que a oração reduzida de gerúndio pode ser desenvolvida.

As orações subordinadas adverbiais proporcionais parecem reforçar o durativo expresso por suas formas verbais e pelas da oração principal (exemplos 1.345 a 1.347). Quando o verbo da principal está no pretérito perfeito ou mais-que-perfeito do indicativo a oração proporcional parece ser a responsável pelo aspecto durativo que ele possa ter. Isto parece se dar também com o próprio verbo da proporcional (exemplo 1.348).

1.345. À proporção que avançávamos, as casas iam rareando.

1.346. A inundação aumentava à medida que subiam as águas do rio.

1.347. As ânsias foram serenando à medida que tudo se esclarecia.

1.348. Seu Antônio ganhou experiência à medida que envelheceu e não de uma hora para outra, como você quer. (perfectivo, durativo).

Isto se dá sempre que temos orações proporcionais. É interessante notar que nas orações proporcionais existe uma tendência para apresentar o verbo, seu e da principal, no presente e no pretérito imperfeito do indicativo. Isto talvez se explique pelo valor progressivo apresentado por este tipo de oração e que é mais natural com tais tempos flexionais.

O iterativo pode ser marcado pelas orações coordenadas alternativas com ora...ora em frases como (1.349) a (1.351).

1.349. José ora se entristecia, ora se alegrava sem motivo aparente para tais mudanças.

1.350. As crianças ora choram, ora brincam; mas não dão muito trabalho.

1.351. Ora você o odiará, ora o amará, pois em determinados momentos ele é um demônio, noutros um anjo.

Em frases com o verbo no presente do indicativo (como 1.350), parece que temos o habitual e não o iterativo simples.

Castilho (1.967, p.100) anota que o predicado composto ligado por e parece exercer influência na expressão da repetição e apresenta os seguintes exemplos:

1.352. "O menino mais velho, passada a primeira vertigem, $[\ldots]$ adormecia e acordava". - (G. Ramos) 
1.353. Vedes, além, na Estrada de Santiago, aquela estrelinha a luzir e a apagar-se como candeia ao vento?" - (A. Ribeiro)

Realmente temos aspecto iterativo nos dois casos, mas este se deve antes ao sentido alternativo que há na construção do que a ela em si, pois, se tivermos esse "predicado composto" sem o sentido alternativo, não teremos o iterativo, como se pode ver em (1.354).

1.354. Quando entrei no escritório, Celso almoçava e lia o jornal para não perder tempo. (imperfectivo, cursivo, não acabado, durativo - para os dois verbos).

\section{5 - A REPETIÇÃo do VERBo}

Como vimos no item 7.3, a repetição do verbo no pretérito perfeito do indicativo marca o aspecto durativo, a exemplo do que ocorre nas frases (139), (140), (265), (357) e (1.355) abaixo, em que o verbo é repetido com "que" intermediário.

1.355. "E foram que foram, andaram que andaram e chegaram na casa do pai de São Francisco.” - (O. E. Xidieh) $)^{7}$ (perfectivo, durativo).

A repetição do verbo pode marcar o durativo também com outros tempos flexionais. Exemplos:

1.356. O menino correra, correra e depois ficara à sombra de uma árvore descansando.

1.357. Você trabalhará, trabalhará para no fim não ter nada.

1.358. Mesmo que pensasse, pensasse e pensasse, não conseguiria saber o que fazer.

Com o verbo no presente e pretérito imperfeito do subjuntivo e principalmente do indicativo, é comum ter-se o habitual. Neste caso, a situação que se repete é vista como durativa. Exemplos:

\footnotetext{
${ }^{7}$ Exemplo apud Castilho (1.967, p.72). Castilho apresenta este exemplo e uma série de outros com o verbo repetido, entre os exemplos de frases com aspecto Imperfectivo Cursivo Propriamente Dito. Para ele a repetição do verbo é apenas um recurso de ampliação da duração, mas não um recurso de expressão de qualquer aspecto.
} 
1.359. Você fala, fala, fala; mas na hora de agir não faz nada.

1.360. Toda noite ele lia, lia, lia e só bem tarde é que ia dormir.

Observe-se que o verbo repetido expressa também uma certa intensificação da situação.

Castilho (1.967, p.96, $\S 87 \mathrm{a}$, nota 138 ) observa que a iteração pode ser expressa pela repetição do verbo, e que exemplos como o de IMBS (1.960, p.55) (cf. exemplo 1.361), em que o futuro expressa repetição, devem ser explicados, dizendo que o futuro repetido expressa iteração e não o futuro em si.

1.361. "Je leur ai donné mon pain: la belle avance! Ils auront faim ce soir, ils auront faim demain!". 8

Castilho, à mesma página, dá o seguinte exemplo:

1.362. "Pois é, Sr. Doutor, meu irmão, bato-lhe à mesma. Bato na mulher, bato na criança, bato no cão." - V. Ferreira.

E diz que aí teríamos aspecto iterativo devido à repetição do verbo. Temos certa reserva em aceitar tal colocação, pois nos parece que tal repetição não marca aspecto iterativo nem numa frase como a da nota 149, resultante da tradução de (1.361), nem em (1.362). Nesta, considerando que o presente do indicativo não tenha valor de futuro no contexto em que se achava a frase, temos aspectos imperfectivo, não acabado e habitual, para cada ocorrência do verbo bater, mas aí o habitual se deve não à repetição do verbo, mas ao presente do indicativo. Pode-se verificar que a habitualidade não se deve à repetição do verbo confrontando-se o exemplo anterior com (1.363).

1.363. Sim, doutor, eu bato na minha mulher. (imperfectivo, não acabado, habitual).

\section{6 - ÊNFASE ENTONACIONAL}

Como vimos no item 7.3, os verbos estáticos (entre eles os de estado) e os verbos atélicos, no pretérito imperfeito do indicativo, marcam o aspecto acabado, quando, na língua falada, são enfatizados entonacionalmente dentro da frase.

8 “Eu lhes dei meu pão: grande vantagem! Eles terão fome esta noite, eles terão fome amanhã!" 


\section{7 - Preposições}

Em alguns casos, as preposições parecem influir na expressão de certas noções aspectuais e mesmo ser responsáveis pela atualização da categoria em outros.

A preposição A, quando utilizada com o infinitivo, parece ser a responsável pelos aspectos imperfectivo, cursivo, não acabado e durativo em casos como os exemplificados em (1.364 a), (1.365 a), (1.367) e (1.368). Em alguns casos, dependendo do verbo, temos o iterativo no lugar do cursivo e do durativo (como em 1.366a). Observando (1.364 b) a (1.366 b), em que a preposição foi retirada, vemos que a noção aspectual desapareceu, o que parece confirmar que é a preposição a responsável por sua presença nas frases a. Nas frases b, temos só a ideia de futuro.

1.364. a - Vou a ler o livro pelo caminho. ${ }^{9}$ (imperfectivo, cursivo, não acabado, durativo).

b - Vou ler o livro pelo caminho. (futuro).

1.365. a - José ia pela rua a pensar no problema, quando o chamaram. (imperfectivo, cursivo, não acabado, durativo).

b - José ia pensar no problema, quando o chamaram. (futuro iminência de ação).

1.366. a - Vou a perguntar por meu filho. (imperfectivo, não acabado, iterativo).

b - Vou perguntar por meu filho. (futuro).

1.367. A falar ele entrou na sala. (imperfectivo, cursivo, não acabado, durativo).

1.368. Quando cheguei em casa encontrei-o a beber. (imperfectivo, cursivo, não acabado, durativo).

Além destes casos, observando as perífrases que diferem apenas pela preposição que entra na sua formação, podemos dizer que, de alguma forma, essas preposições são responsáveis ou pelo menos influenciam nas diferenças aspectuais entre tais perífrases e, consequentemente, têm algo a ver com o aspecto expresso pelo todo da perífrase. Podemos observar o que se acabou de dizer comparando, por exemplo, os pares de perífrases especificadas em (1.369).

\footnotetext{
${ }^{9}$ IR + A + INFINITIVO não constitui uma perífrase, por isso não foi estudada no item 8.4. Na verdade, o que temos é o verbo ir indicando locomoção e "a + infinitivo" indicando a forma de locomoção (se o verbo é de movimento), ou o que se faz concomitantemente à locomoção. Os falantes no Brasil parecem preferir a construção com o gerúndio, tanto neste caso como no exemplificado nas frases (1367) e (1368)
} 
1.369. a - estar $+\mathrm{a}+$ infinitivo e estar + por + infinitivo.

$\mathrm{b}-\operatorname{vir}+\mathrm{a}+$ infinitivo e vir $+\mathrm{de}+$ infinitivo.

c - continuar $+\mathrm{a}+$ infinitivo e continuar + por + infinitivo.

$\mathrm{d}-$ acabar + de + infinitivo e acabar + por + infinitivo.

e - terminar + de + infinitivo e terminar + por + infinitivo.

A diferença entre as perífrases de $\mathbf{b}, \mathbf{d}$ e e não são propriamente aspectuais, mas para aquelas que atuam na expressão do aspecto vale o que foi dito anteriormente, pois, por exemplo, a preposição de deve ter algo a ver com o fato de "acabar ou terminar + de + infinitivo" poderem expressar o terminativo e "acabar ou terminar + por + infinitivo" não poderem.

Finalmente, observando as perífrases "estar, ficar ou continuar + por + infinitivo" e frases como (1.370), em que temos apenas "por + infinitivo", podemos dizer que a preposição por ao lado do infinitivo é a principal, senão a única responsável pela expressão do aspecto não começado no Português.

\subsection{Ainda há vários espécimes por catalogar.}

Em frases como (1.370), o "por + infinitivo" pode ser considerado como uma oração reduzida desdobrável em uma oração adjetiva com a perífrase "estar + por + infinitivo" (ver exemplo 1.371).

\subsection{Ainda há vários espécimes que estão por catalogar.}

Já dissemos que "por + infinitivo" tem sempre o valor de um atributo. A este respeito veja-se o que diz Dias (1.970, p.231-232).

\section{8 - O COMPLEMENTO E O SUJEITO DO VERBO}

Castilho (1.967, p.59) afirma que diversos contrastes aspectuais podem ser marcados pelo complemento do verbo. Segundo ele, é normal que um complemento no plural leve o verbo a expressar o aspecto iterativo. $\mathrm{O}$ autor apresenta os exemplos (1.372) a (1.374) a que acrescentamos (1.375).

1.372. "Casou-se com um grande costureiro, o mais bonito de todos eles, que desenhava todos os seus vestidos de noiva". - (A. Moniz)

1.373. "O marido é um banana [...]. A mulher deu nele uns gritos." (Lins do Rego) 
1.374. "Passou depois por mim o tropel da vida e da morte, assisti a muitos fatos históricos". - (R. Brandão)

\subsection{O rapaz pulou os obstáculos.}

Seguindo este tipo de pensamento, podemos dizer que, quando o complemento individualiza cada componente de um grupo, o verbo passa a expressar o iterativo. Exemplo:

\subsection{Bati em cada porta da rua.}

Efeito semelhante ocorre também quando o sujeito individualiza cada componente de um grupo. Confronte o exemplo (1.377) em que não há iteratividade, com o exemplo (1.378) onde haveria iteração.

1.377. Os alunos da classe bateram o sino.

1.378. Cada aluno da classe bateu o sino.

A nosso ver, esse possível efeito do complemento e do sujeito no aspecto expresso é discutível, pois, embora "saibamos" que na realidade as situações de desenhar, dar, assistir, pular e bater se repetem, a frase parece não indicar, explicitamente, a ideia de repetição que é mais logicamente deduzida do que marcada gramaticalmente.

Resta-nos dizer que os complementos do verbo podem influir no aspecto expresso, na medida em que podem fazer um verbo atélico tornar-se télico (cf. no item 3.1 os comentários em torno dos exemplos 95 e 96), pois, como vimos, o fato de o verbo ser télico ou atélico pode modificar o aspecto expresso por um dado recurso. Esta seria uma influência indireta do complemento do verbo no aspecto expresso pelo mesmo.

Temos também o efeito do objeto e do sujeito singular ou plural na estruturação e aceitabilidade de frases construídas com certas perífrases iterativas, embora não estejam influindo no aspecto (cf. exemplos em 8.2.1, 8.5.4, 8.6.1 e 8.6.2).

É comum o sujeito de uma frase com aspecto indeterminado ter sentido genérico, mas não é o sentido genérico do sujeito que leva o verbo a ter aspecto indeterminado. Ao contrário, é o aspecto indeterminado que leva o sujeito a ter tal valor. Comparem-se as frases (1.379) e (1.380).

1.379. Os gatos têm sete vidas. (imperfectivo, não acabado, indeterminado) (sujeito com sentido genérico).

1.380. Os gatos estão miando. (imperfectivo, cursivo, não acabado, durativo) (o sujeito não tem valor genérico). 


\section{0 - A relação do aspecto com a voz, o tempo e o modo verbal}

\section{1 - ReLAÇÃo ENTRE ASPECTO E VOZ}

Comrie (1976, p.84) afirma que em muitas línguas Indo-Europeias há interrelações entre aspecto e voz, e exemplifica tais inter-relações mostrando haver várias línguas em que a expressão clara de certos aspectos está restrita a uma determinada voz. No Russo, por exemplo, a expressão clara do perfeito só é possível na voz passiva.

Até onde pudemos verificar, o único aspecto que no Português apresentaria uma restrição com relação à voz é o não começado que não pode ser expresso nas vozes passiva $^{1}$ e reflexiva. Todos os demais aparecem tanto na voz ativa (como já foi sobejamente exemplificado) quanto na passiva e reflexiva, como se pode ver nos exemplos (1.381) a (1.399), em que as frases b são sempre de voz reflexiva e as demais de passiva.

1.381. a - Todos os dias pessoas são mortas sem razão, e ninguém faz nada para melhorar este trânsito. (imperfectivo, não acabado, habitual).

b - Todos os dias papai lava-se no tanque antes de entrar em casa. (imperfectivo, não acabado, habitual).

1.382. As casas naquele lugar eram feitas de madeira. (imperfectivo, não acabado, habitual).

1.383. Embora normalmente os clientes sejam avisados, nem todos respondem a nosso comunicado. (imperfectivo, não acabado, habitual).

1.384. a- A casa está sendo pintada com tinta lavável. (imperfectivo, cursivo, não acabado, durativo).

b - Maria está se penteando no meu quarto. (imperfectivo, cursivo, não acabado, durativo).

\footnotetext{
${ }^{1}$ Estaremos nos referindo sempre à passiva analítica com auxiliar ser.
} 
1.385. O menino estava sendo procurado por todos. (imperfectivo, cursivo, não acabado, durativo).

1.386. a - A terra é iluminada pelo Sol. (imperfectivo, não acabado, indeterminado).

b - Ninguém se lava com soda. (imperfectivo, não acabado, indeterminado).

1.387. A terra é dividida pelo Equador em dois hemisférios. (imperfectivo, não acabado, indeterminado).

1.388. a - A árvore foi cortada com serra. (perfectivo, acabado).

b - Ele veio chorando, porque tinha se ferido com a faca. (perfectivo, acabado).

1.389. A casa fora encerada no dia anterior. (perfectivo, acabado).

1.390. a - O ouro foi sendo roubado aos poucos. (perfectivo, durativo). b - João foi se limpando enquanto falava comigo. (perfectivo, durativo).

1.391. a - Meu filho tem sido convidado para muitas festas. (imperfectivo, não acabado, iterativo).

b - Desde que fez plástica, Maria tem-se contemplado seguidamente no espelho. (imperfectivo, não acabado, iterativo).

1.392. Se a relação das mercadorias andasse sendo alterada, seriam todos despedidos. (imperfectivo, não acabado, iterativo).

1.393. Seu relógio foi achado. (perfectivo, pontual, acabado).

1.394. a - Naquele instante, o remédio para o câncer fora descoberto. (perfectivo, pontual, acabado). b - Maria feriu-se com a faca. (perfectivo, pontual, acabado).

1.395. A construção está sendo iniciada. (imperfectivo, começado, inceptivo).

1.396. a - Os tacos estão começando a ser lixados para passar sinteco. (imperfectivo, começado, inceptivo).

b - Sérgio está começando a lavar-se. (imperfectivo, começado, inceptivo).

1.397. A colheita está sendo terminada. (imperfectivo, não acabado, terminativo).

1.398. a - Os suspeitos estão terminando de ser interrogados. Só então poderemos dizer algo. (imperfectivo, não acabado, terminativo). b - Celina está terminando de pentear-se. (imperfectivo, não acabado, terminativo). 
É interessante notar que, na passiva, quando o auxiliar ser está no presente e pretérito imperfeito do indicativo e do subjuntivo, há uma tendência para o habitual, embora possamos ter o cursivo e o durativo. Estes aparecem se a forma verbal é usada numa descrição simultânea (cf. exemplos 1.254 e 1.399).

1.399. A árvore é balançada fortemente pelo vento. (imperfectivo, cursivo, não acabado, durativo).

Para indicação do cursivo e durativo nestes tempos, o falante prefere utilizar a perífrase "estar + gerúndio".

O aspecto pontual, cuja expressão já é pouco frequente na língua, parece ser expresso, nas vozes passiva e reflexiva apenas em frases como (1.393) e (1.394 a, b) com os pretéritos perfeito e mais-que-perfeito do indicativo e verbo indicador de situação estritamente pontual.

Os aspectos inceptivo e terminativo podem aparecer em frases como (1.395) a (1.398); mas frases de passiva como (1.396 a) e (1.398 a), apesar de possíveis, não são muito usadas e podem soar como um pouco estranhas.

$\mathrm{O}$ aspecto indeterminado é possível na voz reflexiva, mas muito pouco frequente.

\section{2 - RELAÇÃO ENTRE ASPECTO E TEMPO}

No capítulo 7, estudamos a expressão do aspecto pelos tempos flexionais. Aqui comentaremos a relação entre o aspecto e o tempo (= época).

Ao estudar a expressão do aspecto pelas flexões verbais observamos que, quando estas tinham valor de presente ou passado, havia atualização de aspecto, mas não quando tinham valor de futuro.

No item 7.2, vimos que o presente do indicativo não indica aspecto quando usado com valor de futuro (caso a, exemplos 332 a 335). Também nos casos d (exemplos 341 a 343) e e (exemplos 344 a 346) de não atualização do aspecto com o presente do indicativo, podemos atribuí-la ao valor de futuro que ali aparece. Podemos ver no item 7.3 que, nos dois casos em que o pretérito imperfeito do indicativo não expressa aspecto, o valor temporal é futuro (exemplos 405 a 408). No item 7.5, vimos que o futuro do presente e o futuro do pretérito (tempos flexionais que normalmente marcam o futuro) em si não expressam aspecto, só havendo atualização desta categoria pela atuação de outros recursos. Também no imperativo (cf. item 7.6) o valor temporal de futuro, ao lado da modalidade, bloqueia a atualização 
do aspecto. Com os tempos flexionais do subjuntivo, a categoria aspectual só se atualiza, se eles tiverem valor temporal de presente ou passado; pois com valor futuro estas flexões verbais não expressam qualquer noção aspectual (cf. no item 7.7 a exemplificação e os comentários feitos).

Apesar da restrição do futuro à atualização do aspecto, encontramos numerosos exemplos em que esta categoria se acha atualizada, apesar do valor temporal de futuro. Normalmente isto se dá pela atuação de certos recursos de expressão do aspecto, tais como as perífrases e os adjuntos adverbiais. Exemplos disto podem ser observados nas frases de números (433) a (437), (440), (441), (444 a 448), (591), (689), (693) e (739). Isto vem mostrar que o aspecto não é de todo incompatível com o futuro no Português. Adrados (1.954, p.261) advoga posição semelhante com relação ao grego, ao se opor à colocação de Ruiperez de que o aspecto em si é incompatível com o futuro.

Uma observação interessante a ser feita é que, quando temos aspecto com o tempo futuro, a situação apresentada como futura normalmente é presente ou passada em relação a uma outra situação (expressa em outra oração ou especificada no contexto), ou a um dado momento expresso por adjunto adverbial de tempo. Geralmente a situação futura é apresentada como presente a outra, se tivermos os aspectos imperfectivo e cursivo ou apenas imperfectivo (cf. exemplos 434, 457, $458,739,771,819$ e 1.400 a 1.408 ) e como passada, se tivermos aspecto perfectivo (cf. exemplos 443, 591, 690, 693 e 1.409 a 1.412).

1.400. Quando ele estiver chegando, vocês poderão sair. (imperfectivo, cursivo, não acabado).

1.401. Quando ele chegar, eu estarei terminando de datilografar o relatório. (imperfectivo, terminativo, não acabado).

1.402. Às quinze horas eu vou estar estudando na casa da Raquel. (imperfectivo, cursivo, não acabado, durativo).

1.403. Estarei doente quando você vier. (imperfectivo, cursivo, não acabado, durativo).

1.404. Quando você chegar, o milho estará cozinhando. (imperfectivo, cursivo, não acabado, durativo).

1.405. Se o Paulo estiver dormindo quando você passar na casa dele, acorde-o. (imperfectivo, cursivo, não acabado, durativo).

1.406. Às seis horas terei a lição estudada.

a - S.R.: ter a lição estudada - imperfectivo, cursivo, não acabado, durativo.

b- S.N.: estudar - acabado. 
1.407. Terei o dinheiro, quando você vier. (imperfectivo, cursivo, durativo, não acabado).

1.408. Quando você vier me visitar, já serei presidente da firma. (imperfectivo, não acabado, indeterminado).

$\mathrm{O}$ aspecto no futuro com verbos simples só parece ser possível com verbos estáticos (exemplos 1.403, 1.407 e 1.408), ou com o auxílio de adjuntos adverbiais (exemplos 444 a 448).

1.409. Quando ele tiver chegado, vocês poderão sair. (perfectivo, acabado).

1.410. Eu terei terminado o trabalho, quando você voltar. (perfectivo, acabado).

1.411. Quando voltarmos, Edna já vai ter preparado o almoço. (perfectivo, acabado).

1.412. Quando o aviso chegar, ele já terá escrito a carta. (perfectivo, acabado).

Observe-se também que o futuro do pretérito, quando expressa aspecto, perde seu valor de futuro, tendo apenas a função de introduzir a noção modal de possibilidade (hipótese) em uma situação presente hipotética, se o aspecto for o imperfectivo (exemplos 439, 740, 756, 787, 820 e 1.413 a 1.416); ou em uma situação passada hipotética, se o aspecto for o perfectivo (exemplos 438, 690, 1.417 e 1.418). Este fato também ocorre com o futuro do subjuntivo, normalmente quando temos o verbo em oração introduzida por SE (cf. exemplos 743, 759, 790, 823 e 1.419 para o presente e o imperfectivo, e os exemplos 1.420 e 1.421 para o passado e o perfectivo).

1.413. Eu estaria passeando, se não tivesse que fazer este trabalho. (imperfectivo, cursivo, não acabado, durativo).

1.414. Eu teria a mesa posta, se as crianças não tivessem me atrapalhado tanto. (S.R.: ter a mesa posta - imperfectivo, cursivo, não acabado, durativo).

1.415. Eu possuiria muitos bens, se não tivesse sido tão imprevidente. (imperfectivo, cursivo, não acabado, durativo).

1.416. O vaso estaria sobre a mesa, se você não o tivesse tirado. (imperfectivo, cursivo, não acabado, durativo).

1.417. Eu teria terminado o trabalho, se vocês não tivessem me atrapalhado. (perfectivo, acabado). 
1.418. Aquele homem teria roubado minha carteira, se essa senhora não me avisasse. (perfectivo, acabado).

1.419. Se você estiver respirando bem, acho desnecessário fazer a operação. (imperfectivo, cursivo, não acabado, durativo).

1.420. Se meu filho tiver quebrado o vidro de sua janela mando colocar outro. (perfectivo, acabado).

1.421. Se Mariana tiver raspado a tinta velha, num instante faremos o trabalho. (perfectivo, acabado).

Vimos que o futuro do presente também perde o seu valor de futuro e passa a ter valor temporal de presente ou passado, se temos atualização dos aspectos imperfectivo ou perfectivo, respectivamente, sem que a situação indicada pelo futuro do presente seja presente ou passada em relação a outra situação ou momento futuro. Isto ocorre em frases como (929) a (931) e (1.422) a (1.426), normalmente de valor hipotético e sempre interrogativas.

1.422. Seu irmão não andará comendo escondido de vocês? (presente) (imperfectivo, não acabado, iterativo).

1.423. O que este homem estará procurando? (presente) (imperfectivo, cursivo, não acabado, durativo).

1.424. Seu tio não viverá se aproveitando da boa fé de vocês? (presente) (imperfectivo, não acabado, habitual).

1.425. Você não terá esquecido sua bolsa na casa de alguma amiga? (passado) (perfectivo, acabado).

1.426. O Flávio terá trazido o que lhe encomendei? (passado) (perfectivo, acabado).

Observe-se ainda que:

a. o presente do indicativo sempre marca aspecto imperfectivo, exceto quando marca o pontual e, em consequência, o perfectivo, nas condições especificadas no item 4.2.8;

b. o pretérito imperfeito do indicativo, único tempo flexional marcador de passado que expressa o imperfectivo, é na realidade um presente no passado;

c. os pretéritos perfeito e mais-que-perfeito do indicativo são marcadores de passado e sempre expressam perfectivo;

d. o presente do subjuntivo, quando tem sentido presente, sempre marca imperfectivo, exceto em frases como (1.427) - que raramente ocorrem - e se comporta aspectualmente da mesma forma que o presente do indicativo; 
1.427. Embora Pedro chegue na sala e descubra angustiado que sua mãe está morta, não solta um ai e não chora. (perfectivo, acabado).

e. o pretérito imperfeito do subjuntivo, quando tem sentido presente, sempre expressa o imperfectivo e, quando tem sentido passado, se comporta, em relação ao aspecto, de maneira semelhante ao pretérito imperfeito do indicativo, sendo também um presente no passado;

f. o futuro do subjuntivo, quando tem valor de presente, expressa o imperfectivo.

Diante de tudo o que já foi dito, podemos estabelecer as seguintes conclusões no que diz respeito à relação entre o tempo e o aspecto:

1. quanto temos o presente ou o passado, o aspecto se atualiza normalmente, sem qualquer restrição e pela ação de qualquer meio de expressão;

2. o futuro normalmente restringe a atualização dos aspectos e nenhum deles se atualiza neste tempo apenas pela ação da flexão temporal. Há sempre a ação de um dos seguintes meios de expressão: perífrases, semantema do verbo, adjuntos adverbiais e a repetição do verbo;

3. os aspectos imperfectivo e perfectivo só se atualizam no futuro, se a situação futura for respectivamente presente ou passada em relação a outra situação futura ou em relação a um momento futuro dado;

4. o imperfectivo aparece sempre ligado ao tempo presente que pode ser absoluto ou relativo ${ }^{2}$, pois, se a situação for passada ou futura, teremos sempre um presente relativo;

5. o perfectivo aparece sempre ligado ao tempo passado, exceto quando junto com o pontual no presente. O passado pode ser absoluto ou relativo, pois, se a situação for futura, teremos sempre um passado relativo;

6. o cursivo também parece se atualizar apenas quando temos o presente, seja este absoluto ou relativo; entretanto, isto pode se dever ao fato de que este aspecto só aparece ao lado do imperfectivo.

Vimos que o futuro restringe a atualização do aspecto, embora não a impeça de maneira total. Qual seria a razão desta ação restritiva do futuro?

\footnotetext{
${ }^{2}$ Estamos chamando de tempo absoluto aquele estabelecido em relação ao momento da fala, e de relativo o estabelecido em relação a um tempo absoluto ou em relação ao momento de ocorrência de outra situação da seguinte maneira: sejam as situações A e B. Se A é simultânea a B então A é presente a B. Se A é anterior a B então A é passada em relação a B.
} 
Castilho (1967, p.109) afirma que as muitas funções modais do futuro restringem a sua atuação na expressão do aspecto, e que este só aparece quando as funções modais se neutralizam.

O futuro realmente tem uso modal, podendo introduzir a modalidade de intenção (cf. item 10.3). Poder-se-ia pensar que a hipótese (probabilidade) aparece com o futuro, quando aparece com o futuro do presente (tempo flexional) em frases como (929) a (931), (1422) e (1424) a (1426). Contudo vimos que, neste caso, não temos o futuro, mas sim o presente ou o passado. A hipótese aparece no futuro quando temos o futuro do pretérito.

Luft (1976, p.131) coloca que, na verdade, não haveria um tempo flexional futuro, mas sim locuções de "infinitivo + haver" do tipo:

$$
\begin{aligned}
& \text { cantar }+ \text { hei } \\
& \text { cantar }+ \text { hia }
\end{aligned}
$$

com aglutinação na pronúncia representada na escrita: cantarei, cantaria. $\mathrm{O}$ futuro teria uma semântica de decisão, projeto, hipótese (valores modais), derivada de "haver" e a ideia de futuro seria uma implicação secundária de que planos, decisões etc. se projetam no futuro.

A colocação de Luft tem fundamento na história da língua, já que os nossos chamados futuro do presente e futuro do pretérito tiveram origem nas perífrases de "infinitivo + haver"; contudo nosso pensamento é que, no estágio atual da língua, pode-se dizer que há um tempo flexional futuro. Nosso intuito, ao citar tais colocações, foi mostrar a provável origem do valor modal do futuro expresso por aqueles tempos flexionais, já que "haver" é um auxiliar modal (cf. item 10.3 e BECHARA, 1.977, p.112).

Comrie (1976), que trata do assunto de maneira geral sem se referir a nenhuma língua em especial, falando sobre tempo, também registra que "o chamado tempo futuro de muitas línguas tem valor modal, bem como o de tempo". Todavia este autor não atribui a tal valor o fato de o futuro restringir o aspecto, pois, à página 73, afirma que a razão da ausência de uma distinção aspectual bem marcada neste tempo pode ser o fato de o futuro, em muitas línguas, ser um tempo pobremente diferenciado, como um tempo distinto do presente. Esta não nos parece ser a causa da restrição do aspecto pelo futuro no Português.

Adrados (1.954, p.266, nota 12) registra a afirmação de Chantraine de que, em uma ação futura, não interessa grandemente destacar o aspecto. Esta seria uma razão pragmática para a restrição do aspecto pelo futuro. 
Pode-se facilmente observar, nas frases em que o aspecto se atualiza com o tempo futuro, que, frequentemente, o valor modal do futuro não se neutraliza quando o aspecto está atualizado neste tempo. Assim sendo, não se pode afirmar que seja só pelo valor modal que o futuro restringe a atualização do aspecto, pois se assim fosse, quando aquele estivesse presente, este não se atualizaria. Pode-se, entretanto, aventar a hipótese de que certos recursos de expressão do aspecto são capazes de contornar ou anular o efeito da modalidade sobre o aspecto.

Dissemos, no item 7.5, que o tempo futuro atribui à situação uma realização virtual, até certo ponto abstrata. Isto anularia ou enfraqueceria o aspecto que fosse atualizado, dificultando sua percepção, o que torna desinteressante atualizar a categoria. $\mathrm{O}$ falante só se empenharia em tal atualização, quando ela fosse consideravelmente necessária, para justificar a utilização de recursos fornecidos pela língua para superar o efeito da realização virtual atribuída à situação.

Sobre o efeito do valor modal ver-se o que dizemos no item 10.3.

A não atualização da categoria de tempo parece implicar também na não atualização do aspecto. Isto porque a não atualização do tempo, normalmente, só ocorre quando há a intenção de se referir apenas à situação em si, sem qualquer referência ao TEMPO envolvido na sua ocorrência.

\section{3 - RELAÇÃO ENTRE ASPECTO E MODO}

Em várias passagens, aludimos ao fato de que a modalidade ${ }^{3}$ restringe a atualização do aspecto e mesmo nos detivemos neste particular, ao falarmos da expressão do aspecto pelas flexões verbais do subjuntivo.

Castilho (1.967, p.108) anota que, embora não se possa falar de incompatibilidade, observa-se que as noções aspectuais nem sempre ocorrem simultaneamente às noções de volição, possibilidade e intenção. Estas são, sem dúvida, noções modais.

Por modalidade entende-se a designação, na frase, da atitude do falante com relação ao seu próprio enunciado, a explicitação da atitude psíquica do falante em face da situação que exprime.

São as seguintes as noções modais:

\footnotetext{
${ }^{3}$ Preferimos aqui utilizar o termo modalidade no lugar do termo modo, visto que este está comprometido com os "modos gramaticais" (indicativo, subjuntivo e imperativo), mas os dois termos são usados frequentemente como sinônimos. Os "modos gramaticais" são apenas um dos meios de marcar a modalidade que pode também, por exemplo, ser marcada por advérbios (talvez, provavelmente, que marcam dúvida), ou uma oração principal com verbos do tipo de crer, proibir, temer, ordenar, e até mesmo pela entonação como afirma Bally (1942, p.10). (BALLY, C. Syntaxe de la modalité explicite. Cahiers Ferdinand de Saussure, Geneve, v. 2, p.3-13, 1942.).
} 


\section{1 - Certeza}

Normalmente é expressa ${ }^{4}$ pelos tempos do indicativo (cf. como exemplos a quase totalidade das frases com o verbo no indicativo apresentadas neste trabalho e (1.428) abaixo).

1.428. Hélvio deu-me um quadro de presente.

\section{2 - Prescrição}

A prescrição pode ser:

a. ordenativa positiva ou negativa. A prescrição ordenativa negativa é a proibição. São expressas pelo imperativo (exemplos 1.429 a 1.431).

\subsection{Lê este livro!}

1.430. Leia este livro!

1.431. Não saia daqui!

b. aconselhativa. Expressa pelo auxiliar dever na segunda ou terceira pessoas na perífrase DEVER + INFINITIVO, ou pelo imperativo com entonação adequada. Exemplos:

1.432. Deves ler este livro.

1.433. Você deve lhe pedir desculpas.

1.434. Não beba que é ruim para a saúde.

\section{3) Obrigação}

É expressa pelo auxiliar ter na perífrase TER + DE + INFINITIVO. Exemplos:

1.435. Tenho de ler este livro.

1.436. Tens de ajudar teus irmãos.

1.437. Sérgio tem de prestar contas ao chefe toda tarde.

\section{4) Necessidade}

É expressa pelo auxiliar dever na primeira pessoa, pelo auxiliar precisar em qualquer pessoa, nas perífrases PRECISAR ou DEVER + INFINITIVO (exemplos

\footnotetext{
${ }^{4}$ Não fizemos um levantamento exaustivo das formas de expressão das modalidades aqui expostas. Assim sendo, as formas de expressão registradas são as mais comuns e frequentes na língua. Além das que citamos no item 10.3, vejam-se também as apresentadas no item 7.7 , bem como toda a exemplificação apresentada neste último.
} 
1.438 a 1.440), ou por construções do tipo "é preciso ou é necessário + oração com verbo no subjuntivo ou infinitivo" (exemplos 1.441 a 1.443).

1.438. Devo ler este livro logo.

1.439. Preciso encontrar-me com seu irmão.

1.440. Você precisa se alimentar melhor.

1.441. É preciso estar alerta.

1.442. É preciso que você venha.

1.443. É necessário que você preste mais atenção.

\section{5) Volição}

Expressa por verbos como querer e desejar, usados principalmente como auxiliares, em perífrases com o verbo principal no infinitivo (exemplos $1.444 \mathrm{e}$ 1.445) e também pelo subjuntivo (exemplo 1.446).

1.444. Quero ler este livro.

1.445. Deseja comprar algo, meu rapaz?

1.446. Deus os proteja nesta difícil tarefa!

6) Intenção

É expressa pelo auxiliar haver na perífrase HAVER + DE + INFINITIVO (exemplo 1.447), ou pelo futuro do presente (exemplos 1.448 e 1.449).

1.447. Hei de passar no concurso.

1.448. Lerei este livro amanhã.

1.449. Comprarei um carro, para poder trabalhar mais facilmente.

É frequente a intenção vir ao lado da volição como em (1.447).

\section{7) Possibilidade}

É expressa pelo auxiliar poder na perífrase PODER + INFINITIVO (exemplos 1.450 e 1.451), ou por expressões do tipo "é possível + oração reduzida de infinitivo" (exemplos 1.452 e 1.453).

1.450. Posso ler este livro quando quiser.

1.451. Ele pode fazer isso melhor do que você.

1.452. É possível encontrar coisas muito boas nesta feira.

1.453. É possível ir de carro à aldeia? 
Normalmente, possibilidade + interrogação $=$ permissão. Exemplos:

1.454. Posso ler este livro?

1.455. Posso usar sua máquina de escrever?

A permissão e o consentimento, que são subtipos da possibilidade, também podem ser expressos por DEIXAR + INFINITIVO. Exemplo:

1.456. Papai deixou-nos ir ao cinema. (deu a possibilidade).

É importante observar que temos dois tipos de possibilidade: a correspondente a "ser exequível" ou "ter aptidão", que chamaremos de possibilidade - 1, e a correspondente a uma "hipótese", que chamaremos de possibilidade - 2. Esta aparece em exemplos tais como (438), (439), (468) a (471), (545), (565) e (566).

\section{8) Probabilidade}

É expressa pelo auxiliar dever na perífrase DEVER + INFINITIVO (exemplos 1.457 a 1.459$)^{5}$, ou por expressões de dúvida + subjuntivo (exemplos 1.460 a 1.463 ).

1.457. Devo estar aí lá pelas três horas.

1.458. Devo examinar seu caso ainda hoje.

1.459. Ele deve gostar disso.

1.460. Talvez ele venha amanhã.

1.461. É possível que o diretor ainda te atenda.

1.462. É provável que a fera não ataque ninguém.

Também a probabilidade pode ser de dois tipos: a correspondente a "ser exequível" (probabilidade -1) e a correspondente a uma "hipótese" (probabilidade -2). Esta aparece em exemplos tais como (539), (540), (546) e (1463) abaixo.

1.463. É provável que Célio esteja em casa agora.

\footnotetext{
${ }^{5}$ As frases com o auxiliar dever têm sempre duas interpretações: uma de necessidade, outra de probabilidade. Portanto os exemplos (1.438), (1.457) e (1.458) podem ter tanto a modalidade de necessidade quanto a de probabilidade. Somente o contexto nos permite saber se temos uma ou outra. É bom observar que uma frase como "Devem ser quatro horas." só terá uma interpretação de necessidade num contexto muito especial
} 
A fronteira entre probabilidade e possibilidade não é muito nítida, assim, frequentemente, se torna difícil decidir entre uma e outra.

Como se pode observar nos exemplos (1.429) a (1.462) e também nos exemplos (459) a (467) e (472) a (536), além de outros, quando certas modalidades estão presentes na frase, o aspecto normalmente não se atualiza.

Podemos observar que a modalidade de certeza não restringe a atualização do aspecto. A possibilidade e a probabilidade só o fazem quando se atribui à situação uma realização futura, o que normalmente ocorre com a possibilidade - 1 e a probabilidade -1 , donde se conclui que a possibilidade -2 e a probabilidade -2 também não restringem a atualização do aspecto. Já a prescrição (ordenativa ou aconselhativa), a obrigação, a necessidade, a volição e a intenção quase sempre bloqueiam a atualização do aspecto e, dificilmente, aparecem com uma situação cuja realização não seja futura.

Como já dissemos no item 7.7, as modalidades que mais restringem a atualização do aspecto são, portanto, aquelas que pressupõem uma realização futura para a situação a que se aplicam. Por outro lado vimos, no item 7.5 e no item 10.2, que o futuro que também restringe a atualização do aspecto, normalmente tem valor e função modal que podem ser a causa de sua atuação restritiva. Parece que temos aqui uma questão do tipo da precedência do ovo e da galinha: certas modalidades restringem a atualização do aspeto por atribuírem à situação uma realização futura ou é o contrário? Além destas duas hipóteses, temos uma terceira: a de que seria a ação conjunta de modalidade e futuro que restringiria a atualização do aspecto. A resolução desta questão é algo que deixamos como sugestão para futuros trabalhos. Todavia fica claro que o futuro e algumas modalidades restringem a atualização do aspecto.

Uma outra razão que pode explicar a ação restritiva da modalidade é o fato de que há na noção modal uma imperfectividade inerente. Daí não se poder atualizar o aspecto para o verbo que expressa a situação a que a modalidade se aplica (cf. para exemplo 1.464 e 1.465$)$.

1.464. Eu posso escrever uma carta.

posso $\rightarrow$ tenho a possibilidade (imperfectivo, não acabado, cursivo, durativo).

1.465. Consertarei o ferro de passar hoje à tarde.

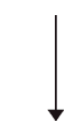

tenho a intenção de consertar (imperfectivo, cursivo, não acabado, durativo). 
A restrição do aspecto pela modalidade não é total, pois é comum encontrarmos, na língua, exemplos em que o aspecto se atualiza apesar da modalidade estar presente (normalmente possibilidade -2 ou probabilidade -2 , mas também outras). Quando isto ocorre, normalmente o aspecto é marcado por perífrases. Estas parecem ser o único recurso de expressão do aspecto capaz de anular o efeito da modalidade. Exemplos:

1.466. Você pode estar morrendo e não saber. (imperfectivo, cursivo, não acabado, durativo).

1.467. Ele parece ter estudado a lição. (perfectivo, acabado).

1.468. Vá separando o material para mim! (durativo).

1.469. Seu irmão deve andar matando aula. (iterativo).

Observe-se que, às vezes, o valor de futuro desaparece como em (1.466), (1.467) e (1.469), mas permanece em (1.468). Vejam-se também os exemplos (457) e (458), em que temos aspecto com a modalidade de prescrição ordenativa. Nestes dois exemplos a noção de futuro permanece, mas a situação é presente relativamente a outra situação futura especificada na oração adverbial temporal. 


\section{Conclusão}

Fechando este estudo, apresentamos em linhas gerais os resultados a que chegamos. Estamos conscientes de que, como todo trabalho dentro da ciência linguística, também este não é completo nem definitivo: há muitos pontos que merecem um estudo particular e mais pormenorizado, alguns dos quais relembramos abaixo; e, além disso, novas abordagens sempre são possíveis.

Conceituamos o aspecto como uma categoria verbal de TEMPO, não dêitica, por meio da qual se marca a duração da situação e/ou suas fases, sendo que estas podem ser consideradas sob diferentes pontos de vista, a saber: o do desenvolvimento, o do completamento e o da realização da situação (cf. item 2.1).

Estabelecemos o elenco das noções aspectuais, que se acha resumido no quadro I no item 2.2.

Verificamos que algumas noções semânticas têm sua ocorrência condicionada ao aparecimento de certos aspectos ou noções aspectuais, mas não se incluem no grupo destas últimas, como normalmente afirmam tratados sobre o aspecto (cf. item 2.3). Abaixo apresentamos tais noções e o aspecto a que se ligam:

\begin{tabular}{l|l}
\hline \multicolumn{1}{c|}{ NOÇÃO SEMÂNTICA } & \multicolumn{1}{c}{ ASPECTO } \\
\hline a) Habitualidade & Habitual (iteração criada pela duração \\
\hline & descontínua ilimitada) \\
\hline b) Incoação & Não depende do aspecto, mas sempre \\
\hline & $\begin{array}{l}\text { está ligada ao início de um estado - } \\
\text { Incepção }\end{array}$ \\
\hline c) Progressividade & Durativo \\
\hline d) Permansividade & Acabado \\
\hline e) Resultatividade - 2 & Perfectivo \\
\hline f) Cessamento & Acabado \\
\hline g) Experienciamento & Perfectivo \\
\hline
\end{tabular}

Os tipos de situações que interferem com o aspecto expresso são: a) situações télicas e atélicas; b) situações dinâmicas (processos e eventos) e estáticas (particularmente os estados) (cf. capítulo 3); c) situações que não admitem descontinuidade no seu tempo de existência. 
Estabelecemos a distinção entre situação narrada e referencial (cf. item 3.3). Essa distinção se mostrou particularmente útil na análise aspectual, resolvendo problemas de análise e interpretação que levaram estudiosos do assunto à proposição de quadros aspectuais com problemas de coerência interna e com os exemplos analisados.

Demonstramos que um quadro de aspectos simples é preferível a um quadro misto de aspectos simples e compostos (cf. item 4.1), e estabelecemos o quadro aspectual do Português que pode ser visto no quadro III, item 4.2, em que cada aspecto é caracterizado por uma noção aspectual.

Estabelecemos também as relações possíveis entre os diferentes aspectos, que se acham resumidas no quadro IV, no capítulo 5.

Levantamos a possibilidade de existência de aspecto nos nomes (cf. capítulo 6), mas não nos detivemos neste particular. Esta questão é objeto de estudo para futuros trabalhos sobre o aspecto.

Quanto à expressão do aspecto, vimos serem os seguintes os elementos que nela atuam: a flexão verbal, as perífrases, o semantema do verbo, os adjuntos adverbiais, o tipo oracional, a repetição do verbo, a ênfase entonacional, as preposições e o complemento do verbo. No Português não há afixos que expressam aspecto (cf. item 9.3) e vimos ser discutível uma possível influência do sujeito no aspecto expresso (cf. item 9.8). Vejamos alguns fatos sobre cada um dos recursos de expressão do aspecto

Sobre a flexão verbal (cf. capítulo 7) pudemos observar o seguinte:

1. o presente do indicativo (cf. item 7.2) em si marca os aspectos imperfectivo, o cursivo (este em descrições simultâneas e na linguagem mais formal, sendo mais claro com verbos de situação estática), o habitual, o não acabado e o indeterminado. Outros aspectos só são expressos com o auxílio de outros recursos: o pontual e o perfectivo (em descrições simultâneas e com verbos de situação estritamente pontuais), o acabado (com o auxílio de adjuntos adverbiais) e o durativo (com o auxílio do semantema);

2. o pretérito imperfeito do indicativo (cf. item 7.3) em si marca o imperfectivo, o cursivo, o durativo (quando a situação expressa é presentificada a uma situação ou momento passado), o habitual e o indeterminado. $\mathrm{O}$ pretérito imperfeito de verbos estáticos e atélicos, quando enfatizado entonacionalmente, marca o aspecto acabado;

3. o pretérito perfeito do indicativo (cf. item 7.3) em si marca apenas o perfectivo. Com o auxílio de outros recursos pode marcar os seguintes aspectos: o pontual (com verbos de situação estritamente pontuais); o durativo (com verbos de estado, pela influência de adjuntos adverbiais 
e orações adverbiais temporais e pela repetição do verbo); o iterativo e o habitual (pela influência de adjuntos adverbiais) e o acabado (com verbos estáticos e télicos);

4. o pretérito mais-que-perfeito do indicativo (cf. item 7.4) em si marca os aspectos perfectivo e acabado. Com o auxílio de outros recursos ele pode expressar os aspectos pontual, durativo, iterativo e habitual nas mesmas condições especificadas acima para o pretérito perfeito;

5. os futuros do presente e do pretérito (cf. item 7.5) e o imperativo (cf. item 7.6) em si não marcam qualquer aspecto. Só teremos aspecto com estas flexões verbais pela ação de recursos como as perífrases e os adjuntos adverbiais;

6. os tempos flexionais do subjuntivo (cf. item 7.7) só indicam aspecto, quando têm valor temporal de presente ou de passado e com as modalidades de certeza, possibilidade - 2 e probabilidade - 2 . Normalmente eles expressam os aspectos imperfectivo, não acabado e cursivo. $\mathrm{O}$ futuro do subjuntivo normalmente expressa estes aspectos com verbos de situação estática, portanto com influência do semantema. O durativo só é expresso pelos tempos do subjuntivo, com o auxílio do semantema. O presente e o pretérito imperfeito do subjuntivo podem expressar ainda o habitual (com ou sem a influência de elementos adverbiais - adjuntos ou orações), e o indeterminado. Outros aspectos só aparecem pela ação de recursos diferentes das flexões verbais do subjuntivo;

7. quanto às formas nominais temos o seguinte quadro:

a) o infinitivo (cf. item 7.8.1) em si não marca qualquer aspecto. Contudo com o infinitivo de um verbo de situação estática (principalmente de estado), temos os aspectos imperfectivo, não acabado, cursivo e durativo; b) o gerúndio (cf. item 7.8.2) em si também não marca qualquer aspecto, embora apresente uma tendência para expressão do não acabado, do cursivo e do durativo. $\mathrm{O}$ aspecto que se pode considerar atualizado no gerúndio depende do tipo de oração desenvolvida a que a reduzida de gerúndio corresponde (portanto da interpretação que se lhe dá), e do tempo flexional do verbo da oração principal. Em alguns casos, o fato de termos verbo de situação dinâmica ou de situação estática também modifica o aspecto que estaria expresso. As diferentes interpretações que se pode dar às reduzidas de gerúndio nos impedem de fazer uma análise aspectual segura. Os únicos casos em que não há dúvida é com as orações reduzidas de gerúndio de verbos de situação estática 
(normalmente causais e concessivas), e com as reduzidas de gerúndio adjetivas em que temos, indubitavelmente, os aspectos imperfectivo, não acabado, cursivo e durativo;

c) o particípio (cf. item 7.8.3) marca o aspecto acabado, independente do tempo em que está o verbo da oração principal. Se ele indica um estado resultante do término de uma ação, o acabado é da S.N. representada pela ação. A S.R., que é o estado, tem aspectos imperfectivo, não acabado, cursivo e durativo.

É preciso observar ainda que a relação de tempos flexionais, nas orações principais e subordinadas, pode afetar o aspecto atualizado. Veja os exemplos (585) e (586) e o caso do pretérito imperfeito do indicativo que terá aspectos cursivo e durativo, se tivermos pretérito imperfeito do indicativo (na principal) + pretérito perfeito do indicativo (na adverbial temporal) e habitual, se tivermos pretérito imperfeito do indicativo nas duas orações.

Para as perífrases (cf. capítulo 8), temos os seguintes quadros em que_apresentamos as que expressam cada aspecto e as condições em que o fazem:

\section{1) Acabado}

\begin{tabular}{l|l}
\hline $\begin{array}{l}\text { Ter }+ \text { particípio (invariável) } \\
\text { Haver }+ \text { particípio }\end{array}$ & $\begin{array}{l}\text { Com todas as flexões verbais em que são } \\
\text { possíveis, exceto o presente do indicativo, } \\
\text { e com qualquer tipo de verbo principal. }\end{array}$ \\
\hline Ter + objeto + particípio (variável) & $\begin{array}{l}\text { Para a S.N. com qualquer flexão verbal, e } \\
\text { para a S.R. nos pretéritos perfeito e mais- } \\
\text { que-perfeito do indicativo. }\end{array}$ \\
\hline $\begin{array}{l}\text { Estar }+ \text { gerúndio } \\
\text { Estar }+ \text { particípio }\end{array}$ & $\begin{array}{l}\text { Para S. R. nos pretéritos perfeito e mais- } \\
\text { que-perfeito do indicativo. }\end{array}$ \\
\hline Estar + particípio & Para a S.N. com qualquer flexão verbal. \\
\hline Vir + de + infinitivo & $\begin{array}{l}\text { Com qualquer flexão verbal em que é } \\
\text { possível. }\end{array}$ \\
\hline $\begin{array}{l}\text { Cessar/ Deixar / Parar / Acabar / Terminar } \\
+ \text { de }+ \text { infinitivo }\end{array}$ & $\begin{array}{l}\text { Para a S.N. nos pretéritos perfeito e mais- } \\
\text { que perfeito do indicativo. }\end{array}$ \\
\hline $\begin{array}{l}\text { Acabar }+ \text { de }+ \text { infinitivo } \\
\text { Ner }+ \text { particípio variável de verbo } \\
\text { intransitivo }\end{array}$ & $\begin{array}{l}\text { po indicativo e do subjuntivo e nos pretéritos } \\
\text { perfeito e mais-que-perfeito do indicativo, } \\
\text { para as situações indicadas pelo infinitivo. }\end{array}$ \\
\hline
\end{tabular}




\section{2) Não começado}

\begin{tabular}{l|l}
\hline $\begin{array}{l}\text { Estar }+ \text { para } / \text { em } / \text { por + infinitivo } \\
\text { Continuar + por + infinitivo }\end{array}$ & $\begin{array}{l}\text { Para a S.N. expressa pelo infinitivo, com } \\
\text { qualquer flexão verbal. }\end{array}$ \\
\hline & $\begin{array}{l}\text { Para a S.N. com qualquer flexão verbal. } \\
\text { Ficar + por + infinitivo }\end{array}$ \\
& $\begin{array}{l}\text { Ficar = "conservar-se em determinada } \\
\text { situação". }\end{array}$ \\
\hline
\end{tabular}

3) Começado ou não acabado

\begin{tabular}{|c|c|}
\hline Ter + particípio invariável & No presente do indicativo. \\
\hline $\begin{array}{l}\text { Ter }+ \text { objeto }+ \text { particípio (variável) } \\
\text { Estar }+ \text { gerúndio } \\
\text { Estar }+ \text { particípio } \\
\text { Estar }+\mathrm{a} / \text { para / por / em }+ \text { infinitivo }\end{array}$ & $\begin{array}{l}\text { Para a S.R., com qualquer flexão verbal, } \\
\text { exceto nos pretéritos perfeito e mais que } \\
\text { perfeito do indicativo. }\end{array}$ \\
\hline $\begin{array}{l}\text { Vir }+ \text { gerúndio } \\
\text { Andar }+ \text { gerúndio } / \mathrm{a}+\text { infinitivo } \\
\text { Viver }+ \text { gerúndio } / \mathrm{a}+\text { infinitivo } / \text { particí- } \\
\text { pio }\end{array}$ & $\begin{array}{l}\text { Com qualquer flexão verbal, exceto os } \\
\text { pretéritos perfeito e mais-que-perfeito do } \\
\text { indicativo. } \\
\text { Com qualquer flexão verbal em que são } \\
\text { possíveis. }\end{array}$ \\
\hline $\begin{array}{l}\text { Permanecer }+ \text { gerúndio } / \mathrm{a}+\text { infinitivo } / \\
\text { particípio }\end{array}$ & $\begin{array}{l}\text { Para a situação expressa pelo verbo } \\
\text { principal, quer seja S.N., quer seja S.R., } \\
\text { com qualquer flexão verbal em que são } \\
\text { possíveis. Permanecer = "continuar". }\end{array}$ \\
\hline $\begin{array}{l}\text { Continuar }+ \text { gerúndio / a }+ \text { infinitivo / } \\
\text { particípio / por }+ \text { infinitivo } \\
\text { Prosseguir }+ \text { gerúndio } \\
\text { Seguir }+ \text { gerúndio / a + infinitivo }\end{array}$ & $\begin{array}{l}\text { Para a situação expressa pelo verbo prin- } \\
\text { cipal, quer seja S.N., quer seja S.R., com } \\
\text { qualquer flexão verbal. } \\
\text { Seguir = "continuar" }\end{array}$ \\
\hline $\begin{array}{l}\text { Passar / Começar / Principiar }+a+\text { infi- } \\
\text { nitivo } \\
\text { As perífrases de }(1223)\end{array}$ & $\begin{array}{l}\text { Para a S.N. nos pretéritos perfeito e } \\
\text { mais-que-perfeito do indicativo. }\end{array}$ \\
\hline
\end{tabular}

4) Indeterminado

\begin{tabular}{l|l} 
Ser + de + infinitivo & Para a S.R. com qualquer flexão verbal. \\
\hline
\end{tabular}

\section{5) Pontual}

Não há perífrases que marcam o aspecto pontual. 


\section{6) Durativo}

\begin{tabular}{|c|c|}
\hline Ter + particípio (invariável) & $\begin{array}{l}\text { No presente do indicativo com verbos } \\
\text { que indicam situações que não aceitam } \\
\text { descontinuidade e em certos casos com os } \\
\text { verbos de estado e transformativos. }\end{array}$ \\
\hline $\begin{array}{l}\text { Ter }+ \text { objeto }+ \text { particípio (variável) } \\
\text { Estar }+ \text { gerúndio } \\
\text { Estar }+ \text { particípio } \\
\text { Estar }+ \text { a / para / em / por }+ \text { infinitivo }\end{array}$ & Para a S.R. com qualquer flexão verbal. \\
\hline $\begin{array}{l}\text { Ir + gerúndio } \\
\text { Vir + gerúndio }\end{array}$ & Com qualquer flexão verbal. \\
\hline $\begin{array}{l}\text { Ficar }+ \text { gerúndio / a }+ \text { infinitivo / particí- } \\
\text { pio / por }+ \text { infinitivo } \\
\text { Permanecer }+ \text { gerúndio / a }+ \text { infinitivo / } \\
\text { particípio }\end{array}$ & $\begin{array}{l}\text { Com qualquer flexão verbal em que são } \\
\text { possíveis. } \\
\text { Ficar e permanecer = "conservar-se em } \\
\text { determinada situação". }\end{array}$ \\
\hline $\begin{array}{l}\text { Continuar }+ \text { particípio / gerúndio / a }+ \\
\text { infinitivo / por }+ \text { infinitivo } \\
\text { Prosseguir }+ \text { gerúndio } \\
\text { Seguir }+\mathrm{a}+\text { infinitivo / gerúndio }\end{array}$ & $\begin{array}{l}\text { Para a situação expressa pelo verbo prin- } \\
\text { cipal, quer seja S. N. quer seja S. R., com } \\
\text { qualquer flexão verbal. } \\
\text { Seguir = "continuar". }\end{array}$ \\
\hline
\end{tabular}

\section{7) Iterativo}

\begin{tabular}{l|l}
\hline Ter + particípio (invariável) & No presente do indicativo \\
\hline Andar + gerúndio / a + infinitivo & $\begin{array}{l}\text { Com qualquer flexão verbal em que são } \\
\text { possíveis. }\end{array}$ \\
\hline Ficar + gerúndio / a + infinitivo & Ficar é auxiliar, marcando iteração. \\
\hline
\end{tabular}

\section{8) Habitual}

\begin{tabular}{l|l}
\hline $\begin{array}{l}\text { Viver }+ \text { gerúndio } / \mathrm{a}+\text { infinitivo / particípio } \\
\text { Costumar }+ \text { infinitivo }\end{array}$ & $\begin{array}{l}\text { Com qualquer flexão verbal em que são } \\
\text { possíveis. }\end{array}$ \\
\hline Usar + infinitivo & Com qualquer flexão verbal. \\
\hline Ser + de + infinitivo & Para a S.N. com qualquer flexão verbal. \\
\hline
\end{tabular}

\section{9) Perfectivo}

Ter + particípio (invariável)

Haver + particípio

Estar + gerúndio

Estar + a / para / por / em + infinitivo

Estar + particípio

Andar + gerúndio $/ \mathrm{a}+$ infinitivo
Com todas as flexões verbais em que são possíveis, exceto o presente do indicativo, e com qualquer tipo de verbo principal.

Para a S.R., nos pretéritos perfeito e mais-que-perfeito do indicativo.

Nos pretéritos perfeito e mais-que-perfeito do indicativo. 
10) Imperfectivo

\begin{tabular}{|c|c|}
\hline Ter + particípio (invariável) & No presente do indicativo. \\
\hline $\begin{array}{l}\text { Ter }+ \text { objeto }+ \text { particípio (variável) } \\
\text { Estar }+ \text { gerúndio } \\
\text { Estar }+ \text { particípio } \\
\text { Estar }+\mathrm{a} / \text { para } / \text { por } / \text { em }+ \text { infinitivo }\end{array}$ & $\begin{array}{l}\text { Para a S.R., com todas as flexões verbais, } \\
\text { exceto os pretéritos perfeito e mais-que-per- } \\
\text { feito do indicativo. }\end{array}$ \\
\hline $\begin{array}{l}\text { Vir }+ \text { gerúndio } \\
\text { Andar }+ \text { gerúndio } / \mathrm{a}+\text { infinitivo }\end{array}$ & $\begin{array}{l}\text { Com qualquer flexão verbal, exceto os } \\
\text { pretéritos perfeito e mais-que-perfeito do } \\
\text { indicativo. }\end{array}$ \\
\hline Viver + gerúndio / a + infinitivo / particípio & $\begin{array}{l}\text { Com qualquer flexão verbal em que são } \\
\text { possíveis. }\end{array}$ \\
\hline
\end{tabular}

11) Inceptivo

Começar / Principiar /

Passar $+\mathrm{a}+$ infinitivo

As perífrases de (1223)
- Nos presentes do indicativo e subjuntivo (usados em descrições simultâneas) e nos pretéritos imperfeitos do indicativo e do subjuntivo (com presentificador).

- Quando combinadas a "estar + gerúndio", com todas as flexões verbais, exceto os pretéritos perfeito e mais-que-perfeito do indicativo. Obs.: As frases com as perífrases de (1223) são pouco comuns e naturais nestas duas condições.

- Para a S.N., nos futuros do presente, do pretérito e do subjuntivo; nas formas de sentido futuro do presente e do pretérito imperfeito do indicativo e do subjuntivo e nos pretéritos perfeito e mais-que-perfeito do indicativo, se houver um elemento adverbial que precisa $o$ momento do início da situação. Obs.: Nestas condições, as frases com as perífrases de passar são pouco comuns.

\section{2) Cursivo}

\begin{tabular}{|c|c|}
\hline $\begin{array}{l}\text { Ter }+ \text { objeto }+ \text { particípio (variável) } \\
\text { Estar }+ \text { gerúndio } \\
\text { Estar }+ \text { particípio } \\
\text { Estar }+\mathrm{a} / \text { para } / \text { por } / \text { em }+ \text { infinitivo }\end{array}$ & $\begin{array}{l}\text { Para a S.R., com qualquer flexão verbal, } \\
\text { exceto os pretéritos perfeito e mais-que-per- } \\
\text { feito do indicativo. }\end{array}$ \\
\hline Vir + gerúndio & $\begin{array}{l}\text { Com qualquer flexão verbal, exceto os } \\
\text { pretéritos perfeito e mais-que-perfeito do } \\
\text { indicativo. }\end{array}$ \\
\hline
\end{tabular}




\section{3) Terminativo}

\begin{tabular}{|c|c|}
\hline $\begin{array}{l}\text { Deixar / Cessar / Parar / Acabar / Terminar } \\
+ \text { de }+ \text { infinitivo }\end{array}$ & $\begin{array}{l}\text { Quando combinadas a "estar + gerúndio", } \\
\text { com todas as flexões verbais, exceto os } \\
\text { pretéritos perfeito e mais-que-perfeito do } \\
\text { indicativo. }\end{array}$ \\
\hline Terminar $/$ Acabar + de + infinitivo & $\begin{array}{l}\text { Nos presentes do indicativo e do subjuntivo } \\
\text { (usados em descrições simultâneas) e nos } \\
\text { pretéritos imperfeitos do indicativo e do } \\
\text { subjuntivo (com presentificador). }\end{array}$ \\
\hline $\begin{array}{l}\text { Deixar / Cessar / Parar / Acabar / Terminar } \\
+ \text { de }+ \text { infinitivo }\end{array}$ & $\begin{array}{l}\text { Para a S.N., nos futuros do presente, do } \\
\text { pretérito e do subjuntivo; nas formas de } \\
\text { sentido futuro dos presentes e dos pretéritos } \\
\text { imperfeitos do indicativo e do subjuntivo; e } \\
\text { nos pretéritos perfeito e mais-que-perfeito } \\
\text { do indicativo, se houver um elemento ad- } \\
\text { verbial que precisa o momento de término } \\
\text { da situação. }\end{array}$ \\
\hline
\end{tabular}

Como se pode observar pelas condições explicitadas, nem sempre a perífrase marca o aspecto sozinha. É preciso deixar claro também que há sempre alguma diferença entre as perífrases que marcam o mesmo aspecto (cf. item 8.16).

No estudo da expressão do aspecto pelo semantema, vimos que os tipos de verbos que mais influenciam no aspecto expresso por recursos tais como as flexões verbais e as perífrases são:

a. os verbos télicos e atélicos;

b. os verbos de situação dinâmica (processos e eventos) e verbos de situação estática (principalmente os de estado),

de modo mais geral. De modo mais restrito, temos a influência de verbos indicadores de situações que não aceitam descontinuidade e de verbos transformativos. Os casos específicos de atuação destes verbos, que seria longo enumerar em uma conclusão, podem ser vistos principalmente nos capítulos 7 e 8 e também no item 9.1, além de em alguns pontos da primeira parte.

Vimos que vários verbos marcam aspecto pelo seu semantema, caso em que não indicam situações propriamente ditas, funcionando mais como marcadores e suportes de categorias verbais. São eles: estar, andar, viver, costumar, usar, ficar, continuar, prosseguir, acabar, terminar, começar, principiar, iniciar, iniciar-se e ser (cf. quadro VI no item 9.1).

Verificamos também que o fato da situação indicada pelo verbo ser um evento 
(pontual), um processo (durativo), uma situação pontual inceptiva ou terminativa não implica que estes verbos marcam, respectivamente, os aspectos pontual, durativo, inceptivo e terminativo pelo seu semantema.

Os adjuntos adverbiais envolvidos na expressão do aspecto em Português exercem sempre uma de três funções:

a. evitar ambiguidades;

b. marcar o aspecto por si ou em combinação com outro elemento;

c. reforçar o aspecto expresso por outro elemento, tornando-o mais patente.

Os adjuntos adverbiais atuam na expressão dos seguintes aspectos:

a. iterativo e habitual. Adjuntos adverbiais de frequência, tais como "sempre, muitas vezes, todo dia, aos domingos etc". Estes, por exemplo, evitam a ambiguidade com o pretérito imperfeito do indicativo; reforçam o aspecto com o presente e o pretérito imperfeito do indicativo e do subjuntivo e o marcam com os pretéritos perfeito e mais-que-perfeito do indicativo;

b. durativo. Adjuntos adverbiais de tempo durativo e os indicadores de progressão, que marcam o aspecto com os pretéritos perfeito e maisque-perfeito do indicativo, por exemplo. Com o pretérito imperfeito do indicativo podemos ter adjunto adverbial de tempo pontual, levando à expressão do durativo, por servir de presentificador à situação;

c. acabado. $\mathrm{O}$ adjunto adverbial de tempo e negação "não...mais" que marca o aspecto com várias flexões verbais;

d. inceptivo e terminativo. Adjunto adverbial de tempo pontual que marca o momento de início ou de término da situação, geralmente em combinação com perífrases inceptivas e terminativas nos pretéritos perfeito e mais-que-perfeito do indicativo e em flexões verbais com valor temporal de futuro.

Como se vê, os adjuntos adverbiais que atuam na expressão do aspecto têm sempre algo a ver com TEMPO; pois são adjuntos adverbiais de tempo (durativo ou pontual), de frequência (que de uma certa forma também indicam tempo), indicadores de progressão (que são adjuntos adverbiais de modo com uma implicação temporal) e o Adjunto adverbial "não ... mais" que é uma mistura de tempo e negação. 
Os adjuntos adverbiais também afetam o aspecto, quando tornam télico um verbo atélico (cf. item 3.1).

Outras relações entre aspecto e adjunto adverbial são:

a. os aspectos perfectivo e imperfectivo geralmente condicionam a interpretação que se pode dar ao adjunto adverbial (cf. itens 4.2.3 e 7.3), pois o perfectivo, normalmente, só admite adjuntos adverbiais de tempo completo e determinado e o imperfectivo, adjuntos adverbiais de tempo incompleto e indeterminado, exceto se damos à frase uma interpretação iterativa;

b. há uma seleção entre aspecto durativo e pontual e os adjuntos adverbiais que expressam duração e pontualidade, quando estes indicam o tempo de realização da situação (cf. item 4.2.8). Vimos também que o habitual normalmente requer adjuntos adverbiais de frequência de sentido totalizador (cf. item 2.2.2.1).

O tipo oracional também interfere com o aspecto expresso. As orações podem marcar o aspecto e alterar ou tornar mais patente o aspecto expresso por outro elemento.

A maioria das orações que interferem com o aspecto são orações subordinadas adverbiais temporais, mas também o fazem as orações subordinadas adjetivas, as orações subordinadas adverbiais proporcionais e as coordenadas alternativas ou de sentido alternativo. Abaixo especificamos a forma como cada uma atua.

As subordinadas adverbiais temporais atuam na expressão dos seguintes aspectos:

a) o habitual, quando condicionam a ocorrência da situação da principal cujo verbo aparece no presente ou no pretérito imperfeito do indicativo e do subjuntivo; e também quando reforçam o habitual marcado pelo presente do indicativo;

b) o durativo e o cursivo, quando funcionam como presentificador da situação da principal cujo verbo aparece no pretérito imperfeito do indicativo e do subjuntivo;

c) o durativo que é expresso por elas, quando indicam o tempo de ocorrência da situação da sua principal cujo verbo normalmente aparece nos pretéritos perfeito e mais-que-perfeito do indicativo. Elas podem também reforçar este aspecto, quando ele é expresso por perífrases de aspecto durativo.

As subordinadas adjetivas criam uma tendência para o imperfectivo e o habitual ou indeterminado, facilitando a expressão destes aspectos pelo presente e 
pretérito imperfeito do indicativo e principalmente os do subjuntivo. As reduzidas de gerúndio sempre levam esta forma nominal a marcar os aspectos imperfectivo, cursivo, não acabado e durativo.

As subordinadas adverbiais proporcionais reforçam o durativo expresso por seu verbo e pelo verbo da sua principal, ou levam estes verbos a expressar tal aspecto, marcando-o.

As coordenadas alternativas ou de sentido alternativo levam o verbo à expressão do aspecto iterativo.

Vimos ainda que o provável aspecto atualizado pelo gerúndio depende muito do tipo de oração desenvolvida a que ele corresponde (cf. item 7.8.2).

A repetição do verbo marca o aspecto durativo com diferentes flexões verbais (cf. item 9.5).

A ênfase entonacional marca o aspecto acabado com os verbos de situação estática e com os verbos atélicos no pretérito imperfeito do indicativo (cf. item 9.6).

Sobre a atuação das preposições na expressão do aspecto (cf. item 9.7). temos os seguintes fatos:

a. em alguns casos, a preposição $\mathbf{A}$ com o infinitivo é a responsável pela atualização dos aspectos imperfectivo, cursivo, não acabado e durativo;

b. em vários casos, pode-se dizer que as preposições usadas na formação de perífrases são as responsáveis ou têm algo a ver com o aspecto expresso pelo todo da perífrase;

c. a preposição POR com o infinitivo é a principal responsável pela atualização do aspecto não começado em Português.

Os complementos do verbo (cf. item 9.8) podem influir no aspecto expresso, na medida em que podem fazer um verbo atélico tornar-se télico, porque, como sabemos, o fato de o verbo ser télico ou atélico pode modificar o aspecto que se atualiza.

Estudamos também a relação do aspecto com as categorias verbais de voz, tempo e modo (modalidade) e chegamos a algumas conclusões, que apresentamos abaixo.

Verificamos que o único aspecto que apresenta restrição com relação à voz é o não começado, que só se atualiza na voz ativa, não aparecendo na passiva e reflexiva. Além disso, vimos que o indeterminado é raro com voz reflexiva (cf. item 10.1). 
$\mathrm{Na}$ relação entre tempo e aspecto (cf. item 10.2) pudemos observar o seguinte:

a. quando temos o presente ou passado, o aspecto se atualiza normalmente, sem qualquer restrição e pela ação de qualquer meio de expressão;

b. o futuro geralmente restringe a atualização dos aspectos, embora futuro e aspecto não sejam de todo incompatíveis. Nenhum aspecto se atualiza no futuro apenas pela ação da flexão temporal. Há sempre a ação de um dos seguintes meios de expressão: perífrases, semantema do verbo, adjuntos adverbiais e a repetição do verbo. Com verbos simples, só há aspecto no futuro, se o verbo é de situação estática ou com a ajuda de adjuntos adverbiais.

Sobre as razões por que o futuro restringe a atualização do aspecto (ver item 10.2), as duas hipóteses mais fortes são o seu valor modal e a realização virtual que ele atribui à situação. Estas duas causas teriam ação conjunta;

a. os aspectos imperfectivo e perfectivo só se atualizam no futuro, se a situação futura for respectivamente presente ou passada em relação a outra situação futura ou em relação a um momento futuro dado;

b. o imperfectivo aparece sempre ligado ao tempo presente que pode ser absoluto ou relativo, pois, se a situação for passada ou futura, teremos sempre um presente relativo;

c. o perfectivo aparece sempre ligado ao tempo passado, exceto quando junto com o pontual no presente. O passado pode ser absoluto ou relativo, pois se a situação for futura, teremos sempre um passado relativo;

d. o cursivo também parece se atualizar apenas quando temos o presente, seja este absoluto ou relativo. Isto, entretanto, pode se dever ao fato de que este aspecto só aparece ao lado do imperfectivo.

A não atualização da categoria de tempo parece implicar também na não atualização do aspecto. Isto porque a não atualização do tempo, geralmente, só ocorre quando há a intenção de se referir apenas à situação em si, sem qualquer referência ao TEMPO envolvido na sua ocorrência.

No estudo da expressão do acabado e não acabado pelos pretéritos imperfeito e perfeito do indicativo (cf. item 7.3), ficou clara uma interferência do sistema temporal no sistema aspectual, pela qual tudo o que é passado tende a ser visto como acabado. 
Na relação entre modalidade e aspecto (cf. item 10.3), verificamos que as modalidades que exigem realização futura para a situação a que se aplicam, ou seja, a prescrição (ordenativa ou aconselhativa), a obrigação, a necessidade, a volição, a intenção, a possibilidade - 1 e a probabilidade - 1 restringem a atualização do aspecto. As que não restringem o aspecto são exatamente as que podem aparecer com situações cuja realização é passada ou presente, isto é, a certeza, a possibilidade - 2 (hipótese) e a probabilidade - 2 (hipótese).

A restrição da modalidade à atualização do aspecto não é total. As perífrases parecem ser o único recurso de expressão capaz de anular ou contornar o efeito da modalidade.

Sobre as causas por que a modalidade restringe a atualização do aspecto (cf. item 10.3), as duas hipóteses mais plausíveis são a exigência de que a situação tenha realização futura e a imperfectividade inerente à noção modal.

É interessante anotar que o Português apresenta a situação mais em seus primeiros ou últimos momentos do que em seu ponto de início ou término e tende a apresentar as situações mais como durativas do que como pontuais. Evidências disso são os fatos de:

a. frequentemente, uma situação pontual ser apresentada como durativa, mas não o contrário;

b. o número de processos ser muito maior que o de eventos e de não haver estados pontuais;

c. os recursos de expressão do aspecto pontual são muito poucos, em comparação com os recursos de expressão do durativo;

d. a frequência de atualização do durativo ser muito maior que a do pontual que seria quase nula.

Dos casos de agramaticalidade ou de inaceitabilidade de frases devidos a problemas ligados ao aspecto, destacaremos apenas um nesta conclusão, por ser ele bastante geral. As perífrases com sentido iterativo sempre formam frases ruins, quando se tem verbos de evento que indicam situações que não se repetem para o mesmo ser, e o sujeito (se o verbo é intransitivo) ou o objeto (se o verbo é transitivo) forem singulares e de sentido não genérico. Como vimos no desenvolvimento deste trabalho, há outros casos de agramaticalidade e inaceitabilidade de frases devidos ao aspecto, que deve, portanto, ser levado em conta quando tratamos do porquê da agramaticalidade e inaceitabilidade de frases portuguesas. 
Deve-se considerar ainda que o aspecto é uma categoria da situação como um todo, donde ele ser influenciado por elementos tão diversos, não só dentro da frase como também fora dela. Todavia isto não implica considerar o aspecto como não sendo uma categoria do verbo, pois é nele que o aspecto se atualiza, mesmo quando não é ele que expressa a situação, ou quando elementos fora dele contribuem para a atualização do aspecto.

Tendo feito um balanço das contribuições de nosso trabalho ao estudo do aspecto verbal, gostaríamos de lembrar alguns pontos cujo estudo seria de interesse para futuros trabalhos. São eles:

a. a questão do aspecto nos nomes a que já aludimos anteriormente nesta conclusão;

b. o estudo, de modo particular, da relação entre aspecto e adjunto adverbial, verificando em que medida um condiciona o outro, e buscando determinar se há outros casos de seleção entre eles, além dos que já apontamos em nosso trabalho;

c. a questão do aspecto expresso pelo subjuntivo em casos que envolvem problemas de interpretação, como os que levantamos em torno dos exemplos (580), (587) e (589);

d. o estudo detalhado das diferenças entre perífrases que expressam o mesmo aspecto;

e. o estudo particular das possibilidades de expressão dos aspectos pelas combinações de perífrases;

f. a resolução da questão que levantamos em 10.3 , sobre se o futuro restringe a atualização do aspecto pelo seu valor modal ou se a modalidade é que restringe o aspecto pelo valor de futuro que atribui às situações. Deve-se considerar ainda a hipótese de que os dois contribuem com parcelas distintas na restrição da atualização do aspecto, agindo conjuntamente;

g. o estudo de um ponto que nos foi sugerido pelo Prof. Milton José Pinto, mas que, infelizmente, não pudemos fazer neste nosso trabalho: verificar se as noções aspectuais são pressuposições ou informação nova dos enunciados. 


\section{ApÊNDICE}

\section{Questionário de pesquisa 1}

Responda aos itens abaixo seguindo as instruções e sem se preocupar com questões de certo ou errado, pois o que interessa neste questionário é saber como você, falante da Língua Portuguesa, sente determinados fatos da língua.

VII) Em cada par de frases abaixo assinale, colocando um círculo, aquela em que a situação expressa é apresentada como algo acabado, que não ocorre, que não está mais em realização no momento em que se fala.

OBS. - Se em algum caso você achar que ambas as frases se enquadram nas especificações acima, assinale a que mais expressa o que especificamos e sublinhe a outra. Se nenhuma se enquadra, não faça marca alguma.

1) a - José limpava a casa.

b - José limpou a casa.

2) a - Paulo falava de você.

b - Paulo falava de você, quando entrei na sala.

3) a - Papai plantava flores ao redor da casa.

b - Papai sempre plantava flores ao redor da casa.

4) a - Roberto lia o livro.

b - Roberto leu o livro. 
5) a - Jorge mergulhava na piscina.

b - Jorge mergulhou na piscina.

6) a - Sérgio escrevia um livro.

b - Sérgio escreveu um livro.

VIII) Assinale a frase que expressa:

OBS. - Se nenhuma frase expressar o indicado, não assinale nenhuma; se ambas expressarem, assinale ambas, mas só o faça se realmente as duas expressarem o que se especificou.

1 - Que a pessoa não mais luta bem.

a) Pedro lutava bem.

b) Pedro lutou bem.

2 - $\quad$ Que a pessoa não mais está fazendo uma cadeira.

a) Élio fazia uma cadeira.

b) Élio fez uma cadeira.

3 - Que a pessoa não mais emoldura quadros.

a) Fábio emoldurava quadros.

b) Fábio emoldurou quadros.

4 - Que a pessoa não mais caminha pelo bosque.

a) Marina caminhava pelo bosque.

b) Marina sempre caminhava pelo bosque.

5 - Que a pessoa não mais poda plantas.

a) Celso podava plantas.

b) Celso podava plantas, quando ouviu o estouro.

6 - Que os trabalhadores não mais partem de manhã.

a) Os trabalhadores partiam de manhã.

b) Os trabalhadores partiram de manhã. 
IX) Marque a alternativa que indica algo que se pode dizer a partir da frase apresentada.

1 - Mário cantou.

a) Mário não canta mais.

b) Maria ainda canta.

c) A frase não dá elementos para se dizer se Mário ainda canta ou se não canta mais.

2 - Tereza arrumava os livros na estante.

a) Tereza não arruma mais os livros na estante.

b) Tereza ainda arruma os livros na estante.

c) A frase não dá elementos para se dizer se Tereza ainda arruma os livros na estante ou não arruma mais.

3 - Cláudia passeou pela praia.

a) Cláudia não está mais passeando pela praia.

b) Cláudia ainda está passeando pela praia.

c) A frase não dá elementos para se dizer se Cláudia ainda está passeando pela praia ou se não está mais.

4 - $\quad$ Maria fazia a comida.

a) Maria não está mais fazendo a comida.

b) Maria ainda está fazendo a comida.

c) A frase não dá elementos para se dizer se Maria ainda está fazendo a comida ou não está mais fazendo a comida.

5 - $\quad$ Augusto pintou a casa.

a) Augusto não está mais pintando a casa.

b) Augusto ainda está pintando a casa.

c) A frase não dá elementos para se dizer se Augusto ainda está pintando a casa ou não está mais.

6 - Os meninos brincaram.

a) Os meninos não estão mais brincando.

b) Os meninos ainda estão brincando.

c) A frase não dá elementos para se dizer se os meninos ainda estão brincando ou se não estão mais brincando. 
O aspecto verbal no Português: a categoria e sua expressão

7 - Selma escreveu a carta.

a) Selma não está mais escrevendo a carta.

b) Selma ainda está escrevendo a carta.

c) A frase não permite dizer se Selma ainda está escrevendo a carta ou se não está mais. 


\section{Questionário de pesquisa 2}

Responda aos itens abaixo seguindo as instruções e sem se preocupar com questões de certo ou errado, pois o que interessa aqui é saber como você, falante da Língua Portuguesa, sente determinados fatos da língua.

X) Em cada par de frases abaixo assinale, colocando um círculo, aquela em que a situação expressa é apresentada como acabada.

OBS. - 1) Se você achar que nenhuma das frases do par se enquadra nas especificações acima, não assinale nenhuma.

2) Se você achar que ambas se enquadram nas especificações, assinale a que mais expressa o que especificamos e sublinhe a outra.

1) a - Célia apagava a luz calmamente.

b - Célia apagava a luz calmamente, quando ouviu chamarem-na.

2) a - José atirava em todo bicho que via.

b - José sempre atirava em todo bicho que via.

3) a - Maria fechava a janela ao anoitecer.

b - Maria sempre fechava a janela ao anoitecer.

4) a - Raul engolia sem mastigar.

b - Raul sempre engolia sem mastigar. 
5) a - Bolivar morria de fome.

b - Bolivar morria de fome, quando o encontraram.

XI) Assinale a frase que expressa:

OBS. - Se nenhuma frase expressar o indicado, não assinale nenhuma; se ambas expressam, assinale ambas; mas só o faça se realmente as duas expressarem o que se especificou.

1 - Que a pessoa acabou de fechar a janela.

a) Maria fechava a janela cuidadosamente.

b) Maria fechava a janela, quando viu um vulto no quintal.

2 - $\quad$ Que a pessoa não mais apaga a luz.

a) Célia apagava a luz ao sair.

b) Célia sempre apagava a luz ao sair.

3 - Que a pessoa não mais pula o muro sem pôr as mãos.

a) $\mathrm{O}$ menino pulava o muro sem pôr as mãos.

b) O menino sempre pulava o muro sem pôr as mãos.

4 - Que a pessoa não mais descobre os erros em poucos minutos.

a) Neste jogo Darci descobria os erros em poucos minutos.

b) Neste jogo Darci sempre descobria os erros em poucos minutos.

5 - $\quad$ Que a pessoa acabou de fazer seu vestido.

a) Tereza fazia seu vestido com carinho.

b) Tereza fazia seu vestido, quando a chamaram do hospital. 


\section{REFERÊNCIAS}

ADRADOS, F. R. El método estrutural y el aspecto verbal. Emerita: Boletin De Linguistica Y Filologia Clasica, Madrid, v.22, p.258-270, 1954.

ALONSO, C. H. Sobre el tiempo en el verbo español. Revista Española de Linguistica, Madrid, v.3, n.1, p.143-178, jan.jun. 1973.

AULETE, F. J. C. Dicionário contemporâneo da língua portuguesa. 3. ed. rev. atual. e aum. Rio de Janeiro: Delta, 1974.

AZEVEDO, M. M. O subjuntivo em português. Petrópolis: Vozes, 1976. 56 p.

AZEVEDO FILHO, L. A. de. Para uma gramática estrutural da língua portuguesa. Rio de Janeiro: Gernasa, 1975.

BALLY, C. Syntaxe de la modalité explicite. Cahiers Ferdinand de Saussure, Geneve, v.2, p.3-13, 1942.

BECHARA, E. Moderna gramática portuguesa. São Paulo: Nacional, 1977.

BERNARDES ARRUDA, V. M. As passivas de estado e de mudança de estado em português contemporâneo. 1978. 130p. Dissertação (Mestrado em Linguística) - Universidade de Brasília, Brasília, DF, 1978.

BONFIM, E. do R. M. Contribuição ao estudo do advérbio. 1976. 90p. Tese (Livre-docência) - Departamento de Letras e Artes, Pontifícia Universidade Católica do Rio de Janeiro, Rio de Janeiro, 1976.

BORBA, F. da S. Pequeno vocabulário de linguística moderna. 2. ed. São Paulo: Nacional, 1976. 149p.

BRANDÃO, Cláudio. Sintaxe clássica portuguesa. Belo Horizonte: Imprensa da Universidade de Minas Gerais, 1963.

BRUGMANN, K. Abrége de grammaire comparée des langues indo européennes. Tradução francesa de J. Bloch. Paris: Klincksieck, 1905. p.521-523.

CÂMARA JUNIOR, J. M. Dicionário de filosofia e gramática referente à língua portuguesa. Rio de Janeiro: J. Ozon, 1974a. 409p.

CÂMARA JUNIOR, J. M. Estrutura da língua portuguesa. Petrópolis: Vozes, 1970. $114 p$. 
CÂMARA JUNIOR, J. M. Princípios de linguística geral. Rio de Janeiro: Acadêmica, 1974b. 333p.

CARRETER, F. L. Diccionário de términos filológicos. 3. ed. Madrid: Gredos, 1974. 460p.

CASTILHO, A. T. de. Introdução ao estudo do aspecto verbal na língua portuguesa. Alfa, Marília, v.12, p.7-135, 1967.

CEGALLA, D. P. Novíssima gramática de língua portuguesa. São Paulo: Nacional, 1976.

COMRIE, B. Aspect: an introduction to the study of verbal aspect and related problems. London: Cambridge University Press, 1976. 142p.

CRETELLA JUNIOR., J. O aspecto e o tempo no sistema verbal. Jornal de Filologia, São Paulo, v.1, n.2, p.135-141, 1953.

CUNHA, C. Gramática do português contemporâneo. Belo Horizonte: B. Álvares, 1972. 510p.

CUNHA, C. F. da. Gramática da língua portuguesa. Rio de Janeiro: FENAME, 1975.

DIAS, A. E. da S. Syntaxe historica portuguesa. Lisboa: Clássica, 1970.

DUBOIS, J. et al. Dicionário de linguística. São Paulo: Cultrix, 1978. 653p.

DUCROT, O.; TODOROV, T. Dicionário enciclopédico das ciências da linguagem. São Paulo: Perspectiva, 1977. 355p.

FERNANDES, F. Dicionário de verbos e regimes. Porto Alegre: Globo, 1965.

FERREIRA, A. B. de H. Novo dicionário da língua portuguesa. Rio de Janeiro: Nova Fronteira, 1975. 1499p.

GARCIA, Luis Cifuentes. Acerca del aspecto. Boletin de Filologia, Chile, t. 8, p.57-63, 1954

GARCIA, O. M. Comunicação em prosa moderna. Rio de Janeiro: Fundação Getúlio Vargas, 1976. 508p.

GOMES NETO, J. O aspecto verbal na literatura de cordel. 1977. Dissertação (Mestrado em Linguística) - Universidade Federal de Santa Catarina, Santa Catarina, 1977.

GRAY, L. H. Foundations of language. New York: Macmillan, 1939.

GUILLAUME, G. Immanence et transcendance dans la categorie du verbe, esquisse d'une théorie psychologique de l'aspect. In: CASSIRER, E. et al. Essais sur le langage. Paris: Éditions de Minuit, 1969. p.207-225.

HERBIG, G. Aktionsart und Zeitstufe. Beitrage zur Funktionslehre des Indogermanischen Verbums. Indogermanische Forschungen, Strassburg, v.6, p.157-269, 1896. 
HOCKETT, C. F. A course in modern linguistics. New York: Macmillan, 1964. $621 \mathrm{p}$.

HOLT, J. Études d'aspect. Acta Jutlandica, Copenhagen, v.15, n.2, p.1-84, 1943.

IMBS, P. L'emploi des temps verbaux en français moderne: essai de grammaire descriptive. Paris: C. Klincksieck, 1960. 272p.

JACOBSOHN, H. Aspektfragen. Indogermanische Forschungen, Strassburg, v.51, p.292-318, 1933.

JOOS, M. The english verb: form and meanings. London: University of Wisconsin Press, 1968. 251p.

LOBATO, L. M. Os verbos auxiliares em português contemporâneo. In: LOBATO, L. M. Análises linguísticas. Petrópolis: Vozes, 1975. p.27-91.

LUFT, C. P. Moderna gramática brasileira. Porto Alegre: Globo, 1976.

LYONS, J. Semantics. Cambridge: Cambridge University Press, 1977. v.2.

MEILLET, A. Linguistique historique et linguistique genérale. 2. Paris: Librairie Honoré Champion, 1972. v.2.

MOIGNET, G. Essai sur le mode subjonctif en latin post: classique et en ancien français. Paris: Alger, 1959.

NIDA, E. A. Morphology: the descriptive analysis of. 2nd. ed. Ann Arbor: The University of Michigan Press, 1949.

OVERDIEP, G. S. Stilistische grammatica van het moderne Nederlandsch. Zwolle: [s.n.], 1937.

PONTES, E. Estrutura do verbo no português coloquial. Petrópolis: Vozes, 1972.

PONTES, E. Verbos auxiliares em português. Petrópolis: Vozes, 1973. 145p.

POTTIER, B. Sur la formulation des modalités en linguistique. Langages, Paris, v.43, p.39-46, sept. 1976.

POUSTMA, H. A grammar of late modern English. II: The parts of speech, section II. The verb and the particles. Groningen: [s.n.], 1926.

QUIRK, R. et al. A grammar of contemporary English. London: Longman Group, 1972. 1120p.

ROCHA LIMA, C. H. da. Gramática normativa da lingua portuguesa. Rio de Janeiro: J. Olympio, 1973. 506p.

ROUSSEL, L. L'aspect en grec attique. Paris: PUF, 1958.

SAID ALI, M. Dificuldades da língua portuguesa. 5. ed. Rio de Janeiro: Acadêmica, 1957. 
SAID ALI, M. Gramática histórica da língua portuguesa. Rio de Janeiro: Acadêmica, 1971. (Biblioteca brasileira de filologia, 19).

SAID ALI, M. Gramática secundária da língua portuguesa. São Paulo: Melhoramentos, 1964. 249p.

VENDRYES, J. Le langage. Paris: La Renaissance du Livre, 1921.

VENTURA, Simões. Reflexões sobre o aspecto verbal. Coimbra: [s.n.], 1921.

VERKUYL, H. J. On the compositional nature of the aspects. Dordrecht: D. Reidel, 1972. (Foundations of language, 15).

WOISETSCHLAEGER, Erich F. A semantic theory of the english auxiliary system. Bloomington: Indiana University Lingustic Club, 1976. p.76. 


\section{INFORMAÇÃO REFERENCIAL}

Tendo em vista o número reduzido de trabalhos que tratam da categoria verbal do aspecto, achamos pertinente elencar aqui alguns trabalhos surgidos após a realização da primeira edição do presente livro em 1981, sem pretensão de exaustividade na listagem.

AZEVEDO, A. M. T. de. Tempo, modo e aspecto verbal na estruturação do discurso narrativo. 1991. Dissertação (Mestrado em Letras) - Faculdade de Letras, Universidade Federal de Minas Gerais, Belo Horizonte, 1991.

CASTILHO, A. T. de. Aspecto verbal no Português falado. In: ABAURRE, M. B. M. e RODRIGUES, A. C. S. (Org.) Gramática do português falado: novos estudos descritivos. Campinas, SP: Unicamp, 2002. v.8, p.83-121.

CARVALHO, M. p.F. de. O aspecto verbal no crioulo caboverdiano. 2001. 176p. Dissertação (Mestrado em Linguística) - Universidade Federal de Minas Gerais, Belo Horizonte, 2001.

COSTA, S. B. B. O aspecto em português. São Paulo: Contexto, 2000.

DOWTY, D. The effects of aspectual class on the temporal structure of discourse: semantics or pragmatics. In: DOWTY, David (Ed.). Linguistics and philosophy. Tense and aspect in discourse. Dordrecht: D. Reidel, 1986. v.9, n.1, p.37-61.

DOWTY, D. (Ed.). Tense and aspect in discourse. Dordrecht: D. Reidel, 1986,

FUCHS, A. Aspecto verbal e dêixis. Cadernos de Estudos Linguísticos, Campinas, n.15, p.87-109, jul./ dez. 1988.

GONÇALVES, C. C. e C. Problemas aspectuais da perifrase estar + gerúndio. 2002.167p. Dissertação (Mestrado em Linguística) - Universidade do Estado de São Paulo, Assis, 2002.

HOPPER, P. J. Aspect and foregrounding in discourse. In: KIMBALL, J. P. (Ed.). Syntax and semantics: discourse and syntax. New York: Academic Press, 1979. v.12, p.213-241.

HOPPER, P. J. (Ed.). Tense-aspect: between semantics and pragmatics. Amsterdam: J. Benjamins, 1982. (Typological studies in language, v.1).

IYANAGA, S. Estudo de aspecto na Língua Portuguesa: análise semântica das perífrases verbais. Tóquio: Universidade de Estudos Estrangeiros de Tóquio, 1980. 
LI, C.; THOMPSON, S. A.; THOMPSON, R. Mc. The discourse motivation for the perfect aspect: the mandarin particle LE. In: HOPPER, P. J. (Ed.). Tense-aspect-between semantics and pragmatics. Amsterdan: J. Benjamins, 1982. p.19-44.

LONGO, B. de O.; CAMPOS, O. de S. A auxiliaridade: perífrases de tempo e de aspecto no Português falado. In: ABAURRE, M. B. M.; RODRIGUES, A. C. S. (Org.). Gramática do português falado: novos estudos descritivos. Campinas, SP: UNICAMP, 2002. v. 8, p.445-477.

LOPES, M. A. G. As categorias verbais de tempo e aspecto no Português: dos valores básicos ao uso. 1987. 101p. Dissertação (Mestrado em Linguística) - Pontifícia Universidade Católica, São Paulo, 1987.

MACACCHERO, N. B. Aquisição das categorias funcionais tempo e aspecto no déficit especificamente linguístico. 2004. 92p. Dissertação (Mestrado em Linguística) - Universidade Federal do Rio de Janeiro, Rio de Janeiro, 2004.

MARTINS, S. R. A expressão do tempo e do aspecto verbal em narrativas escritas infantis. 2002. 127p. Dissertação (Mestrado em Linguística Aplicada) - Pontifícia Universidade Católica, São Paulo, 2002.

SILVA-CORVALÁN, C. Tense and aspect in oral Spanish narrative: context and meaning. Language, Baltimore, v.59, n.4, p.760-780, Dec. 1983.

SMITH, C. S. A speaker-based approach to aspect. In: DOWTY, D. (Ed.). Linguistics and philosophy. Tense and aspect in discourse. Dordrecht: D. Reidel, 1986. n.1, p.97-115.

SMITH, C. S. A theory of aspectual choice. Language, Baltimore, v. 59, n. 3, p.479-501, Sept. 1983.

SOARES, G. de F. Teorias sobre o aspecto verbal: crítica e aplicação ao português e japonês. 1997.134p. Dissertação (Mestrado em Linguística) - Universidade Federal do Paraná, Curitiba, 1997.

SOARES, M. A. B. P. A semântica do aspecto verbal em russo e em português. Rio de Janeiro: Faculdade de Letras, Universidade Federal do Rio de Janeiro, 1987. (Coleção teses).

SOUSA, M. M. F. de. O aspecto verbal nas formas perifrásticas do português oral culto de Fortaleza. 1998. 132p. Dissertação (Mestrado em Linguística) - Universidade Federal do Ceará, Fortaleza, 1998.

TRAVAGLIA, L. C. Um estudo textual-discursivo do verbo no Português do Brasil. 1991. Tese (Doutorado em Linguística) - Instituto de Estudos da Linguagem, Universidade de Campinas, Campinas, 1991. 



\section{Formato $16 \times 23 \mathrm{~cm}$ \\ Tipografia Times New Roman \\ Book Antiqua}


0 verbo é, sem dúvida, a classe de palavras de maior importância para a constituição de frases e textos e, portanto, para a comunicação. Por isso, conhecer suas propriedades e possibilidades significativas é de extrema importância para o uso da língua. Neste livro, com farta exemplicação, você aprenderá muito sobre uma categoria do verbo que é pouco estudada: o ASPECTO. Assim estará apto a exprimir e compreender melhor as nuanças de significação relacionadas com a duração e as fases das situações expressas pelos verbos, bem como as possibilidades de sentido relacionadas a estas noções aspectuais, utilizando melhor a língua na produção e compreensão de textos.

Este livro é de grande interesse para todos que trabalham com texto falado e escrito (professores, jornalistas e outros), para os que se interessam pelo estudo do verbo no Português e, pelas posições tomadas pelo autor na teorização geral sobre 0 aspecto, também para aqueles que pretendem estudar esta categoria em qualquer língua. 